\title{
Geology of the Southern
}

Elkhorn Mountains

Jefferson and Broadwater

Counties, Montana

By M. R. KLEPPER, R. A. WEEKS, and E. T. RUPPEL

GEOLOGICAL SURVEJY PROFESIONAL PAPER 292
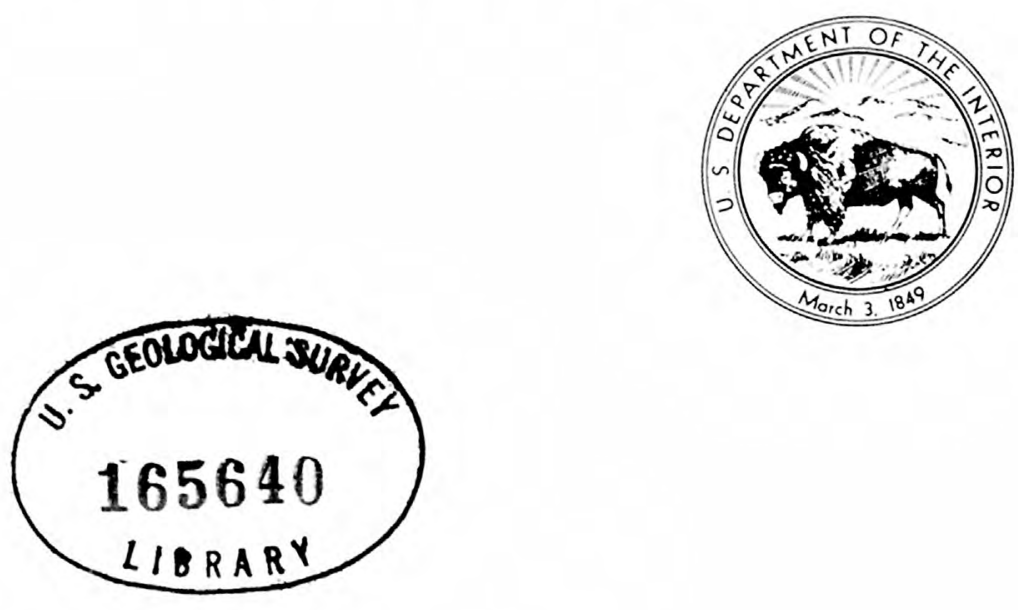


\section{UNITED STATES DEPARTMENT OF THE INTERIOR \\ FRED A. SEATON, Secretary}

\section{GEOLOGICAL SURVEY}

Thomas B. Nolan, Director

For sale by the Superintendent of Documents, U. S. Government Printing Office Washington 25, D. C. - Price $\$ 2.25$ (paper cover) 


\section{CONTENTS}

Abstract Introduction $\ldots \ldots \ldots$ Stratigraphy $\ldots \ldots \ldots \ldots$ Summary . . . . . . Precambrian rocks-Belt series _...

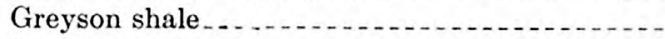
Spokane shale. Empire shale.

Relations of the Spokane shale and the Empire shale

Relations of the Belt series and the Flathead quartzite...

Cambrian system Flathead quartzite

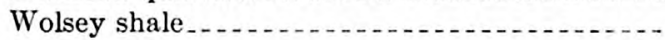
Meagher limestone......... Park shale . . . . . Pilgrim dolomite................................

Devonian and Cambrian systems. ... ............. Maywood and Red Lion formations .........

Devonian system........ Jefferson dolomite . . . . . .

Devonian and Mississippian systems........... Three Forks shale.....

Mississippian system Lodgepole limestone....... Mission Canyon limestone.. . . . . . . . . . .

Mississippian and Pennsylvanian systems _........ Amsden formation . . . . . . . . . . . . . . .

Pennsylvanian system _...

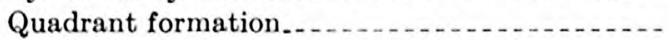

Permian system .......... Phosphoria formation. .......

Jurassic system..... Swift formation Morrison formation.......

Cretaceous system Kootenai formation . . . Colorado formation ..............

Lower black shale unit . . . . Siliceous mudstone and sandstone unit..

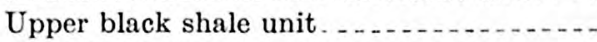

Slim Sam formation ............ Elkhorn Mountains volcanics................. General features.................. Distribution Lithology ... . . . . . . . Age.....

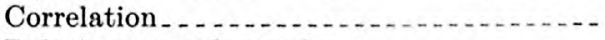
Relations to older rocks. . . .

Tertiary system . . . . . . . .

Oligocene and Miocene(?) tuffaceous sediments and gravel.

Conglomerate of uncertain age . . .......... Rhyolite flow of uncertain age............... Fan deposits and pediment veneers . .........
Stratigraphy-Continued

Quaternary system ......................... 42

Glacial deposits and glaciation........... 43

Landslide deposits ......................... 44

Alluvium . . . . . . . . . . . . . . .

Fan deposits .................... 44

Intrusive rocks . .

Older intrusive rocks. . . . . . . . . . . . . . . . .

Diorite porphyry and related rocks......... 45

Hornblende lamprophyre . . . . . . . . . . 46

Basalt and related rocks................... 46

Younger intrusive rocks . . . .

Stocks near Elkhorn ...................... 46

Black Butte stock ............... 46

Cemetery Ridge stock................ 47

Stock of fine-grained diorite_._._.

Stock of diorite porphyry ............. 48

Turnley Ridge stock............... 48

Rocks of the Boulder batholith .............. 48

Quartz monzonite, granodiorite, and related rocks........... 48

Alaskite, aplite, and related rocks........ 49

Stocks of granodiorite and related rocks....... 50

Composite or hybrid intrusives........... 51

Felsite dikes of uncertain age................ 52

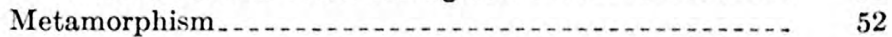

Thermal metamorphism _.

Precambrian rocks.................... 52

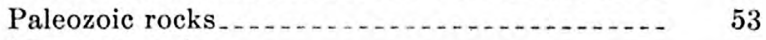

Mesozoic rocks ................... 54

Additive metamorphism . .

Structure ...

Folds_...

Faults...... 56

Early faults......... 56

Faults related to the emplacement of older

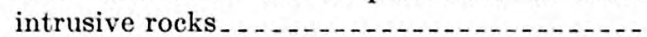

Faults related to the main episode of folding - -

Faults related to the emplacement of younger

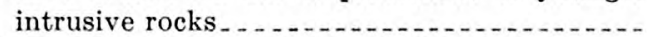

Faults younger than the batholith ..........

Faults of uncertain origin

Tectonic history

Geomorphology.

Regional setting

Lithologic and structural control of topography.....

Evolution of land forms . . . . . . . . .

Metallic mineral deposits

Elkhorn district . . .

Geology

Types of deposits

Replacement deposits in carbonate rocks_.. $\quad 63$

Contact metamorphic deposits............ 64

Pipelike breccia deposits................ 64

Production ........................ 64

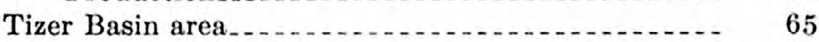


Metallic mineral deposits-Continued

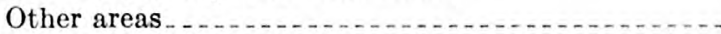

South half of Clancy quadrangle............

North half of Devils Fence quadrangle.......

Southeast part of Devils Fence quadrangle....

Suggestions for prospecting . . . . . . . . . . . . . .

Nonmetallic mineral deposits........................

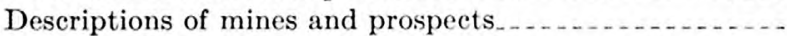

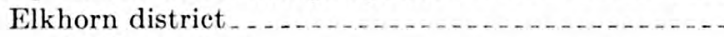

Elkhorn mine .............................

Keene mine .............................

Dolcoath mine and Klondyke mine ..........

Golden Moss mine..........................

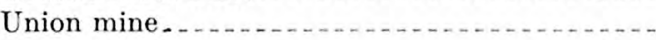

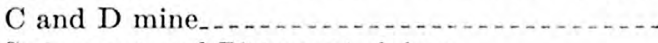

Swissmont and Pittsmont claims ...............

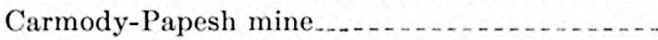

Bulwer and adjacent claims ................

Tourmaline Queen property .................

Skyline mine................

Elkhorn Queen mine ......................

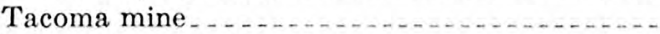

Golden Curry mine.

Page
65
65
65
66
66
66
67
67
67
68
69
69
69
69
69
70
70
70
70
70
72
72

Descriptions of mines and prospects-Continued Elkhorn district-Continued

Elkhorn Peak iron deposits . . . . . . . . . . . . . .

Elkhorn Creek placer.........................

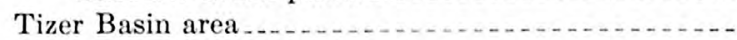

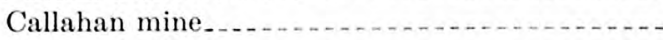

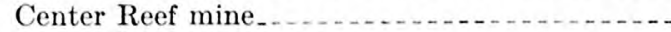

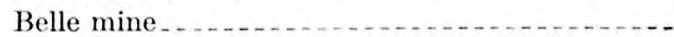

Black Jack claim . . . . . . . .

Wilson Creek and Crow Creek placer deposits.-

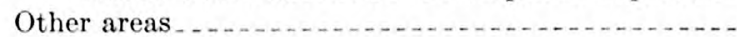

McFadgen-Nave prospect.........................

Katiedid prospect....................................

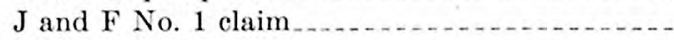

Summit (?) claim .........

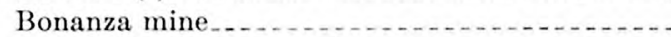

Passover claim . . .

Spar mine . . . . . . . . .

Rothfus iron mine . . . . . .

Parker group....

Ida mine. . . . . . .

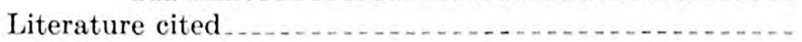

Index . . . .

Page

\section{ILLUSTRATIONS}

[All plates except plate 4 are in pocket]

Plate 1. Geologic map and sections, south half of the Clancy quadrangle, Montana.

2. Geologic map and sections, north half of Devils Fence quadrangle, Montana.

3. Geologic map and sections, southeast part of Devils Fence quadrangle, Montana.

4. A, Relations between Elkhorn Mountains volcanics, Cretaceous sedimentary rocks, and rocks of the Boulder batholith, Elkhorn Peak. B, Broad valley filled with Tertiary volcanic sedimentary rocks

5. Map showing field estimate of metamorphism, Elkhorn mining district, Jefferson County, Mont.

6. Composite map showing Elkhorn, Sophia, and Keene mine workings and surface geochemical anomalies, Elkhorn mining district, Jefferson County, Mont.

7. Map and sections showing fault system of the Callahan mine, Jefferson County, Mont.

8. Composite map and longitudinal projection of workings, Callahan mine, Jefferson Countv, Mont.

Figure 1. Map showing location of the area mapped in the southern Elkhorn Mountains, Broadwater and Jefferson Counties..

2. Index map of west-central Montana showing distribution of andesitic volcanic rocks and related sedimentary rocks of Late Cretaceous and Paleocene age ...

3. Generalized stratigraphic distribution of Late Cretaceous and Paleocene volcanic rocks, west-central Montana

4. Geology of the Skyline mine, Jefferson County, Mont .

5. Geologic map of the Spar mine, Jefferson County, Mont _.

6. Geologic map of the Ida mine, Jefferson County, Mont.

\section{TABLES}

TABLE 1. Chemical analyses of igneous rocks from vicinity of Elkhorn.

2. Chemical analyses of rocks of Boulder batholith near Elkhorn

3. Chemical analyses of rocks from stocks of granodiorite and related rocks and from composite or hybrid plutons.-

4. Quantitative description of rocks from stocks of granodiorite and related rocks .

5. Quantitative description of rocks in composite or hybrid intrusives 


\title{
GEOLOGY OF THE SOUTHERN ELKHORN MOUNTAINS, JEFFERSON AND BROADWATER COUNTIES, MONTANA
}

\author{
By M. R. Klepper, R. A. Weeks, and E. T. Ruppel
}

\begin{abstract}
The geology of an area of about 270 square miles in the southern Elkhorn Mountains, west of Townsend in west-central Montana, is described. The mountains in the southern part of the area comprise northward-trending alternating ridges and valleys underlain principally by folded sedimentary rocks. They merge northward into the higher and more rugged main mass of the mountains, which is underlain principally by upper Cretaceous volcanic rocks. The mountaintops are 1,000 to 4,500 feet above the major valleys.

The sedimentary rocks range in age from Precambrian to Tertiary and the igneous rocks from late Cretaceous to probably middle Tertiary. The oldest rocks are raricolored mudstone, shale, and sandstone of the Belt series of late Precambrian age. They are overlain with slight unconformity by a moderately thick but incomplete section of Paleozoic rocks. The basal Paleozoic formation is the Flathead quartzite of Middle Cambrian age, which is overlain by alternating units of shale and carbonate rock: the Wolsey shale, the Meagher limestone, the Park shale, the Pilgrim dolomite, and the Red Lion formation, all of Cambrian age. A slight erosional unconformity between the Red Lion formation and the Maywood formation of late Devonian age marks a long interval of crustal stability in the area. The Maywood is overlain by the Jefferson dolomite and the Three Forks shale of Late Devonian and Mississippian age, and these in turn are conformably overlain by the Lodgepole and Mission Canyon limestones, a thick carbonate sequence of Mississippian age. A slight erosional unconformity separates the Mission Canyon limestone from the Amsden formation, which probably includes beds of both Mississippian and Pennsylranian age. The Amsden is composed of a heterogeneous assemblage of arenaceous, argillaceous, dolomitic, and calcareous rocks and grades upward into the Quadrant formation of Pennsylvanian age, an alternation of quartzitic sandstone and dolomite. At the top of the Paleozoic section is the Phosphoria formation of Permian age, a thin unit of chert and quartzitic sandstone that contains a few thin phosphate beds.

The basal Mesozoic unit is the Swift formation of late Jurassic age, a thin calcareous marine sandstone that overlies the Phosphoria with slight erosional unconformity. It is overlain by nonmarine shale and sandstone of the Morrison formation of late Jurassic age and the Kootenai formation of Early Cretaceous age. The Kootenai is overlain, possibly with slight erosional unconformity, by the Colorado formation an assemblage of marine dark shale and siliceous mudstone and nonmarine quartz-chert sandstone. The Colorado formation as here used includes beds of both Early and Late Cretaceous age. The Colorado in places grades upwards into a sequence of feldspathic sandstone and tuff beds here named the Slim
\end{abstract}

Sam formation. Elsewhere within the area, the Slim Sam formation is absent, probably in part owing to erosion and in part nondeposition. Where present, the slim Sam grades upward into a thick sequence of andesitic and quartz latitic volcanic rocks, comprising tuffs, lapilli tuffs, breccias, welded tuffs and flows, that are here named the Elkhorn Mountains volcanics and are probably entirely of Cretaceous age. Where the Slim Sam formation is absent, the Elkhorn Mountains volcanics rest with angular unconformity on beds as old as the Morrison.

The pre-Tertiary layered rocks, aggregating more than 15,000 feet in thickness, were folded and intruded by igneous rocks of several types, and the area was uplifted and eroded to a terrain of mature relief, similar to that of the present. During the Oligocene epoch, volcanic sediments with interbreds of nonvolcanic gravel accumulated. These beds were in turn moderately eroded, and gravel of Miocene (?) age was deposited in channels within them. Subsequently, probably during the Pliocene epoch, the Tertiary beds were weakly deformed locally, and a pediment was cut across the Tertiary and older rocks in the southern part of the area. Fan gravel, in part of Recent origin and in part older, blankets parts of the pediment. Glacial deposits of at least two stages of Pleistocene glaciation are present in the higher mountains in the northern part of the area.

The intrusive igneous rocks, except for a few felsite dikes of uncertain age, are divisible into two groups, primarily on the basis of structural relations and secondarily on the basis of composition and fabric. The older group of dioritic and andesitic rocks were intruded in part, if not wholly, prior to the main folding and are similar in chemical and mineralogical composition to the Elkhorn Mountains volcanics. They were probably emplaced throughout the period of volcanism that commenced in late Niobrara time and continued until late Cretaceous time. The younger group consists chiefly of quartzbearing phanerites but includes rocks ranging from gabbro to alaskitic granite and aplite. These rocks were emplaced after the main episode of folding and faulting. The Boulder batholith, composed dominantly of quartz monzonite, is the principal body of this younger group.

The older igneous rocks metamorphosed the invaded rocks only slightly. In contrast, the younger intrusive bodies, and especially the batholith, altered and recrystallized the country rock in moderately broad belts, changing them to various types of hornfels, calesilicate rock, marble, and vitreous quartzite. Concomitantly magnetite, garnet, axinite, and other high-temperature replacement minerals formed locally as products of additive metamorphism.

The pre-Tertiary layered rocks of the southern Elkhorn Mountains are folded into northward-trending folds and are cut by many faults. The sedimentary rocks tend to be more 
tightly folded than the Elkhorn Mountains volcanics, although both were involved in the major folding. The principal folds of the area from east to west are: a major dome, a complex syncline with several second-order folds, and a remnant of a northward-plunging anticline, the major part of which was engulfed by the batholith. The folded rocks are cut by many faults of small to moderate displacement and by two faults of large displacement. Most of the faults were probably formed by the same forces that produced the folds. The origin of the two major faults, however, is uncertain, and may be related to igneous activity. The batholith crosscuts the folded structure and is in turn cut by small faults. Some parts of the area were elevated along steep normal faults in late Tertiary time.

The southern part of the Elkhorn Mountains has been mountainous at least since early Oligocene time, and probably began to take form during the Cretaceous. As a consequence of long continued erosion, the modern topography reflects the structure and lithologic character of the underlying rocks except in a few areas blanketed by poorly consolidated Tertiary rocks and in the higher mountains where glaciation has been prominent.

Silver, lead, zinc, and gold have been produced, either singly or, more typically, as a combination of metals from a number of types of ore deposits. Replacement deposits in carbonate rocks are the most common type, but veins, contact metamorphic deposits, and pipelike bodies of breccia cemented by ore and gangue minerals also are present. The Elkhorn mining district has the largest number of mines and the greatest variety of types of deposits. In the Tizer Basin several narrow goldbearing veins cut andesitic volcanic rocks, and in the southern part of the area sporadic small reins and replacement deposits occur in carbonate rocks. The mines and prospects of the area are described, and some suggestions for future prospecting are outlined. The application of geochemical prospecting techniques may prove of value, judging from the results of reconnaissance soil sampling in the vicinity of the Elkhorn mine.

\section{INTRODUCTION}

The southern part of the Elkhorn Mountains (fig. 1) in western Montana was mapped by the authors during the summers of 1949,1950 , and 1951 as part of a comprehensive study of the geology and mineral deposits in and around the Boulder batholith. The geology of most of the area was plotted on aerial photographs and transferred by Mahan plotter to preliminary 1:24,000 scale topographic maps of the Radersburg 30-minute quadrangle prepared by Fairchild Aerial Surveys, Inc. In some parts of the area the geology was plotted directly on the topographic maps.

The Elkhorn Mountains are bounded on the east by the Townsend Valley, through which the Missouri River flows. To the west the valley of the Boulder River distinctly delimits the southern part of the range, but the northern part of the range merges westward into the Boulder Mountains, from which it is divided, somewhat arbitrarily, by the narrow valley of Beavertown Creek, and, north of the area mapped, by Prickly Pear Creek. The Elkhorn Mountains rise gradually from altitudes of 3,800 to 4,100 feet in the Townsend
Valley and 4,500 to 5,000 feet in the Boulder Valley to crestline altitudes of 7,500 to 9,000 feet. The highest point in the range is Crow Peak at an altitude of 9,414. Although there is abundant water throughout the year in the higher parts of the mountains, only four perennial streams discharge from the area mapped, Crow Creek to the east, and Elkhorn Creek, Muskrat Creek and Prickly Pear Creek to the west. Southern Elkhorn Mountains, as used in this report, includes most of the southern half of the Elkhorn Mountains, and foothills and lowlands south of the range.

The Elkhorn Mountains are girdled by highways and railroads, but no road crosses the main part of the range. Roads follow many creeks and gulches part way into the mountains from both sides, and one county-maintained dirt road crosses from the Townsend Valley to the Boulder Valley through the low hills at the southern end of the range. Principal centers for supply and transportation are Townsend, seat of Broadwater County, on U. S. Highway $10 \mathrm{~N}$. and Helena-Three Forks branch of the Northern Pacific Railway, and Boulder, seat of Jefferson County, on U. S. Highway 91 and the Butte-Great Falls branch of the Great Northern Railway. A few ranches are scattered along the principal valleys in the area mapped. The only settlement within the mountains is the almost abandoned mining camp of Elkhorn, which at present is inhabited by only a few families.

'Reconnaissance geologic studies and investigations of mineral deposits which include parts of the area herein described have been made by a number of geologists. The earliest geologic work in the area was a detailed study by Weed and Barrell (Weed, 1901) of the Elkhorn mine and a small area surrounding it. In 1910 Stone (1911) examined the mineral deposits of the Elkhorn Mountains and made a reconnaissance geologic map that included about two-thirds of the area of the present study. At about the same time Winchell (1914) visited and briefly described the geology and ore deposits of the Radersburg district, most of which lies east of the area mapped in the present study. Knopf's description (1913) of the Helena mining region includes a brief section on the Elkhorn district and provides general information on the regional stratigraphy and petrology. Pardee and Schrader (1933) contribute information on regional stratigraphy, structure and petrology and briefly describe some mineral deposits near Radersburg and Elkhorn. Billingsley's studies (1915 and Billingsley and Grimes, 1918) also furnish information on structual features and ore deposits in and around the Boulder batholith. The occurrence of phosphate rocks in the Elkhorn Mountains has been 
briefly described by Condit, Finch, and Pardee (1928, p. 177-178). Corry's notes (1933) on the gold deposits near Radersburg include a few of the deposits that are in the area of the present report.

Many geologists have contributed ideas or information that has been helpful in this study. The authors are particularly grateful to William A. Cobban and of the U. S. Geological Survey, for fossil identifications, and to Christina L. Balk for suggestions concerning nomenclature and correlation of Upper Cambrian rocks.

The writers are pleased to acknowledge the wholehearted cooperation and hospitality of people in the area. Thanks are due particularly to Wade V. Lewis,

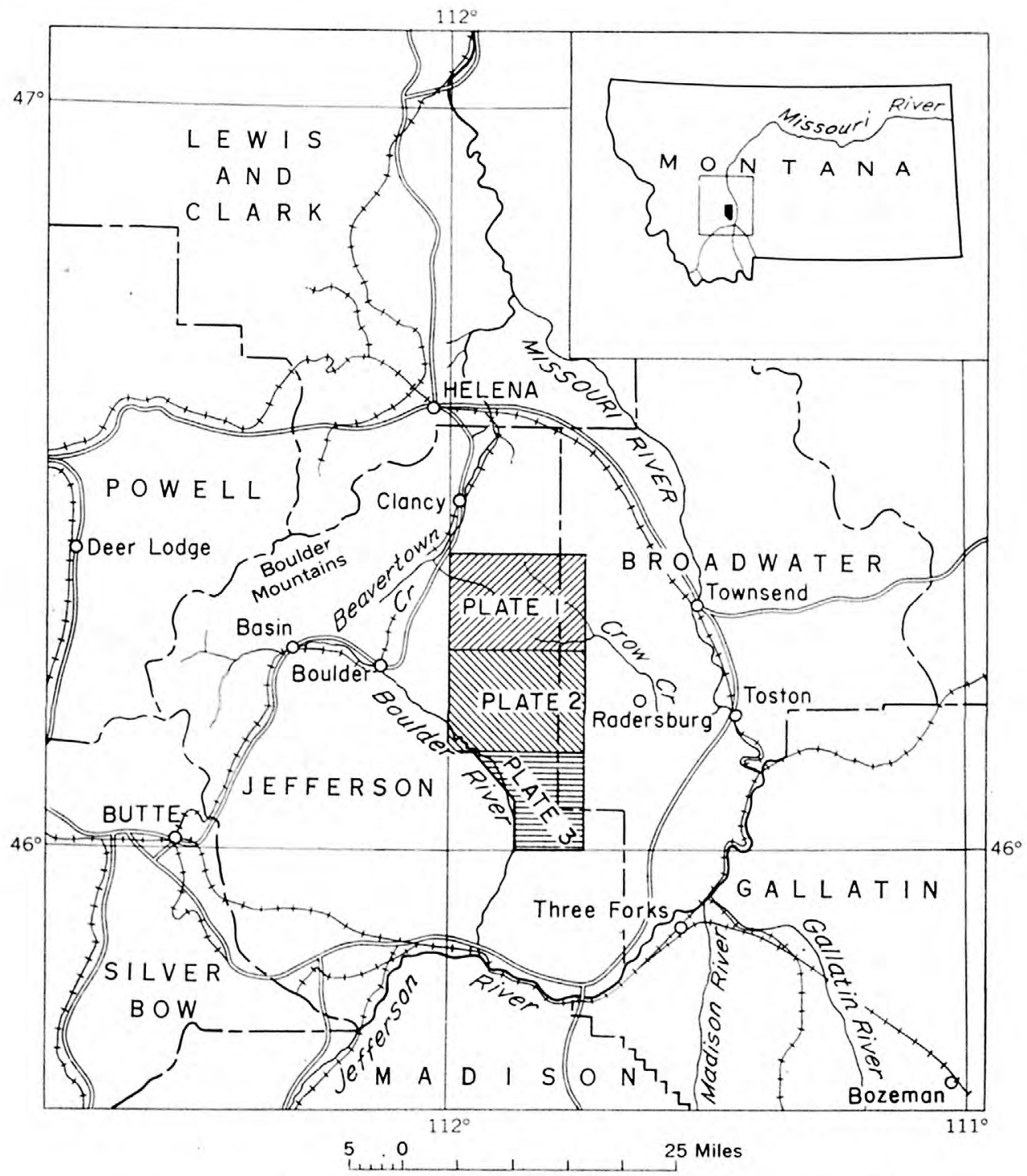

Figuke 1.-Index map showing location of area mapped in the southern Elkhorn Mountains, Broadwater and Jefferson Counties, Mont.

John B. Reeside, Jr. of the U. S. Geological Survey for fossil identifications and ideas concerning the stratigraphy and correlation of the Cretaceous sedimentary rocks, to Adolph and Eleanora Knopf and J. S. Vhay for suggestions concerning problems of igneous geology and volcanic stratigraphy, to James Steele Williams, Allison R. Palmer, Jean Hough, and Ralph Imlay, all
Francis Wickham, the late John Sloss and the late Nat Chamberlin of Boulder, L. T. Carmody and Walter Smith of Elkhorn, I. G. Irving of Butte, and John Rothfus of Helena for maps and other information on mines, and to Alfred Doughty and the late Warren Parker of Radersburg and John Pasini of Boulder for providing field accommodations. 
A. J. Kaufman, Jr., chief, Mineral Industry Division, Region 2, U. S. Bureau of Mines, furnished mine production data from Bureau records. Val L. Freeman, George Simmons, Wayne Roberts, Arthur Berg, and J. W. Hosterman assisted in the field work at various times. L. C. Huff collaborated in reconnaissance geochemical prospecting in the vicinity of the Elkhorn mine.

\section{STRATIGRAPHY}

\section{SUMMARY}

The southern Elkhorn Mountains (plates 1-3) are carved in a thick sequence of sedimentary and layered volcanic rocks that have been folded and faulted, and cut by a variety of intrusive igneous rocks. The oldest rocks exposed are mudstone, shale, and sandstone, which are assigned to the Belt series of the upper Precambrian. (The term mudstone herein refers to nonfissile rocks composed of mud or clay, and the term shale applies only to distinctly fissile rocks composed of mud or clay.) These rocks are overlain, apparently with slight angular unconformity, by the thin but widespread Flathead quartzite of Middle Cambrian age, which in turn is overlain by marine carbonate rocks and shale and sandstone of Cambrian, Devonian, Carboniferous, and Permian age. At least two significant erosional unconformities have been recognized within the Paleozoic sequence, one between the upper Cambrian and Devonian and one within the Mississippian. Resting with slight erosional unconformity on Permian sandstone and chert is a thin Upper Jurassic marine sandstone that is succeeded without recognizable unconformity by nonmarine Upper Jurassic and lower Cretaceous sandstone and shale. The lower Cretaceous rocks are overlain with probable slight erosional unconformity by a thick sequence of alternating nonmarine and marine sandstone, mudstone, and dark-colored shale of Colorado age that grades upward into sandstone and sedimentary tuff, most of which is probably nonmarine. In some localities these rocks grade upward imperceptibly into andesitic volcanic rocks that are probably entirely of Late Cretaceous age; elsewhere a major erosional unconformity, which is almost certainly distinctly angular in some places, separates the sedimentary rocks from the volcanic rocks. A major angular unconformity separates the volcanic rocks from poorly consolidated Oligocene, and possibly Miocene, basin-filling volcanic ash and stream gravel.

Pertinent features of the layered rocks in the southern Elkhorn Mountains are summarized as follows:
Generalized section of geologic formations exposed in the southern Elkhorn Mountains

\begin{tabular}{|c|c|c|c|}
\hline $\begin{array}{l}\text { System or } \\
\text { Series }\end{array}$ & Formation & Lithology & $\begin{array}{c}\text { Thickness } \\
\text { (feet) }\end{array}$ \\
\hline Miocene(?) & Unnamed & $\begin{array}{l}\text { Predominantly poorly consoli- } \\
\text { dated conglomerate. }\end{array}$ & $?$ \\
\hline Oligocene & \multicolumn{2}{|c|}{\begin{tabular}{c|c} 
Unnamed & $\begin{array}{l}\text { Poorly consolidated rhyolitic } \\
\text { tuffaceous siltstone and sand- } \\
\text { stone with sporadic conglom- } \\
\text { erate lenses. }\end{array}$ \\
Strong angular unconformity \\
\end{tabular}} & $0-200+$ \\
\hline \multirow[b]{2}{*}{$\begin{array}{c}\text { Upper } \\
\text { Cretaceous }\end{array}$} & $\begin{array}{l}\text { Elkhorn Moun- } \\
\text { tains volcanics } \\
\text {-Conformity, eros }\end{array}$ & $\begin{array}{l}\text { Predominantly andesitic brec- } \\
\text { cia and quartz latitic welded } \\
\text { tuffs. }\end{array}$ & $5,000+$ \\
\hline & $\begin{array}{l}\text { - Conformity, eros } \\
\text { unconforn } \\
\text { Slim Sam } \\
\text { formation }\end{array}$ & $\begin{array}{l}\text { Sional unconformity, and angular- } \\
\text { nity at different localities } \\
\text { Upper part dominantly green- } \\
\text { ish-gray andesitic sandstone } \\
\text { and sedimentary tuff: lower } \\
\text { part, dominantly nonandesitic } \\
\text { sandstone and siltstone and } \\
\text { some shale. }\end{array}$ & $800-1,200$ \\
\hline $\begin{array}{l}\text { Upper and Lower } \\
\text { Cretaceous }\end{array}$ & $\begin{array}{l}\text { Colorado } \\
\text { formation }\end{array}$ & $\begin{array}{l}\text { Predominantly dark-colored } \\
\text { shale near top and bottom: } \\
\text { light-colored shale, siliceous } \\
\text { mudstone, and chert-bearing } \\
\text { sandstone in middle part. } \\
\text { onal unconformity(?) }\end{array}$ & $1,100-1,500$ \\
\hline $\begin{array}{c}\text { Lower } \\
\text { Cretaceous }\end{array}$ & $\begin{array}{l}\text { Kootenai } \\
\text { formation }\end{array}$ & $\begin{array}{l}\text { Gastropod-bearing limestone } \\
\text { near top; red and green shale } \\
\text { in middle part: "pepper-and- } \\
\text { salt"" sandstone at bottom. }\end{array}$ & $400-650$ \\
\hline \multirow[t]{2}{*}{ Upper Jurassic } & $\begin{array}{l}\text { Morrison } \\
\text { formation }\end{array}$ & $\begin{array}{l}\text { Varicolored shale and sandstone } \\
\text { with sporadic thin limestone } \\
\text { beds. }\end{array}$ & $400-500$ \\
\hline & Swift formation & $\begin{array}{l}\text { Calcareous sandstone with thin } \\
\text { lenses of conglomerate at base. }\end{array}$ & $20-30$ \\
\hline Permian & $\begin{array}{l}\text { Phosphoria } \\
\text { formation }\end{array}$ & $\begin{array}{l}\text { Chert and phosphatic quartzite; } \\
\text { locally contains one or two } \\
\text { thin units of phosphate rock. }\end{array}$ & $40-120$ \\
\hline Pennsylvanian & $\begin{array}{l}\text { Quadrant } \\
\text { formation }\end{array}$ & $\begin{array}{l}\text { Quartzitic sandstone and dolo- } \\
\text { mite. }\end{array}$ & $225-325$ \\
\hline $\begin{array}{c}\text { Pennsylvanian } \\
\text { and } \\
\text { Mississippian }\end{array}$ & $\begin{array}{l}\text { Amsden } \\
\text { formation }\end{array}$ & Red shale and gray dolomite. & $200-300$ \\
\hline \multirow{2}{*}{$\begin{array}{l}\text { Mississippian } \\
\text { (Madison group) }\end{array}$} & $\begin{array}{c}\text { Mission Canyon } \\
\text { limestone }\end{array}$ & Thick-bedded gray limestone. & $800-1,200$ \\
\hline & $\begin{array}{l}\text { Lodgepole } \\
\text { limestone }\end{array}$ & $\begin{array}{l}\text { Thin-bedded bluish-gray lime- } \\
\text { stone. }\end{array}$ & $600-700$ \\
\hline $\begin{array}{l}\text { Mississippian } \\
\text { and Devonian }\end{array}$ & $\begin{array}{l}\text { Three Forks } \\
\text { shale }\end{array}$ & $\begin{array}{l}\text { Drab shale with fossiliferous } \\
\text { limestone unit. }\end{array}$ & $300-375$ \\
\hline Upper Devonian & $\begin{array}{l}\text { Jefferson } \\
\text { dolomite }\end{array}$ & $\begin{array}{l}\text { Dark-gray dolomite and sub- } \\
\text { ordinate limestone. }\end{array}$ & $620-735$ \\
\hline $\begin{array}{l}\text { Upper Devonian } \\
\text { and Upper } \\
\text { Cambrian }\end{array}$ & $\begin{array}{c}\text { Maywood and } \\
\text { Red Lion } \\
\text { formations } \\
\text { undifferentiated } \\
\text { (separated by } \\
\text { erosional uncon- } \\
\text { formity) } \\
\end{array}$ & $\begin{array}{l}\text { Varicolored shale and impure } \\
\text { carbonate rock. }\end{array}$ & $75-135$ \\
\hline $\begin{array}{c}\text { Upper } \\
\text { Cambrian }\end{array}$ & $\begin{array}{c}\text { Pilgrim } \\
\text { dolomite }\end{array}$ & $\begin{array}{l}\text { Gray dolomite and limestone; } \\
\text { in part mottled. }\end{array}$ & $380-510$ \\
\hline \multirow{4}{*}{$\begin{array}{l}\text { Middle } \\
\text { Cambrian }\end{array}$} & Park shale & Green and gray shale. & $200-290$ \\
\hline & $\begin{array}{l}\text { Meagher } \\
\text { limestone }\end{array}$ & $\begin{array}{l}\text { Bluish-gray limestone; in part } \\
\text { mottled. }\end{array}$ & $490-570$ \\
\hline & Wolsey shale & Shale, sandstone, and limestone. & $350-400$ \\
\hline & $\begin{array}{l}\text { Flathead } \\
\text { quartzite }\end{array}$ & Light-colored quartzite. & $100-120$ \\
\hline \multirow{3}{*}{$\begin{array}{c}\text { Precambrian } \\
\text { (Belt series) }\end{array}$} & Empire shale & $\begin{array}{l}\text { Drab siliceous mudstone. Max- } \\
\text { imum. }\end{array}$ & 800 \\
\hline & Spokane shale & $\begin{array}{l}\text { Red mudstone, shale, and sand- } \\
\text { stone. Maximum. }\end{array}$ & 1,700 \\
\hline & Greyson shale & $\begin{array}{l}\text { Gray and brown mudstone, } \\
\text { shale, and sandstone; base not } \\
\text { exposed. }\end{array}$ & 1,500 \\
\hline
\end{tabular}




\section{PRECAMBRIAN ROCKS-BELT SERIES}

In the southern Elkhorn Mountains argillaceous rocks and sandstones of the upper Precambrian Belt series are exposed in the central part of the large domal structure shown on plates 2 and 3 and in a small area southwest of the town of Elkhorn (pl. 1). These rocks aggregate between 3,000 and 4,000 feet in thickness and are separable into three mappable units, primarily on the basis of color. Each unit grades into the adjacent one, and therefore the boundaries shown between them on the geologic map are interpretive.

Rocks of the Belt series are less resistant to weathering than the overlying Paleozoic rocks; consequently, after the domal structure was breached, they were eroded more rapidly than the adjacent Paleozoic rocks and now occupy an elliptical basin within which the relief is relatively low and the topography is more mature and subdued than elsewhere within the mountains. Typically rocks of the Belt series weather to smooth gentle slopes with few outcrops. Even the most resistant beds of quartzitic sandstone and limestone can rarely be traced as far as a mile by discontinuous outcrops and float. Argillaceous beds crop out sporadically in the walls or bottoms of shallow gullies, but are rarely seen elsewhere except as float. In the small area southwest of Elkhorn (pl. 1) the rocks of the Belt series have been thermally metamorphosed to hornstone and quartzite, but even here their outcrop is relatively inconspicuous.

No angular discordance is apparent between rocks of the Belt series and the overlying Flathead quartzite of Middle Cambrian age, but detailed mapping indicates that the Flathead rests upon younger beds at the north end of the area than at the south.

The three mappable Precambrian rock units in the southern Elkhorn Mountains are similar to the Empire shale, the Spokane shale, and the upper part of the Greyson shale of the Belt series in the Big Belt Mountains (Walcott, 1899, p. 206-207; and Mertie, Fischer, and Hobbs 1951, p. 18-20), and in the Spokane Hills (Mertie, Fischer, and Hobbs 1951,) ; consequently, these formation names are used in this report.

A sequence of rocks of the Belt series dissimilar to that described above is exposed along the Jefferson River about 10 miles south of the southernmost exposures in the Elkhorn Mountains (Peale, 1896, Berry, 1943 , p. 5-8; Ross, 1949 , p. 111). This sequence is as much as 5,000 feet thick ${ }^{1}$ and consists predominantly of green to gray coarse-grained clastic rocks that are characterized by poor size sorting of their component fragments, angularity of grains, little or no grain orientation, and an average mineral composition of

${ }^{1}$ Alexander, R. G., Jr., 1951, Geology of the Whitehall area, Montana : unpublished $\mathrm{Ph}$. D. thesis, Princeton Univ.

$408366-57-2$ about 42 percent feldspar, 26 percent quartz, 20 percent micaceous material, 9 percent amphibole and pyroxene, and 1 percent zircon, apatite, sphene, hematite, and garnet $^{1}$. These rocks have been referred to as the North Boulder group by Ross $(1949$, p. 111) and as the La Hood formation by Alexander. They are overlain without noticeable angular discordance by the Flathead quartzite of Middle Cambrian age. According to Sloss (1950, p. 430-431) these coarse sediments of the Belt series intertongue with, and are supplanted to the north by argillite and quartzose sandstone of typically Beltian aspect. Alexander correlates them with the upper 5,000 feet of the Greyson shale in the Whitehall area and with at least the basal part of the Spokane shale east of Three Forks.

\section{GREYSON SHALE}

The Greyson shale, the lowest of the three Belt units exposed in the southern Elkhorn Mountains, is at least 1,500 feet thick and consists of alternations of drab mudstone or shale with light-colored sandstone or quartzite. A few thin beds of limestone occur in the upper part. The base of the formation is not exposed within the area.

The Greyson shale grades into the overlying Spokane shale through a stratigraphic interval of from 50 to 200 feet in which red beds similar to the Spokane are interlayered with beds similar to the Greyson. In the southern part of the area at least two thin beds of limestone occur at or near the base of this transition zone. One of these is oolitic and crossbedded the other is characterized by abundant ellipsoidal or bun-shaped structures that have crude concentric laminations resembling those of the fossil algae Collenia (Fenton and Fenton, 1937, pls. 11-15). Attempts to trace these distinctive beds around the dome failed, probably because they are lenticular and discontinuous. For lack of a key horizon to mark everywhere the contact between the Greyson and Spokane shales, the line was arbitrarily drawn at the bottom of the lowest conspicuous red bed. Poor exposures in this zone increase the difficulty of placing the contact.

\section{SPOKANE SHALE}

The Spokane shale in this area is as much as 1,700 feet thick and consists mainly of soft grayish-red mudstone and shale with fewer beds of sandstone. Locally green or greenish-gray spots, streaks, and beds or groups of beds occur; some, if not all, may have acquired their color by the reduction of originally red-colored iron oxides either by hydrothermal action or by weathering. A few thin beds of limestone are present in the lower part of the formation; at least one of these contains Collenia-like algal structures. The Spokane shale 
grades downward into the Greyson shale and upward into the Empire shale. Where the Empire shale is absent, the Spokane is overlain by the Middle Cambrian Flathead quartzite.

Dark-gray argillite, hornfels, and quartzite formed by thermal metamorphism of shale and sandstone underlie the Flathead quartzite in the complexly intruded area southwest of Elkhorn (pl. 1). Some reddish and purplish beds are present in the lower part of the sequence. Although in mapping, these rocks have been assigned to the Spokane shale, the upper part of the sequence may be Empire shale.

\section{EMPIRE SHALE}

The Empire shale comprises gray, greenish-gray, and brown, distinctly laminated but blocky-fracturing, siliceous mudstone or argillite with subordinate interbeds of quartzitic sandstone and shale. The Empire intertongues with and grades downward into the Spokane. It is overlain by the Middle Cambrian Flathead quartzite.

\section{RELATIONS OF THE SPOKANE SHALE AND THE EMPIRE SHALE}

The Spokane shale and the Empire shale are distinct from one another in both color and lithologic characteristics, but they are at least in part equivalent in age. This is illustrated near the north end of the major dome (pl. 2) where the gray, greenish-gray, and brown Empire tongues out rather abruptly southward into red Spokane. Furthermore, at the north end of the dome 800 feet of Empire shale overlies approximately 1,000 feet of Spokane shale and is overlain by Flathead quartzite, whereas 3 miles southward along the flanks of the dome the Empire shale is absent and the Spokane shale is about 1,700 feet thick and directly overlain by Flathead quartzite. In the intervening area, along the east flank of the dome, red beds intertongue with other strata, and the number and thickness of red beds gradually increase southward to the point of elimination of other strata. These observations indicate that in the southern part of the Elkhorn Mountains the Empire shale is a facies that intertongues with and is equivalent in age to the upper part of the Spokane shale. This relationship is shown somewhat schematically on the geologic map, plate 2 .

\section{RELATIONS OF THE BELT SERIES AND THE FLATHEAD QUARTZITE}

In the southern Elkhorn Mountains rocks of the Belt series are everywhere overlain without obvious angular unconformity by the Middle Cambrian Flathead quartzite. Mapping indicates, however, that an unconformity exists, for at different localities the Flathead is underlain by different types and different thicknesses of rocks of the Belt series. For example, the section between the top of the Greyson shale and the base of the Flathead quartzite is occupied by 1,800 feet of rocks of the Belt series at the north end of the dome; by 1,700 feet of beds 3 miles to the south; and by only 1,200 feet of beds at the south end of the dome, 8 miles farther south.

These observations indicate that the Precambrian section thins southward by 600 feet in a distance of 11 miles. This thinning might be attributed either to nondeposition or to progressively deeper southward truncation by erosion in pre-Flathead time. Deeper truncation southward appears most probable, for in nearby areas an angular discordance has been recognized between rocks of the Belt series and the Flathead quartzite (Deiss, 1935, p. 119-122; Emmons and Calkins, 1913 , p. 50-51; Walcott, 1899 , p. 212). In the Canyon Ferry quadrangle, 30 to 50 miles to the northeast, "the contact of the Flathead with the Belt series . . . is obviously an unconformable one as it truncates the Helena limestone and part of the underlying Empire shale, though at a very low angle." (Mertie, Fischer, and Hobbs, 1951, p. 21.) The abrupt disappearance of the 800 feet of beds of the Empire shale cannot be attributed mainly to truncation, however, for as already pointed out, the gray and brown Empire shale tongues out rather abruptly southward into the red Spokane shale.

\section{CAMBRIAN SYSTEM}

The Cambrian rocks of the southern Elkhorn Mountains are divisible into six distinct lithologic units: a basal quartzite, two alternations of dominantly shaly rocks with limestone or dolomite, and, at the top, a varicolored unit of impure argillaceous and calcareous rocks; the uppermost Cambrian unit is not readily distinguishable from the overlying lowermost Devonian rocks and has been grouped with them to form a satisfactory mapping unit. Some confusion exists concerning the nomenclature and correlation of the Cambrian rocks and rocks immediately overlying them in central and southwestern Montana (Emmons and Calkins, 1913; Deiss, 1936; Sloss and Laird, 1947; Lochman, 1950; Hanson, 1952). The five lowest natural map units in the southern Elkhorn Mountains are lithologically similar to the Flathead sandstone, Wolsey shale, Meagher limestone, Park shale, and Pilgrim dolomite of nearby areas, as redefined by Deiss (1936), and these formational names have been adopted. Limited evidence suggests that these formations in the southern Elkhorn Mountains are also at least approximate, and possibly more precise, faunal equivalents of Deiss' redefined formations. The uppermost Cambrian unit of the southern Elkhorn Mountains clearly resembles the Red Lion formation of the Philipsburg area and the 
overlying Devonian rocks resemble the Maywood formation, which was originally assigned to the Silurian(?) (Emmons and Calkins, 1913, p. 64) but has recently been considered as probably Devonian (Hanson, 1951.) Therefore, the uppermost Cambrian and basal Devonian map unit in the southern Elkhorn Mountains is here designated as Maywood and Red Lion formations undifferentiated.

\section{FLATHEAD QUARTZITE}

The Flathead quartzite forms a low and discontinuous, but nevertheless conspicuous, wooded hogback on the flanks of the large dome in the southern part of the area. It also crops out conspicuously on the flanks of the minor dome which is bisected by Johnny Gulch (pl. 2). Its outcrop in the vicinity of Elkhorn (pl. 1) is relatively inconspicuous. Although the Flathead quartzite is one of the thinnest units mapped, it is the most easily recognized and the best key to structure, for it is lithologically distinctive and crops out more continuously than any other formation. The contact between the Flathead and the underlying Belt rocks can be located within a few feet in many places, but the actual surface of contact was nowhere observed. At many localities attitudes are approximately the same on opposite sides of the contact, indicating that no major angular discordance marks the base of the Cambrian in this area.

The Flathead quartzite is homogeneous, even-grained, medium- to thick-bedded quartz sandstone, with most beds cemented to vitreous quartzite by coalescing overgrowth of quartz on sand grains. Color ranges from white to pale shades of gray, pink, brown, or purple. Thin discontinuous pebble zones are sparsely present throughout the formation but are most common near the base. Crossbedding is prevalent, and in some localities conspicuous. The thickness, measured at three localities within the area and at two in the adjacent Limestone Hills, ranges from 100 to 119 feet. The sections north of the Trail Springs road and in the Limestone Hills, a few miles east of the area of this report, are typical.

Seotion of Flathead quartite north of Trail Spring road in NE1/4 sec. $33, T .5$ N., R. $2 \mathrm{~W}$.

Wolsey shale: lower part not exposed.

Flathead quartzite:

7. Quartzite, light-brownish-gray and light-olivegray; weathers light brown; locally speckled with limonite; medium- to coarse-grained, beds 1-18 in thick, in part conspicuously cross bedded; a lighter colored bed similar to those in unit 1 is at top

6. Covered interval

5. Quartzite; similar to unit 1

4. Covered interval
Flathead quartzite-Continued

3. Sandstone, quartzitic, in part faintly laminated, medium- to coarse-grained; weathers light brown

2. Covered interval

1. Quartzite, very light gray, pinkish-gray, yellowishgray and grayish-orange-pink; in part distinctly color banded; beds in lower $40 \mathrm{ft}$ weather to moderate orange pink and very pale orange indistinctly grooved surface; beds in upper $4 \mathrm{ft}$ weather light brown; medium- to coarsegrained; a few pebbly beds $2-18$ in thick throughont

Total thickness of Flathead quartzite______._. 106 Unconformity, not exposed.

Belt series: Spokane shale.

Section of Flathead quartzite in Limestone Hills, SE1/4 sec. 34, T. $\gamma$ N., R. $1 \mathrm{E}$.

Wolsey shale:

Feet

15. Siltstone, medium- to dark-gray, very micaceous, irregularly laminated; laminae range from 0.03 to 0.01 in in thickness; mildly to moderately metamorphosed

Flathead quartzite:

14. Sandstone, grayish-orange-pink, grayish-pink, and pale-red, quartzitic, vitreous, dense, homogeneous, medium-grained; weathers reddish brown, dark yellowish orange, and moderate dark yellowish brown

13. Sandstone, raricolored: light- to medium-gray, pale-red, and grayish-yellow-green, finegrained, thin- and irregular-bedded.......-.

12. Sandstone; similar to unit 14

11. Sandstone, grayish-orange-pink, grayish-pink, and pale-red, silty, thin- and irregular-bedded.

10. Sandstone; similar to unit 14

9. Siltstone, medium-light-gray to medium-gray, thin-bedded; iregular wavy laminae average about 0.05 in in thickness

8. Sandstone, pinkish-gray, quartzitic, dense, homogeneous, medium-grained; weathers reddish brown, dark yellowish orange, and moderate dark yellowish brown

7. Sandstone, grayish-orange-pink, pinkish-gray, and pale-red, quartzitic, dense, homogeneous, medium-grained; conspicuous bedding cracks spaced from 0.3-2 ft, apart; alternating zones of slightly different color and grain size range from less than 1 in to about 3 in in thickness; in part crossbedded on a small scale; weathers reddish brown, very dusky red, and dusky brown

6. Shale, medium-gray, carbonaceous (?), highly micaceous, fissile

5. Sandstone; similar to unit 7

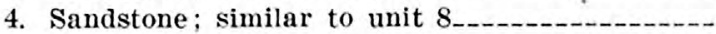

3. Sandstone; similar to unit 7

2. Conglomerate, grayish-pink, grayish-orange-pink, and almost white sandstone matrix with palered, grayish-pink, and almost-white, vitreous rounded quartzite pebbles that range from 0.05 0.25 in in maximum dimension... 1/2

Total thickness of Flathead quartzite

Feet

6

6

$1 / 2$

$1 / 2$

$1 / 2$

Unconformity.

Belt series: 1. Shale, grayish-red, very fissile. Not measured. 
Microscopic examination shows that the typical quartzite consists of well-sorted, subrounded quartz grains with only a few scattered small grains of zircon, tourmaline, and red and black opaque iron oxides. Virtually all of the quartz grains have overgrowths of quartz that are optically continuous with the grains and coalesce to cement the rock into a quartzite. Some of the quartz grains are characterized by sharp and some by undulose extinction. Average grain size in different beds ranges from 0.2 to 0.5 millimeter. The pebble beds consist of a predominant quartzitic sand matrix with from 1 to 50 percent of well-rounded granules and pebbles, as much as 3 or 4 centimeters in maximum dimension, of vein quartz, quartz with undulose extinction, and coarse-grained quartzite.

\section{WOLSEY SHALE}

The Wolsey shale typically occupies a rather narrow swale or valley between a hogback of Flathead quartzite and an equally conspicuous ridge of Meagher limestone. The contact between the Wolsey and Flathead formations was nowhere observed, but at several localities beds of friable brown sandstone and shale crop out within 15 feet above the uppermost ledge of Flathead quartzite, and at one locality a light-colored quartzite bed was seen near the base of the Wolsey. The lower half of the Wolsey consists of greenish-gray and drab shale with some interbeds of sandstone and impure limestone. Many beds are micaceous and some are glauconitic. The upper half of the formation consists of interbedded argillaceous and crudely ribboned or mottled gray limestone and calcareous greenish- and yellowish-gray mudstone or shale. The Wolsey shale grades upward into the Meagher limestone, and the contact is arbitrarily placed at the top of the uppermost conspicuous shale bed. The following measured section is representative.

Section of Wolsey shale north of Trail Spring road in NE1/4 sec. $39, T .5$ N., R. $2 \mathrm{~W}$.

Meagher limestone: finely erystalline ribbon limestone at base.

Wolsey shale:

17. Covered interval

16. Mudstone, calcareous and limestone or dolomite, argillaceous, thin-bedded; weathers yellowish gray and light olive gray; contains thin interbeds of light-gray limestone and edgewise conglomerate of limestone and, in upper half, finegrained micaceous sandstone.

15. Limestone; similar to unit 13 , but in thinner beds

14. Covered interval

13. Limestone, medium-dark-gray, finely crystalline, medium-bedded; ${ }^{3}$ contains conspicuous darkyellowish-gray irregular seams and blotches of silty dolomite

${ }^{1}$ In this report beds as much as 2 or 3 inches are considered to be thin bedded; from 2 or 3 inches to 12 or 18 inches of medium bedded; and more than that, thick bedded.
Wolsey shale - Continued

12. Limestone; similar to unit 13 , but in thinner beds

Feet

11. Limestone, medium-dark-gray to light-gray, thinbedded, coarsely crystalline; contains many partings and thin interbeds of light-olive mudstone and a few thin beds of edgewise conglomerate

10. Siltstone, light-greenish-gray, light-olive, and yellowish-gray, calcareous; beds thin but wavy and lumpy

9. Siltstone, light-brown and yellowish-gray, calcareous, thin- and irregularly bedded

8. Covered interval

7. Limestone; similar to unit 5 .

6. Limestone; similar to unit 5 , but contains interbeds of very fine grained calcareous limonitic sandstone

5. Limestone, silty and sandy, and calcareous mudstone; both weather to very pale orange and grayish-orange ribbed surfaces...............

4. Mostly covered f few outcrops similar to unit 2

3. Limestone, light-olive-gray to greenish-gray, dense, in beds $2-6$ in thick; contains irregular ribbons of yellow silty dolomite

2. Siltstone, dark-yellowish-orange, light-brown, and pale-red; color due to finely dispersed limonite; calcareous, platy to blocky

1. Covered intervals, mostly underlain by drab micaceous siltstone and shale

Total thickness of Wolsey shale

368

Flathead quartzite: Quartzite, light-brownish-gray and light-olive-gray at top.

Locally the Wolsey shale has been invaded by sills of fine-grained diorite porphyry. The sills range from a few feet to about 75 feet in thickness. In some sections three or four sills with an aggregate thickness of at least 100 feet have been observed. Adjacent to the thicker sills the calcareous and argillaceous rocks have been thermally indurated to hard, compact, blockyfracturing argillites.

\section{MEAGHER LIMESTONE}

The Meagher limestone crops out around the major dome and adjacent minor folds in the southern part of the area and near Elkhorn. Typically it forms a ridge somewhat higher but less sharp than that formed by the Flathead quartzite, and lower than that formed by the Pilgrim dolomite.

The Meagher limestone comprises three units; the upper and lower units are similar and distinct from the middle unit. The middle unit consists of mediumgray or medium-bluish-gray, indistinctly thick-bedded limestone. Sporadically distributed within this limestone are thin, irregular ribbons of drab-colored siliceous dolomite that weather out in slight relief. Oolitic beds are common. The upper and lower units are more thinly and more distinctly bedded carbonate 
rocks that are characterized by "black and tan" or "blue and gold" color banding and mottling on weathered surfaces. These color differences reflect differences in lithology. The "blue" or "black" part (most of which is medium gray, $N 5$, or medium dark gray, $N 4$, according to the Rock-Color chart) is relatively pure aphanitic to medium crystalline calcium carbonate. The "tan" or "gold" part (shades of brown, orange and yellow of hues $10 Y R$ and $5 Y$ according to the Rock-Color chart) is very finely crystalline dolomite with a sparse admixture of ferruginous clayey material. The small amount of yellowish dolomite in the gray limestone forms irregular layers ranging from 0.01 to 0.06 foot in thickness and discrete small blebs and more or less interconnected irregular lobate bodies that have the overall appearance of indistinct planarity or ribboning parallel to bedding. All gradations from well-defined planarity, or ribboning, to apparently random dissemination of blebs have been observed.

Measurements at four localities, two within the area and two in the adjacent Limestone Hills, show that the Meagher limestone ranges from 490 to 570 feet in thickness. The three lithologic units can be recognized at each locality, but their distinctiveness varies from place to place. Typically the intermediate unit accounts for about half of the thickness of the formation, and the upper and lower units share the remainder about equally. Representative sections from north of the Trail Spring road and from the Limestone Hills, a few miles east of the area mapped, are given below.

Section of Meagher limestone north of Trail spring road in NE $1 / 4$ sec. $33, T .5 N$., R. $2 W$.

Park shale: lower part covered.

Meagher limestone:

Upper unit:

14. Covered interval; nearby exposures of limestone $2 \mathrm{ft}$ below top of formation contain Glyphaspis sp. and Dorypyge sp. (A. R. Palmer, written communication )

13. Limestone, medium-gray, medium- to thinbedded; weathers medium gray to medium bluish gray; ribboned and irregularly mottled with argillaceous dolomite that weathers yellowish orange.

12. Covered interval

Middle unit:

11. Limestone; similar to that in unit 8 , but with conspicuous moderate-yellow, yellowish-orange, and light-olive-gray siliceous and dolomitic ribbons that in the lower half of the unit are irregular and in the upper half are parallel to bedding

10. Covered interval

9. Limestone; similar to that in unit 8
Meagher limestone-Continued

Middle unit-Continued

8. Limestone; weathers to medium gray or medium bluish gray, rough and pitted, locally blotchy surface; thick bedded or massive, in part medium to coarsely crystalline; in part granular; contains sporadic oölitic beds; greenish-gray and yellowish-gray siliceous and dolomitic ribbons and fretworks occur locally

7. Limestone; similar to unit 8 but contains a few conspicuous narrow bands of yellowish-brown silty dolomite

Lower unit :

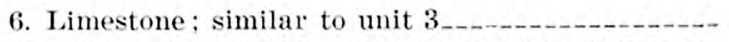

5. Limestone; similar to unit 4 , but ribboning is less conspicuous

4. Limestone; similar to unit 3 but beds are as much as $6 \mathrm{ft}$ thick: wispy yellow silty dolomite ribbons throughout

3. Limestone, typical so-called blue and gold, weathers bluish gray with conspicuous irregular ribbons of moderate-yellow to pale-yellowishorange silty dolomite; in distinct beds as much as $1 \mathrm{ft}$ thick; contains Elrathina sp. and "Ehmania" sp. (A. R. Palmer, written communication ) -

2. Covered interval; float similar to unit 3.......-

1. Limestone, medium-light-gray with irregularly distributed, thin, wispy, yellowish-brown and yellowish-orange siliceous and silty ribbons that weather in slight relief; very finely crystalline; beds are 6-8 in thick; at $15 \mathrm{ft}$ above base contains Dictyonina sp. and unidentified inarticulate brachiopods (A. R. Palmer, written communication)

Total thickness of Meagher limestone

Wolsey shale: upper beds not exposed.

Section of Meagher limestone in Limestome Hills, SW1/4 sec. 34 , T. 7 N., R. $1 \mathrm{E}$.

Park shale:

12. Concealed; underlain by green fissile shale.

Meagher limestone:

Upper unit:

11. Concealed; at least in part underlain by mottled gray and yellowish limestone

10. Limestone, medium-gray, mottled with yellowishorange; gray part of rock is finely crystalline relatively pure $\mathrm{CaCO}_{3}$, and yellowish-orange part is somewhat coarser and is dolomitic; bedding ranges from $0.2-1.5 \mathrm{ft}$ in thickness; weathers light gray mottled with pale yellowish orange.

9. Concealed

Middle unit :

8. Limestone, medium-gray, finely crystalline; irregularly mottled with yellowish-gray dolomitic limestone; some beds contain scattered small chips of limestone that weather in relief.

7. Limestone,' light-gray to medium-light-gray, medium-grained and cross bedded at base; light-gray, sparsely to very oölitic beds with some medium-gray finely crystalline nonoölitic beds in upper part; weathers light gray to medium light gray
Feet

21 
Meagher limestone-Continued

Middle unit-Continued

6. Limestone, medium-gray, very finely crystalline, faintly to conspicuously banded with irregular thin bands of darker, more resistant, probably siliceous limestone; contains twiglike bodies of white calcite; indistinctly thick-bedded; weathers medium gray with local patches of light and medium gray

5. Limestone, medium-dark-gray, banded and mottled with medium-gray dolomitic limestone that weathers in relief

Lower unit:

4. Limestone, medium-gray, mottled with yellowish gray; contains irregular, branching, finely crystalline twiglike bodies of dolomite; most are from $0.02-0.05 \mathrm{ft}$ in length; a few exceed $0.1 \mathrm{ft}$. Weathers to thick slabs

3. Limestone, medium-gray to medium-dark-gray, mottled with dark-yellowish-orange dolomitic limestone that is finely crystalline and occurs in irregular and stringy bodies almost parallel to bedding and ranging from 0.01 to $0.06 \mathrm{ft}$ in thickness; gray portion weathers to yellowish gray or pale yellowish orange

2. Limestone, pale-yellowish-brown to light-olive gray, finely crystalline and dense; contains dark-gray irregular thin bands that weather in relief and probably consist of argillaceous limestone and dolomite; bands are commonly only a few hundredths of a foot thick and separate layers of limestone as much as $0.1 \mathrm{ft}$ thick; limestone weathers medium gray to medium light gray with local spots of pale red and pale yellowish brown to moderate brown; color of unit gradually changes upward to approach that of unit 3

Total thickness of Meagher limestone

Wolsey shale :

1. Mudstone, light-olive-gray, dense, blocky to platy; in irregular beds about $0.04 \mathrm{ft}$ thick; contains a few beds of fine-grained sandstone or coarse siltstone; weathers moderate brown to dark yellowish orange; mildly metamorphosed

\section{PARK SHALE}

The Park shale is the most poorly exposed and consequently the least well known Cambrian formation in the area. It is present on the flanks of the major dome and in adjacent minor structures, where its presence is almost invariably indicated by a gully, narrow valley, or swale between ridges of Meagher limestone and Pilgrim dolomite. Soil formed on the Park shale, if it is not too deeply weathered, contains abundant very small thin chips of somewhat waxy-appearing olive-gray, gray, and light-brown shale. Shale of this type probably forms at least 90 percent of the formation; the remainder consists of thin beds of ribbony argillaceous limestone, siltstone, and silty fine-grained sandstone.
Although the upper and lower contacts of the formation are almost invariably concealed, both must be either sharp or gradational over only a few feet. Measurements of the Park shale at two localities in the southern Elkhorn Mountains and at three in the adjacent Limestone Hills show that it ranges from 200 to 290 feet in thickness. Locally, owing to intrusive sills or to thickening or thinning by deformation, the thickness varies within rather wide limits. The following section describes the best exposures of the formation in the area.

Section of Park shale on north slope of Johnny Gulch in SE $1 / 4$ sec. 17, T. 5 N., R. $1 \mathrm{~W}$.

Pilgrim dolomite: Limestone, pebbly, ölitic, gray at base. Park shale:

12. Covered interval Feet

11. Shale; weathers medium gray and papery 11

10. Argillite, blocky, hard, compact, calcareous _-_-_- 3

9. Andesite sill

8. Covered interval; float is shale similar to unit $7_{--} \quad 24$

7. Shale, papery; weathers light gray and dusky yellow.

6. Limestone, thinly and irregularly bedded; weathers yellowish brown

5. Shale, papery ; weathers light brown

4. Covered by andesite talus

3. Andesite sill.

2. Covered by andesite talus

1. Covered by chips of light-brown, pale-yellowishbrown, and light-olive-gray shale.

Total thickness of Park shale, excluding andesite sills

Meagher limestone: upper beds are medium-gray limestone with grayish-orange mottling.

Like the Wolsey shale, the Park shale is a receptive host to sills of andesite or fine-grained diorite. In some cross sections as many as three sills are present with a total thickness of almost 100 feet. Typically shale within a few inches of these sills is thermally indurated to a hard, compact blocky argillite.

\section{PILGRIM DOLOMITE}

The Pilgrim dolomite forms some of the highest ridges in the central part of the area. It is particularly well exposed around the north half of the dome and in adjacent structures to the east and southwest. Ridges of Pilgrim are typically bordered on one side by a narrow though fairly deep valley or swale eroded in the Park shale and on the other by a narrow shallow depression formed in the Maywood and Red Lion formations. Measurements at two localities in the southern Elkhorn Mountains and two in the adjacent Limestone Hills show that the Pilgrim dolomite ranges from 380 feet to 510 feet in thickness. At each locality a three-fold subdivision of the formation is recognized. 
In the area mapped the lower unit is typically about 50 feet thick and consists principally of mottled lightgray and dark-gray crystalline and oölitic dolomite. In some localities, however, the unit is largely limestone but the overall appearance is the same. The mottling is inconspicuous on fresh fractures but is quite conspicuous on weathered surfaces. In some beds the dark-colored parts of the rock consist almost wholly of aggregates of dark-gray dolomitic (or calcareous) oölites and the light-colored parts are a matrix of finely crystalline very light gray dolomite (or limestone) ; in other beds both light- and dark-colored parts are crystalline dolomite (or limestone). Sporadic intraformational conglomerate beds contain subrounded but predominantly flattened pebbles and granules of darkcolored dolomite (or limestone) imbedded in a matrix of light-colored dolomite (or limestone). Locally intraformational conglomerate beds appear to grade both laterally and vertically into mottled carbonate rock. In most exposures seen the basal 8 or 10 feet of the formation consists of a distinctive bed of bluish-gray pebbly, sandy oölitic limestone that is overlain and underlain by medium bluish-gray limestone irregularly ribboned with yellowish-brown silty dolomite.

The intermediate unit of the Pilgrim dolomite is typically about 175 feet thick and closely resembles the upper and lower parts of the Meagher limestone. It consists of light-gray and medium-gray, crystalline limestone with irregular ribbons of yellowish-gray silty dolomite. Inconspicuous oölitic beds are sporadically present. A. R. Palmer (written communication) identified the following forms found 30 feet above the base of the medial unit in NE $1 / 4$ sec. 36, T. 4 N., R. 2 W. $\mathrm{He}$ considers this fauna to be characteristic of the middle Cedaria subzone.

\section{Arapahoia polita Resser \\ Baltagnostus beltensis Lochman \\ Cedaria n. sp. \\ Kormagnostus esterius Lochman \\ Paracedaria montanensis (Duncan) \\ Semnocephalus centralis (Whitfield) \\ Sysphacheilus dunoriensis (Miller) \\ Dicellomus sp.}

The upper unit of the Pilgrim dolomite ranges from 150 to 225 feet in thickness and consists of light-gray medium-crystalline to sugary dolomite that weathers to a rough cuspate surface of about the same color. Beds are typically between 6 inches and 4 feet thick but rather indistinct; a faint lamination was detected in some. The upper two-thirds of the unit is unusually homogeneous, but at some localities the lower one-third is conspicuously mottled and closely resembles the lower unit of the formation. The unit was probably deposited as a carbonate sand.
The two measured sections that follow are representative of the formation in and immediately to the east of the area mapped.

Section of Pilgrim dolomite on north slope of Johnny Gulch in $S E^{1 / 4}$ sec. $1 \gamma, T .5$ N., R. $1 \mathrm{~W}$.

Red Lion formation: Dolomite, silicified, laminated; 2 -inch bed at base ; is overlain by a 1 -ft bed of yellowishorange shale.

Pilgrim dolomite :

Upper unit :

20. Dolomite, medium coarsely crystalline to sugary, typically in beds $1-4 \mathrm{ft}$ thick ; weathers to lightgray pitted or rippled surface that is uniformly light gray or medium light gray except for sporadic mottling near base

19. Dolomite, medium coarsely crystalline to sugary ; in part oölitic; beds are as much as $3 \mathrm{ft}$, but average about $1 \mathrm{ft}$ thick; most beds weather mottled light and dark gray; a few weather uniformly medium light gray.

18. Covered interval

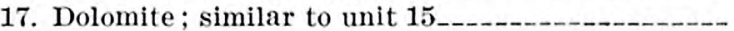

16. Covered interval

15. Dolomite, medium light-gray, medium coarsely crystalline to sugary and oölitic, beds from 2 in to $1 \mathrm{ft}$ thick; a few beds weather mottled medium light and medium dark gray

Middle unit :

14. Covered interval

13. Limestone; weathers light gray and medium gray with inconspicuous yellowish-gray mottling---

12. Covered interval

11. Limestone; similar to unit 6 ; beds are $2-4$ in thick

10. Covered interval

9. Limestone; similar to unit 6 ; beds are from $1 / 2$ in to 6 in thick

8. Covered interval

7. Limestone; similar to unit 6

6. Limestone, finely to medium coarsely crystalline; some beds oölitic; weathers medium dark gray with conspicuous yellowish-gray mottling and closely resembles typical ribboned and mottled limestone beds of Meagher limestone

Feet

Lower unit:

5. Dolomite, light-gray, finely crystalline; grades upward into dark-yellowish-orange dolomitic siltstone.

4. Dolomite, in beds of medium thickness, in part oölitic; weathers mottled light and dark gray --

3. Limestone, medium-bluish-gray with irregularly distributed yellowish-brown and yellowish-red blotches of silty dolomite, dense to finely crystalline

2. Limestone, bluish-gray, pebbly, sandy, oölitic; contains a few thin, yellowish-gray mudstone lenses

1. Limestone, oölitic; weathers bluish gray with irregular yellowish brown streaks parallel to bedding

Total thickness of Pilgrim dolomite 
Section of the Pilgrim dolomite in Limestone Hills SW1/4 sec. 34 , T. 7 N., R. $1 \mathrm{E}$.

Maywood and Red Lion formations:

10. Concealed; in upper $10 \mathrm{ft}$ float is pale-red, palereddish-brown, and moderate-yellowish-brown, chippy to chunky, slightly dolomitic siltstone that weathers light brown, grayish orange pink, and grayish orange; lower $39 \mathrm{ft}$ of unit entirely concealed but probably underlain by similar rock

Pilgrim dolomite:

Upper unit:

9. Dolomite, medium-light-gray to very light gray, medium coarsely crytalline, homogeneous, indistinctly thick-bedded; very indistinctly mottled with various shades of gray in lower part; weathers light gray to very light gray and is characteristically a ridge former

8. Dolomite, medium-gray to medium-dark-gray; finely to medium coarsely crystalline; in part oölitic, irregular, blotchy light-gray mottling parallels or approximately parallels bedding, particularly above the middle of the unit; weathers medium gray to medium dark gray.

Middle unit:

7. Concealed

6. Limestone, medium-light-gray to medium-darkgray, finely crystalline, massive; banded with ribbons of yellowish-gray silty dolomite that form about 30 percent of the total volume of the unit

5. Limestone, medium-light-gray to medium-darkgray, finely crystalline; banded with conspicuous ribbons of pale-yellowish-orange and pale-red silty dolomite that form 30 to 35 percent of the total volume of the unit.

4. Limestone, medium-gray, banded with ribbons of light-brown to dark-yellowish-orange silty dolomite that are about $0.01 \mathrm{ft}$ thick and form less than 10 percent of the total unit near the base; pale yellowish orange dolomite ribbons that are somewhat thicker constitute about 30 percent of the rock near the top.

Lower unit:

3. Limestone, medium-gray with sparsely scattered intraformational chips near the base and with blotchy yellowish-gray ribbons of limestone near the top; unit is transitional into unit 4

2. Limestone, medium-gray to medium-dark-gray, massive; finely cystalline to granular and oölitic; weathers mottled medium gray and medium light gray; mottling parallels bedding in basal $10-15 \mathrm{ft}$ but is blotchy above

Total thickness of the Pilgrim dolomite

Park shale:

1. Concealed; underlain by green, fissile, pencil shale_

\section{DEVONIAN AND CAMBRIAN SYSTEMS}

MAYWOOD AND RED LION FORMATIONS

A sequence of varicolored argillaceous rocks and impure carbonate rocks ranging in thickness from 30 feet to about 200 feet, lies between the Pilgrim dolomite and the Jefferson dolomite in southwestern Montana. These rocks, which until 1947 (Sloss and Laird, 1947) were considered to be wholly of Cambrian age but are now known to be partly of Cambrian and partly of Devonian age, have been given different names by different authors. They are most commonly known as Dry Creek shale. In the Philipsburg quadrangle, 60 miles west of the southern Elkhorn Mountains, these rocks have been divided into two formations, the Red Lion and the Maywood (Emmons and Calkins, 1913). Near Three Forks, about 30 miles southeast of the southern Elkhorn Mountains, Peale (1893) called rocks somewhat similar to those near Philipsburg the Dry Creek shales and pebbly limestone of the Gallatin formation. In the Little Belt Mountains, 60 miles to the northeast, the terms Dry Creek shale and Yogo limestone were used (Weed, 1900). More recently Dorf and Lochman (1940) proposed the names Snowy Range formation and Grove Creek formation for Cambrian rocks between the Pilgrim dolomite and the Jefferson dolomite around the Beartooth Range north of Yellowstone Park. The problem of nomenclature, correlation, and dating of these rocks has been discussed by Deiss (1936), Sloss and Laird (1947), Lochman (1950), and Hansen (1952).

In and adjacent to the southern Elkhorn Mountains a varicolored sequence that consists predominantly of argillaceous rocks in the lower part and predominantly of impure carbonate rocks in the upper part lies between the Pilgrim dolomite and the Jefferson dolomite. In places a distinctive gray limestone with conspicuous thin siliceous laminae is present in the middle part of the unit. This laminated limestone is strikingly similar to the laminated limestone member of the Red Lion formation in the Philipsburg quadrangle (Emmons and Calkins, 1913, pl. X), and the beds above and below the laminated limestone are generally similar to the Maywood formation and the shaly member of the Red Lion formation respectively. Because of these similarities the varicolored rocks of the southern Elkhorn Mountains are referred to the Maywood and Red Lion formations in this report. These two formations were mapped together, however, partly because the total thickness of rock involved is only about 100 feet in most places and partly because the rocks constitute an excellent map unit. In fact, the laminated limestone has been removed from most of the area by pre-Devonian erosion, and in many places where it is absent the unconformity between Cambrian and Devonian rocks cannot be recognized with certainty, partly because of poor exposure and partly because the rocks above and below the unconformity are so similar. 
The Red Lion formation consists predominantly of red and yellowish-brown argillaceous rocks. A distinctive intraformational breccia composed chiefly of large slabs of brown argillite is locally present in the middle part of the formation and in a few places a distinctive gray limestone is present at the top. This limestone is characterized by numerous closely spaced thin siliceous laminae and by the presence of the Upper Cambrian brachiopod Billingsella. The thickness of Upper Cambrian rocks, here referred to the Red Lion formation, ranges from about 30 feet to 95 feet. In part of the Limestone Hills, a few miles to the east, rocks of the Maywood formation appear to rest directly on the Pilgrim limestone (C. Lochman, oral communication), indicating that in some places the full thickness of Red Lion formation was removed by pre-Devonian erosion.

The Maywood formation comprises silty dolomite or dolomitic siltstone with interbeds of shale, limestone, and sandstone. The beds weather light gray, olive gray, yellowish gray, and less commonly, shades of red and orange. The thickness of the Maywood appears to be rather uniformly about 40 feet. Fossils collected from it at two localities establish its age as most probably early late Devonian. Concerning the best collection taken from limestone slide blocks from the upper part of the formation in the NE $1 / 4$ sec. 36, T. 4 N., R. 2 W., G. A. Cooper of the U. S. National Museum writes (written communication, January 5, 1953) :

I am unable to identify the abundant spiriferoid in the collection. The spiriferoid seems to be a Platyrachella. At any rate it is marked on the outside by fine radial lines that cover the entire surface. I have placed such forms in Platyrachella but in some quarters they are placed in Spinocyrtia. Either genus is known in the Middle and early Upper Devonian.

This collection also contains a fine-lined Atrypa like those that occur in the Jefferson limestone and are often erroneously referred to A. missouriensis. The presence of the Atrypa indicates that the rocks enclosing it are probably no younger than Frasnian or low in the Upper Devonian. I incline to this view for the collection but have no evidence other than the type of Atrypa and Spirifer which are rather Upper than Middle Devonian types.

The following section is the best exposed and one of the thickest in the area.

Section of Mayuood and Red Lion formations on north slope of Johnny Gulch in sec. 17, T. 5 N., R, $1 \mathrm{~W}$.

Upper Devonian :

Jefferson dolomite: Dolomite, dark-gray, fetid, well-bedded. Maywood formation :

28. Covered interval ; float is gray-olive, pale-yellowish-brown, and pink thin-bedded calcareous siltstone
Upper Devonian-Continued

Maywood formation-Continued

27. Sandstone, streaked, grayish-white and palebrownish-yellow; weathers light yellowish gray with pinkish blotches; punky, calcareous, finegrained; lower part in beds 1 to 3 in thick; upper $1 \mathrm{ft}$ is one bed

Feet

. Dolomite; weathers pale gray; in beds as much as 6 in thick alternating with yellowish brown and pink laminated dolomitic siltstone and fissile shale

25. Dolomite; weathers grayish white

24. Siltstone; weathers yellowish brown, thin-bedded, in part almost fissile; contains a few 1 -in beds of impure limestone.

23. Dolomite, silty; weathers very light gray; in beds as much as 3 in thick.

22. Shale, calcareous, and argillaceous, thin-bedded to fissile corbonate rock; weathers yellowish brown

21. Dolomite, calcareous, or dolomitic, olive-gray, dense to finely crystalline limestone in beds 1 to 3 in thick; clay lumps common in upper half.

20. Siltstone; weathers pale vellow brown

19. Siltstone, dolomitic, thick and irregularly bedded weathers light gray; most bedding surfaces are coated with brownish clay

18. Covered interval

17. Limestone, light-greenish-gray and olive, argillaceous and dolomitic; weathers yellowish brown; contains scattered crystals and vugs lined with calcite. Fossil collection 49-MRK506, identified as Upper or Middle Devonian by P. E. Cloud (memorandum report)

Total thickness of Maywood formation.

Probable position of erosional unconformity.

Upper Cambrian :

Red Lion formation:

16. Siltstone and shale, pale-brownish-gray, thinbedded to fissile, most beds weakly to moderately calcareous; weathers pale yellow brown with local pink and purple patches_

15. Shale, olive-gray; moderate to strong effervescence with dilute $\mathrm{HCl}$; a 2 -in bed of siltstone at base

14. Siltstone and shale; effervesces moderately; weathers light yellowish brown with local palered blotches.

13. Covered interval

12. Sandstone, punky, fine-grained, slightly calcareous; weathers yellowish brown.

11. Lower $2 \mathrm{ft}$ similar to unit 9 ; upper $5 \mathrm{ft}$ covered except for calcareous sandstone bed near middle

10. Mudstone and shale; weathers purplish red.---

9. Quartzite, grayish-green to pale-pink and paleyellow; weathers pale yellowish brown or rusty brown; laminated in beds as much as 1 in thick

8. Covered interval. 
Upper Cambrian-Continued

Red Lion formation-Continued

7. Shale and laminated siltstone, weathers grayish to purplish red.

6. Covered interval.

5. Siltstone, light-gray and yellowish-brown, laminated in layers as much as $1 / 2$ in thick; moderately effervescent

4. Covered interval

3. Sandstone, argillaceous, beds as much as 1 in thick; weathers reddish brown

2. Covered interval

1. Shale; weathers yellowish brown; contains a few $1 / 2$-in beds of very light yellowish gray dolomitic siltstone; at base is 2-in bed of silicified and laminated dolomite.

Total thickness of Red Lion formation

Pilgrim dolomite: Dolomite, thick-bedded, light-gray.

\section{DEVONIAN SYSTEM}

The Maywood formation is overlain by the Jefferson dolomite, a sequence of dark-colored, fetid dolomite and dolomitic limestone beds, that in turn is overlain by the Three Forks shale of Late Devonian and Mississippian age.

\section{JEFFERSON DOLOMITE}

The Jefferson dolomite is exposed on the flanks of the major dome and in minor folds adjacent to it. It commonly crops out as a ridge somewhat lower than adjacent ridges formed of Pilgrim dolomite and limestones of the Madison group. Even where it does not crop out conspicuously the Jefferson dolomite can readily be traced on the basis of its characteristic blocky dark-gray float. The formation is 730 feet thick where measured on the west side of the dome and 620 feet thick where measured on the east side. At two localities in the nearby Limestone Hills it measures 500 and 640 feet thick.

The Jefferson dolomite is an easily recognized unit that consists almost wholly of dark-gray granularweathering fetid well-bedded dolomite, much of which was deposited as carbonate sand. Dark-gray limestone and medium-gray or light-gray dolomite beds are interlayered throughout, but they are distinctly subordinate. The formation here cannot be subdivided into a lower limestone member and an upper dolomite member as has been done at Three Forks (Sloss and Laird, 1947, p. 1409-1412). Beds typically range from a few inches to a few feet in thickness; many are thinly laminated and some show small-scale channeling and crossbedding. Thin beds of intraformational conglomerate are sporadically present throughout the formation. Small lenses and discontinuous thin layers of chert and partings of yellowish-gray mudstone occur sparingly in the lower half of the formation. Small, apparently discontinuous layers or lenses of dark dolomite breccia, that may not strictly conform to bedding, were seen at a few places, but coarse breccia is not characteristic of the upper 100 feet of the formation as it is at Three Forks (Sloss and Laird, 1947, p. 1409-1411).

Two key units were recognized within the formation. The lower, which is about 35 feet above the base of the formation, is a bed 1 foot thick in which abundant thin (1 millimeter or less), discontinuous, and partly bent and broken layers of finely crystalline white dolomite, that roughly parallel bedding, lie in a "matrix" of medium-gray or dark-gray dolomite of about the same crystallinity. The other is the uppermost 25 to 40 feet of the formation, which every where is light-gray or very light gray faintly mottled dolomite in beds 1 to 3 feet thick.

The following measured section of the Jefferson dolomite is typical for the area.

Section of Jefferson dolomite north of Trail Spring road in $\mathrm{S} 1 / 2$ sec. $28, T .5$ N., R. 2 W.

Three Forks shale: basal beds not exposed.

Jefferson dolomite:

27. Dolomite, medium coarsely crystalline; weathers very light gray to light gray and in part very faintly mottled; in beds 1-3 ft thick; a useful key bed throughout the area.

26. Dolomite, medium- to medium-dark-gray on fresh and weathered surfaces, very finely crystalline, massive, fetid.

25. Covered interval.

24. Dolomite, similar to unit 26

23. Dolomite, similar to unit 26 but weathers to an uncommonly smooth surface.

22. Covered interval.

21. Dolomite, weathers yellowish gray

20. Covered interval

19. Dolomite, medium-dark-gray to medium-gray on fresh and weathered surfaces, finely- to medium coarsely crystalline, fetid, indistinctly bedded; weathers rough and pitted; unit only 50 percent exposed

18. Covered interval

17. Dolomite, similar to unit 19

16. Covered interval

15. Dolomite, similar to unit 19

14. Dolomite; weathers predominantly light gray ; in beds 6 in to $2 \mathrm{ft}$ thick, some of which are distinctly laminated, a few have small-scale channeling and crossbedding; fetid.

13. Dolomite, light-gray; with thin and crinkly laminations

12. Dolomite, finely to medium-coarsely crystalline, thick and inconspicuously bedded, fetid; weathers to medium light-gray to dark-gray rough and pitted surfaces.

11. Covered interval__...

10. Limestone; weathers to medium-light-gray, partly blotchy surface with inconspicuous thin siliceous ribs and fretworks; contains a few yellowish-gray clayey partings.
Feet 31 22 37 
Jefferson dolomite—Continued

9. Limestone, medium-gray to medium-dark-gray on fresh and weathered surfaces, thick and indistinctly bedded, finely to medium-coarsely crystalline, fetid; contains scattered small lenses and a few discontinuous 1-in to 3 -in layers of chert; upper $6 \mathrm{ft}$ weathers light gray

8. Dolomite, closely resembles unit 9 in other respects

7. Concealed interval with $2 \mathrm{ft}$ of light-gray dolomite near middle

6. Dolomite, fetid, massive; weathers medium dark gray

5. Covered interval

4. Dolomite; weathers light gray

3. Dolomite, light- and dark-gray, in thin, crinkly laminae.

2. Dolomite, dark-gray, contains abundant very thin discontinuous and partly bent "layers" of white crystalline dolomite(?) ; a conspicuous unit_-

1. Dolomite, medium-dark-gray to dark-gray on fresh and weathered surfaces, finely crystalline to granular, thickly and indistinctly bedded_-

Total thickness of Jefferson dolomite

Maywood formation: upper beds not exposed.

The Jefferson dolomite appears to be a rather sensitive indicator of intrusive igneous rocks. In at least two localities the distinctive dark color and fetid odor have disappeared as far as 1,500 feet from exposed margins of small intrusive bodies, indicating that organic matter has been driven off. At one locality, within a few hundred feet of the intrusive the formation has been converted to an almost white dolomitic marble; no silicate minerals were observed in this marble.

Evidence pertaining to the age of the Jefferson dolomite was summarized by Berry (1943, p. 10-14.), who concluded that in the Three Forks area the lower 170 feet is upper Middle Devonian and the remainder is Upper Devonian. More recently Sloss and Laird $(1947$, p. 1426) concluded that the formation in the same area is wholly Upper Devonian (upper Senecan and lower Chautauquan), a conclusion that is in harmony with Cooper's opinion about the age of the Maywood fossils (p. 15). Some beds of water-worked fossil debris and a few poorly preserved corals and crinoids were seen in the southern Elkhorn Mountains, but no collections were made.

\section{DEVONIAN AND MISSISSIPPIAN SYSTEMS}

\section{THREE FORKS SHALE}

The Three Forks shale is present in the folded structures of the southern and central part of the area, where it typically occupies broad swales or conspicuous small valleys between ridges of Jefferson dolomite and Lodge- pole and Mission Canyon limestone. The following composite section is believed to be typical:

Top of formation.

Feet

Limestone, silty, siltstone and mudstone, calcareous, and dolomitic; weathers yellowish brown and yellowish orange; near intrusives alters to hard blocky light-gray hornfels

Shale, dark-gray, greenish-gray, and purplish-gray, rarely exposed.

$25-50$

Limestone, gray, fossiliferous, platy and argillaceous near base

$10-25$

Shale, greenish-gray, rarely exposed__________-_ $40-60$

Mudstone, shale, and sandstone, varicolored, in part

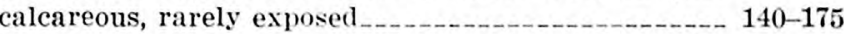

Bottom of formation.

Preston E. Cloud, Jr., reports the following Upper Devonian faunal assemblage from the medial limestone in the NW1/4 sec. 31 , T. 4 N., R. 1 W. (written communication):
Paurorhyncha endlichi (Meek)
Paurorhyncha aff. P. endlichi (Meek)
Cyrtospirifer monticola (Haynes)
Schizophoria cf. immature S. australis Kindle
Ambocoelia sp.
Camarotoechia contracta (Hall)
Camarotoechia sp.
Productella coloradoensis Kindle
Mucrospirifer raymondi (Haynes)
Cyrtospirifer whitneyi animasensis (Girty)
Ambocoelia gregaria Hall
Athyris ef. A. coloradoensis Girty
Athyris sp.
Leiorhynchus madisonense Haynes
Leiorhynchus n. sp. 1
Leiorhynchus n. sp. 2
Straparollus cf. S. clymenioides Hall
Lyriopecten cf. L. fasciatus Hall
Edmondia? sp.
Unidentified bryozoan

Like the shale formations of Cambrian age, the Three Forks shale in places has been thickened and in places thinned by deformation. It also is a receptive host to fine-grained diorite porphyry sills and to small composite or hybrid intrusive bodies. At localities where there is no evidence to suggest thickening or thinning by deformation the formation is 300 to 375 feet thick.

\section{CARBONIFEROUS SYSTEMS}

The Carboniferous systems in the southern Elkhorn Mountains are represented by about 1,700 feet of limestone, a few hundred feet of red and gray argillaceous and dolomitic rocks, and a few hundred feet of interbedded light-colored quartzite and dolomite. The thick limestone is wholly Mississippian and is assigned to the Madison group. The overlying varicolored rocks are assigned to the Amsden formation, which is generally considered to be of both Mississippian and 
Pennsylvanian age (Williams, 1948, p. 329), and the unit of quartzite and dolomite to the Quadrant formation of Pennsylvanian age. For convenience in mapping the Amsden-Quadrant contact has been placed at the top of the red beds, approximately coincident with the appearance of conspicuous beds of quartzitic sandstone. Other investigators (Gardner, Hendricks, Hadley, and Rogers, 1946, p. 4, 12-14, 16-18) in nearby areas appear to have placed the boundary 150 or 200 feet higher and included in the Amsden formation nonred sandstones and dolomites which are here included in the Quadrant. In the southern Elkhorn Mountains upper Mississippian fossils were found within 50 feet of the top of the Amsden formation, as mapped, but no fossils were found higher in the Amsden or in the Quadrant formation.

\section{MISSISSIPPIAN SYSTEM}

\section{MADISON GROUP}

The Madison group consists of a lower unit of thinbedded limestone that grades into an upper unit of thick-bedded limestone. These units were mapped as the Lodgepole limestone and the Mission Canyon limestone following the usage of Collier and Cathcart (1922, p. 173), Sloss and Hamblin (1942, p. 313-324), and others. The Lodgepole and Mission Canyon limestone occupy extensive areas on the north, east, and west flanks of the major domal structure. The Mission Canyon limestone tends to form relatively high and broad ridges bounded in many places by cliffs. The Lodgepole limestone typically underlies moderately steep slopes below the base of cliffs of Mission Canyon limestone and is poorly exposed.

The rocks of both formations tend to recrystallize and lose their most distinctive features in the vicinity of intrusive igneous rocks. The Mission Canyon limestone is especially susceptible, and in a number of places it has been transformed to a coarsely crystalline white or very light gray marble.

\section{LODGEPOLE LIMESTONE}

The Lodgepole limestone is a thin and distinctly bedded medium-gray limestone. Some beds are dense, some are distinctly crystalline, and some are lithified carbonate sand. Among the latter are included beds of water-worn fossil debris. In the lower part of the formation beds range from 1 inch to 1 foot and average 3 or 4 inches in thickness; fossiliferous limestone beds and partings and thin interbeds of yellowish, and rarely reddish, calcareous mudstone are common. The fossiliferous beds characteristically have a fetid odor. In the upper part of the formation beds as much as 2 or 3 feet thick are interspersed with zones of much thinner beds, mudstone partings are rare, fossiliferous beds are less common, and thin siliceous seams and chert lenses occur sporadically. The lower and upper parts of the Lodgepole limestone in this area in some respects resemble and may be approximate equivalents of the Paine and Woodhurst members described by Sloss and Hamblin (1942, p. 313-318, and fig. 8).

The predominantly thinly and distinctly bedded Lodgepole limestone grades upward into the thickly and indistinctly bedded Mission Canyon limestone over an interval of 100 to 200 feet. The boundary is mapped at the top of this transition zone. In Johnny Gulch, (pl. 2) near the eastern part of the area, the formation as thus mapped is 650 feet thick; near the southwestern corner of the area ( $\mathrm{pl} \mathrm{3}$ ) it is 700 feet thick. In some localities, particularly in areas of thermal metamorphism, the formation as mapped is not more than 500 feet thick. The following two sections measured in the Limestone Hills, several miles east of the area mapped, are representative of the Lodgepole limestone in this region.

Section of the Lodgepole limestone at north end of Limestone Hills in SE $1 / 1$ sec. $33, T .7$ N., R. $1 \mathrm{E}$.

[Measured by E. T. Ruppel and M. R. Klepper]

Mississippian :

Mission Canyon limestone (lower part only) :

15. Limestone, medium-light-gray, massive to thick and indistinctly bedded; contains sparse small dark, probably siliceous, rods near base of unit; weathers medium light gray with irregular patches of medium gray _._._._._._._._.

Lodgepole limestone:

14. Concealed; gray, thin-bedded limestone float

13. Limestone, medium-light-gray, medium- to coarse-grained; indistinct beds from 1-2 ft thick; weathers light gray to medium light gray _...

12. Limestone, medium-light-gray, fine-grained in part hackly; in beds $0.2-0.5 \mathrm{ft}$ thick, with yellowish-gray clayey partings; weathers light to medium light gray.

11. Concealed

10. Limestone, medium-light-gray, fine-grained, indistinct beds $0.5-2 \mathrm{ft}$ thick; locally more coarse-grained and fossiliferous; local siliceous encrustations on weathered surface

9. Limestone, medium-gray, fine-grained, sparsely fossiliferous, in beds $0.1-0.3 \mathrm{ft}$ thick; in upper $32 \mathrm{ft}$ beds have a yellowish-gray tint, are separated by clayey partings, and contain scattered thin siliceous encrustations parallel to bedding.

8. Limestone, medium-gray with bluish tint, coarsegrained; in beds $0.5-0.7 \mathrm{ft}$ thick separated by clayey partings
Feet 
Mississippian-Continued

Lodgepole limestone-Continued

7. Limestone, medium-gray with bluish tint, finegrained, fossiliferous; in fairly distinct beds about $0.5 \mathrm{ft}$ thick, with numerous irregular calcite seams and yellowish-gray and pale-red branching clayey partings; contains some medium to coarsely crystalline, very fossiliferous beds in the upper $24 \mathrm{ft}$; bed $4.8 \mathrm{ft}$ thick with very abundant corals and brachiopods occurs from 3.8 to $8.6 \mathrm{ft}$ above the base of the unit

6. Limestone, medium-dark-gray, very fine to finegrained, distinctly bedded in thin to mediumthick beds ; in part thinly laminated ; fossiliferous beds containing horn corals and brachiopods $54.5 \mathrm{ft}$ above base; weathers medium gray with a bluish tint and locally with a yellowish tint; siliceous encrustations on the weathered surfaces of some beds

5 . Sill, granodiorite, $6.5 \mathrm{ft}$ thick.

4. Concealed.

3. Limestone, medium-dark-gray, dense to coarsegrained; lower $4 \mathrm{ft}$ coarse-grained and very fossiliferous; distinctly bedded in beds $0.1-1$ $\mathrm{ft}$ and averaging $0.2-0.4 \mathrm{ft}$ in thickness; in part thinly laminated; in part with a hackly fracture nearly parallel to bedding; weathers medium gray with a bluish and in part a yellowish tint

Total thickness of Lodgepole limestone

Devonian :

Three Forks shale (upper part only) :

2. Sill, granodiorite, $1.6 \mathrm{ft}$ thick.

1. Siltstone, very calcareous, medium-gray, almost fissile

Section of Lodgepole limestone at south end of Limestone Hills in $S W 1 / 4$ sec. $33, T .6$ N., R. $1 \mathrm{E}$.

Mississippian :

[Measured by M. R. Klepper]

Mission Canyon limestone:

35. Limestone, medium-light-gray, massive.

Lodgepole limestone:

34. Concealed.

33. Limestone; weathers gray and bluish gray ; contains irregular pale-yellowish-brown silty laminae.

32. Limestone; weathers gray and bluish gray ; contains pale-red and yellowish laminae

31. Limestone, gray, dense; contains irregular silty laminae spaced $0.1-0.5 \mathrm{ft}$ apart; weathers mottled medium to light gray with a bluish tint; silty laminae weather yellowish gray, grayish yellow, light brownish gray, and pale red......-

30. Concealed.

29. Limestone, bluish gray, dense, and interbedded gray, granular, punky limestone; in beds averaging about $0.3 \mathrm{ft}$ in thickness

28. Concealed.

27. Limestone, gray, granular, punky; contains abundant crinoid fragments

96

Mississippian-Continued

Lodgepole limestone-Continued

26. Concealed; bluish-gray limestone float

Feet

25 . Limestone; weathers gray and bluish gray; contains thin and sparse grayish-yellow to very pale yellowish-orange irregular silty laminae.-

24. Limestone, dense, indistinctly bedded; contains irregular silty laminations; weathers mottled gray and bluish gray.

23. Concealed 


\section{MISSTON CANYON LIMESTONE}

The Mission Canyon limestone is composed of thick and indistinct beds of medium-gray to light-gray crystalline to granular limestone with subordinate thinner and more distinct beds of darker gray limestone near top and bottom. A few thin siliceous layers are present in the lower 200 feet, and sparse gray chert nodules and lentils occur in the upper half. In the central part beds that contain abundant small twiglike bodies of white crystalline calcite are common. The formation closely resembles the Brazer limestone of southeastern Idaho and northeastern Utah in lithology, appearance, and faunal content, and is probably wholly late Mississippian in age in this local area (James Steele Williams, oral communication). Although no sections were measured in detail within the area mapped because of the virtual impossibility of accurately determining minor structures in such a massive rock, the thickness of the formation at all localities appears to be between 800 and 1,200 feet.

The following section of the Mission Canyon limestone measured in the Limestone Hills just east of the map area is considered to be typical of the formation in this region.

Mission Canyon limestone in the Limestone Hills SE1/4 sec. 29, T. $6 \mathrm{~N}, \mathrm{R} .1 \mathrm{E}$.

[Measured by E. T. Ruppel and M. R. Klepper]

Mississippian and Pennsylvanian :

Amsden formation:

42. Concealed ; red siltstone float (basal part only) --

Mississippian :

Mission Canyon limestone:

41. Limestone, medium-gray to medium-light-gray, fine-grained, slightly fetid, massive; sporadic siliceous encrustations on weathered surface; top of unit marked by a bed of limestone breccia $0.2-1 \mathrm{ft}$ thick; unit weathers light gray to medium light gray

40. Breccia, limestone and siltstone fragments in a limestone matrix

39. Concealed

38. Limestone, medium-gray to medium-light-gray, fine-grained, slightly fetid; contains sparse chert lenses and lumps; weathers light gray to medium light gray.

37. Limestone, medium-gray to medium-light-gray, medium-coarse- to coarse-grained, slightly fetid, thick and indistinctly bedded; sparse lumpy siliceous encrustations occur along bedding; weathers to rounded but rough and pitted light-gray to medium-light-gray outcrops

36. Concealed; moderately abundant float chips of yellowish-gray calcareous siltstone; possibly underlain by breccia unit similar to unit $40 \ldots$

Mississippian-Continued

Mission Canyon limestone-Continued

35. Limestone, similar to unit 3$\rceil$ but not siliceous_.-

Feet

32

34. Limestone, medium-light-gray, fine-grained to very fine grained, moderately fetid, massive; contains abundant small, clear crystalline caleite twigs; weathers to very rough patchy surface colored medium light gray and medium light gray with yellowish tint.

33. Limestone, medium-gray to medium-light-gray, medium-coarse- to coarse-grained, slightly fetid; contains three conspicuous chert lenses averaging $0.08 \mathrm{ft}$ in thickness and from 1 to $3 \mathrm{ft}$ apart; unit weathers light gray to medium light gray.

32. Limestone, medium-gray to medium-light-gray, fine- to medium-coarse-grained; weathers medium dark gray

31. Limestone, medium-gray to medium-light-gray, fine-grained, slightly fetid; contains sparsely scattered angular chert fragments; weathers light gray to medium light gray.

30. Limestone, medium-gray to medium-light-gray, fine-grained; contains sparely dispersed irregular small lumps and bands of chert; weathers light gray to medium light gray...--

29. Concealed; probably underlain by limestone breccia

28. Limestone, medium-light-gray to medium-gray, fine- to coarse-grained, slightly fetid; contains irregular lenticular to streaky brownweathering siliceous bands and ribs that roughly parallel bedding and form less than 5 percent of the outcrop surface; weathers light gray to medium light gray

27. Limestone, medium-gray to medium-light-gray, fine-grained, slightly fetid, thick and indistinctly bedded; weathers to rough and pitted surface colored light gray to medium light gray

26. Limestone; similar to unit 28

27

25. Limestone, medium-gray to medium-light-gray, medium-coarse- to coarse-grained slightly fetid, thick and indistinctly bedded; contains some siliceous bands in the upper 10 ft similar to those in unit 28 ; weathers light gray to medium light gray with a rough and pitted surface

24. Limestone; similar to unit 25 , but with irregular siliceous encrustations

6

23. Limestone; similar to unit 25 , but with moderately sparse small bedding lenses and irregular pods of medium-dark-gray chert that weathers dark yellowish brown

22. Limestone, medium-gray to medium-light-gray, fine-grained; contains a few small siliceous encrustations; breccia zone, $3.5 \mathrm{ft}$ thick, occurs 8-11.5 $\mathrm{ft}$ above the base of the unit; weathers to light gray or medium light gray with rough and pitted surface 
Mississippian-Continued

Mission Canyon limestone-Continued

21. Limestone, light-gray, very fine-grained, moderately fetid, massive; small clear crystalline calcite twigs abundant; sparse siliceous encrustations; weathers to patchy, very rough surface colored medium light gray and medium light gray with yellowish tint

20. Concealed

19. Limestone; similar to unit 21 , but without conspicuous calcite "twigs".

18. Concealed

17. Limestone breccia; limestone matrix with subangular to subrounded pebbles as much as 1 inch in maximum dimension of limestone similar to that in unit 22

16. Concealed

15. Limestone, light-gray, very fine-grained, moderately fetid, massive; small clear crystalline calcite "twigs" except in upper $8 \mathrm{ft}$ of unit; weathers to a patchy very rough surface colored medium light gray and medium light gray with yellowish tint

14. Limestone, medium-gray to medium-light gray, medium-coarse- to coarse-grained slightly fetid, thick and indistinctly bedded; weathers to a light-gray to medium-light-gray rough and pitted surface.

13. Limestone; similar to unit 14 , but medium to fine-grained and thick but distinctly bedded.-

12. Concealed

11. Limestone, medium-gray to medium-light-gray, medium-coarse- to coarse-grained slightly fetid, massive; weathers to a patchy very rough surface colored medium light gray and light olive gray -

10. Concealed.

9. Limestone, medium-gray to medium-light-gray, medium- coarse- to coarse-grained slightly fetid, thick and indistinctly bedded; abundant angular fragments of siliceous limestone weather in relief; weathers to a light-gray to mediumlight-gray rough and pitted surface-

8. Limestone, medium-gray to medium-light-gray, fine-grained to coarse-grained, slightly fetid, thick and indistinctly bedded ; contains irregular lenticular to streaky siliceous ribs which roughly parallel bedding; ribs in upper $16 \mathrm{ft}$ of unit are thicker and more continuous, as much as $0.3 \mathrm{ft}$ thick and occurring at intervals of from $0.2-4 \mathrm{ft}$; unit weathers to a light-gray to medium-light-gray rough and pitted surface--

7. Limestone, medium-gray, medium-coarse- to coarse-grained, slightly fetid, thick and indistinctly bedded; weathers to a medium-lightgray rough and pitted surface.

6. Concealed

5. Limestone; similar to unit 7 .

4. Limestone, medium-gray to medium-light-gray, medium-coarse- to coarse-grained, slightly fetid, thick and indistinctly bedded; contains large horn corals about $25 \mathrm{ft}$ above base of unit; weathers to a rough and pitted light-gray to medium-light-gray surface.
Mississippian-Continued

Mission Canyon limestone-Continued

3 . Concealed

2. Limestone, medium-gray to medium-light-gray, coarse-grained, in medium to thick and indistinct beds; locally contains fragments of corals and brachiopods; irregular clayey partings occur in upper 9 feet; weather medium light gray.

Total thickness of Mission Canyon limestone 1,107

Lodgepole limest one (upper bed only) :

1. Limestone, medium-light-gray, thin and indistinctly bedded; contains irregular yellow, lightolive-gray and, less commonly, pale-red clayey partings

The Mission Canyon limestone tends to underlie rolling uplands in which it forms rather inconspicuous low rounded outcrops. At the margins of these uplands the formation is well exposed in steep or vertical bluffs. Weathered surfaces, though similar in appearance, differ in detail. Some beds weather to rough, cuspate surfaces, others to smooth or only slightly roughened or fretted surfaces. Small irregular-shaped siliceous crusts that stand in slight relief above the weathered surface are common, and are easily mistaken for chert. The typical color of weathered surfaces is between light gray and medium gray, but on some surfaces large patches or mottles are light olive gray.

A feature of the Mission Canyon limestone that has been observed elsewhere but only briefly mentioned (Blackstone, 1940, p. 594; Tourtelot and Thompson, $1948 ;$ J. S. Vhay, oral communication), is the presence of one or more beds of breccia in the upper part of the formation. The lowest and most conspicuous breccia bed in the southern Elkhorn Mountains typically bottoms at about 200 feet below the top of the formation; this breccia unit has been mapped locally. It is generally not well exposed, but nevertheless its presence in many places can be detected by float. Where exposed, its thickness ranges from about 10 feet to 75 feet. Thinner and less continuous beds and diversely oriented small irregular bodies of breccia, which may form interconnecting links between beds, are exposed above the principal breccia layer at a number of localities. The main breccia bed typically consists of a chaotic mass of angular block, slabs, and finer textured rubble, in part cemented by laminated yellowish or reddish calcareous mudstone similar to beds in the lower part of the Amsden formation and in part by finely crystalline calcium carbonate. The coarse detritus is almost wholly Mission Canyon limestone; chert fragments and broken beds of yellowish moderately calcareous mudstone are distinctly subordinate in amount. Small water-laid lenses of somewhat rounded and sorted limestone frag- 
ments were observed at a few places. The lithologic character, structure and invertebrate fossils (insofar as they can be determined in the field) of the limestone above the principal breccia bed are indistinguishable from the same features below the breccia.

The breccia is believed to have formed during a postMission Canyon pre-Amsden erosion interval by penecontemporaneous formation and collapse of solution caverns in the upper part of the Mission Canyon limestone. The persistence of a conspicuous breccia bed at about the same stratigraphic horizon over a considerable area may indicate the position of a preAmsden water table that remained constant for a considerable time at about the same stratigraphic position and at about the same depth beneath the erosion surface. Under the presumed conditions, a karst topography would probably have developed on the Mission Canyon. Exposures near the contact of the Mission Canyon and the Amsden are so poor, however, that no definite evidence of the nature of this contact could be found.

\section{MISSISSIPPIAN AND PENNSYLVANIAN SYSTEMS}

\section{AMSDEN FORMATION}

The Amsden formation comprises a heterogeneous assemblage of sandy, argillaceous, and dolomitic and calcareous rocks. The contact with the underlying Mission Canyon limestone was nowhere observed, but at a few localities reddish sandy and silty beds crop out within 20 feet of massive Mission Canyon limestone. This boundary is commonly mapped on the basis of a break in slope that appears to coincide with the uppermost bed of massive limestone. The Amsden formation grades upward into the Quadrant formation. In this graditional zone, red argillaceous rocks are rare or absent above the lowest conspicuous quartzite bed, and the contact between the formations is drawn at the base of the lowest quartzite bed. In covered areas the contact is mapped at the upper limit of red float.

The Amsden formation has not been measured in detail, but typically it is between 200 and 300 feet thick. The lower part, 100 to 150 feet thick, consists of mudstone and shale with subordinate amounts of argillaceous sandstone; the unit as a whole is red or grayish red, but many beds are gray, brown, or yellow. The middle part of the formation consists of medium-gray and dark-gray, thick-bedded dolomite with some argillaceous partings and fossiliferous interbeds. This unit is typically about 50 feet thick. The upper unit also is about 50 feet thick. Lithologically it is similar to the lower unit. It grades upward into an alternation of quartzitic sandstone and dolomite, which has been placed in the Quadrant formation.

\section{PENNSYLVANIAN SYSTEM}

\section{QUADRANT FORMATION}

The Quadrant formation consists of interbedded light-colored quartzitic sandstone and light-gray sugary and sandy dolomite. Its thickness ranges from 225 to 325 feet in four measured sections. In the lower part of the formation beds of dolomite and sandy dolomite predominate, but the proportion of quartzitic sandstone increases upward so that in the upper 100 feet it amounts to about 75 percent of the total rock. Typically one or two ledges of massive quartzite, each from 10 to 25 feet thick, are present in the uppermost 100 feet. Some of the quartzite beds are inconspicuously crossbedded. The following section of the Quadrant formation, measured in the Limestone Hills several miles east of the area mapped, is representative of this formation throughout the Elkhorn Mountains.

Section of the Phosphoria and Quadrant formations in the Limestone Hills, $\mathrm{NW}_{1 / 4}$ sec. $29, T .6 \mathrm{~N}$., R. $1 \mathrm{E}$.

(Measured by E. T. Ruppel and M. R. Klepper)

Upper Jurassic:

Swift formation (lower part only) :

41. Sandstone, moderate-brown to dark-yellowishbrown, silty, somewhat limonitic, mediumgrained; weathers dark yellowish brown

40. Conglomerate, rounded chert, and quartzite pebbles as much as 3 in in diameter in a sandy matrix.

Fcet

Erosional unconformity.

Permian :

Phosphoria formation:

39. Quartzite, pale-yellowish-brown, very slightly limonitic, medium-fine-grained ; contains phosphatic fragments and chips in lower half and small chert nodules in upper half

3s. Dolomite, medium-gray, medium coarsely crystalline

37. Quartzite, homogeneous, very fine grained; graditional from unit 36

36. Chert; appears fragmental to nodular when weathered; in part quartzitic; upper $4.3 \mathrm{ft}$ probably very fine-grained quartzite containing some small chert fragments.

35. Concealed

34. Chert, pale-yellowish-brown; weathers to very irregular surface

33. Concealed

32. Chert, olive-gray, somewhat sandy, weathered surfaces appear fragmental to nodular

31. Quartzite, medium gray, fine-grained, indistinctly bedded.

30. Chert, light-brown to dark-yellowish-orange, chunky; contains small ovoids or spheroids of quartz

Total thickness of Phosphoria formation. 
Permian-Continued

Quadrant formation :

29. Concealed.

28. Dolomite, medium-light-gray to medium-gray, finely to medium coarsely crystalline or granular; weathers medium light gray to light gray

27. Concealed.

26. Quartzite, pale orange, clean, vitreous, finegrained, thick and indistinctly bedded........

25. Dolomite; similar to unit 28 , but sparsely sandy and with a very irregular upper surface probably due to channeling prior to deposition of the overlying quartzite bed

24. Quartzite; similar to unit 26, but with sparse nodules and thin lenticular beds of chert......

23. Dolomite; similar to unit 28 , but slightly more calcareous

22. Quartzite; similar to unit 26

21. Dolomite; similar to unit 28, but contains sporadic irregular to subrounded chert nodules in central part and a few siliceous partings and one $0.5 \mathrm{ft}$ bed of calcareous punky sandstone in upper half: contains poorly defined siliceous ribs nearly parallel to bedding in upper $4 \mathrm{ft}$

20. Quartzite, pale-yellowish-brown, clean, vitreous, fine-grained, thickly and indistinctly bedded.-

19. Dolomite; similar to unit 28 , but contains near the base a few siliceous crusts or partings 0.1-0.4 ft apart and in the upper half sporadic small chert nodules

18. Interbedded quartzite and dolomite; beds as much as $3 \mathrm{ft}$ thick; quartzite similar to unit 26 , but is light gray to medium light gray and contains one bed, $2 \mathrm{ft}$ thick, of light-gray fine-grained clean quartz sandstone near base; dolomite is similar to unit 28 except as follows: 1 thin bed at base of unit is sandy; 1 bed in center of unit is light olive gray, very finely crystalline, contains thin siliceous laminae, and weathers light brownish gray ; in upper $2-3 \mathrm{ft}$ of unit, dolomite occurs as irregular, lenticular masses in the quartzite

17. Quartzite, light-gray to medium-light-gray, clean, vitreous, fine-grained; weathers yellowish brown - _.

16. Sandstone, light-gray to medium-light-gray, calcareous, irregularly thin-bedded and flaggy, granular on weathered surface

15. Quartzite; lower part of unit similar to quartzite of unit 17; middle part of unit is very light gray fine-grained sandstone flecked with dark brown; upper part of unit is similar to quartzite of unit 26

14. Dolomite; similar to unit 28 ; sparsely sandy and poorly bedded in lower $4-6 \mathrm{ft}$; contains $0.4 \mathrm{ft}$ bed of quartzite in the middle; upper $2 \mathrm{ft}$ finely laminated on weathered surface owing to thin layers of sand that weather in relief.

13. Quartzite; similar to unit 17 ; thin pitted layers, possibly indicating carbonate-rich zones, occur at $0.2-0.5 \mathrm{ft}$ intervals on the weathered surface
Permian-Continued

Quadrant formation-continued

12. Quartzite, pale-yellowish-brown, clean, vitreous; contains interbedded dolomite similar to that in unit 28

Feet
19

45

16

14

9

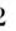

16

12

13

4

3

(1)

11. Dolomite; similar to unit 28 ; with a few chert nodules in the upper $3 \mathrm{ft}$; abundant fossil frag-

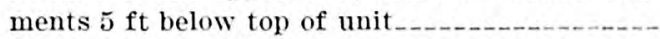

10. Quartzite, light-brownish-gray flecked with white; slightly limonitic; medium fine grained.

9. Concealed; probable dolomite interval _...........

8. Sandstone, pale-yellowish-brown, clean, vitreous, quartzitic, medium-fine-grained_

7. Dolomite; similar to unit 28 , but contains interbeds of pale-yellowish-orange to yellowishorange, clean, medium-grained quartz sandstone in upper $1.5 \mathrm{ft}$

6. Quartzite, pale-yellowish-brown, clean, vitreous; in two beds, one $0.5 \mathrm{ft}$ thick and the other $3 \mathrm{ft}$ thick; weathers yellowish orange to yellowish gray

5. Dolomite; similar to unit 28; contains brown, gray, and almost white thin irregular chert laminae in lower $2.5 \mathrm{ft}$, and from 6 to $8 \mathrm{ft}$ above base ; irregular siliceous crusts and chert nodules occur in upper $5 \mathrm{ft}$._._._._._._._._.

4. Dolomite; similar to unit 28 ; irregular siliceous encrustations on weathered surface; highly irregular weathered quartzite masses occur in

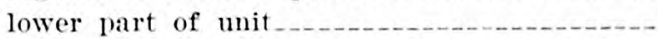

3. Quartzite, pale-yellowish-brown, clean, vitreous_-

2. Dolomite; similar to unit 28 ; in beds 0.4 to $0.5 \mathrm{ft}$ thick: sparse siliceous encrustations on weathered surface; base of unit is marked by a $1-\mathrm{ft}$ bed of pale-yellowish-orange, medium-finegrained, clean, quartz sandstone that weathers yellowish orange

Total thickness of Quadrant formation.

Pennsylvania and Mississippian :

Amsden formation (upper bed only) :

1. Dolomite medium-light gray to medium-gray, finely to medium coarsely crystalline or granular; weathers medium light gray to light gray, underlain by red shale float

Microscopically the quartzitic beds are seen to consist of well-sorted, rather well-rounded, fine- to mediumgrained quartz sand which has been cemented by overgrowths of quartz and locally by small quantities of red iron oxide. One sandy dolomite bed consists of a matrix of crystalline dolomite that encloses about 30 percent of subangular to subrounded grains of very fine grained quartz sand and a few larger rounded grains of dolomite.

The Quadrant formation, like the Flathead quartzite, is a competent, but brittle unit. Both formations yielded to deformative stresses by forming rather broad 6 folds and by breaking along many fractures. On the

(1)


eastern flank of the dome, lead-silver minerals and gold locally replace favorable carbonate beds in the Quadrant formation along or adjacent to a number of these fractures.

\section{PERMIAN SYSTEM}

PHOSPHORIA FORMATION

The Phosphoria formation in this area ranges from about 45 to 125 feet in thickness and consists predominantly of chert and quartzitic sandstone; locally one or two thin beds of phosphate rock are present. The formation is recognized throughout the area, but in places it is too thin or too poorly exposed to map separately and has been mapped with the Quadrant formation. The contact between the Quadrant and Phosphoria formations appears to be gradational. Both the thickness and the phosphate content of the formation decrease to the north and northeast within the area. The thinning probably is due mainly to lack of deposition but may in part be due to pre-Jurassic erosion. The top of the formation is an erosion surface which so far as can be determined had almost no local relief and not more than a few tens of feet of total relief in an area of 200 square miles. The erosion surface is overlain with no perceptible angularity by marine sandstone of Late Jurassic age, which generally has from a few inches to a few feet of chert pebble (rarely cobble) conglomerate at the base.

Condit (1918, p. 120) first called attention to a widespread beveling of pre-Ellis (Upper Jurassic) rocks in southwestern Montana and adjacent parts of Wyoming. $\mathrm{He}$ also suggested that 2,000 feet of strata may have been eroded as far north as Great Falls, where beds of Ellis age were deposited on the Madison limestone. This opinion is supported by the recognition of an angular unconformity between the Big Snowy group (Mississippian and Pennsylvanian) and beds of Ellis age in an area between Helena and Great Falls (Lyons, 1944 , p. 450). The relations in the southern Elkhorn Mountains, however, suggest that this area was extremely stable and little affected by erosion or deposition throughout Triassic and Early Jurassic time, and that the Late Jurassic rocks were deposited upon the upper part of the Phosphoria formation, which had not been significantly modified by erosion. This interpretation, if correct, does not invalidate Condit's basic concept of a period of Jurassic planation, but it does indicate that local areas were not sufficiently domed or uplifted to be much aflected by erosion.

The greatest thickness of phosphate rock is in the southeast corner of the area mapped (pl. 3), where two oolitic beds, one 2.75 feet and the other 0.5 foot thick, are separated by an 0.75 foot stratum of phosphatic mudstone. A bed from 4 to 12 inches thick which contains 56.98 percent tricalcium phosphate is exposed a few miles south of Elkhorn (Condit, Finch, and Pardee, 1928, p. 178) and float in Johnny Gulch that is believed to represent a bed 0.75 foot thick contains 25.35 percent tricalcium phosphate (Condit, Finch, and Pardee, 1928 , p. 177-178). A section measured in the Limestone Hills, a few miles east of the map area, is given on page 20 ; the thickest and one of the thinnest sections exposed in the area are described below :

Section of Phosphoria formation in gulch near center of sec. 28, T. $5 \mathrm{~N} ., R .1 \mathrm{~W}$.

Jurassic system: Swift formation: sandstone with thin conglomerate at base.

Erosional unconformity: concealed.

Permian system: Phosphoria formation: Feet

12. Chert, gray and brown, lumpy to laminated_---- 2-5

11. Quartzite, grayish-brown, fine-grained, sparsely phosphatic; contains chert grains _._.___._. 10.5

10. Chert, brown and gray, lumpy, nodular____._ 3.5

9. Sandstone, fine-grained, sparsely phosphatic (?) - 1

8. Chert; similar to unit 10_._. 6

7. Sandstone, phosphatic, conglomeratic, cherty

6. Chert; similar to unit $10 \ldots$

5. Phosphate rock, clastic, cherty, conglomeratic; weathers light brown speckled white ${ }^{1} \ldots \ldots \ldots$

4. Chert, lumpy and nodular; upper $1 \mathrm{ft}$ is coarsely nodular._._- 6

3. Quartzite, sparsely phosphatic (?) -

2. Limestone, dense, gray, lenticular._._._.-1

1. Chert, thinly laminated at base becoming lumpy near top _-... 6

Total thickness of Phosphoria formation 43 to 47

Pennsylvanian system: Quadrant formation: Quartzite, light-colored, and subordinate amounts of dolomite; upper few feet not exposed, contact placed on basis of float.

1 Probably similar to float sample collected in Johnny Gulch that contained 25.35 percent tricalcium phosphate (Condit, Finch, and Pardee, 1928, p. 177-178).

Section of Phosphoria formation in SW1/4SE1/4 sec. $7, T .3 N$, R. $1 \mathrm{~W}$.

Fault, approximate top of formation :

Feet

18. Sandstone, light-brown, medium-grained, argillaceous__._- 6

17. Chert, yellowish-brown, blocky and chippy_....- 10

16. Quartzite or chert, very fine grained__._._._...- 1

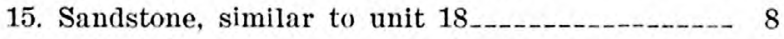

14. Concealed; chert and sandstone float_._._._-_.- 46

13. Chert, brownish-gray

12. Phosphate rock, dark-gray, very oölitic_______- 2.75

11. Mudstone, slightly phosphatic

10. Phosphate rock; similar to unit 12____- .5 
Fault-Continued

9. Chert, yellowish-brown, thinly laminated, platy to blocky -

8. Chert, phosphatic

7. Chert; similar to unit 9._._. 8

6. Sandstone, phosphatic and interbedded phosphatic quartzite and phosphate rock._._. 1.25

5. Concealed _......- 4

4. Quartzite, light-brown, vitreous

3. Concealed _...... 4

2. Quartzite, white to yellow-brown, vitreous.....- 1

1. Concealed; basal contact not exposed__._._._._. \pm 15

Approximate thickness of Phosphoria formation 125

\section{JURASSIC SYSTEM}

The Jurassic system is represented chiefly by rocks of nonmarine origin that are assigned to the Morrison formation of Late Jurassic age. Beneath the Morrison formation are a few tens of feet of marine sandstone that belongs to the Swift formation, also of Late Jurassic age.

The boundary between the Jurassic and Permian systems is easily recognized, for the friable, calcareous sandstone of the Swift formation is quite distinct from the quartzite and chert of the Phosphoria formation. Furthermore, in many places the basal bed of the Swift formation is a thin chert-pebble conglomerate, which rests with slight erosional unconformity upon the Phosphoria.

The boundary between the Jurassic and Cretaceous systems is not so easily placed. Cobban (1945, p. 1269$1270,1281)$ recognizes an erosional unconformity between the Morrison formation and the Kootenai formation in northern Montana, and Brown (1946, p. 246247 ) finds paleobotanical evidence to indicate that this unconformity represents the Jurassic-Cretaceous boundary. The sequence of Upper Jurassic and Lower Cretaceous strata in the southern Elkhorn Mountains is generally similar to that recognized farther north by Cobban, but the unconformity, if present, has not been recognized. Consequently the boundary between the Morrison and the Kootenai has been placed arbitrarily on a lithologic basis and may not correspond exactly to that drawn by Cobban.

\section{SWIFT FORMATION}

A thin and inconspicuous unit of calcareous marine sandstone is everywhere within the map area intercalated between the Phosphoria formation and the nonmarine Morrison formation. Ralph Imlay, who examined the formation in the field, considers it to be the upper unit of the Swift formation (Ellis group) of Late Jurassic age (Imlay, Gardner, Rogers, and Hadley,
1948, chart). It rests on an erosion surface of very slight relief on the Phosphoria formation and is overlain conformably by the Morrison formation.

The Swift formation in this area is from 20 to 35 feet thick and consists of punky, grayish-brown, calcareous sandstone that, typically, is speckled with grains of black chert and scattered grains of limonite. In many places one or more beds in the lower part of the formation are crowded with broken and specifically unidentifiable shells of Eumicrotis, Ostrea, and Camptonectes (Ralph Imlay, oral communication). A conglomerate as much as 3 feet thick and consisting of chert pebbles and locally cobbles commonly is the basal bed of the formation. Small pebbles occur sporadically in higher beds.

The Swift formation is too thin to be mapped separately and therefore is included with the Morrison formation as a single map unit.

\section{MORRISON FORMATION}

The Swift formation is conformably overlain by a varicolored assemblage of shale, mudstone, siltstone, sandstone, and limestone. The lower part of this assemblage of rocks is referred to the Morrison formation, for it is similar in stratigraphic position and lithologic characteristics to the Morrison farther north in Montana (Cobban, 1945, p. 1268-1270). The upper part of the assemblage resembles and is referred to the Kootenai formation as described by Cobban.

In the southern Elkhorn Mountains the Morrison formation is poorly exposed and the sequence of beds within it is known only in a general way. The apparent thickness of the formation measured from cross sections ranges from about 400 to 800 feet. This variation may be due to local differences in the thickness of sediment deposited, or to local thickening and thinning during folding, or to a combination of these two factors.

The formation consists of shale, mudstone, and siltstone, with sporadic thin beds of aphanitic, compact sublithographic limestone and fine-grained argillaceous sandstone. Many argillaceous beds are calcareous. The rocks are varicolored, and different colors predominate at different localities. Near the south end of the area the argillaceous rocks are predominantly reddish; farther north red coloration is uncommon and shades of olive, gray, brown, and yellow predominate. Throughout the area most of the sandstone beds are brownish and the limestone beds, most of which are less than 3 feet thick, are light gray, light olive gray, and greenish gray. Locally, in the upper hundred feet of the formation, drab-colored mudstones contain thick, but lenticular, interbeds of "pepper-and-salt" sand- 
stones that are indistinguishable from sandstones in the lower part of the Kootenai formation. Consequently the contact between the Morrison and Kootenai formations as mapped may vary from place to place. Where exposures are good, the boundary between the Morrison formation and the Kootenai formation is placed at the top of a unit of dark-gray, and locally sparsely lignitic, shale that probably is equivalent to the carbonaceous beds at the top of the Morrison farther north (Cobban, 1945, p. 1269). This shale is overlain by a unit of coarse-grained "pepper-and-salt" sandstone that typically is 40 to 50 feet thick and locally has lenses of pebble conglomerate at the base. Where "pepper-and-salt" sandstone beds are present in the upper part of the Morrison and where the dark shale is not evident, the contact is drawn arbitrarily and may vary as much as 100 feet from a fixed position.

Several thin sections of coarse-grained sandstones from the upper part of the Morrison and the lower part of the Kootenai formations were examined. No features were recognized in them that could be used to distinguish between the formations. In both, the predominant type of sandstone is a rather poorly sorted coarsegrained aggregate of quartz and chert in roughly equal amounts, with sparse fragments of quartzite, cherty siltstone, and detrital calcite or dolomite. Grains are subangular to subrounded and range from 0.2 to 0.6 millimeter in average diameter. Some beds are almost entirely cemented by coalescing overgrowths of quartz on quartz grains; others have a matrix or cement of small quantities of micaceous, clayey, and ferruginous minerals, and crystalline calcite. In pebbly beds, the pebbles are chert, cherty siltstone, and, rarely, quartzite; no pebbles larger than 3 centimeters in diameter were found. Zircon is a rare accessory mineral.

\section{CRETACEOUS SYSTEM}

The Cretaceous system in this area comprises a greater thickness and a greater variety of stratified rocks than any other system. It includes as much as 3,000 feet of strictly sedimentary rocks, most of them nonmarine, and at least 5,000 feet of volcanic rocks, the greater part of which are breccias and tuffs, and, therefore, in a sense, sedimentary.

The Kootenai formation, at the base of the Cretaceous system, is about 500 feet thick. It consists of "pepperand-salt" sandstone, red and green shale, and gray fresh-water limestone and is overlain, probably with slight erosional unconformity, by the Colorado formation, a thick sequence of dark shales, quartz-chert sandstones, and drab siliceous mudstones, partly of marine origin. The Colorado formation grades upward into the Slim Sam formation, a sequence of sandstones, tuf- faceous sandstones, and tuffs, which are for the most part of nonmarine origin. The Elkhorn Mountains volcanies, a thick and varied sequence consisting mainly of andesitic pyroclastic rocks, grades upward from the Slim Sam formation in some places, and elsewhere rests unconformably on older Cretaceous and Jurassic rocks. At a locality several miles south of the area mapped, similar and probably coextensive volcanic rocks rest with a $15^{\circ}$ to $20^{\circ}$ angular unconformity on Mississippian rocks. ${ }^{2}$ In the area mapped no measurable angular discordance was observed, but the magnitude of the erosional unconformity indicates that in some places the rocks must have been folded or faulted before the major period of volcanic eruption. In other places the volcanic rocks appear to be not only conformable upon but also gradational with the underlying rocks.

\section{KOOTENAI FORMATION}

The Kootenai formation of the southern Elkhorn Mountains ranges from 400 to 650 feet in thickness and comprises a basal unit characterized by "pepper-andsalt" sandstone, a medial unit characterized by red and green shale and siltstone, and an upper unit characterized by gray limestone. The rocks are of nonmarine origin.

The lower part of the formation ranges from 100 to 200 feet in thickness and consists of crossbedded, chertrich "pepper-and-salt" sandstone interbedded with shale and mudstone. The sandstone consists of quartz and chert grains and locally contains thin beds or lenses of small pebbles. The shale and mudstone beds are olive gray and grayish red; some beds contain calcareous concretions. Two or three units of sandstone beds, each from 15 to 50 feet thick, typically are present, and in a few localities four units were observed. The more strongly cemented sandstone units tend to form low hogbacks, which are forested.

The medial part of the formation ranges from 200 to 300 feet in thickness and consists predominantly of blocky siltstone and fissile shale; concretions and lentils of limestone are common throughout; sandstone is virtually absent. The siltstone and shale have a variety of colors: grayish red, grayish and dusky purple, greenish gray, and light olive gray. The concretions and lentils consist of light- to dark-gray very fine grained, almost lithographic limestone. Some contain fossil fragments and calcite crystals. Possibly half of the shale and siltstone beds contain some concretions; in a few beds the concretions are so abundant that the rock is essentially a nodular or concretionary limestone.

2 Alexander, R. G., Jr., 1951, Geology of the Whitehall area, Montana; unpublished Ph. D. thesis, Princeton Unir., p. 82, pl. 1. 
The upper part of the formation consists of 10 to 30 feet of fresh-water limestone that is overlain by drabcolored blocky mudstone or shale from a few feet to about 60 feet thick. The limestone is granular and fetid, and varies in color from light gray to dark gray. Typically it forms two or more massive beds that are separated by thin layers of calcareous shale or argillaceous limestone. Gastropod remains are abundant in some beds or parts of beds. Locally this limestone has been mapped as a key unit.

The boundary between the Kootenai formation and the Colorado formation has been placed at the top of the drab-colored mudstone or shale. This mudstone is overlain by a thin unit of fine-grained sandstone and siltstone, that is in turn overlain by dark shale. The following section of the Kootenai formation was measured along Johnny Gulch about one mile east of the area mapped.

Section of Kootenai formation on north side of Johnny Gulch in N1/2 sec. $20, T .5$ N., R. $1 \mathrm{~W}$.

[Measured by V. L. Freeman and R. F. Gosman]

Lower Cretaceous :

Colorado formation: Lower black shale unit (basal beds only) :

Sandstone; very pale orange, very fine grained, consists of well-sorted grains of quartz with limonite specks; in beds 2 to $4 \mathrm{ft}$ thick with irregular bedding surfaces; well-laminated

Mostly covered; probably underlain by olive-gray siltstone

Sandstone, yellowish-gray, very clean; consists of well-sorted, very fine grains of quartz. Beds are thin with irregular bedding and very small cross laminations

Siltstone, argillaceous, light-olive-gray ; forms slope

Siltstone, light-olive-gray, thinly laminated; forms ledge

Lower Cretaceous :

Kootenai formation:

17. Shale, calcareous, medium-gray, somewhat silty ; top $10 \mathrm{ft}$ is yellowish-gray limestone with interbedded clayey siltstone and very fine-grained sandstone in thin even beds

16. Limestone, medium-light-gray; largely detrital and of coarse sand size; abundant gastropod fragments; beds 1 in to $3 \mathrm{ft}$ thick with a few interbeds of calcareous shale that total 10 percent of unit; forms ledge.

15. Siltstone, greenish-gray, very clayey; grades in upper half to more yellowish color, locally calcite cements the coarser beds; weathers to very small hackly fragments

14. Claystone, silty, grayish-red; bed of breccia with network of calcite-healed fractures at top; weathers to very small hackly fragments _....-

13. Siltstone and claystone, very limy, light-greenishgray, thinly bedded
Lower Cretaceous-Continued

Kootenai formation-Continued

12. Siltstone and argillaceous siltstone, greenishgray to light-greenish-gray; in thin lenticular beds with many curved bedding surfaces, forms slight ledge. The cleaner beds are very hard and calcareous

11. Silty shale and argillaceous siltstone; lower half is grayish red, upper half is alternating grayish red and light greenish gray; some limy zones throughout; weathers chippy or hackly

10. Siltstone and sandstone, very fine to fine-grained, greenish-gray ; argillaceous matrix gives color; contains flakes of colorless mica; basal $2 \mathrm{ft}$ is fine-grained sandstone; weathers to small chips; contains a few moderate-brown weathering concretions as much as $2 \mathrm{ft}$ in diameter-

9. Covered

8. Limestone and siltstone alternating; siltstone like unit below ; dark-gray ; very finely crystalline, slightly fetid limestone in three beds 1 to $2.5 \mathrm{ft}$ thick; organic fragments common.

7. Siltstone, clayey; olive-gray in upper part; medium-gray claystone with limy nodules in lower part; weathers to thin chips; poorly exposed .

Sill, $14 \mathrm{ft}$ thick; includes septum of shale about $3 \mathrm{ft}$ thick.

6. Shale, grayish-purple; some greenish-gray mottling at base, grades upward to greenish-gray in upper half: very silty, contains some sand grains; contains several beds of lumpy limestone, 1-1.5 $\mathrm{ft}$ thick, that have been brecciated and recemented in part, and sporadic limestone nodules as much as 8 in in diameter.

5. Sandstone, light-olive-gray, fine-grained; consists of subangular grains of quartz and minor amounts of chert; based 4 to 6 in is conglomerate with pebbles as much as 3 in in diameter of quartzite and some chert; beds are 6 in to 2 ft thick with laminations at a gentle angle to bedding; forms ledge

4. Claystone, silty, grayish-red, hackly weathering; some irregular limy portions

3. Claystone, silty, greenish-gray and subordinately grayish-green; contains limy nodules that weather pale yellowish orange; some thinly laminated fine-grained argillaceous sandstone in upper part

2. Sandstone; like unit below but mostly covered; in thin beds that have irregular bedding surfaces; argillaceous cement in some beds is more abundant than sand grains

1. Sandstone, medium-gray, coarse-grained; consists of moderately well sorted angular grains of quartz and chert (75 percent); tightly packed but contains some cement; occurs in cross-laminated beds with shallow cut-and-fill structures of moderate size.

Total thickness of Kootenai formation 
Upper Jurassic :

Morrison formation (upper part only) :

Covered; mostly siltstone and claystone fragments; near top are chips of silty, micaceous, dark-gray shale

67

Poorly exposed; siltstone, olive-gray, with subordinate amounts of medium-gray limestone, in 1 to $2 \mathrm{ft}$ beds; one 18 in bed of fine-grained, very pale orange sandstone-

Limestone, medium-gray, very finely crystalline, very silty

Sandstone, very fine grained; siltstone, and lightolive-gray, calcareous, very hard claystone; breaks with conchoidal fracture; blocky weathering; in beds as much as 2 in thick with low angle cross laminations and shallow channeling --.---

Siltstone, light-olire-gray, hard, dense, hackly weathering; forms slope under ledge; homogeneous unit

Siltstone, light-olive-gray; limy zone at top, very hard; in beds 1 to $1 \frac{1}{2}$ in thick with minor clayey laminations; thinly laminated.

\section{COLORADO FORMATION}

The Kootenai formation is overlain, probably with slight erosional unconformity, by 1,100 to 1,500 feet of dark shale, quartz-chert sandstone, and siliceous mudstone beds that are here referred to the Colorado formation. ${ }^{3}$ The Colorado grades upward into a sequence of highly feldspathic sandstone and tuff beds, here named the Slim Sam formation. Most beds in the Colorado formation and in the lower part of the Slim Sam formation are rather nonresistant; consequently where these formations appear at the surface they are typically eroded into low rolling hills that contain relatively sparse outcrops. Nevertheless the contact between them can generally be placed rather closely on the basis of the presence or absence of black shale float.

The Colorado formation is here subdivided into three map units, a lower black shale unit, a sandstone and siliceous mudstone unit, and an upper black shale unit. A tentative correlation of these units and of the overlying formations with a reference section for the western interior of the United States is shown in the following table.

'Recently Cobban and Reeside (1951, p. $1892 ; 1952$, p. 1015) have recommended that the boundary between the Lpper and Lower Cretaceous be placed at the top of the Mowry formation and that the term Colorado be restricted to rocks of Upper Cretaceous age. Common usage In western Montana is to include all beds from the top of the Kootenai formation to the top of the Nlobrara equivalent in the Colorado shale or Colorado formation (Cobban and Reeside, 1952, correlation chart, columns 99 and 100). This usage has been adopted in the present report because of the difficulty in determining and mapping the boundary between the Upper Cretaceous and the Lower Cretaceous in this area.
Tentative correlation of Cretaceous rocks of the southern Elkhorn Mountains with reference section for western interior United States

\begin{tabular}{|c|c|c|c|c|c|c|}
\hline \multirow{2}{*}{ Age } & \multicolumn{5}{|c|}{ Group, formation, and member } & Character \\
\hline & $\begin{array}{c}\text { European } \\
\text { equiv- } \\
\text { alents }\end{array}$ & \multicolumn{2}{|r|}{$\begin{array}{l}\text { Reference sequence for } \\
\text { western interior }{ }^{1}\end{array}$} & \multicolumn{3}{|c|}{ Southern Elkhorn Mountains section 2} \\
\hline \multirow{17}{*}{ 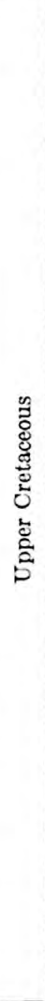 } & Danian? & \multicolumn{2}{|c|}{ Hell Creek formation } & \multirow{2}{*}{\multicolumn{2}{|c|}{$-?-?-?$}} & \multirow{4}{*}{$\begin{array}{l}\text { Predominantly ande- } \\
\text { sitic tuff, breccia, } \\
\text { and flows. }\end{array}$} \\
\hline & \multirow{2}{*}{$\begin{array}{l}\text { Mae- } \\
\text { strich- } \\
\text { tian } \\
\end{array}$} & \multicolumn{2}{|c|}{ Fox Hills sandstone } & & & \\
\hline & & \multicolumn{2}{|c|}{ Pierre shale } & \multirow{2}{*}{\multicolumn{2}{|c|}{$\begin{array}{l}\text { Elkhorn } \\
\text { Mountains } \\
\text { volcanics }\end{array}$}} & \\
\hline & $\underset{\text { ian }}{\text { Campan- }}$ & \multicolumn{2}{|c|}{ Eagle sandstone } & & & \\
\hline & San- & Tel & egraph Creek formation & \multirow{4}{*}{\multicolumn{2}{|c|}{$\begin{array}{l}\text { ?-?- } \\
\text { Upper } \\
\text { black } \\
\text { shale } \\
\text { unit }\end{array}$}} & \multirow{4}{*}{$\begin{array}{l}\text { Upper part, tuffaceous } \\
\text { sandstone and crys- } \\
\text { tal tuff. Lower } \\
\text { part, chert-quartz } \\
\text { sandstone. }\end{array}$} \\
\hline & \multirow{3}{*}{$\begin{array}{l}\text { Coni- } \\
\text { acian }\end{array}$} & \multirow{3}{*}{ 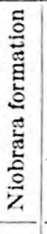 } & Smoky Hill chalk & & & \\
\hline & & & & & & \\
\hline & & & $\begin{array}{l}\text { Fort Hays limestone } \\
\text { member }\end{array}$ & & & \\
\hline & \multirow{6}{*}{$\begin{array}{l}\text { Tur- } \\
\text { onian }\end{array}$} & \multirow{4}{*}{ 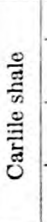 } & Sage Breaks member & \multirow{14}{*}{ 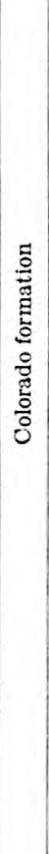 } & \multirow{9}{*}{$\begin{array}{l}\text { Sili- } \\
\text { ceous } \\
\text { mud- } \\
\text { stone } \\
\text { and } \\
\text { sand- } \\
\text { stone } \\
\text { unit }\end{array}$} & \multirow{9}{*}{$\begin{array}{l}\text { Chert-bearing "salt } \\
\text { and pepper" sand- } \\
\text { stone with local } \\
\text { pebble conglomerate } \\
\text { lenses and subordi- } \\
\text { nate shale. }\end{array}$} \\
\hline & & & $\begin{array}{l}\text { Turner sandy mem- } \\
\text { ber }\end{array}$ & & & \\
\hline & & & $\begin{array}{l}\text { Blue Hill shale } \\
\text { member }\end{array}$ & & & \\
\hline & & & $\begin{array}{l}\text { Fairport chalky } \\
\text { member }\end{array}$ & & & \\
\hline & & \multirow{4}{*}{ 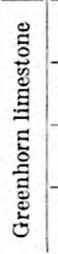 } & $\begin{array}{l}\text { Pfeifer limestone } \\
\text { member }\end{array}$ & & & \\
\hline & & & $\begin{array}{l}\text { Jetmore chalk } \\
\text { member }\end{array}$ & & & \\
\hline & \multirow{3}{*}{$\begin{array}{l}\text { Ceno- } \\
\text { ma- } \\
\text { nian }\end{array}$} & & $\begin{array}{l}\text { Hartland shale } \\
\text { member }\end{array}$ & & & \\
\hline & & & $\begin{array}{l}\text { Lincoln limestone } \\
\text { member }\end{array}$ & & & \\
\hline & & Bel & le Fourche shale & & & \\
\hline \multirow{8}{*}{ 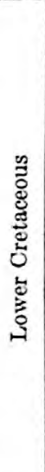 } & \multirow{6}{*}{ Albian } & \multirow{2}{*}{\multicolumn{2}{|c|}{ Mowry shale }} & & \multirow{5}{*}{$\begin{array}{l}\text { Lower } \\
\text { black } \\
\text { shale } \\
\text { unit }\end{array}$} & $\begin{array}{l}\text { Siliceous mudstone } \\
\text { and chert-rich sand- } \\
\text { stone. }\end{array}$ \\
\hline & & & & & & $\begin{array}{l}\text { Greenish-gray felds- } \\
\text { pathic sandstone. }\end{array}$ \\
\hline & & \multicolumn{2}{|c|}{ Newcastle sandstone } & & & $\begin{array}{l}\text { Dark-gray sandstone } \\
\text { and shale. }\end{array}$ \\
\hline & & \multicolumn{2}{|c|}{ Skull Creek shale } & & & Black shale. \\
\hline & & \multicolumn{2}{|c|}{ Fall River sandstone } & & & $\begin{array}{l}\text { Fine-grained sand- } \\
\text { stone and siltstone. }\end{array}$ \\
\hline & & \multicolumn{2}{|c|}{ Red shale } & & & \\
\hline & & Dr: & ney limestone & & & Limestone at top. \\
\hline & Aptian & $\begin{array}{l}\text { Bec } \\
\text { Pet }\end{array}$ & $\begin{array}{l}\text { hler conglomerate } \\
\text { erson limestone }\end{array}$ & & rmation & $\begin{array}{l}\text { and siltstone. Sand- } \\
\text { stone at base. }\end{array}$ \\
\hline
\end{tabular}

1 Cobban and Reeside, 1952, chart.

2 Modified from W. A. Cobban, written communication.

\section{LOWER BLACK SHALE UNIT}

The lower black shale unit ranges from 215 to 325 feet in thickness and comprises four subunits; (1) a basal yellowish-gray-weathering fine-grained quartz sandstone, typically about 15 feet thick; (2) drab and olivegray blocky siltstone and very fine grained sandstone; (3) rusty-weathering very dark gray or black shale with 
a few thin interbeds of siltstone and very fine grained sandstone, that grades upward into (4) dark-gray carbonaceous, and in part limonitic, speckled and slightly mottled fine-grained sandstone with some interbeds of black shale. On the basis of lithology and stratigraphic position Cobban (oral communication) indicates that the basal sandstone (subunit 1) is probably a correlative of the Fall River sandstone. The blocky siltstone and very fine grained sandstone (subunit 2) has not yielded any fossils and may be a correlative of either part of the Fall River sandstone or part of the Skull Creek shale. The lithologic character, stratigraphic position, and fossil content of the black shale (subunit 3) indicate that it is a correlative of the Skull Creek shale. Fossils characteristic of the Skull Creek have also been found at one locality in the dark-colored sandstone beds (subunit 4) about 40 feet below the top of the lower black shale unit (W. A. Cobban, written communication). Whether the uppermost beds of the lower black shale unit are correlatives of the Skull Creek shale or of the Newcastle sandstone has not been determined.

\section{SILICEOUS MUDSTONE AND SANDSTONE UNIT}

The lower black shale unit grades upward into intertongued nonmarine and marine sandstone, mudstone, and siliceous mudstone beds. In three measured sections, each a few miles east of the map area, this unit ranges from 610 to 920 feet in thickness, and can be divided roughly into three subunits: a lower subunit of olive-gray and gray mudstone and interbedded gray, speckled, feldspathic, somewhat calcareous thinbedded and in part crossbedded quartz-chert sandstone, which predominates in the lower half; a middle subunit of interbedded hard, blocky, light-gray siliceous mudstone and quartzitic and calcareous chert-rich sandstone beds; and an upper subunit of medium- and finegrained chert-rich sandstone beds, conspicuous coarsegrained "salt-and-pepper" sandstone, and subordinate shale; this subunit locally contains a conspicuous pebble conglomerate bed near the base. Some hard nonswelling blocky to fissile beds, especially in subunit 2, are probably altered bentonite or bentonitic mudstone or shale (W. A. Cobban, oral communication). Fossils ". . . known at other localities only in the Mowry and Aspen shales" (Cobban, written communication) were collected from subunit 1 at two localities. Similarity of the siliceous mudstone of subunit 2 with typical siliceous Mowry shale (Rubey 1929) also indicates that this subunit is a probable correlative of the Mowry. Fossils of Carlile age have been collected from the upper part of subunit 3 at localities only a few miles outside the map area.

The unusual rocks of subunit 2 are characterized by porcelaneous weathered surfaces in shades of gray and greenish gray, blocky to hackly and splintery fracture, abnormal hardness, and sparseness of soil formed over them. Microscopically, the siliceous mudstone consists of a holocrystalline weakly birefringent very fine grained aggregate in which are imbedded a few percent to 25 percent of smail angular fragments of quartz, feldspar, and felsite. The very fine grained aggregate has a faint green or pale-yellowish-brown tinge and an index of refraction greater than 1.54. Its components, in different specimens, have a maximum diameter of 0.01 millimeter but are typically from 0.001 to 0.005 millimeter in diameter. Some, if not all, of the sandstone beds that are interbedded with the siliceous mudstone have a cryptocrystalline matrix similar to that of the mudstone beds but contain much larger (maximum diameter, 0.4 millimeter) and much more abundant (as much as 85 percent of rock) grains. These grains are predominantly angular, even in the larger sizes, and are, in order of decreasing abundance, quartz, plagioclase (oligoclase?), and at least two kinds of aphanitic igneous rocks-one an aphanophyre and the other possibly devitrified glass.

The siliceous mudsione and the sandstone interbedded with it are, to a greater or lesser degree, products of voleanism, but the conditions under which they accumulated and the factors which were responsible for impressing upon them their present characteristics are obscure. These rocks consist of angular fragments in a predominant matrix of cryptocrystalline material. Most, if not all, of the fragments appear to be of volcanic origin. The cryptocrystalline matrix, which is probably highly siliceous, may be either a devitrified glass, possibly a pumiceous dust, or a product of the decomposition of siliceous ash by sea water and the penecontemporaneous deposition of silica (Rubey, 1929, p. 168-169).

According to Rubey, the siliceous mudstone beds of the Mowry formed on the sea floor by the chemical decomposition of slowly accumulating, very fine grained, highly siliceous volcanic ash and organic matter. He believes (p. 169) that the volcanoes from which the ash in the Mowry was derived probably were situated near southwestern Wyoming and that the clastic materials of the Mowry were probably derived from some source in central western Montana. The presence of relatively fresh shardlike quartz grains in the beds of Mowry age in the Elkhorn Mountains area,

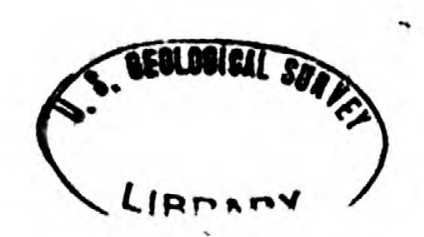


associated with considerable fine-grained clastic material suggests that the source of the volcanic material was probably somewhat nearer than southwestern Wyoming. The source of the clastic material was probably to the west of the Elkhorn Mountains, perhaps in the area now occupied by the Idaho batholith.

Typical Mowry deposits have not been described anywhere west of the area of this report. In the Philipsburg area, about 60 miles west of the southern Elkhorn Mountains, the Kootenai formation is overlain by 500 feet of black shale (Emmons and Calkins, 1913, p. 8082 ) that must be equivalent at least in part to the lower black shale unit of this report. This shale is overlain by more than 1,000 feet of sandstone with minor shale. A fossil collection from beds about 400 feet above the top of the black shale contained the same association of forms as the Oyster Ridge sandstone member of the Frontier formation of southwestern Wyoming (Emmons and Calkins, 1913, p. 82). No mention is made of siliceous mudstone similar to the Mowry or of any volcanic ash in this area.

In the Pioneer Mountains near Dillon, about 75 miles southwest of the southern Elkhorn Mountains, white tuff and blue-green porcellanite is underlain by mudstone with a few interbeds of light-colored tuff." The tuff locally contains plant fragments and leaf impressions. Based on lithology and stratigraphic position, Myers suggests that the tuff may be a coarse-grained nonmarine equivalent of the Aspen formation of southwestern Wyoming and the Mowry shale. In the Madison Range, Swanson ${ }^{5}$ (and oral communication) reports more than 2,000 feet of sandstone and shale beds of post-Kootenai age, and locally some porcellaneous fine-grained rocks that may be similar to the Mowry. In the Ruby River valley the Kootenai is overlain by several thousand feet of shale, siltstone, and sandstone. Light-colored tuff, impure bentonite and bentonitic shale, and tuffaceous sandstone and siltstone that occur near the base of this sequence may be equivalent to the Aspen or Mowry shales or to part of the Frontier formation (Klepper, 1950, p. 68-69).

These observations suggest that the western limit of the Mowry sea fluctuated across the area now occupied by the Snowcrest and Madison Ranges and the Elkhorn Mountains, but probably never reached as far west as the Pioneer Mountains and the Philipsburg area, although somewhat later, in Frontier time, an arm of the sea invaded the Philipsburg area.

\footnotetext{
"Myers. W. B., 1952, Geology and mineral deposits of the northwest quarter Willis quadrangle and adjacent Brown's Lake area, Beaverhead County, Mont.: U. S. Geol. Survey prelim. report, in open-fle, p. 10-11.

swanson, R. W., 1951, Geology of a part of the Virginia City and Eldridge quadrangles, Mont.: U. S. Geol. Survey prelim. report in open-file.
}

\section{UPPER BLACK SHALE UNIT}

The upper black shale unit consists almost entirely of very dark gray to black fissile shale that contains sporadic concretions and septarian nodules of brownweathering dense limestone. A few beds of dark-gray fine-grained sandstone and siltstone are interbedded with the shale in the lower part of the unit. The contact with the overlying Slim Sam formation is gradational over a few tens of feet. This unit ranges from 265 to 390 feet in thickness in three measured sections. The ammonite Inoceramus deformis of earliest Niobrara age (Cobban, written communication) is found in the basal sandy and silty beds; the overlying black shale contains a fauna characterized by Scaphites ventricosus, Baculites asper, and Inoceramus umbonatus, indicative of the next higher faunal zone in the Niobrara (Cobban, written communication).

\section{SLIM SAM FORMATION}

The dark shales of Niobrara age grade upward into a sequence of coarser-grained clastic rocks with a maximum thickness of 1,200 feet. The lower part of this sequence consists predominantly of gray, greenish-gray and yellowish-gray quartz-chert sandstone and the upper part of feldspathic quartz- and chert-poor sandstone with abundant beds of tuff and sedimentary tuff ${ }^{6}$ near the top. This sequence is here named the Slim Sam formation for exposures along the east margin of Slim Sam basin, in sec. 22, T. 6 N., R. 1 W., Broadwater County, about one mile east of the map area.

The base of the Slim Sam formation is placed at the lowest conspicuous bed of medium- to light-gray sandstone in a gradational zone of dominant black shale below and dominant sandstone above. Dark shale inter-beds are common in the lower 400 feet, and thin inter-beds of gray shale and siliceous mudstone occur sporadically throughout the formation. The Slim Sam formation grades upward by increase in volcanic constituents int the overlying sequence of andesitic breccias and tuffs. The contact between the Slim Sam formation and the Elkhorn Mountains volcanics is arbitrarily placed at the base of the lowest bed of coarse-textured pyroclastic rock.

The Slim Sam formation can be divided into a lower and an upper part on the basis of lithology. The lower part of the formation is relatively uniform throughout the area. It consists mainly of quartz-chert sandstone but contains beds of very fine to medium-grained crystal-lithic tuff or-sedimentary tuff and black shale that commonly contains thin lenses of coarse feldspar crystals, probably of ash-fall origin. Quartz is the

- Terminology suggested by. Wentworth and Williams (1932, p. 45-53), is used in describing pyroclastic rocks. 
predominant mineral of rocks in the lower part of the formation but probably constitues less than 5 percent of the upper part. The crystal-lithic tuffs comprise quartz grains, some with shardlike shapes, fragments of a microcrystalline rock, fresh biotite, plagioclase, white mica, and calcite cement. The terms sedimentary tuff is applied to those rocks that have an appreciable content of grains or fragments of nonvolcanic origin. The plagioclase content increases at the expense of quartz from the base to the top of the lower part of the Slim Sam formation.

The upper part of the formation consists of fine- to medium-grained crystal-lithic tuff and sedimentary tuff with at least two intervals of hard mudstone. The crystal-lithic tuff and sedimentary tuff comprise very angular plagioclase grains, with sparse gains of quartz, mica, opaque minerals, and rock fragments set in a microcrystalline matrix of chlorite and sericite. The overall aspect of the upper part is similar at different localities, but individual beds probably have little lateral persistence.

The mudstones of the Slim Sam formation are olive and dark-gray in color, contain abundant sand-sized grains, are unusually hard, and often contain plant fragments. The mudstones are hackly weathering and are normally poorly exposed.

In general the bedding of the Slim Sam formation is thinner and more regular near the base. The lower beds are usually $1 / 4$ to 2 inches thick with rare beds as much as 4 inches thick. Interbeds of black shale are generally less than half an inch thick. The beds are thicker (2 inches to 2 feet) and black shale is absent in the middle of the formation. Small shallow cross laminations are present, but scouring is not indicated. Near the top of the Slim Sam formation massive bedding of the tuff is common.

The pelecypod Mactra arenaria, probably indicating late Niobrara age (Cobban, written communication), has been found as high as 380 feet above the base of the Slim Sam formation. Other fossil remains include Scaphites cf. S. ventricosus Meek and Hayden and relatively abundant unidentifiable plant remains, mostly twigs and branches. The age of the lower part of the formation is thus established as Niobrara. The upper limit of its age is uncertain.

So far as known the Slim Sam formation is present only in a belt several miles wide in the northeastern part of the map area (pl. 1) and in an adjacent area to the northeast. Over much of the mapped area the Slim Sam formation has been thinned or removed by erosion that preceded the deposition of the Elkhorn Mountains volcanics. To the south and west the Slim Sam may never have been deposited, for the unconformity at the base of the Elkhorn Mountains volcanics increases in these directions, and possibly part of the source area of the nonvolcanic material of the Slim Sam formation was within the limits of the mapped area. The volcanic material in the Slim Sam formation almost certainly is erosional debris from the earliest units of the Elkhorn Mountains volcanic field that probably accumulated a short distance west of the area mapped, perhaps in the area now occupied by the Boulder batholith.

The three sections described below, one of which was measured in the type area, illustrate the variability in lithology and thickness of the formation from place to place.

Section of Slim Sam formation on northeast side of Aldrich Gulch along east margin of Slim Sam basin NW1/4 sec. 22, T. 6 N., R. $1 \mathrm{~W}$.

[Measured by V. L. Freeman and Dante E. Brambilla]

Upper Cretaceous:

Feet

Elkhorn Mountains volcanies (basal part only: Andesitic breccia with fragments with maximum dimension of 2 in of several types of hornblende and feldspar porphyry; matrix contains small feldspar and hornblende crystals. No bedding detected.

Gradational contact.

Slim Sam formation :

21. Mostly covered; upper part is tuff; most beds consist of fragments of feldspar crystals as much as $2 \mathrm{~mm}$ long in very fine grained matrix. Lower part is andesitic tuff with some fragments as much as $1 \frac{1}{2}$ in long of hornblende and feldspar porphyry. Thin bedding seen in float but not in outcrop.

20. Covered; float like that of unit below but finer grained and with more distinct bedding. Upper $20 \mathrm{ft}$ is probably lapilli-tuff.

19. Sedimentary tuff, sandy, light-olive-gray; consists of coarse angular grains of feldspar with minor amounts of quartz and chert

18. Covered; underlain in part by dark-gray, hackly weathering, siliceous shale containing carbonized plant remains

17. Sedimentary tuff, sandy, light-olive-gray ; consists of fine- to medium-grained, poorly sorted, subangular grains of feldspar, quartz, mica, and chert in sparse clay matrix; somewhat calcareous ; in beds $1 / 2$ to 1 in thick, becoming somewhat thicker at top; zone of iron oxide staining at top.-.-

16. Covered

15. Covered; float suggests that lower $20 \mathrm{ft}$ is hard dark shale. To northwest this part of the section is occupied by olive and dark-gray mudstone consisting of many coarse crystal fragments in clayey and silty matrix; hackly weathering-

$408366-57-3$ 
Upper Cretaceous-Continued

Slim Sam formation-Continued

14. Covered

13. Sandstone, between pale-olive and dusky-yellow, fine-grained; well-sorted subangular grains of quartz, feldspar, and chert in clayey matrix; beds 1 to 2 in thick

12. Sandstone; continuous with unit below but slightly finer grained and contains much iron oxide; forms very dark brown zone at top of cliff formed by unit below; zone discontinuous and iron oxide appears to be secondary

11. Sandstone, tuffaceous, light-olive-gray; yellowish on outcrop, medium- to coarse-grained, consists of moderately sorted subangular grains of quartz with much feldspar, slightly calcareous. Beds 2 in to $2 \mathrm{ft}$ thick with laminations $1 / 2$ to 1 in thick, cross laminations are mostly very shallow without strong scouring; rare round concretions about $1 \mathrm{ft}$ in diameter; in general, coarsest part of unit at bases becomes finer upward, but with scattered granules of a finegrained material throughout

10. Poorly exposed; scattered outcrops in lower part are like those of the unit below and in upper part are like those of the unit above; probably gradational zone

9. Sandstone, yellowish-gray to light-greenish gray, fine grained to very fine grained with rare thin irregular beds of coarse grains; grains are wellsorted and subangular; calcareous; weathers to a more yellow color than lower units; black shaly partings and chips are lacking; beds 1 to 5 in. thick

8. Sandstone, medium-light-gray; weathers light gray, very fine grained; consists of well-sorted grains of quartz and chert ( 20 percent), with thin lenses and pods of coarse grains of feldspar, mica, and rarely quartz-all crystals or fragments of crystals; calcareous; a few thin partings of black shale in thinly laminated beds; includes some slightly coarser yellowishgray sandstone

7. Covered; float like that of unit above

6. Covered ; float like that of unit below

5. Sandstone, yellowish-gray, very fine grained; well-sorted subangular grains, with some interstitial calcareous clay ; contains common irregular chips of black shale or plant fragments and thin lenses of feldspar crystals; rough bedding surfaces; beds $1 / 2$ to $1 \mathrm{ft}$ thick

4. Mostly covered; float and a few low outcrops the same as those of the unit below, but no shale seen

3. Sandstone, yellowish-gray, very fine grained; well sorted with minor argillaceous material; grains are subangular quartz and chert; thin beds $1 / 4$ to 2 in thick, thinly laminated, with thin (as much as $1 / 2$ in) dark-gray shale partings _

2. Covered

\section{Upper Cretaceous-Continued}

Slim Sam formation-Continued Offset.

1. Sandstone, light-gray, light-olive-gray, and medium-gray, very fine grained; moderately well sorted subangular grains of quartz and chert; calcareous and somewhat argillaceous; distinct beds from $1 / 2$ to 4 in thick, with rare bed $4 \mathrm{ft}$ thick; clay chips and lumps common; several thin lenses of very coarse feldspar and a few quartz grains in lower part of unit; one bed of silty limestone, 4 in thick

Total thickness of Slim Sam formation

Contact not exposed on line of section, but its position can be estimated within $10 \mathrm{ft}$.

Colorado shale (upper part only): Shale, dark-gray to grayish-black; in part silty ; contains sparse sandsized grains, some mica flakes, and plant remains; hackly weathering.

Section of Slim Sam formation on north side of Indian Creek in $N^{1 / 2} S^{1 / 4}$ and $S^{1 / 2 N W 1 / 4 ~ s e c . ~} 6, T .6$ N., R. $1 E$.

[Measured by M. R. Klepper and V. L. Freeman]
Upper Cretaceous:

Elkhorn Mountains volcanics (basal part only) : lapillituff grading upward into tuff breccia with abundant 3- to 4-in fragments of andesitic rock

Gradational contact.

Slim Sam formation:

39. Crystal tuff, finer grained than that below, indistinct cross lamination

38. Crystal tuff, coarse-grained, and lapilli-tuff; indistinct bedding

37. Lapilli-tuff, greenish-gray ; no bedding seen----

36. Sedimentary tuff and crystal tuff; pale yellowishbrown and light-olive-gray, fine- to mediumcoarse-grained, slightly to moderately calcareous; distinctly but irregularly thinly bedded.-

35. Sandstone, sedimentary tuff, and crystal tuff, brownish-gray and pale-yellow-brown, very fine to medium-coarse-grained, rusty-weathering; in distinct irregular thin to medium-thick beds ; slightly calcareous in part

34. Covered

33. Lapilli-tuff; grades up to greenish-gray tuff breccia with some 6 in fragments; no recognizable bedding

32. Crystal tuff, poorly exposed, greenish-gray, coarse-grained, thin- to medium-thick bedded_

31. Sedimentary tuff, gray, medium-grained, wellbedded.

30. Lapilli-tuff, coarse-textured, poorly exposed_---

29. Crystal tuff or sedimentary tuff, greenish-gray; contains a few small subangular pebbles in lower $10 \mathrm{in}$; in part well-bedded; in irregular thin to medium-thick beds.

28. Covered

27. Crystal tuff with some beds of lapilli-tuff in upper $12 \mathrm{ft}$; one bed of greenish-gray tuff breccia with fragments as large as 4 in; bedding distinct but somewhat irregular 
Upper Cretaceous-Continued

Slim Sam formation-Continued

26. Covered.

25. Tuff, greenish-gray, fine-grained, poorly bedded.-

24. Tuff, greenish-gray, fine- to medium-grained; indistinctly to moderately well bedded

23. Corered; float of greenish-gray, fine- to medium grained tuff or sedimentary tuff_.

22. Crystal tuff, greenish-gray, medium-grained

21. Covered

20. Lapilli-tuff and coarse crystal tuff, greenish-gray ; thick indistinct beds with a few thin finer grained beds near top.

19. Covered

18. Sedimentary tuff or crystal tuff; greenish-gray fine-grained poorly bedded.

17. Crystal tuff, greenish-gray, poorly bedded.......

16. Sedimentary tuff, fine- and medium-grained; and light-gray to light-bluish and greenish-gray siltstone; weathers rusty ; somewhat irregularly but well-bedded.

15. Covered

14. Lapilli-tuff, light-gray, fine-grained; slightly calcareous matrix, lapilli of andesitic rock

13. Covered.

12. Lapilli-tuff, light-gray, fine-grained; weathers rusty; slightly calcareous matrix; poorly bedded; lapilli of andesitic-rock

11. Covered; probably underlain by rock similar to that in unit above.

10. Covered; no dusky-yellow-orange sandstone float above $2 \mathrm{ft}$ above base

9. Sandstone, fine-grained, thin-bedded, partly calcareous, partly limonite-speckled; weathers dusky yellow orange; mostly covered......-.-

8. Covered

7. Sandstone, argillaceous, thin-bedded, brownweathering, medium-grained, slightly calcareous

6. Covered

5. Sandstone, medium-grained, slightly calcareous, thin-bedded; weathers yellow gray

4. Covered.

3. Sandstone, medium-gray to olive-gray, mediumto fine-grained, argillaceous and in part strongly calcareous; weathers light olive gray to yellow gray ; in distinct beds $1 / 4$ to 2 in thick

2. Covered.

1. Sandstone, mottled, medium-gray, argillaceous, feldspathic, thin-bedded

Total thickness of Slim Sam formation

Colorado formation: Upper black shale unit (upper part only ) : Black shale-not measured.

Section of Slim Sam formation along shallow gully that approximately coincides with boundary between NE1/4 and $S E_{1,1}^{1,}$ sec. 更, T. \& N., R. $1 \mathrm{~W}$.

\section{[Measured by M. $\mathbf{R}$. Klepper]}

Upper Cretaceous :

Elkhorn Mountains volcanics : Tuff, lapilli-tuff, and tuff breccia, predominantly greenish gray. Not measured.
Upper Cretaceous-Continued

Slim Sam formation:

22. Covered interval

21. Mudstone, medium-gray, hard, blocky to chippy --

20. Crystal tuff, greenish gray, coarse-grained, indistinctly bedded, quartz-free (?)

19. Covered interval

18. Crystal tuff, similar to unit 20

17. Covered interval.

16. Covered interval; underlying rock is in part mudstone

15. Mudstone, medium-dark-gray and olive-gray; hackly to chippy weathering.

13. Covered interval; in part underlain by darkcolored mudstone-

12. Sedimentary tuff, with thin layers of crystal tuff-

11. Covered interval

10. Sedimentary tuff, light-gray, speckled; contains a few thin layers and lenses of feldspathic crystal tuff.

9. Sedimentary tuff; similar to unit $10 \ldots$

8. Crystal tuff, light-olive-gray, highly feldspathic, sparsely micaceous, in beds from 2 to 6 in thick, crossbedded; lowest exposed unit of quartz-poor rocks rich in volcanic material_-_

7. Sandstone, light-olive-gray, grains of chert abundant, medium- and fine-grained, in beds from 1 to $3 \mathrm{ft}$ thick

6. Mostly covered; a few small outcrops of sandstone similar to unit 7

5. Sandstone, light-olive-gray, fine-grained; contains abundant chert grains, in part thickly and irregularly bedded; contains a few thin beds of medium-gray shale

4. Covered interval

3. Sandstone, grayish-orange and yellowish-gray, fine-grained, thin- to medium-thick-bedded; contains scattered woody fragments and abundant chert grains; micaceous.

2. Sandstone, light-olive-gray, thin-bedded, nonresistant; contains a few thin beds of siltstone in lower half.

Feet

Total thickness of Slim Sam formation

1. Andesite dike, $9 \mathrm{ft}$ thick.

Colorado formation: Upper black shale unit: Shale ( 80 to 90 percent), dark-gray to very dark gray, chippy to fissile, and dark-gray, very fine grained, micaceous sandstone (10 to 20 percent) ; shale contains sporadic moderate-yellowish brown-weathering limestone concretions with a maximum diameter of 6 in GENERAL FEATURES

Volcanic rocks, here named the Elkhorn Mountains volcanies, overlie the Slim Sam formation and older sedimentary rocks. They are widely distributed in and around the Elkhorn Mountains in a plateaulike 
accumulation more than 10,000 feet thick. In the area mapped, more than 5,000 feet of volcanic rocks are present, comprising units of crystal tuff, lapilli tuff, tuff breccia, breccia, and volcanic conglomerate, mainly or wholly of andesitic composition; andesite and basalt flows; and welded tuff of quartz latitic and andesitic to calcic quartz latitic composition. Some of the fragmental rocks are deposits of ash and lapilli, others are clearly water laid. Some of the breccia units are thought to be mudflows; others are probably flow breccias. Flows and most units of coarse fragmental rocks appear to be lenticular and of limited extent, but most units of the welded tuff and the crystal tuff interlayered with them are probably extensive, though it is difficult or impossible to trace any unit for long distances because none of the units are particularly distinctive and because exposures are generally poor except in local areas.

The sequence of volcanic rocks differs from place to place within and adjacent to the area and accordingly no single section has been designated as a type section. Nevertheless, in the region east of the Boulder batholith the volcanic rocks are divisible into three members of which only the lower and middle members are present in the area of this report. The middle member locally appears to be unconformable on the lower member and may be unconformable more generally. The feasibility of subdividing the formation into members was not recognized until the mapping had been completed. A field check in 1956, however, provided additional information necessary to place the approximate boundary between the lower and middle members in and near the Tizer Basin (lower limit of conspicuous units of welded tuff on pl. 1).

The lower member consists mainly of andesitic fragmental rocks with a few andesitic and basaltic flows and a few thin welded ash flow tuffs of andesitic to calcic quartz latitic composition. This member, which in places is probably more than 3,000 feet thick, was extruded, probably from fissures, on a terrain with local relief of several hundred to perhaps as much as 1,500 feet. The middle member consists essentially of units of welded tuff alternating with units of ash-fall crystal tuff and water-laid volcanic ejectamenta. It probably accumulated rapidly and built up a stratiform pile at least 2,500 feet thick overlying the generally flattish but locally somewhat eroded and perhaps even gently deformed surface on top of the lower member. The welded tuff in this unit is mainly or wholly quartz latitic in composition. The interlayered ash-fall tuff and volcanic sedimentary rocks appear to be predominantly andesitic. In the area of this report the top of the Elkhorn Mountains volcanics has been eroded away, but more recent mapping to the north, south, and west indicates that the welded tuff member was overlain by a third member consisting largely of water-laid andesitic volcanic sediments, and that in places the total thickness of volcanic rocks at the close of the period of volcanism was in excess of 10,000 feet.

Only meager evidence bearing on the age of the Elkhorn Mountains volcanics has been found. It is known that volcanic activity in or near the area commenced in late Niobrara time, for fossils of that age are found in the Slim Sam formation, which contains andesitic detritus. The Slim Sam formation appears to have been deposited rapidly. In places it grades into the Elkhorn Mountains volcanics, thereby suggesting that the oldest rock in the Elkhorn Mountains volcanics may be as old as the Telegraph Creek formation. No fossils have been found in the Elkhorn Mountains volcanics in the area mapped, but fossils from several localities in adjacent areas indicate a Late Cretaceous age, probably equivalent to Judith River time.

The Elkhorn Mountains volcanics are the youngest rocks in this area that have been involved in the major episode of Laramide folding. They also have been extensively intruded by rocks of the Boulder batholith and by older plutonic rocks, some that were emplaced during the period of volcanic activity as shown by their presence as fragments in volcanic breccias. In the lower parts of the area the Elkhorn Mountains volcanics are overlain with strong angular unconformity by poorly consolidated sedimentary rocks of lower Oligocene to Quaternary age. The higher parts of the area probably have been continuously exposed since the time of accumulation of the volcanic rocks, and consequently the maximum original thickness of these rocks is nowhere preserved.

\section{DISTRIBUTION}

Parts of the Elkhorn Mountains volcanics have been shown as andesites and latites on maps by Weed (1901, pl. 45), Stone (1911, pl. 3), Knopf (1913, pl. 1), Pardee and Schrader (1933, pl. 2), and Berry (1943, pl. 1). From their work, the volcanic rocks are known to extend discontinuously from the Jefferson River northward to Helena, and from the Townsend Valley westward to the Deer Lodge Valley. This general area is here designated the Elkhorn Mountains volcanic field.

In the area of the present report, the volcanic rocks are exposed in the broad syncline east of the Boulder batholith in the south half of Clancy quadrangle and along Elkhorn Creek south of Elkhorn. Erosion has stripped all the volcanic rocks from the crestal part of the major dome in the Devils Fence quadrangle, but a broad belt of these rocks extends discontinuously along the east flank of this dome from 1 to 3 miles east of the 
map area linking the exposures in the southeastern corner of the Devils Fence quadrangle to those in the Clancy quadrangle. The Elkhorn Mountains volcanics also underlie large areas immediately north, east, and southwest of the mapped area.

\section{IITHOLOGY}

The Elkhorn Mountains volcanic rocks comprise a sequence of tuffs, breccias, and flows that are predominantly fragmental and andesitic and related hypabyssal intrusive rocks. Quartz latitic welded tuff and basalt flows are present in smaller amounts. The principal units have been separated in the field primarily on the basis of megascopic textures and structures. The pyroclastic rocks, following the usage of Wentworth and Williams (1932, p. 51-53), include tuff breccia, lapilli tuff, massive and well-bedded crystal and crystal-lithic tuff, and volcanic conglomerate. Other rocks include flows and flow breccia, welded or partly welded ash-flow tuff, and porphyritic to equigranular sills, dikes, and small irregular plutons of intrusive facies of the volcanic rocks. Coarser fragmental rocks consisting mainly of large fragments are called breccia and those containing a conspicuous amount of fine-grained matrix are called tuff breccia. Lapilli tuff is similar to the coarser fragmental rocks but contains smaller fragments and commonly has a relatively high proportion of tuff matrix.

The breccia, tuff breccia, and lapilli tuff form massive poorly bedded units, varicolored in somber hues of green, red, brown, and gray, as much as several hundred feet thick, and consisting of a jumble of angular to subrounded fragments of various types of andesitic, latitic, and fine-grained dioritic rock in a matrix of broken crystals of plagioclase and relatively sparse hornblende, pyroxene, potash feldspar, and epidote interspersed with finer grained material of undetermined composition. Many of the breccia and coarser grained tuff breccia units are probably of mudflow origin; most or all of the fragments are of a single rock type, in a matrix of similar appearance and probably similar composition. The units are massive, poorly sorted to unsorted, and closely packed. The lapilli tuff and finer grained tuff breccia are probably mainly of pyroclastic origin; they commonly contain fragments of several volcanic rock types, generally show some sorting and bedding, and are less closely packed. Some units appear to be gradational between true pyroclastic rocks and volcanic conglomerate. Fragments range from less than 1 inch to, rarely, several yards in diameter, although in most beds the largest fragments are less than 1 foot in diameter. Fragments of rocks older than the volcanic rocks have been observed but are very rare. Breccia, tuff breccia, and lapilli tuff that form such conspicuous units in the lower member of the volcanic rocks are not common in the middle member.

In both the lower and middle members, some tuff units are massive or thick and indistinctly bedded, some are distinctly bedded and some are strikingly thinly and evenly laminated. Some of the bedded tuff units show crossbedding, small-scale channeling, and mud cracks. Some are clearly water laid; others are almost certainly of direct ash-fall origin. The material in some beds is poorly sorted and in others excellently sorted; most of it is angular. The range of grain size in different beds is from fine silt to very coarse sand. Most of the tuff units are greenish gray, gray, dark purplish gray, or almost black. Individual units range from a few feet to as much as 200 feet in thickness, though most wellbedded units are less than 50 feet thick. The coarser fraction of the tuff and the tuffaceous matrix of the coarser fragmental rocks consist largely of broken plagioclase crystals. The finer fraction is generally a cryptocrystalline aggregate that is perhaps devitrified glassy ash. Some tuff contains small fragments of volcanic rocks. Water-laid tuff associated with volcanic conglomerate is common in the lower member of the formation, forming conspicuous units in the lowermost 1,000 to 1,500 feet of volcanic rocks in the vicinity of Elkhorn and Crow Peaks (pl. 1), from 500 to 3,000 feet above the base in the Radersburg Pass-Leslie Lake area, and in the lowermost 1,000 or 1,500 feet of section in the vicinity of Hall and Longfellow Creeks. Units of laminated tuff of probable ash-fall origin commonly lie between welded ash-flow tuffs in the middle member of the formation.

Volcanic conglomerate, consisting of pebbles, cobbles, and a few boulders of one or more volcanic rock types in a matrix of broken crystals, is commonly interbedded with crystal tuff in the lower member of the volcanic rocks and is present locally in the middle member.

Lava flows have been recognized at a number of places in the lower member of the volcanic rocks. One or more flows is probably present in any complete section of the lower member, but it is doubtful that any single flow is of widespread extent. The Radersburg Pass-Poe Park section contains two andesite flows and one thick basalt flow. The andesite flows are greenish to brownish gray; the tops and bottoms of the flows are rubbly-weathering brecciated vesicular and amygdaloidal and the centers are massive. The flows are very fine grained and contain common phenocrysts of plagioclase and sparse phenocrysts of a mafic mineral. The basalt flow is very dark gray, weathering brownish gray. It is in part brecciated and rubbly weathering and contains vesicles and amygdules irregularly distributed from top to bottom. 
No lava flows have been recognized in the middle member of the volcanic rocks.

The welded or partly welded ash-flow tuff units are streaky, banded rocks with a dense structureless to strongly banded groundmass studded with crystals and crystal fragments, sparse to abundant volcanic rock fragments, and oriented ribbons or clots of different colored and generally coarser textured material. These ribbons and clots, which are probably collapsed pumice fragments, appear in cross section as subparallel elongate thin streaks or bands ranging from less than a millimeter to about half a centimeter in thickness and in the plane of flow as irregularly bounded roundish or oval-shaped bodies as much as a few feet in diameter. In thin section some rocks of this type are seen to contain many shardlike crystal fragments and flow lines that encircle crystals and crystal fragments. The groundmass is cryptocrystalline and indeterminate whereas commonly the clots or streaks are more coarsely crystalline aggregates of quartz and, locally, feldspar, epidote, biotite, chlorite, and calcite.

The few thin welded tuff units in the lower member and some of the welded tuff in the middle member are greenish gray and contain chloritic clots. These are probably calcic quartz, latitic to andesitic in composition. Most of the welded tuff units in the middle member are dark gray to black on fresh surface and weather purplish or reddish gray. They are characterized by thin ribbons composed of fine-grained quartz and feldspar and by abundant plagioclase phenocrysts. These are of quartz latitic composition as indicated by the analysis below :

Analysis of welded tuff from west side of Tacoma Gulch SE1/4 sec. 34. T. $6 \mathrm{~N}, \mathrm{R} .3 \mathrm{~W}$.

Analysis by rapid method by S. M. Berthold and E. A. Nygaard, U. S. Geological Survey]

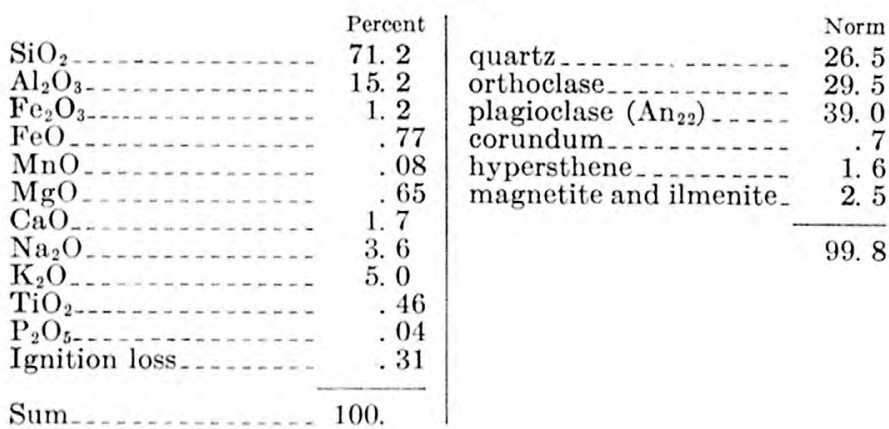

Most of the volcanic rocks have been altered at least slightly. Epidote, chlorite, silica, and calcite are common and have been formed in part by deuteric processes and probably in part by low-grade thermal metamorphism during the volcanic episode or perhaps subsequently when the Boulder batholith and its satellitic bodies were emplaced. Devitrification of glass and slight recrystallization of most of the fragmental rocks may be due in part to load and in part to the effect of low-grade thermal metamorphism caused by contemporaneous dioritic intrusives that occur throughout the volcanic pile. In a belt ranging in width from a few tens of feet to at least a thousand feet adjacent to the batholith, the rocks are strongly recrystallized to hornfels or a granulose rock, consisting mainly of feldspar, quartz, and biotite, and their primary features are largely obliterated. Locally the rocks have been sericitized, silicified, and pyritized by hydrothermal solutions that were probably derived from the same source as the batholith and related intrusives.

The maximum thickness of Elkhorn Mountains volcanics in the area mapped exceeds 5,000 feet, but the stratigraphy and structure of the formation are imperfectly known for several reasons: some of the units are lenticular, similar lithologic types are repeated throughout the section, much of the area is covered by glacial debris or by modern soils and vegetation, and not all of the area was studied in detail. Few key units or groups of units were recognized that could be traced for more than a mile or two and consequently minor folds and faults have certainly gone unrecognized. Units traced are shown on the map (pl. 1). The units are intentionally not terminated at one or both ends if no evidence was found to indicate whether their apparent termination was due to lack of deposition, intravolcanic erosion, faulting, or merely to lack of exposure.

The thickness of the Elkhorn Mountains volcanics varies throughout its area of exposure, partly because of the relief of the surface on which it was deposited and partly because of subsequent deformation and erosion. The greatest thickness is probably preserved in the trough of the broad syncline that extends from the vicinity of Radersburg Pass to a point not far east of the mouth of Crazy Creek (pl. 1). The oldest volcanic rocks in the area are probably exposed between Radersburg Pass and Leslie Lake (pl. 1), where the trough of the broad syncline probably coincides with a valley or depression in the erosion surface on which the volcanic rocks accumulated. The lower member of the formation in this part of the area can be divided into three parts. The basal part, about 1,000 feet thick, consists of breccia and lapilli tuff with a few thin units of andesitic welded tuff and one andesitic flow. Several sills intrude this part of the formation. The middle part, 800 feet thick, consists mainly of massive and well-bedded tuff with interbedded lapilli tuff and volcanic conglomerate. The upper part, about 750 feet thick, consists from bottom to top of an andesitic flow, a crystal tuff unit, and an amygdaloidal basalt flow. Along the west flank of the 
syncline in the vicinity of Elkhorn Peak (pl. 1), 3 miles northwest of this section, the basal 600 feet of the formation is predominantly massive and well-bedded crystal tuff with one flow and one thick lenticular limestone unit near the bottom; the overlying 700 feet is breccia and tuff breccia with a well-bedded tuff unit at the top. Immediately north of South Fork Lakes (pl. 1) , 3 miles east of the Radersburg Pass section, the basal 2,000 feet of the formation consists predominantly of massive crystal tuff, lapilli tuff, and tuff breccia, with a well-bedded crystal tuff unit at the top.

The middle member of the formation, consisting of alternating welded or partly welded ash-flow tuff and layered pyroclastic rocks, mainly crystal tuff, occupies the central part of the broad syncline in and adjacent to the Tizer Basin. The base of the middle member was not mapped in detail but has been determined by field checking in 1956 to lie within a zone of variable width extending from the northwestern part of sec. 29 , T. 7 N., R. $2 \mathrm{~W}$, southeastward beneath glacial fill to the vicinity of the Ballard mine, thence southward along the east rim of the cirque occupied by Glenwood Lake to the 8,981-foot knob in sec. 8 , T. 6 N., R. 2 W., thence eastward through the approximate heads of the South Fork of Crow Creek and Blacker Creek (pl. 1). It has not been traced northeast of the head of Blacker Creek. The volcanic rocks west of the Tacoma Gulch fault also belong to the middle member of the formation. Here the section is largely welded tuff with only a few thin units of crystal tuff.

Metamorphosed carbonate rock is present at two horizons near the base of the volcanic rocks on the southwestern flank of Elkhorn Peak. The lower unit, between 10 and 20 feet thick, is interbedded in the basal 50 feet of the volcanic rocks, into which a sill-like offshoot from the Boulder batholith has been emplaced (pl. 1 and $4 A$ ). It consists of dense light-colored calcsilicate hornfels with sporadic irregular masses of sulfide-bearing tactite and is clearly the product of thermal metamorphism of an impure, probably tuffaceous, carbonate rock. Along the upper horizon, which is about 200 feet higher, are a number of lenticular masses of coarsely crystalline calcite marble, the largest as much as 100 feet thick and perhaps 1,500 feet long. The large lens forms a conspicuous white band near the top of the cirque containing Icy Lake (pl. $4 A$ ) and can be clearly seen from the valley of the Boulder River, 10 miles to the south. The lenticular marble masses rest conformably upon andesitic crystal tuff and are overlain by tuff breccia. Weed (1901, p. 449) postulated that the marble on Elkhorn Peak represented "blocks torn off from the underlying Madison limestone and borne into their present position by the force of the ascending magma" but Knopf (1913, p. 130) correctly recognized that it was of sedimentary origin, because it rested conformably on beds of tuff, and suggested a tentative correlation between it and a limestone containing fossil gastropods and ostracods that is interbedded with andesite southwest of Elliston, about 30 miles west of the map area. The present authors think it most likely that the carbonate rock was deposited as calcareous tufa by thermal springs early in the period of vulcanism and that subsequent metamorphism obliterated the characteristic features by which tufa deposits are generally recognized.

Two other occurrences of limestone or calcareous shale are known in the Elkhorn Mountains volcanics, one probably near the base of the formation in a fault block on the west slope of Tacoma Gulch (pl. 2) and the other at or near the top of the volcanic pile on the east flank of Bull Mountain, about 3 miles west of the southern part of the area mapped.

The volcanic rocks are cut by many hypabyssal intrusives of the same age and composition as the volcanic rocks. Some intrusives are easily recognized and have been mapped separately; others that could not readily be distinguished from the volcanic rocks because of poor exposure and very subtle differences in appearance (especially differences between units of massive tuff and fine-grained dioritic intrusives) are included in the undivided volcanic rock map unit.

Dioritic rocks of varied texture and indefinite or indeterminate structural habit are exposed at a number of places. In particularly good exposures along the ridge east of Longfellow Creek (pl. 1) rocks interpreted as flow breccia, tuff breccia, and intrusive fine-grained diorite porphyry appear to grade into one another. Elsewhere massive tuff, containing vaguely outlined lapilli that are similar in appearance and probably of about the same composition as the matrix, locally contains large hornblende crystals as much as an inch long. These crystals are unfractured and seem to be incompatible in size with other mineral fragments in the tuff. Furthermore, the observed abundance of these crystals increases near undoubted intrusive masses.

The origin of these rocks is not clear. Some probably are recrystallized or deuterically altered pyroclastic rocks adjacent to diorite intrusives; others probably are intrusion breccias in which dioritic magma intimately invaded pyroclastic rocks, concomitantly recrystallizing and altering them; still others may be brecciated and partly altered intrusive rocks. Only those rocks that are clearly intrusive are shown as diorite on the maps.

A representative section of the Elkhorn Mountains volcanics in the northern part of the map area follows: 
Section of Elkhorn Mountains volcanics from Radersburg Pass (NW1/4 sec. 19 , T. 6 N., R. 2 W.) northeast along ridge crest east of Queen Gulch, then north and northeast along the ridge east of Tizer Creek and Little Tizer Creek to trail south of Poe Park (SE1/4 sec. 27 , T. 7 N., R. 2 W.)

\section{[Thickness approximate]}

Knob 700 feet south of trail crossing in Poe Park saddle.

Top of section not exposed.

31. Tuff breccia, greenish-gray ; subangular to subrounded fragments in crystal matrix, possible mudflow origin

30. Mostly covered. Probably underlain by one or two alternations of tuff and welded tuff

29. Welded tuff, similar to unit 20

28. Crystal tuff, light-greenish-gray; lower part well bedded to laminated; upper part massive; contains some beds of hard siliceous mudstone; cut by thin sill of diorite porphyry

Pyroxene diorite porphyry, probably a sill about 40 feet thick.

27. Welded tuff, dark-gray, dense; characterized by abundant long thin parallel ribbons (in cross section), probably collapsed pumice fragments

26. Crystal tuff and tuff breccia, greenish gray, epidoterich ; middle part is massive medium-grained homogeneous plagioclase and epidote-rich andesitic crystal tuff virtually devoid of mafic and opaque minerals; toward top and bottom of unit tuff grades into tuff breccia in which fragments and matrix are so similar that they can be detected only on weathered surfaces; forms knob in $S W 1 / 1$ sec. $34, T$. $7 \mathrm{~N}$., R. $2 \mathrm{~W}$

25. Crystal tuff, gray and greenish-gray, massive to indistinctly bedded; sand- and silt-sized particles_-

24. Welded tuff with several conglomerate beds or lenses, 6 in to $2 \mathrm{ft}$ thick; contains abundant small rock fragments and flat chloritic discs. Conglomerate beds contain cobbles of welded tuff. Probably comprises several thin welded tuffs separated by erosional debris of welded tuffs. Cliff exposure

23. Mostly concealed. Probably underlain mainly or wholly by tuff with pyroxene diorite intrusive (thin sill?) near top

22. Welded tuff alternating with crystal tuff. Welded tuff units of two general types, similar to unit 11 or tot unit 20 below. Both types may contain sparse to abundant, generally small rock fragments. Individual units range from 10 feet to 100 feet thick and are separated by units of crystal tuff, partly massive, partly indistinctly bedded, and partly laminated ; units comprising sand and silt size particles predominate, but granule, pebble and cobble beds are present locally. Gray, brown, greenish gray and purple or purplish black. Channeling, crossbedding and mud cracks observed in crystal tuff at a few places. Individual crystal tuff units range from a few feet to 60 feet thick

21. Welded tuff, dark-gray ; weathers light purplish gray ; contains abundant small plagioclase crystals and (in cross section) long thin, parallel ribbons of collapsed pumice and sparse small rock chips ; probably quartz latitic in composition

20. Welded tuff, greenish-gray ; contains flat disks, commonly as much as 1 in. across, and abundant smaller wisps of chloritic material that probably are collapsed pumice, plagioclase crystals, and abundant small fragments (few larger than 1 in.) of red and green volcanic rocks; probably of andesitic composition; forms the 8,981-ft knob in NE1/4 sec. 8, T. 6 N., 2 W.

Feet

Possible unconformity. Contact between lower and middle members of formation. Section offset 0.6 mile along top of unit 18. At south end of offset a basalt flow at least 40 feet thick (top not exposed) overlies unit 13 and at north end of offset welded tuff, $20 \mathrm{ft}$ thick, overlain by a 25 -ft unit of crystal tuff is between units 20 and 19 .

19. Crystal tuff, purplish-gray, water laid; mostly well bedded; ranges in grain size from silt to granule but is dominantly sand sized.

18. Basalt flow, very dark gray; weathers brownish gray; in part rubbly and brecciated ; amygdular with zones of abundant amygdules irregularly distributed from top to bottom

17. Mostly covered; partly or wholly underlain by massive to poorly bedded purplish-gray tuff

16. Andesite, greenish- to brownish-gray, very fine grained; contains plagioclase and few mafic phenocrysts and scattered chloritic amygdules; massive center with rubbly to blocky brecciated top and base; probably a flow. Top of unit is at sharp curve in road in $\mathrm{NE}^{1} / 4$ sec. 17 , T. 6 N., R. $2 \mathrm{~W}$

15. Covered interval, possible fault

14. Crystal tuff, andesitic, mainly sand-sized material; partly massive, partly distinctly bedded and waterlaid; contains sporadic lapilli beds; locally top of unit is boulder conglomerate, crudely bedded, as much as $30 \mathrm{ft}$ thick, consisting of subrounded to rounded cobbles and boulders, mostly less than $1 \mathrm{ft}$ in diameter, of several types of plagioclase-bearing volcanic porphyry

13. Volcanic conglomerate, andesitic, gray to purplish gray, rubbly weathering, poorly bedded; consists of cobbles, mostly subrounded, of volcanic rocks in matrix of volcanic sand ; contains interbeds of cobbly volcanic sandstone or crystal tuff, a few channel fillings of crystal tuff, and one of boulder conglomerate ; upper $40 \mathrm{ft}$ mainly gray crystal tuff of coarse sand and granule size

12. Covered interval, probably underlain by rocks similar to those in unit 11.

11. Crystal tuff; andesitic; sand and silt sized particles with some volcanic cobble beds in lower half; volcanic cobble-boulder conglomerate with a few lenses of sand and silt-sized tuff and several beds of angular lapilli tuff in upper half; probably mainly water-laid

10. Ash-flow tuff, greenish- to purplish-gray, partly welded; conspicuous chloritic clots, probably collapsed pumice fragments, in lower 10 feet; upper 5 feet is lapilli tuff, probably the unwelded top of the ash flow 
9. Crystal tuff, water-laid; distinct lenticular beds 6 in to $2 \mathrm{ft}$ thick; silt- sand- and granule-sized, particles, contains two volcanic boulder-cobble lenses, one $2 \mathrm{ft}$ and one $1 \mathrm{ft}$ thick

8. Breccia, brown, gray and purplish-gray; probably of mudflow origin; fragments range from small chips to 10 -ft blocks, mainly of one fine-grained plagiophyric andesitic type, in crystal matrix; a few quartzite fragments; no bedding but indistinct coarser and finer textured zones; matrix weathers in part very rubbly and in part hard and blocky and is difficult to distinguish from fragments on fresh surface; fragments range from angular to rounded and are mostly subangular to subrounded.-

7. Ash-flow tuff, partly welded, similar to unit 10 . Lower part is collapsed and welded; upper part is lapilli tuff

6. Breccia; closely packed angular to subrounded fragments, as much as 6 in across, of several porphyritic andesitic rock types in lower and upper part; fewer and smaller fragments in middle part; possibly of mudflow origin

5. Covered interval, outcrops of welded tuff from 75 to 100 ft below top

4. Welded tuff, purplish- and greenish-gray. Flattish chloritic discs and wisps and small rock fragments common.

Hornblende diorite porphyry intrusive, probably a sill about $15 \mathrm{ft}$ thick.

3. Andesite flow; basal part, rubbly weathering vesicular; center, massive plagiophyric; top, rubbly weathering with abundant flattened vesicles and amygdules.

Hornblende diorite porphyry intrusive and probable fault in covered interval. Below probable fault is massive andesitic flow rock with rubbly base, probably a repetition of unit 3 , but may be a different flow.

2. Lapilli tuff, greenish-gray and purplish-gray, rubbly weathering

Hornblende diorite porphyry, probable sill-like intrusive, approximately $50 \mathrm{ft}$ thick.

Diorite porphyry sill with conspicuous large plagioclase phenocrysts and smaller and fewer pyroxene phenocrysts. Approximately $100 \mathrm{ft}$ thick.

1. Lapilli tuff

Total measured thickness of Elkhorn Mountains volcanics (excluding intrusive rocks)

\section{AGE}

No fossils that would permit precise dating have been found in the Elkhorn Mountains volcanics of the map area, but the Slim Sam formation, which contains late Niobrara fossils in its lower part, appears to have been deposited rapidly and to grade upward into the volcanic rocks at some localities, suggesting that the lowest rocks may be as old as the Telegraph Creek formation and possibly as old as very late Niobrara time. The top of the volcanic rocks is an erosion surface and the upper part of the original pile may nowhere be preserved, but on the east flank of Bull Mountain, a few miles south of the area mapped, fossils have been found in marly layers in a volcanic conglomerate that is believed to have been deposited at or near the end of the period of volcanism. Collections from this locality have been examined by T. C. Yen, I. G. Sohn, R. E. Peck, J. B. Reeside, Jr., and R. W. Brown. Yen identified Goniobasis, Physa, and Planorbis, all of undetermined species, and noted fish teeth, fragments of vertebrate bones, and algal coatings on the specimens of Physa and Planorbis. He states (written communication, November 1950) :

The enclosing rock represents a shore deposit of a sizable body of water in which thick growth of filamentous algae occurred in floating masses, and otherwise emergent leafy plants were present close to the shore.

The age of the deposit is less certain at present, possibly somewhere between middle to upper part of the upper Cretaceous. This interpretation is based on negative evidence that the few species of gastropods show no close resemblance to their congeneric forms so far known from the Judith River formation on one hand and those from the Lance and the Fort Union formations on the other.

From the same collection I. G. Sohn (written communication, September 1951 and March 1953) provisionally identified the ostracodes as $C y$ pridea cf. $C$. skeeteri Peck, Cypridea? sp. and Candona? sp. Peck (written communication, May, 1953) did further work on this material, and identified Cypridea cf. C. skeeteri Peck, Cypridea (Pseudocypridina?) sp. and Bairdiocypris sp. He says

* * * the small bisulcate species in this sample closely resembles C. skeeteri Peck and is probably the same species. These forms have been acidized and it is difficult to make a positive identification without characters of the carapace. C. skeeteri (or any other bisulcate Cypridea) has not been found in rocks older than Bear River [formation]. They range (bisulcate forms) into the Eocene. The other Cypridea (probably Pseudocypri$\operatorname{dina}$ ) species in this sample is the largest representative of this genus that $I$ have seen.

Only one species of Cypridea (C. arvardensis (Swain) has been recorded from the Tertiary. This species is not present in the sample.

Considering the close resemblance of the bisulcate species to C. skeeteri and the abundance of Cypridea in the sample, I would judge the age to be Upper Cretaceous, younger than Bear Rirer.

Reeside identified the following forms (written communication, October 1954) collected from the same beds about a mile northward along their strike.

Unio priscus Meek and Hayden

Sphaerium aff. S. recticardinale Meek and Hayden Lioplacodes? sp.

Gyralus sp.

Viviparus sp., large form

He states "This fauna is a late Cretaceous fauna and is most like that reported from the Judith River formation." In the same collections Brown (written com- 
munication, October 1954) identified the following plants: Asplenium tenellum Knowlton, Sequoia reichenbachi (Geinitz) Heer, coniferous seeds, a fruit that resembles Carpites pruni Knowlton, and unidentifiable fragments of dicotyledonous leaves. $\mathrm{He}$ considered these to be ". . . definitely upper Cretaceous plants comparable to those of Judith River age."

At a locality 6 miles west of the locality described above, in beds that lie about 300 feet above the base of the Elkhorn Mountains volcanics at that point, Brown identified Asplenium tenellum Knowlton and Sequoia reichenbachi (Geinitz) Heer, fragments of dicotyledonous leaves and poorly preserved fossil wood. From the same collection Reeside identified Sphaerium recticardinale Meek and Hayden. Brown considers this assemblage to be Upper Cretaceous and comparable to assemblages of Judith River age. Reeside states the Sphcerium ranges through the Late Cretaceous.

Fossil plants have been collected from a third locality, 2 to 3 miles north of the map area, near the top of the preserved volcanic sequence in the trough of the major syncline in that area (H. W. Smedes, unpublished map). R. W. Brown states (written communication, October 1954).

The plants from this locality are few and very fragmentary. In [material collected in 1953] I identified a cone scale Dammara sp. and assigned a Late Cretaceous age to the strata. The 1954 collection has a portion of a coniferous twig that may be Androvettia or Libocedrus; and a fragment that may be the cone scale of a fir Abies, or a small ginkgo leaf. As all of these pieces are fragmentary, I hesitate to make definite identifications. If the first cone scale is really a Dammara, I would have no doubts about its Cretaceous age. If, however, it is merely a battered cone scale of Abies, like the 1954 ginkgolike fragments, then these cone scales plus the Androvettia or Libocedrus would suggest a younger age, Paleocene or a little later.

The paleontologic, stratigraphic, and structural evidence indicates to the authors that the Elkhorn Mountains volcanics are almost certainly wholly Cretaceous in age. But the evidence is insufficient to indicate whether they range in age from very late Niobrara or Telegraph Creek time to an upper limit that cannot be fixed more closely than Juaith River time, or younger, or are restricted in age to Judith River time.

\section{CORRELATION}

Volcanic activity of late Cretaceous and earliest Tertiary age occurred over much of southwestern Montana. The distribution of these volcanic rocks is shown in figure 2. The best known products of this volcanism are the widespread andestitic sediments of the Livingston formation. In general, the primary volcanic rocks from which the sediments of the Livingston were derived are less well known (Lyons, 1944 ; Parsons,
1942). In the type area of the Livingston (Weed, 1893, p. 21), this formation as originally described

consists of a series of beds, in places aggregating 7,000 feet in thickness, composed of sandstones, grits, conglomerates and clays, made up very largely of the debris of andesitic lavas, and other volcanic rocks, and including local intercalations of volcanic agglomerates.

The interpretation of the Livingston formation as a result of later work is summarized by Richards and Prichard (1950, p. 54-55). In this summary they state:

The Livingston formation is composed largely of volcanic material, most of which was transported only a short distance before being deposited in standing waters . . . The Livingston formation is equivalent in age to formations in central Montana from the lower part of the Fort Union formation down to the Eagle sandstone, and in areas west of the Crazy Mountain syncline, down to the 'Dakota' of the early geologists . . . Deposition of rocks now called the Livingston formation was probably continuous from early Montana time and locally from Colorado time into late Montana time in south-central Montana. The base of the Livington formation represents the start of a long period of volcanic activity. Deposition was interrupted by local uplifts along mountain flanks. . . . The Livingston is overlain, probably conformably in much of the area, by the Fort Union formation and the separation of Cretaceous beds from Paleocene beds may be difficult at many places.

Stone and Calvert (1910) showed that the Livingston intertongues with Cretaceous and Paleocene marine sediments, and believed that the base of the Livingston graded into the underlying sediments in the Crazy Mountain syncline, whereas Weed believed that the Livingston was in part unconformable upon lower beds. Peale (1896) mapped the volcanic rocks in the Three Forks area and referred them to the Livingston formation; he showed that they were unconformable on the Kootenai (Dakota formation of Peale). Alexander extended the name Livingston formation into the Whitehall area, and in the formation there included more than 9,600 feet of andesitic flows and tuffs that are continuous with the Elkhorn Mountains volcanics. These he says (p. 74) are unconformable on folded and truncated Madison formation. It appears desirable to assign these volcanic rocks in the Whitehall area to the Elkhorn Mountains volcanic rather than to the Livingston formation, because they are continuous with and generally similar to the Elkhorn Mountains volcanics.

Klemme $^{7}$ in the Sixteenmile Creek area, records about 4,000 feet of Livingston formation resting with apparent conformity on the Eagle sandstone. In the second unit from the bottom, he recognized a Paleocene flora, so that the upper 2,600 to 2,700 feet of his Livingston is of Paleocene age or later. The Paleo-

${ }^{7}$ Klemme, H. D., 1949, Geology of the Sixteenmile Creek area, Montana: unpublished Ph. D. thesis, Princeton Univ. 


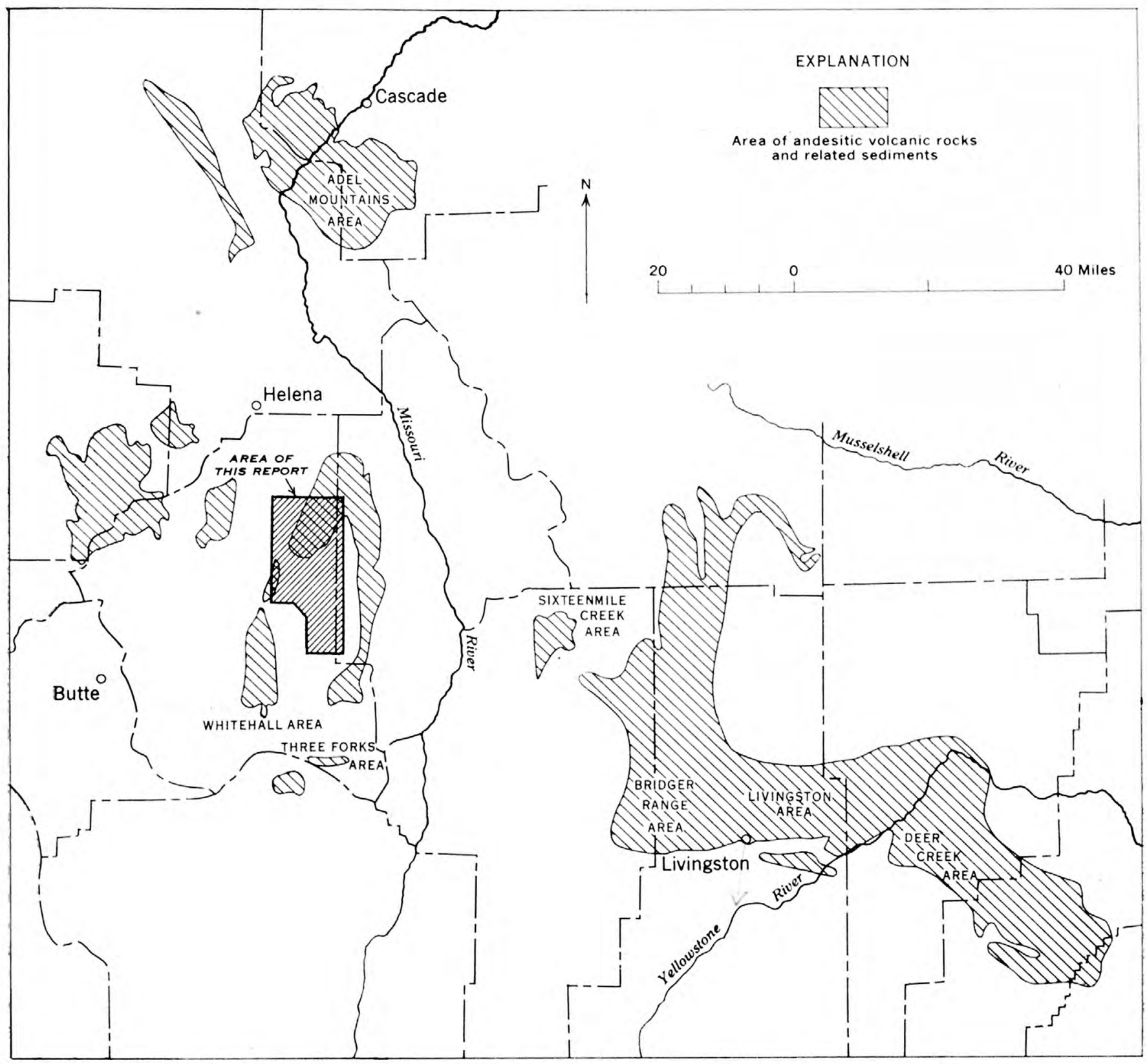

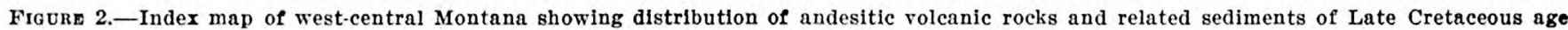
(Rocks of Paleocene age included in Sixteenmile Creek area)

cene flora was found in a unit he named the Maudlow conglomerate lentil, which comprises andesitic volcanic conglomerate and conglomeratic crystal-lithic tuff beds. Klemme, agreeing with Billingsley (1915, p. 35), believes that the Maudlow lentil of Klemme (1949) was derived from "no other source than the lavas of the Elkhorn Mountains." He considers the igneous rocks of the Elkhorn Mountains as an igneous facies of the Livingston and describes the Livingston of the Sixteenmile Creek area as a piedmont facies, derived from the Elkhorn area, and suggests that the Livingston farther to the east is a flood-plain facies.
McMannis ${ }^{8}$ in mapping the Bridger Range shows clearly the intertonguing relationship of the Livingston with all the formations of the Montana group and the early Paleocene.

Parsons (1942, p. 1179), in a detailed study of the coarse pyroclastic rocks near Deer Creek, shows that at least some of the Livingston of that area is directly attributable to local volcanism. He located several small vents and traced the areal extent of material directly associated with one vent, showing that the

${ }^{8}$ McMannis, W. J., 1952, Geology of the Bridger Range, Mont. unpublished Ph. D, thesis, Princeton Univ. 
deposit of ejectamenta from this vent was limited to 3 to 4 square miles in area and a few hundred feet in thickness. He suggests $(1942$, p. 1181) that most of the coarse pyroclastic materials were transported in mudflows or as dry avalanches, and that the finer material was distributed as stream deposits on an alluvial slope. He dated the base of the coarser pyroclastic material as approximately Judith River in age.

Lyons (1944, p. 449) studied a series of volcanic rocks in the northern Big Belt Mountains. These rocks, which he named the Adel Mountain volcanics, consist of 3,200 feet of trachybasalt and basalt agglomerates, conglomerates, and flows and many intrusives ranging from gabbro to quartz monzonite in composition. The Adel Mountain volcanics of Lyons (1944) were deposited unconformably on rocks as young as the Two Medicine formation, which is an equivalent of the Judith River, Claggett, and upper part of the Eagle formations of central Montana, and prior to the main episode of folding. These relations suggest that the Adel Mountain volcanics are younger than the Elkhorn Mountains volcanics.

Available information on age, lithology, and facies relations of Lake Cretaceous and Paleocene voleanic rocks and associated sedimentary rocks is summarized in figure 3.

Billingsley (in Kemp and Billingsley, 1921, fig. 7, p. 465) considered the volcanic rocks in and adjacent to the area mapped as a separate volcanic field, and used the name Elkhorn volcanics. This usage has not been followed by others, and is not recommended here because the name Elkhorn has been preempted as a formation name.

Although the volcanic rocks of the Elkhorn Mountains are partial age equivalents of and compositionally similar to the Livingston formation of the type area, their modes of origin are distinctly different, and separate formation names are needed. The rocks in the Elkhorn Mountains are largely volcanic outpourings; those of the Livingston formation are largely sediments composed of volcanic material, of which some-and perhaps most-was derived from erosion of the Elkhorn Mountains volcanics.

The andesitic sediments of the Livingston formation in and near the type area range in age from Eagle to Paleocene (Stone and Calvert, 1910, p. 551). 'This suggests that if the Elkhorn Mountains volcanics were an important source of the Livingston, they must have been subjected to extensive erosion almost from the start of their accumulation. The upper part of the Slim Sam formation consists largely of andesitic debris also, suggesting that west of the area mapped, vol- canic activity may have commenced during late Niobrara time and that the earliest volcanic debris may have been reworked to form the upper part of the Slim Sam formation. If this interpretation is correct, the upper part of the Slim Sam formation might be considered as the oldest and westernmost known tongue of volcanic sediment similar to that of the Livingston. The Elkhorn Mountains volcanics differ significantly from the Slim Sam formation in that they consist, for the most part, of pyroclastic rocks and related intrusive rocks that accumulated as a volcanic plateau.

\section{RELATIONS TO OLDER ROCKS}

The Elkhorn Mountains volcanic appear to grade downward into the Slim Sam formation in the northeastern part of the map area (pl. 1) and along the northern part of the belt of outcrop lying east of the map area. Westward from the South Fork of Crow Creek, however, the volcanic rocks are unconformable upon successively lower beds, and at Radersburg Pass (pl. 1) they are in contact with the lower black shale unit of the Colorado formation. Farther south and west, in sec. 9, T. 5 N., R. 3 W. (pl. 2), they rest unconformably on beds of Morrison age. At the southeast corner of the map area (pl. 3), volcanic rocks are in contact with the lower black shale unit of the Colorado formation, and at the southern end of the outcrop belt east of the map area, they are in contact with the Morrison formation. About 10 miles south of the area mapped, rocks similar to and probably coextensive with the Elkhorn Mountains volcanics are reported by Alexander to lie with angular unconformity on Madison limestone. In and near the map area the unconformity increases in magnitude to the west and south. Few instances of discordance in dips above and below the unconformity have been detected in the area mapped. Typically units appear to be truncated gradually, thereby suggesting that deformation before the period of volcanism resulted in broad open folds. No evidence that would date the deformation more closely than after the deposition of the upper black shale unit of the Colorado formation and prior to deposition of the Elkhorn Mountains volcanics has been recognized, but the lack of strong discordances and the gradual truncation of beds coupled with local apparently gradational relations suggests that folding, uplift, and erosion was accomplished gradually throughout most of all of the period of deposition of the Slim Sam formation. Locally deformation may have continued during the period of volcanism for there is evidence to suggest that in some places the middle member of the Elkhorn Mountains volcanic rocks rests unconformably on the lower member. 


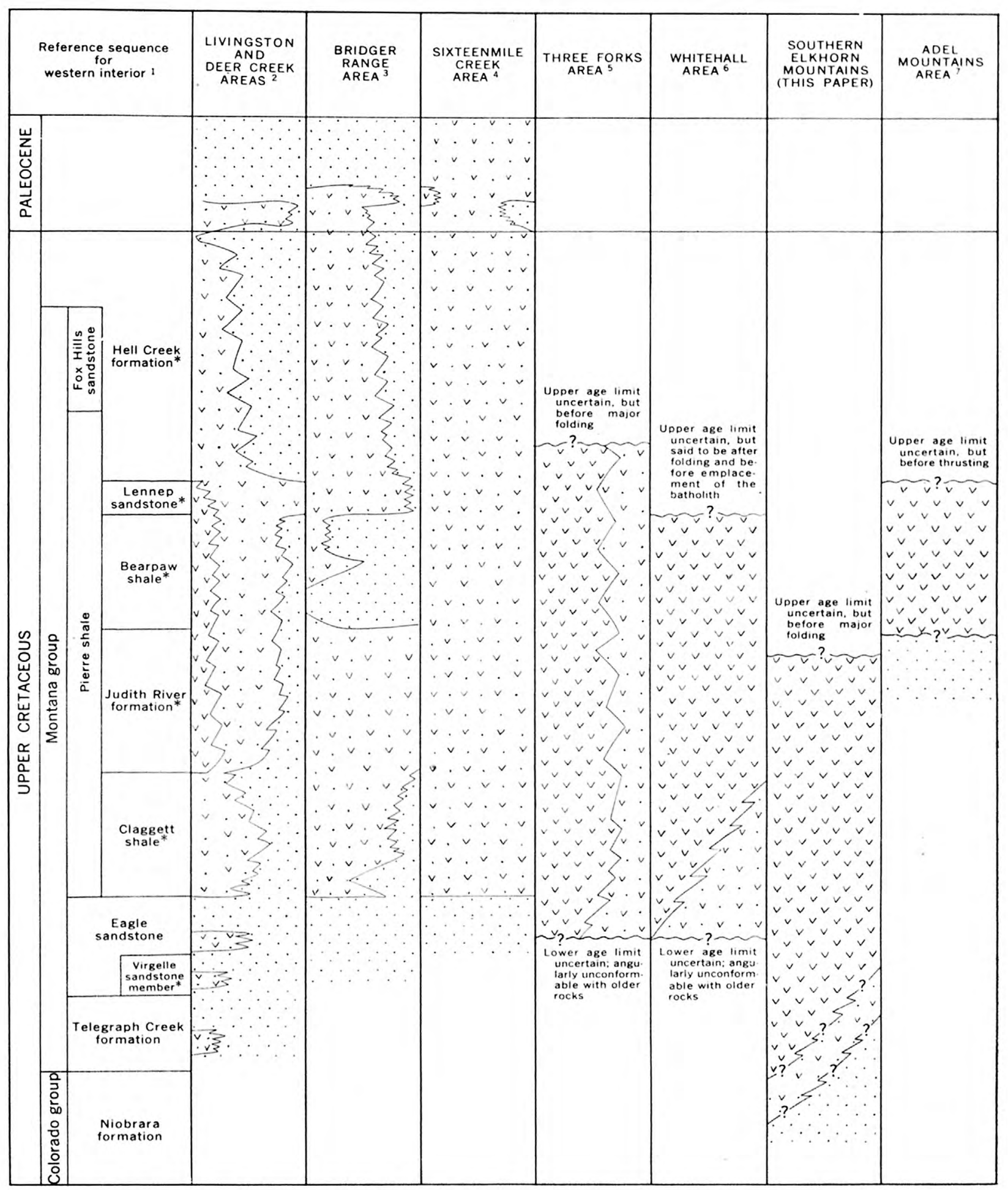

*Added from Cobban and Reeside, 1952, chart 10b, col. 105

1 Cobban and Reeside, 1952

2 Stone and Calvert, 1910; Parsons, 1942

3 McMannis, 1952

4 Klemme, 1950

5 Berry. 1943

6 Alexander, 1950

7 Lyons. 1944

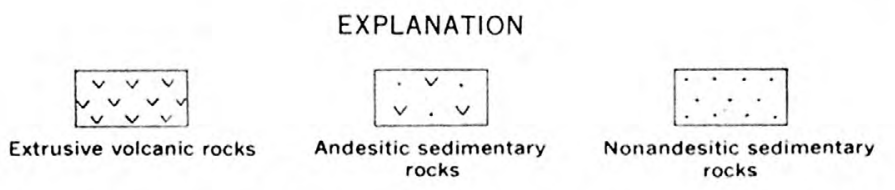

Figure 3.-Generalized stratigraphic distribution of Late Cretaceous and Paleocene volcanic rocks in west-central Montana. 


\section{TERTIARY SYSTEM}

OLIGOCENE AND MIOCENE(?) TUFFACEOUS SEDIMENTS AND GRAVEL

Fine-grained tuffaceous sediments with interlayered conglomerate lenses cover extensive areas in the eastern part of the Devils Fence quadrangle (pl. 2 and $4 B$ ) and underlie younger fan and pediment deposits in the western part. These fluviatile and lacustrine sediments were deposited on a maturely dissected surface and probably completely blanketed it to an elevation of at least 5,000 feet and perhaps to as much as 5,600 feet. They have since been stripped from much of the area and are preserved only in the principal valleys and basins. In the area mapped these sediments are very poorly exposed, and their stratigraphy and structure are very imperfectly known, though they are not strongly folded or faulted. In the central parts of the larger ancient valleys the sequence is probably at least several hundred feet thick. Where exposed, it consists of indistinctly bedded fine-grained cream-colored calcareous rhyolitic vitric tuff, probably of aeolian origin, beds of reworked tuffaceous material with some admixture of older rock detritus, and local layers of gravel or poorly indurated conglomerate composed of pebbles of pre-Tertiary rocks of local origin. In many places areas underlain by this sequence are veneered by gravel. Mammal remains from the tuff at two localities within the area indicate an early Oligocene (Chadron) age and at one locality either an early or late Oligocene age (Jean Hough, written communication).

Along the Boulder River in the southeast part of the Devils Fence quadrangle and continuing south of the area mapped, the tuff sequence is better exposed. It consists of three gradational units; a basal pebbly red mantle as much as 30 or 40 feet thick; a gravelly tuff unit about 100 feet thick and, at the top, a massive lightcolored tuff unit, which is at least 100 feet thick. The massive tuff unit closely resembles the beds of known early Oligocene age. Cobbles and boulders, principally of Upper Cretaceous andesitic volcanic rocks, typically veneer the tuff unit.

In the Townsend Valley east of the area mapped, poorly consolidated sand and gravel deposits of Miocene age lie in valleys eroded in the Oligocene tuffaceous sequence. Some of the unconsolidated gravel veneers on the tuff in the area mapped may be erosional remnants of similar Miocene deposits, although for the most part they probably have been weathered out of conglomerate lenses interbedded in the tuff. Locally, too, the gravel veneers may be remnants of post-Miocene fan deposits.

\section{CONGLOMERATE OF UNCERTAIN AGE}

A few small exposures of deeply weathered conglomerate of uncertain age and origin were observed beneath the unconsolidated fan deposits west of Elkhorn Creek (pl. 2).

The conglomerate contains abundant cobbles of andesitic rock and a few of granitic rock; most are deeply weathered. The sandy matrix of the conglomerate appears to be tuffaceous and may represent material reworked from the Oligocene tuff deposits.

\section{RHYOLITE FLOW OF UNCERTAIN AGE}

A columnar-jointed rhyolite flow of uncertain age along Crow Creek in sec. 30, T. 9 N., R. 1 W. and similar flows along the lower part of Crow Creek valley east of the map area (in secs. 4, 9, and 10, T. 6 N., R. 1 W.) appear to have been extruded in valleys with at least a few hundred feet of relief. One flow east of the map area has a bench cut on it. The age of this bench is believed to be Pleistocene. The rock is dark gray, flow-banded, dense to slightly vesicular, and has sparse phenocrysts of plagioclase feldspar in a cryptogranular dark-colored groundmass. A recently received chemical analysis indicates that the rock is a rhyolite.

\section{FAN DEPOSITS AND PEDIMENT VENEERS}

Coarse-textured fan deposits and finer-grained gravels that are believed to be pediment veneers occupy the broad valleys at the mouths of Elkhorn Creek and Dry Creek. The most conspicuous deposits are west of Elkhorn Creek; here the accumulation is as much as 200 feet thick and consists of coarse bouldery material of possible glacial origin. If so, the deposits are probably of early Pleistocene rather than Tertiary age. Most of the material was probably deposited by Elkhorn Creek, but some may have come from the steep ridge west of Elkhorn Creek. The fan deposits near the mouth of Dry Creek are thinner and cover a smaller area.

South and east of the fan deposits, scattered low outcrops of upper Paleozoic limestone and quartzite protrude above a gravel plain. These outcrops are believed to be the high spots on a pediment surface that probably was cut in post-Miocene time by Elkhorn Creek and Dry Creek. Presumably the fans were deposited later at the margins of these pediments. The gravel plain is believed to be a veneered pediment, but it is not known whether the gravels were deposited during pedimentation or were later washed out from the fans.

\section{QUATERNARY SYSTEM}

Most of the northern third of the map area has been glaciated, and deposits of glacial till, moraine, and ter- 
race gravel mask the underlying bedrock along stream valleys and on many of the higher slopes. These unconsolidated deposits merge with modern stream deposits in the major valleys, and in the nonglaciated part of the area the stream deposits probably include inaterials of both Pleistocene and Recent ages.

\section{GLACIAL DEPOSITS AND GLACIATION}

The central part of the Elkhorn Mountains was extensively glaciated during Pleistocene time. 'Two stages of glaciation can be demonstrated; other stages may also have contributed to the sculpturing of the mountains but, if so, evidence of their activity has been obscured or destroyed by later glaciation and erosion.

The glaciated area is underlain almost entirely by relatively homogeneous andesitic volcanic rocks and quartz monzonite. Only the distal extremities of a few valley glaciers transgressed onto areas underlain by sedimentary rocks. The preglacial topography had attained a stage of early maturity, with the principal streams such as Prickly Pear Creek, Muskrat Creek, Turnley Creek, Elkhorn Creek, Queen Gulch, South Fork Crow Creek, Crow Creek, Tizer Creek and Wilson Creek more or less radiating from a round-topped high area. Another elevated area was the divide between Crow Creek drainage and Beaver Creek and McClellan Creek drainage.

During the earlier glaciation, cirques were excavated at the head of each valley in the highland area, and the ice eventually coalesced to form a broad ice cap that must have covered most of the northern third of the area above 7,000 feet (pl. 1). The excavation of cirques at the maximum stage of glaciation is believed to have occurred at a time when the regional snow line was about 7,500 feet. Several bowl-shaped drainage heads formed near this elevation, notably the broad basin containing the Tizer Lakes, and the heads of Muskrat Creek and Black Canyon. Lobes of ice must have extended down all the existing valleys, but the only recognized deposits left by these lobes are weathered morainal material along the ridge crest between Jenkins Gulch and South Fork Crow Creek, and along the north side of Crow Creek (pl. 1). Distribution of these deposits suggests that they are the remnants of a lateral moraine. The lower valleys of both Crow Creek and South Fork presumably were nearly filled by morainal material as far as their junction, but were later reexcavated, leaving only patches of morainal debris along the ridge crests. The distribution of the older glacial deposits in the southeast quarter of the Clancy quadrangle and the area immediately east of it indicates that the ice lobe descended eastward down Crow Creek and South Fork of Crow Creek to about 5,800 feet. By inference, any lobes extending to the west and north would be able to extend to at least this elevation, if not several hundred feet lower. Additional information may be found when mapping is completed in the mountains north of the present map area.

The younger glacial deposits are more easily interpreted for they retain much of their original form. During this stage (late Wisconsin?) glaciers carved the prominent cirques that occur principally above 8,100 feet. Valley glaciers extended down all the principal valleys, descending to about 6,500 feet on the south and east sides and to 5,700 to 5,300 feet on the north and west sides as marked by terminal moraines at these elevations. An ice sheet covered the Tizer Basin, with valley glaciers extending from it into Black Canyon, Muskrat Creek, Prickly Pear Creek, and Wilson Creek. The Wilson Creek valley glacier was also fed from the north by valley glaciers from Moose Creek, Clear Creek, and Crazy Creek. The glaciers on the southeast, south, and southwest sides of the central high area may not have been connected with the glacier system on the north side, but active valley glaciers occupied the upper parts of Dewey Creek, Hall Creek, Warner Creek, Blacker Creek, South Fork Crow Creek, Queen Gulch, Elkhorn Creek, and Sourdough Creek. The drainage divide just north of the map area supported many glaciers, and within the map area, Eureka Creek and its tributaries contain abundant glacial debris. At the maximum advance of the ice during this stage, valley glaciers from the Wilson and Tizer Creek drainage areas merged and extended down Crow Creek valley nearly to Crow Creek Falls. Well-preserved lateral and terminal moraines are present in the valleys of the South Fork of Crow Creek, Queen Gulch and Muskrat Creek. More-dissected remnants of moraines are in other valleys draining the area to the east, south, and southwest.

As glaciation waned, valley glaciers wasted away, and the Tizer Basin became the site of a stagnant glacier as the retreating ice abandoned successively lower exits. The first exit to be abandoned was the saddle west of Bullock Hill at the head of Wilson Creek, then the saddle at the head of Prickly Pear Canyon. This particular exit must have been used for a relatively long time because a well-developed kame terrace south and east of Bullock Hill (pl. 1) was formed at this stage in the retreat. The next exit to be abandoned was the saddle between Tizer Creek and Little Tizer Creek, west of Manley Park. Below this saddle a kame terrace formed in the lower valley of Tizer Creek during the time that Little Tizer Creek functioned as the sole exit for ice and melt water from the Tizer Basin. 
Melt water from the younger glacier is believed responsible for cutting the gravel-veneered rock benches along both sides of Crow Creek below the falls, and the benches along Eureka Creek. Benches of at least one earlier stage are poorly preserved within the map area, but are better preserved east of the area.

Outwash gravels of the recessional phase were deposited both as terrace gravels on the benches and as fans where the principal streams emerged from the mountains. Till deposits of approximately latest glacial age cover much of the Tizer Basin, and mask the bedrock on the higher slopes sporadically. Most semiflat spots within the glaciated part of the map area are characterized by undrained depressions and boggy terrain. Bogs are common on the slopes as well as in the valleys, and morainal ponds and lakes dot the landscape. Vegetation is generally a dense growth of lodge-pole pine and alpine plants. The combination of bogs, boulders, and dense vegetation makes walking difficult and other forms of transportation almost impossible.

Evidence of severe climate is preserved in small features that are typically associated with perennially frozen ground. Stone nets, stone stripes, and felsenmeer have been observed, especially in the vicinity of Elkhorn Peak. Ridge tops that separated adjacent valley glaciers were sharpened. Two excellent examples are the north rim of Black Canyon and the east wall of Anderson Gulch.

In summary, glaciation of the area is almost solely responsible for the present degree of dissection of the higher parts of the southern Elkhorn Mountains, and has left a mantle of glacial deposits of several different physiographic types and of variable thickness over many of the slopes and most of the valleys.

\section{LANDSLIDE DEPOSITS}

The steep-walled valleys formed by glacial scour have been modified since the retreat of the glaciers by accumulations of talus and stream gravels, and more spectacularly by many small landslides. Only the larger landslide deposits have been mapped, but there are many small areas of jumbled blocks of locally derived rock beneath crescentic scars. A slide just east of the map area along the south wall of Crow Creek valley below the mouth of South Fork is younger than the terrace gravels.

\section{Alluvium}

Recent alluvium is present in most stream valleys, and as bog-, marsh-, and pond-filling deposits throughout the glaciated area. Inasmuch as the retreat of the glaciers is a relatively recent event, the incompletely developed drainage offers many local sites for deposi- tion. Despite the large amount of unconsolidated debris available for transport and the high stream gradients, the streams of the higher areas are crystal clear, except during short periods of high water in the spring, and flow on a bed of boulders and cobbles with little interstitial gravel and sand.

\section{FAN DEPOSITS}

Small fan deposits formed later than the terraces are present at the mouths of most tributary streams as they enter the principal valleys; especially good examples are along the valley of Crow Creek. Larger fan deposits at the mouths of the principal creeks may be in part preglacial, in part of Pleistocene age, and in part of Recent age. At present these larger fans are being dissected by the modern streams, and only the fans of the tributary intermittent streams are being constructed.

\section{INTRUSIVE ROCKS}

The intrusive igneous rocks of the area comprise a variety of types, both mineralogically and texturally. With the possible exception of the thick sill in the Greyson shale, all are younger than the Colorado formation and, with the exception of a few narrow felsite dikes of uncertain age, all are probably older than early Oligocene. These rocks are herein divided into two groups, primarily on the basis of structural relations and secondarily on the basis of composition and fabric. Rocks of the older group were intruded in part, if not wholly, prior to the main episode of folding. They consist principally of diorite and diorite porphyry and are closely similar chemically and mineralogically to the Upper Cretaceous Elkhorn Mountains volcanics and were probably emplaced throughout the period of volcanism. Local unconformities at the base of the volcanic sequence suggest that this igneous activity may have been initiated by local compressional deformation. The main episode of Laramide folding and faulting followed this period of dioritic-andesitic igneous activity and was succeeded by the emplacement of the younger group of igneous rocks, which are for the most part quartz-bearing phanerites, but range from gabbro to alaskitic granite and aplite. The Boulder batholith, which is composed predominantly of quartz monzonite, is the principal representative of this group.

Certain mineralogical and chemical similarities suggest that the igneous rocks of the older and younger groups may be genetically related.

\section{OLDER INTRUSIVE ROCKS}

Rocks assigned to the older group range in composition from monzonitic to gabbroic, but most are dioritic. In fabric they range from moderately coarse grained. 


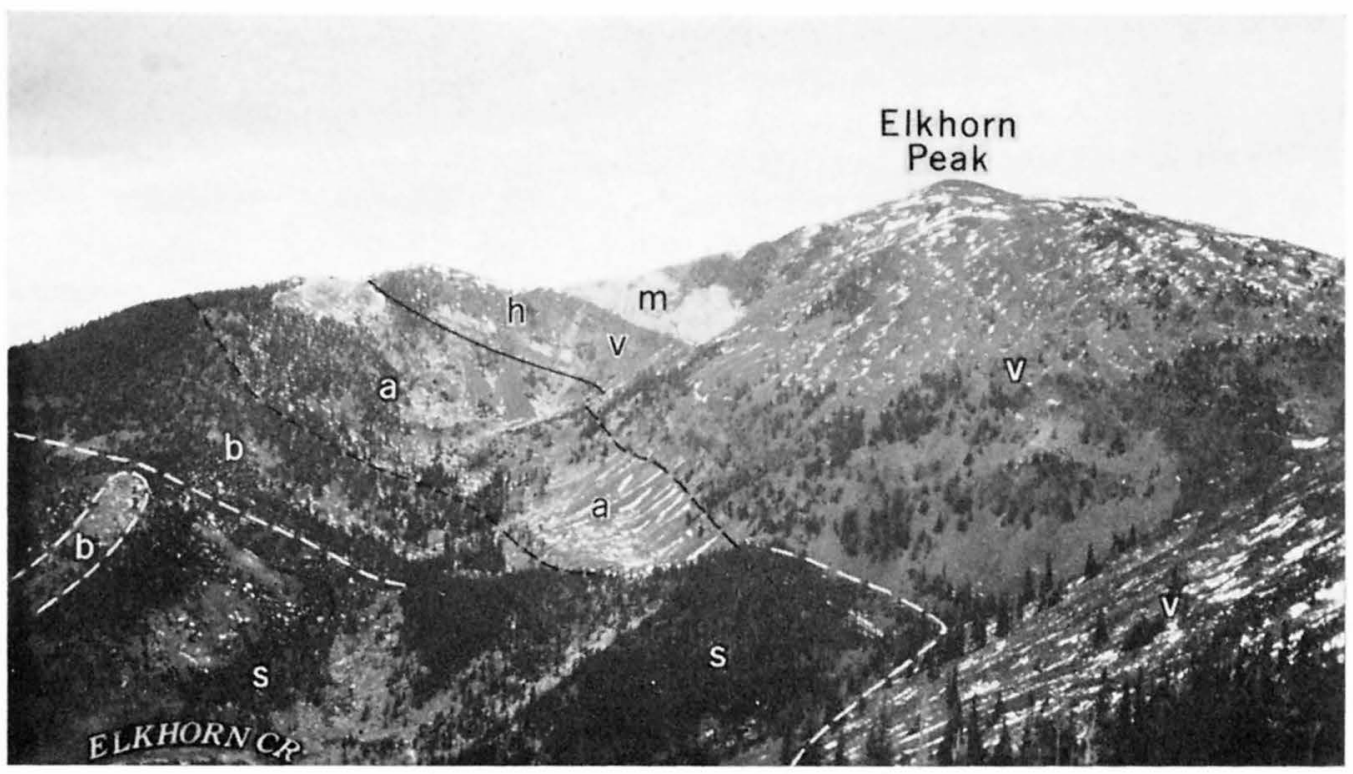

A. RELATIONS BET WEEN ELKHORN MOUNTAINS VOLCANICS, CRETACEOUS SEDIMENTARY ROCKS, AND ROCKS OF THE BOULDER BATHOLITH, ELKHOR PEAK

A sill-like offshoot from the Boulder batholith comprising alaskite (a) and quartz monzonite (b) lies between Elkborn Mountain. volcanics (v) and Cretaceous sedimentary rocks (s). Near the base of the voleanic rocks are a thin unit of calcrilicate hornfels (h) and a lens of marble (m) 100 feet thick. The bedded rocks dip about 25 degrees eastward. The upper contact of the sedimentary rocks is partly concealed behind the wooded hill in the foreground. Glacial debris covers the valley bottoms and the lower parts of the slopes.

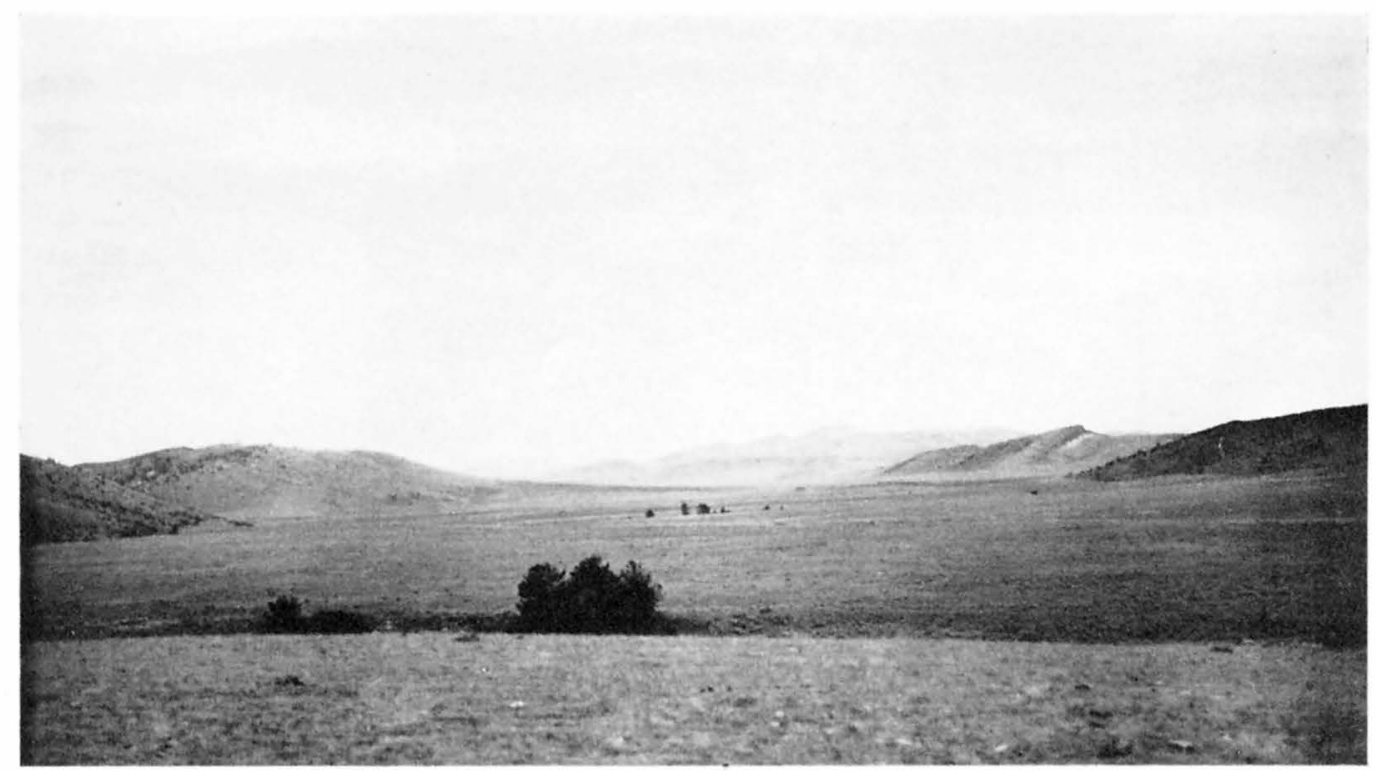

B. BROAD VALLEY FILLED WITH TERTIARY VOLCANIC SEDIMENTARY ROCKS

Hogbacks are lower Paleozoie rocks. Lower part of the ridge at the left is Lodgepole limestone and upper part in Vlission Canyon limestone. 

equigranular to very fine grained porphyritic, but most are fine-grained porphyry. Only a few contain significant amounts of primary quartz. As a group they are closely similar chemically and mineralogically to the flows and fragmental rocks that comprise the Elkhorn Mountains volcanics, and fragments of the intrusives are important components of the volcanic breccias. These rocks are most common as sills or slightly discordant sill-like bodies in Kootenai and older sedimentary rocks, as moderately large partially concordant but dominantly discordant plutons in post-Kootenai sedimentary rocks (most of which are just east of the area mapped), and as dikes, sills, and small plugs in the volcanic rocks; two small stocks, each with irregular silllike offshoots, cut Paleozoic rocks.

These intrusions favor the shaly formations. The sills, at least, were emplaced by pushing apart or dilating the preexisting rocks. In every case where reliable measurements can be made, the formations are thickened by the amount of interlayered igneous rock. The most striking proof of dilation is given by the sills in the limestone near the top of the Kootenai formation. This unit, which nowhere exceeds 35 or 40 feet in thickness, is at several localities split and invaded by sills as much as 100 feet thick.

The sills are believed to have been folded with the enclosing bedded rocks, for it does not seem likely that so many bodies would conform to bedding, whether the bedding is horizontal, inclined, or vertical, if the sills had been emplaced after the enclosing rocks had been folded, nor does it seem probable that the sills would have been able to dilate the enclosing rocks had they been folded into moderately tight anticlines and synclines prior to intrusion. It does seem likely, however, that intrusion may have coincided with the early stage of folding, for during this stage, while the rocks were horizontal or only gently arched, compressive forces might tend to form zones of weakness along certain favorable beds into which magma might be squeezed.

Although no clear evidence has been found, it seems highly probable that the larger diorite porphyry plutons east of the area mapped were also emplaced prior to the main episode of folding, and that some or all of them may be the consolidated remnants of near-surface reservoirs from which andesitic volcanic rocks were extruded. Many of these plutons have a more or less concordant base and an irregular discordant top. The relative ages of the several different petrographic types assigned to the older group of intrusives is not known.

\section{DIORITE PORPHYRY AND RELATED ROCKS}

Many of the sills and all of the plutons mentioned above are diorite porphyry and related rocks. These rocks are gray to greenish gray and contain phenocrysts of plagioclase and hornblende or pyroxene, or both. The size and number of phenocrysts, the ratio of plagioclase to mafic minerals, the relations of phenocrysts to groundmass, and the grain size and texture of the groundmass vary within wide limits. These rocks are most common in the southeastern part of the Clancy quadrange (pl. 1) and the northeastern part of the Devils Fence quadrangle (pl. 2) and in a north-trending belt a mile or two to the east.

Most of the rocks in this group are porphyritic finegrained phanerites (diorite porphyry) or aphanites (andesite porphyry) of dioritic composition in which the fabric is seriate and in which phenocrysts nearly equal or predominate over groundmass. The texture of the groundmass in different rocks ranges from granular to felted and, less commonly, is intergranular or intersertal. Plagioclase of intermediate composition is the most abundant and characteristic mineral and occurs as phenocrysts in most of the rocks. Lustrous black hornblende is also plentiful and forms the predominant phenocrysts in many of the plutons and in some sills. Dark-green or black pyroxene is common in some intrusives, especially those that cut the Elkhorn Mountains volcanics. Potash feldsparprobably orthoclase-and quartz are subordinate minerals in most of the rocks, but in some they are sufficiently common to justify the names quartz diorite porphyry, syenodiorite porphyry, monzonite porphyry, granodiorite porphyry, or their aphanitic equivalents. Small clear apatite crystals and grains of opaque iron ores occur in most of the rock, and sphene was observed in a few. Epidote may be a primary mineral in some rocks, but for the most part has been formed by alteration of other minerals. Specific gravities of rocks assigned to this group range from 2.69 to 2.79 .

Most of these rocks are at least mildly altered and many are so intensely altered that the primary minerals cannot be determined. Typically phenocrysts are more altered than groundmass. Hornblende appears to be most susceptible to alteration. In many slides it is partly or wholly altered to pale-green chlorite with which calcite and epidote may be intergrown. The feldspars are altered to aggregates of sericite flakes and less commonly to a brown opaque dust or to aggregates of epidote or clinozoisite, calcite, and albite. In some rocks, mosaics of fine-grained quartz, locally containing intergrown orthoclase or epidote, are sporadically present. An intensely altered local marginal facies of the small stock in secs. 29 and 32, T. 5 N., R. 1 W. (pl. 2) consists of about 60 percent granular epidote intergrown with 40 percent sutured quartz and a few shreds of chlorite. 
Intense albitization was observed only in the thick sill in the Greyson shale (pl. 2), a typical specimen of which appears to have originally been a fine-grained monzonite or diorite porphyry, but is now composed of about half microgranular groundmass and half phenocrysts; the groundmass consists of feldspar-probably both albite and orthoclase-and possibly very subordinate quartz; the phenocrysts are altered to albite, penninite, epidote, or calcite, or to intergrowths of two or more of these minerals. The distinctive type of alteration suggests that this thick sill may not be related to the other diorite porphyry intrusives in the area, but rather may have been intruded and altered in Precambrian time.

\section{HORNBLENDE LAMPROPHYRE}

The hornblende lamprophyre is a rock of unique appearance that forms a few sills in the Wolsey and Park shales. The only sill that was large enough to plot on the geologic map is at the base of the Park shale between Johnny Gulch and Dahlman Gulch (pl. 2); it has a maximum thickness of 75 feet and can be traced for 2 miles. The unweathered rock consists of a darkgreenish-gray aphanitic groundmass in which are embedded lustrous greenish-black hornblende phenocrysts (10 to 30 percent) that have maximum dimensions of 2 centimeters in length and 3 millimeters in breadth. Locally the phenocrysts are grouped into crude rosettes. Weathered surfaces of the rock are particularly conspicuous, for on them the color contrast between phenocrysts and groundmass is greatest.

Microscopically the lamprophyre is seen to have a distinct hiatal fabric with hornblende phenocrysts averaging 5 millimeters in length imbedded in a felted to granular intergrowth of plagioclase laths, hornblende prisms and shreds, and orthoclase anhedrons that are molded around the other two minerals; the minerals of the ground mass average less than 0.1 millimeter in maximum dimension. The hornblende, both as phenocrysts and in the ground mass, is partly altered to pale-green chlorite and calcite; the feldspar in the ground mass is also partly replaced by calcite. Specific gravities of two specimens, one containing about 10 percent and the other about 30 percent hornblende phenocrysts, are 2.75 and 2.81 respectively.

The rock is similar in composition and is almost certainly genetically related to the previously described andesitic and fine-grained dioritic rocks, but the strikingly hiatal fabric, the relative abundance of hornblende-much of it as phenocrysts, and the lack of feldspar as phenocrysts mark it as a lamprophyre in the nongenetic sense used by Knopf (1936, p. 1748-1749).

\section{BASALT AND RELATED ROCKS}

Sills and sill-like bodies of very dark gray or greenish-black rocks that have a considerable range in grain size and fabric occur principally in the gently folded Cretaceous sedimentary rocks in the southeastern part of Clancy quadrangle (pl. 1). A typical example is the body at the top of the Kootenai formation near the head of the East Fork of Dry Creek. These rocks consist essentially of plagioclase in the andesine-bytownite range, a monoclinic pyroxene, and olivine. Small amounts of hornblende, biotite, a potash or potashsoda feldspar, and quartz are present in a few. Most of the rocks are porphyritic. Phenocrysts range from sparse to abundant and are predominantly pyroxene. The groundmass ranges from fine-grained (basalt porphyry) to medium-grained (gabbro porphyry). Texture of the ground mass ranges from finely granular or poorly felted intergrowths to intergranular. The finer grained part of two rocks examined may be devitrified glass. Specific gravities of samples tested range from 2.81 to 3.00 .

\section{YOUNGER INTRUSIVE ROCKS}

Intrusive rocks assigned to the younger group are those that were emplaced after the enclosing rocks were folded. They comprise the granitic rocks that form the Boulder batholith and a number of petrographically similar stocks; the gabbro-diorite, diorite, dioriteporphyry, and quartz diorite porphyry that form stocks near Elkhorn; and the peculiar assemblages of normal and abnormal igneous rock types that form a few small composite plutons in the northern half of the Devils Fence quadrangle.

\section{STOCKS NEAR ELKHORN}

The oldest postdeformation intrusive rocks of the area are thought to be the several types of dioritic and gabbroic rocks that form stocks near Elkhorn (pl. 1). The relative ages of these stocks have not been established, but all are older than the elongate northwestward-trending body of granodiorite porphyry and the rocks of the Boulder batholith, and all may be genetically related. The granodiorite porphyry is tentatively considered to be older than the rocks of the batholith.

\section{BLACK BUTTE STOCK}

The very irregular intrusive body northwest of Elkhorn was named the Black Butte stock by Barrell (in Weed, 1901, p. 513-516). It consists of several more or less gradational facies of gabbro and diorite ranging from relatively fine grained to relatively coarse grained. Barrell (1901, p. 513-516) describes 
the mineral composition of typical rocks from the stock and related bodies and lists the chemical analysis of one sample of gabbro. In summary he states (1901, p. 513-514) that

the material of this intrusion is typically a gabbro, but shows considerable variation in composition, leaning in some places toward the anorthosites, in others toward the pyroxenites, and passing in the outlying dikes into diorites.

In the present study representative samples of the two principal rock types in the stock were selected for chemical analysis and microscopical examination. One of these is a medium- to coarse-grained gabbro that consists of 40 to 50 percent labradorite, 20 to 25 percent augite, 15 to 20 percent pale-green hornblende, at least part of which replaces augite, about 10 percent biotite, 5 percent magnetite, and 1 percent or less of apatite and quartz. A chemical analysis of this rock is shown in column $50 \mathrm{KC}-24$ of table 1 . The other rock is a medium-grained almost equigranular diorite that consists of about 60 percent calcic andesine, 10 to 15 percent each of biotite and hornblende, 1 to 2 percent each of augite, magnetite, and epidote, and about 10 percent quartz of late crystallization. A chemical analysis of this rock is shown in column $50 \mathrm{KC}-25$ of table 1 .

TABLE 1.-Chemical analyses of igneous rocks from vicinity of
Elkhorn, Mont.

[Samples $50 \mathrm{KC}$-21-25 inclusive are rapid-method analyses (Shapiro and Brannock, 1956) by S. M. Berthold and E. A. Nygaard, U. S. Geological Survey]

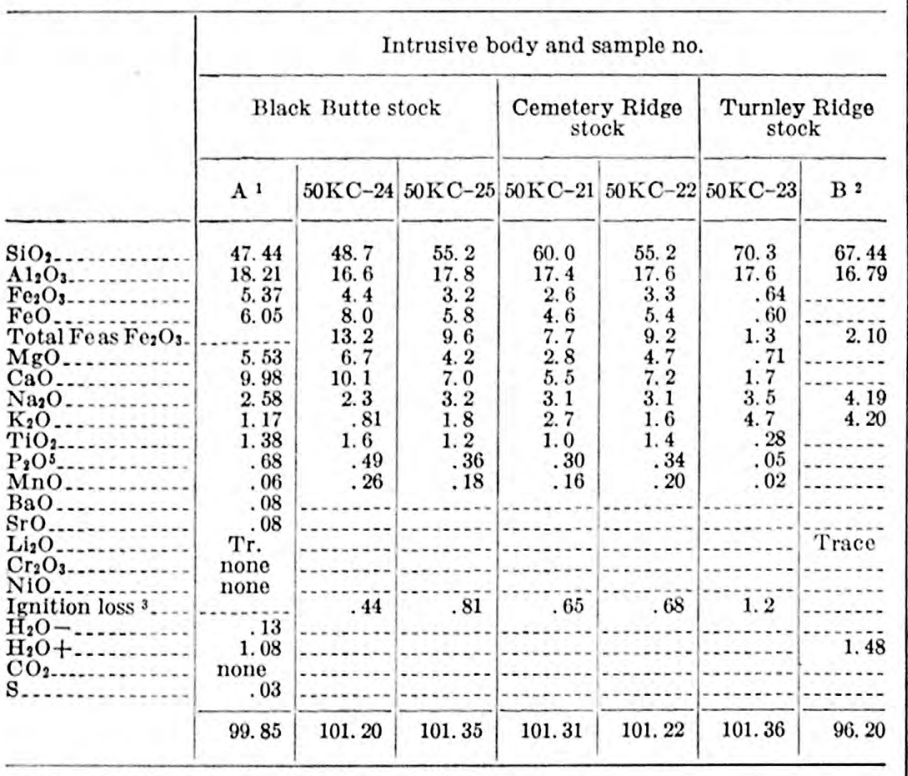

1 Weed, 1901, table on p. 514.

3 Includes gain due to oxidation of $\mathrm{FeO}$.

$$
\text { Sample no. Rock type }
$$

A Normal gabbro.

Aabbro.

25 Biotite-hornblende diorite.

21 Coarse-grained biotite-hornblende diorite.

22 Fine-grained biotite-hornblende diorite.

${ }_{23}$ Granodiorite(?) porphyry.

B Quartz-diorite porphyry.
CEMETERY RIDGE STOCK

The intrusive body east of Elkhorn was named the Cemetery Ridge stock and described by Barrell (in Weed, 1901, p. 516-518). He identified several widely different rock types in and around the stock, but was unable to determine the relations between them. The present study indicates that the stock proper, insofar as can be determined from scattered poor exposures, consists of rather homogeneous medium-grained gray diorite that is almost certainly genetically related to the dioritic facies of the Black Butte stock (compare analyses $50 \mathrm{KC}-22$ and $50 \mathrm{KC}-25$ of table 1$)$. It is probable that these two stocks are near-surface expressions of a larger subjacent intrusive of gabbro or diorite. In thin sections of the two freshest specimens that could be obtained from the stock the mineral composition is as follows:

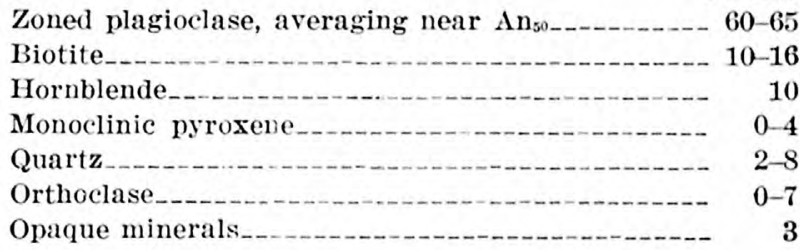

Chemical analyses of a relatively coarse grained and a relatively fine-grained variety of this diorite are listed in columns 50KC-21 and 50KC-22 of table 1.

Descriptions of gabbroic rock from the margin of the stock and of several dikes that occur in close association with the stock are given by Barrell (in Weed, 1901, p. $517-518)$.

\section{STOCK OF FINE-GRAINED DIORITE}

A small stock of dark-greenish-gray fine-grained diorite at the junction of Elkhorn and Turnley Creeks (pl. 1) megascopically resembles some of the thermally metamorphosed andesitic volcanic rocks of the region, and it was mapped as such by Weed (1901, pl. 45). The present mapping, however, has demonstrated that this body cuts a postvolcanism fault, and therefore is younger than the volcanic rocks. Microscopically, it consists of intermediate plagioclase $\left(\mathrm{An}_{45-50}\right)$, having crude to moderately well-defined alinement, with green to bluish and yellowish-green hornblende, and brown biotite, some occurring as small flakes or aggregates of flakes replacing hornblende. A specimen collected near the contact with a body of diorite porphyry contains common interstitial quartz and orthoclase(?) and veinlets and irregular clusters of ragged bluish-green hornblende with sparse intergrown biotite. Genetically the stock of fine-grained diorite may be related to the Black Butte stock and the Cemetery Ridge stock. 


\section{STOCK OF DIORITE PORPHYRY}

A small body of diorite porphyry between Elkhorn Creek and Queen Gulch near their confluence (pl. 1) was described by Barrell (in Weed, 1901, p. 531-533) as a laccolith. The present mapping suggests rather that it is an irregular stocklike body that was emplaced along a preexisting fault. The rock is a relatively homogeneous prophyry consisting of a gray fine-grained groundmass of quartz, sodic plagioclase, and orthoclase in which are imbedded as much as 40 percent phenocrysts of zoned plagioclase and a few percent of hornblende and biotite, much of which is aggregated into small clusters. Most of the hornblende has a peculiar bluish-green pleochroism, similar to that of the hornblende in the marginal part of the fine-grained diorite. Barrell described in detail the microscopic features of this rock. Petrographic similarity of the diorite porphyry to parts of the Turnley Ridge stock that contain few or no quartz phenocrysts suggests that these two intrusive bodies are genetically related.

\section{TURNLEY RIDGE STOCK}

An irregular branching, roughly $Y$-shaped, body of granodiorite or quartz monzonite porphyry extends from the Queen mine (pl.2) northwestward to the confluence of Turnley and Sourdough Creeks (pl. 1), cutting across Precambrian and early Paleozoic sedimentary rocks and earlier dioritic intrusions. Its relationship to the quartz monzonite of the Boulder batholith, with which it is in unexposed contact, has not been established. This body was named the Turnley Ridge stock and described by Barrell (in Weed, 1901, p. 533535). Typical specimens of the rock consist of a lightcolored very fine grained groundmass with from 30 to 60 percent phenocrysts of feldspar and quartz. Under the microscope the groundmass is seen to consist of a very fine grained granular intergrowth of quartz and feldspar and the phenocrysts of moderately to strongly altered but recognizable oligoclase or andesine, highly altered indeterminate feldspar, quartz, rare orthoclase, and very rare aggregates of biotite flakes or hornblende shreds. One partial and one complete chemical analysis of specimens from this stock are shown in table 1.

In some specimens much of the quartz and a little of the feldspar is brecciated and forms angular fragments and shards that range in maximum dimensions from a few hundredths of a millimeter to a few millimeters. In places the rock is also cut by numerous thin stringers of fine-grained quartz. Emplacement of the porphyry mass has been controlled, at least in part, by a preexisting zone of faulting. The above mentioned features of the rock suggest that there may have been recurrent movement along this zone during and immediately subsequent to the emplacement of the intrusive mass.

Barrell (in Weed, 1901, p. 535) noted that no quartz phenocrysts are present in one part of the stock. This observation together with the broken and dragged condition of many of the quartz phenocrysts suggested to him that the stock may have been formed by more than one surge of intrusive material and that the later accessions carried along quartz that had crystallized prior to intrusion and became "pulled apart and sheared" by movement of the "viscid medium." Origin of the stock of diorite porphyry between Elkhorn Creek and Queen Gulch (pl. 1) as an early surge of magmatic material from the same source as the magma that formed the Turnly Ridge stock is compatible with this theory.

\section{ROCKS OF THE BOULDER BATHOLITH}

QUARTZ MONZONITE, GRANODIORITE, AND RELATED ROCKS

A part of the Boulder batholith occupies the northwestern part of the area mapped (pls. 1 and 2). The rocks of the batholith in this area are medium- to coarsegrained quartz monzonite and granodiorite and comprise three intergradational varieties, here designated normal, mafic, and porphyritic. On the map the varieties have not been delimited.

The normal quartz monzonite and granodiorite, which is the predominant rock of the batholith in the area mapped, is a medium- to coarse-grained gray phanerite composed of plagioclase near $\mathrm{An}_{40}$, potash feldspar, quartz, biotite, hornblende, and small amounts of opaque minerals, sphene, apatite, and, rarely, zircon, allanite(?), and monazite(?). In the specimens studied microscopically, the ratio of plagioclase to orthoclase ranges from about $2: 1$ to $1: 2$. Typically plagioclase is more abundant than potash feldspar and in a few specimens, the ratio of plagioclase to potash feldspar exceeds 2 to 1 . Quartz forms about 20 percent of most samples, biotite and hornblende in different proportions form 15 percent, and, except for sparse accessory minerals, and in some rocks augite, the remainder of the rock is feldspar. Chemical analyses of normal quartz monzonite are shown in table 2.

Plagioclase and the mafic minerals commonly have one or more crystal faces; potash feldspar, part containing microperthitic intergrowths and part containing faint microcline twinning, seldom has crystal faces; and quartz is almost invariably anhedral or molded around grains of other minerals. Most specimens examined are more or less altered, in part due to deuteric processes and in part to weathering. The potash feldspar is clouded by a very fine grained aggregate, probably of kaolin; the plagioclase is more or less replaced 
by sericite or by aggregates of epidote or less commonly clinozoisite, calcite, and sodic-plagioclase; and the ferromagnesian minerals are altered to chlorite, epidote, and one or more opaque minerals commonly accompanied by sphene.

TABLE 2.-Chemical analyses of rocks of Boulder batholith near Elkhorn, Mont.

[Samples 50KC-17-20 inclusive are rapid-method analyses (Shapiro and Brannock, 1956) by S. M. Berthold and E. A. Nygaard, U. S. Geological Survey]

\begin{tabular}{|c|c|c|c|c|c|c|c|}
\hline & \multicolumn{7}{|c|}{ Sample No. } \\
\hline & $50 \mathrm{KC}-18$ & $112^{1}$ & $50 \mathrm{KC}-17$ & $50 \mathrm{KC}-19$ & $50 \mathrm{KC}-20$ & $109^{2}$ & $142^{2}$ \\
\hline $\begin{array}{l}\mathrm{SiO}_{2} \\
\mathrm{Al}_{2} \mathrm{O}_{3} \\
\mathrm{Fe}_{2} \mathrm{O}_{3} \\
\mathrm{FeO}\end{array}$ & $\begin{array}{r}67.0 \\
15.3 \\
2.0 \\
2.4\end{array}$ & $\begin{array}{r}64.31 \\
15.44 \\
2.43 \\
2.58\end{array}$ & $\begin{array}{r}60.2 \\
15.6 \\
2.3 \\
3.9\end{array}$ & $\begin{array}{r}75.8 \\
12.7 \\
.90 \\
.82\end{array}$ & $\begin{array}{r}79.2 \\
12.0 \\
.36 \\
.00\end{array}$ & $\begin{array}{r}76.26 \\
12.94 \\
0.69 \\
0.13\end{array}$ & $\begin{array}{r}74.61 \\
13.36 \\
0.83 \\
0.36\end{array}$ \\
\hline $\begin{array}{c}\text { Total Fe as } \\
\mathrm{Fe}_{2} \mathrm{O}_{3} \ldots \ldots . . .\end{array}$ & & & 6.6 & & 0.36 & & \\
\hline $\mathrm{MgO}$ - & 2.2 & 2.21 & $\begin{array}{l}4.0 \\
4.6\end{array}$ & 0.84 & 0.71 & 0.17 & 0.35 \\
\hline $\mathrm{CaO}$ & 3.6 & 4. 22 & 4.9 & 1.0 & 0.36 & 1. 10 & 1.35 \\
\hline $\mathrm{Na}_{2} \mathrm{O}$ & 2. 8 & 2. 71 & 2.8 & 2.9 & 3. 0 & 2.73 & 2. 49 \\
\hline $\mathrm{K}_{2} \mathrm{O} \ldots$ & 4. 3 & 4.09 & 4.0 & 5.1 & 5.4 & 5.26 & 5.70 \\
\hline $\mathrm{TiO}_{2}$ & 0.73 & & 0.70 & 0.39 & 0.14 & 0.11 & 0.11 \\
\hline $\mathrm{P}_{2} \mathrm{O}_{3}$ & 0.14 & 0.22 & 0.34 & 0.03 & 0.00 & 0.06 & 0.06 \\
\hline Mno .- & 0.09 & Trace & 0.12 & 0.07 & 0.01 & Trace & Trace \\
\hline $\begin{array}{l}\mathrm{H}_{2} \mathrm{O}-\ldots \ldots \\
\mathrm{H}_{2} \mathrm{O}+\ldots \ldots\end{array}$ & & $\begin{array}{l}0.19 \\
0.79\end{array}$ & 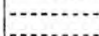 & & & $\begin{array}{l}0.17 \\
0.43\end{array}$ & $\begin{array}{l}0.19 \\
0.42\end{array}$ \\
\hline Ignition loss 3 & 0.47 & & 0.77 & 0.47 & 0.26 & & \\
\hline $\mathrm{CO}_{2} \ldots$ & & None & & & & & - \\
\hline $\mathrm{Cr}_{2} \mathrm{O}$ & & $\begin{array}{l}\text { Trace } \\
\text { None }\end{array}$ & & & & & \\
\hline$\cdots$ & & 0.07 & & 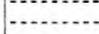 & $\cdots$ & 0.07 & 0.10 \\
\hline $\mathrm{LH}_{2} \mathrm{O}$ & & Trace & - & 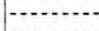 & 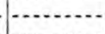 & & \\
\hline $\mathrm{N}_{2} \mathrm{O}_{-}$ & & $\begin{array}{l}\text { Strong } \\
\text { trace }\end{array}$ & & & & & \\
\hline & 101 & 99. 97 & 101 & 101 & 101 & 100.13 & 99.93 \\
\hline
\end{tabular}

1 Weed, 1902 , p. 536

2 Weed, 1902, p. 540

3 Includes gain due to oxidation of $\mathrm{FeO}$.

$50 \mathrm{KC}-18$. Blotite-hornblende granodiorite normal variety. NE1/4 sec. 5 . T. 6 N., R. $3 \mathrm{~W}$. 112. Quartz monzonite ("type of the batholith") at Elkhorn, 1 mile from contact of 112. Quartz monzo

the batholith.
50KC-17. Hornblende monzonite, mafic variety. Between Prickly Pear and Weimar Creeks.

$50 \mathrm{KC}-19$. Medium-coarse-grained alaskitic granite from the dike at boundary between sec. 1 and 2 , T. 6 N., R. $3 \mathrm{~W}$.

$50 \mathrm{KC}-20$. Medium fine-grained alaskite near west margin of "dumbell-shaped" intrusive in $\mathrm{SW} 1 / 4$ sec. $36, \mathrm{~T} .7 \mathrm{~N} ., \mathrm{R} .3 \mathrm{~W}$.

109. A plite from middle of large intrusion north of Black Butte.

142. Aplite, from eastern side of same intrusion as $109,2,500$ feet north of Black Butte.

The mafic variety of quartz monzonite or granodiorite contains as much as 30 percent combined biotite, hornblende, and iron oxides and in a few specimens, sparse augite. Its texture ranges from medium-grained to coarse-grained to porphyritic. The porphyritic rocks of the mafic variety are distinctive in that the dark minerals tend to occur as aggregates half an inch across, in which ragged crystals of biotite and hornblende are intergrown with subordinate feldspar. These glomerophyric aggregates and discrete subhedral plagioclase crystals are set in the medium- to fine-grained groundmass composed of quartz, feldspar, and small biotite flakes.

Although the distribution of the mafic variety was not mapped, rocks of this type have been observed at three places at or near the border of the batholith and in a few places a mile or more from the margin, though perhaps these rocks were closer to the roof of the batholith before it was eroded away. In the vicinity of the
Elkhorn Peak Iron mine (pl. 1, no. 1) rocks of the mafic variety in the marginal part of the batholith clearly are the product of reaction between andesitic volcanic rocks and quartz monzonite magma, for here andesitic rocks grade nearly imperceptibly from recrystallized rocks of hornfelsic or granulitic fabric through fine- and medium-grained diorite that contains relict fragments of andesitic rocks into mafic granodiorite or quartz monzonite that contains many xenoliths and finally into normal quartz monzonite that contains a few mafic inclusions. There is a suggestion that mafic rocks near the border of the batholith on Weimer Creek (pl. 1) and in a small area in Greens Gulch (pl. 2) may have a similar origin.

Both the normal quartz monzonite and the mafic variety appear to grade into the porphyritic variety, which is characterized by subhedral phenocrysts of pink potash feldspar, with a maximum of 2 inches but averaging about half an inch in length, and by smaller euhedral phenocrysts of gray plagioclase. The potash feldspar phenocrysts are typically microperthitic, and, near rocks of the mafic variety, small aggregates of ragged biotite and hornblende crystals may be intergrown with them. In this porphyritic variety the ratio of plagioclase to potash feldspar is near 1 to 1 , biotite is more abundant than hornblende, and the total content of mafic mineral is generally less than 15 percent. Conspicuously porphyritic quartz monzonite was not observed within a quarter of a mile of the margin of the batholith.

\section{ALASKITE, APLITE, AND RELATED ROCKS}

Dikes, sheets, and small irregular masses of silicic mafic-poor intrusive rocks are present sporadically in the part of the batholith mapped in the present study and are common in some parts of the batholith outside the area mapped. Rocks of this type have not been found outside the limits of the batholith except in a small area north of Elkhorn (pl. 1).

The largest single body of rock assigned to this category, a crudely dumbell-shaped sill-like mass, crops out near the base of the cirque wall above Icy Lake (pls. 1 and $4 A$ ) and extends northward to the Elkhorn Peak Iron mine (pl. 1, no. 1). This body lies between relatively mafic quartz monzonite of the Boulder batholith and the basal part of the Elkhorn Mountains volcanics. Its upper surface appears to conform approximately to the layering in the volcanic rocks. The nature of its contact with quartz monzonite is uncertain. In some places this boundary appears to be gradational and in other places rather sharp. The mass is exposed for a strike length of about one mile and has a maximum thickness, at the surface, of about 500 feet. Typically the rock is light-colored and fine- to medium-grained 
holocrystalline. It consists of 30 to 35 percent anhedral quartz, 55 to 65 percent anhedral to subhedral potash feldspar (most of which contains spindly perthitic intergrowths of albite or albite-oligoclase), 5 to 10 percent of subhedral albite-oligoclase, less than 1 percent pleochroic brown biotite, and rare small grains of magnetite, zircon and monazite. The chemical analysis of a typical specimen from this intrusive is given in column 50KC-20 of table 2. Graphic and myremekitic intergrowths of quartz and potash feldspar are common. Locally small clusters or vugs partly filled with purple fluorite and faintly smoky quartz were seen; a few contain pyrite.

Other intrusive bodies assigned to this category have about the same mineral and chemical composition (see column $50 \mathrm{KC}-19$ of table 2 ), but range in fabric from aplitic to pegmatitic, although a fine-grained granitic fabric is most common. Locally black tourmaline occurs as rosettes, irregular aggregates, or scattered small clusters that, for the most part, appear to replace preexisting minerals in the alaskite rocks. Within the area mapped, black tourmaline also occurs in and near silicified and brecciated zones in bodies of alaskite and quartz monzonite, locally along joint surfaces in andesitic volcanic rocks, rarely as crystals or crystal clusters in monzonite, and as a gangue mineral in a few metallic mineral deposits.

\section{STOCKS OF GRANODIORITE AND RELATED ROCKS}

The Sagebrush Park stock, the Slim Sam stock, and a few small intrusive bodies consist predominantly of granodiorite. In the Sagebrush Park stock the granodiorite grades to quartz diorite and in the Slim Sam stock to quartz monzonite. The average composition of the Sagebrush Park stock (pl. 2) is 55 to 60 perceni plagioclase, of which many crystals are zoned in the range $A n_{60}$ to $A n_{35}, 10$ to 20 percent orthoclase, 15 to 20 percent quartz, and 10 to 15 percent hornblende and biotite in approximately equal amounts (see table 3 ). the Slim Sam stock (pl. 1) consists of from 40 to 60 percent plagioclase, commonly zoned from $\mathrm{An}_{50}$ to $\mathrm{An}_{3 n}$, from 20 to 35 percent orthoclase, in part microperthitic, 15 to 20 percent quartz, and about 10 percent hornblende and biotite, the former predominating (see table 3). Small amounts of magnetite, apatite, and sphene occur in both stocks; zircon and epidote are rare. A felsic variety of quartz diorite was seen in the central part of the Sagebrush Park stock; no younger alaskitic or aplitic intrusives were seen in either stock.

The Sagebrush Park stock intrudes Mission Canyon limestone which has not been appreciably disturbed structually but has been recrystallized in an aureole that extends outward for several hundred yards from the margin of the stock. Inclusions of limestone are common in the marginal part of the stock.

The Slim Sam stock intrudes upper Paleozoic, Jurassic, and Lower Cretaceous sedimentary rocks. The stock and the enclosing rocks are so poorly exposed that the relations between them could not be determined. Limestone beds in the vicinity of the stock have been recrystallized, and locally small bodies of coarsely crystalline calcsilicate minerals have formed in them. A few of these bodies contain pyrite and sparse copper minerals that have been oxidized to limonite and mala. chite.

A small stock of granodiorite porphyry intrudes Mission Canyon limestone at the junction of Swamp Creek

TABLE 3.-Chemical analyses of rocks from stocks of granodiorite and related rocks and from composite or hybrid plutons

[Rapid-method analyses (Shapiro and Brannock, 1956) by S. M. Berthold and E. A. Nygaard, U. S. Grological Survey]

\begin{tabular}{|c|c|c|c|c|c|c|c|}
\hline & $49 \mathrm{KC}-1$ & $49 \mathrm{KC}-2$ & $49 \mathrm{KC}-3$ & $49 \mathrm{KC}-11$ & $49 \mathrm{KC}-4$ & $49 \mathrm{KC}-5$ & $49 \mathrm{KC}-6$ \\
\hline 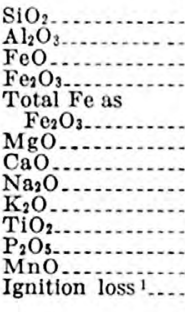 & $\begin{array}{c}60.4 \\
17.8 \\
3.0 \\
3.7 \\
7.0 \\
2.5 \\
6.3 \\
3.0 \\
1.8 \\
.69 \\
.22 \\
.14 \\
1.0 \\
\end{array}$ & $\begin{array}{c}68.0 \\
17.1 \\
1.2 \\
2.1 \\
3.4 \\
.86 \\
4.3 \\
3.7 \\
2.0 \\
.39 \\
.14 \\
.08 \\
.55 \\
\end{array}$ & $\begin{array}{r}56.8 \\
18.6 \\
3.8 \\
4.0 \\
\\
8.2 \\
3.4 \\
7.5 \\
3.3 \\
1.6 \\
.99 \\
.25 \\
.16 \\
.66 \\
\end{array}$ & \begin{tabular}{c|}
60.5 \\
17.2 \\
2.5 \\
3.4 \\
6.2 \\
2.4 \\
5.8 \\
3.4 \\
2.6 \\
.62 \\
.30 \\
.14 \\
1.2 \\
\end{tabular} & $\begin{array}{r}63.8 \\
15.4 \\
2.7 \\
.83 \\
\\
3.8 \\
3.8 \\
4.8 \\
3.2 \\
3.2 \\
.62 \\
.23 \\
.04 \\
2.0 \\
\end{array}$ & $\begin{array}{r}55.8 \\
14.6 \\
6.6 \\
1.9 \\
9.2 \\
7.8 \\
7.4 \\
2.4 \\
2.8 \\
.89 \\
.40 \\
.16 \\
2-.02 \\
\end{array}$ & $\begin{array}{r}53.8 \\
8.4 \\
4.4 \\
2.0 \\
\\
6.8 \\
10.8 \\
15.5 \\
1.3 \\
1.4 \\
.57 \\
.12 \\
.12 \\
1.0 \\
\end{array}$ \\
\hline & 101 & 101 & 101 & 100 & 101 & 101 & 100 \\
\hline
\end{tabular}

1 Includes gain due to oxidation of $\mathrm{FeO}$.

2 Gain due to oxidation of $\mathrm{FeO}$ greater than losses.

49K C-1 Granodiorite; composite sample from Sagebrush Park stock.

2 Felsic quartz diorite from central part of Sagebrush Park stock.

3 Granodiorite from marginal part of Sagebrush Park stock.

11 Granodiorite from Slim Sam stock. Composite of four samples from in. trusive in SE $1 / 4$ sec. 35 , T. 6 N., R. 2 W.

5 Porphyritic mafic monzonite from composite intrusive in SE $1 / 4 \mathrm{sec} .35, \mathrm{~T}$. 6 N., R. 2 W.

6 Mafic orthoclase clinopyroxene gabbro from composite intrusive in SE $1 / 4$ sec. 35 , T. 6 N., R. 2 W.

and the South Fork of Crow Creek (pl. 1). Adjacent to this stock the limestone is bleached and recrystallized, and locally has been replaced by small bodies of calcsilicate minerals that contain sparse pyrite and copper minerals. The stock is formed of homogeneous finegrained granodiorite porphyry that consists of about 30 percent of oligoclase as phenocrysts as much as 2.5 millimeters in length in a granitoid fine-grained ( 0.2 to 0.4 millimeters) intergrowth of quartz (25 percent), orthoclase ( 15 to 20 percent), oligoclase ( 15 to 20 percent), and biotite and hornblende (about 10 percent total). A few phenocrysts of quartz and of orthoclase are present locally (see table 4). Small amounts of magnetite, apatite, and zircon are also present.

The small alluviated basinal area about a mile to the north is underlain in part by an intrusive body of similar appearance and composition. 
TABLE 4.-Quantitative description of rocks from stocks of granodiorite and related rocks

[Plagioclase: items marked with an asterisk $\left(^{*}\right)$ indicate range of anorthite content in zoned crystals. Accessory minerals: a, apatite; ca, calcite; e, epidote; s, sphene; $\mathbf{z}$, zircon]

\begin{tabular}{|c|c|c|}
\hline & $\begin{array}{l}\text { Average } \\
\text { grain } \\
\text { size! } \\
\text { (mm) }\end{array}$ & Location \\
\hline Biotite-hornblende granodiorite..... & 0.5 & Sagebrush Park stock (near north- \\
\hline ...... Do.... & .75 & $\begin{array}{l}\text { east margin) } \\
\text { Sagebrush Park stock (near south- }\end{array}$ \\
\hline Felsic quartz diorite... & .75 & $\begin{array}{l}\text { east margin). } \\
\text { Sagebrush Park stock (central }\end{array}$ \\
\hline Biotite-hornblende granodiorite..... & .6 & $\begin{array}{l}\text { part). } \\
\text { Sagebrush Park stock (central }\end{array}$ \\
\hline Hornblende quartz diorite...... & .6 & $\begin{array}{l}\text { part). } \\
\text { Sagebrush Park stock (near north }\end{array}$ \\
\hline Hornblende quartz monzonite...... & .75 & $\begin{array}{l}\text { margin). } \\
\text { Slim Sam stock .- }\end{array}$ \\
\hline $\begin{array}{l}\text { Hornblende-biotite granodiorite } \\
\text { porphyry }\end{array}$ & .0 & $\begin{array}{l}\text { Stock at junction of Swamp Creek } \\
\text { and South Fork of Crow Creek. }\end{array}$ \\
\hline
\end{tabular}

1 Excluding phenocrysts.

\section{COMPOSITE OR HYBRID INTRUSIVES}

A number of small plutons of diverse or abnormal rock types were mapped as composite or hybrid intrusives. As all of them are poorly exposed, their detailed relations with the enclosing rocks and the relations of the different petrographic types within them could not be determined. All but one of the plutons assigned to this group intrude either Devonian or Carboniferous strata, and all but two contain assemblages of one or more relatively normal light-colored granitoid quartzbearing rocks and one or more dark-colored rocks of diverse texture that are rich in mafic minerals but contain significant quantities of potash feldspar or potashsoda feldspar. One body consists of blotchy porphyritic monzonite, and one, judged from float, consists of a variety of aphanitic igneous rocks and may be a vol-

\begin{tabular}{|c|c|c|c|c|c|c|c|}
\hline \multirow{2}{*}{$\begin{array}{l}\text { Spe- } \\
\text { cific } \\
\text { grav- } \\
\text { ity }\end{array}$} & \multicolumn{7}{|c|}{ Approximate mineral composition in percent } \\
\hline & Plagioclase & $\begin{array}{l}\text { Ortho- } \\
\text { clase }\end{array}$ & Quartz & $\begin{array}{l}\text { Horn- } \\
\text { blende }\end{array}$ & $\begin{array}{c}\text { Biotite } \\
\text { (and } \\
\text { chlorite) }\end{array}$ & Magnetite & $\begin{array}{c}\text { Accessory } \\
\text { minerals }\end{array}$ \\
\hline 2.77 & ${ }^{* 62}\left(\mathrm{An}_{60-33}\right)$ & 12 & 12 & 6 & 5 & 3 & $\mathrm{~s}, \mathrm{z}, \mathrm{a}, \mathrm{e}$ \\
\hline 2. 73 & ${ }^{*} 57(\mathrm{~A}$ n $00-40)$ & 11 & 18 & 6 & 4 & 4 & a \\
\hline 2.65 & $58\left(\mathrm{An}_{40}\right)$ & 8 & 27 & 2 & 5 & $<1$ & $\mathrm{a}$ \\
\hline 2.74 & ${ }^{*} 54$ (Ane0-3s) & 20 & 15 & 6 & 5 & $<1$ & $\mathrm{a}, \mathrm{s}$ \\
\hline 2. 72 & ${ }^{*} 55(\mathrm{An}$ os -10$)$ & 9 & 16 & 13 & 3 & 3 & $\mathrm{~s}, \mathrm{e}$ \\
\hline $\begin{array}{l}2.69 \\
\text { 2. } 68 \\
2.65\end{array}$ & $\begin{array}{l}* 41\left(\mathrm{An}_{50-30}\right) \\
55\left(\mathrm{An}_{40}\right) \\
\cdot 47\left(\mathrm{An}_{30-10}\right)=\end{array}$ & $\begin{array}{l}32 \\
18 \\
17\end{array}$ & $\begin{array}{l}17 \\
14 \\
25\end{array}$ & $\begin{array}{l}7 \\
7 \\
4\end{array}$ & $\begin{array}{l}1 \\
3 \\
7\end{array}$ & $\begin{array}{r}1 \\
2 \\
<1\end{array}$ & $\begin{array}{l}\mathrm{s}, \mathrm{a}, \mathrm{z} \\
\mathrm{a}, \mathrm{ca} \\
\mathrm{a}, \mathrm{z}\end{array}$ \\
\hline
\end{tabular}

230 percent phenocrysts.

canic neck. A quantitative description of the principal rock types in three of the composite or hybrid intrusives is given in table 5. Chemical analyses of three rock types from one of these intrusives are given in table 3.

Although the field relations of these plutons are obscure, their restriction to areas of carbonate rocks and the mineral composition of the rocks that constitute most of them suggest that they may have formed as the result of assimilation of limestone or dolomite by a granodiorite or quartz monzonite magma. For example, about half of the exposed rock in the pluton in the $\mathrm{SE} 1 / 4$ sec. 35, T. 6 N., R. $2 \mathrm{~W}$. (pl. 2) is granodiorite or quartz-monzonite that differs from the rocks of the homogeneous Sagebrush Park stock only in a slightly higher ratio of orthoclase to plagioclase, in the tendency of hornblende to occur as glomerophenocrysts,

TABLE 5.-Quantitive description of rocks in composite or hybrid intrusives

Plagioclase: items marked with an asterisk (*) indicate range of anorthite in zoned crystals.

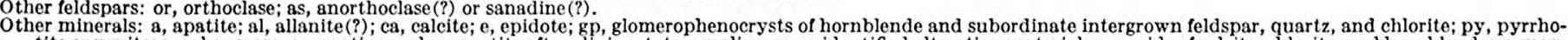

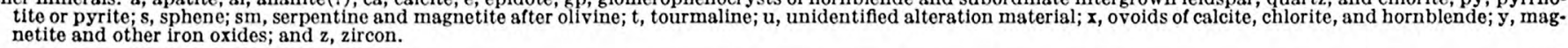

\begin{tabular}{|c|c|c|c|c|c|c|c|c|c|}
\hline & \multirow{2}{*}{$\begin{array}{l}\text { Grain } \\
\text { size }^{1} \\
(\mathrm{~mm})\end{array}$} & \multirow[b]{2}{*}{ Location } & \multirow[b]{2}{*}{$\begin{array}{l}\text { Specific } \\
\text { gravity }\end{array}$} & \multicolumn{6}{|c|}{ Approximate mineral composition in percent } \\
\hline & & & & Plagioclase & $\begin{array}{l}\text { Other } \\
\text { feldspar }\end{array}$ & Quartz & $\begin{array}{l}\text { Hornblende, } \mathrm{h} ; \\
\text { pyroxene, } \mathrm{p} ; \\
\text { olivine, ol }\end{array}$ & $\begin{array}{l}\text { Biotite, b; } \\
\text { chlorite, } \mathrm{c}\end{array}$ & $\begin{array}{l}\text { Other } \\
\text { minerals }\end{array}$ \\
\hline $\begin{array}{l}\text { Hornblende granodiorite with ovoids of } \\
\text { hornblende, chlorite and calcite. }\end{array}$ & $0.5-0.75$ & $\begin{array}{l}\text { SE1/4 sec. } 35 \text {, T. } 6 \text { N., R. } 2 \\
\text { W. }\end{array}$ & 2.62 & $46\left(\mathrm{An}_{35-40}\right)$ & 23 or & 18 & $4 \mathrm{~h}$ & $4 \mathrm{c}$ & $\begin{array}{l}5 \mathrm{x} \text { and } \mathrm{gp} ; \mathrm{a} \\
\mathrm{s}, \mathrm{z}, \mathrm{y}, \mathrm{u}, \mathrm{t}\end{array}$ \\
\hline $\begin{array}{l}\text { Hornblende quartz monzonite with } \\
\text { ovoids of hornblende, chlorite and } \\
\text { calcite, closely similar to rock above. }\end{array}$ & $0.5-0.75$ & ....do do............................. & 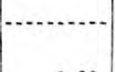 & $* 43\left(\mathrm{An}_{s 3-10}\right)$ & 28 or & 11 & $6 \mathrm{~h}$ & & $\begin{array}{l}9 \mathrm{gp} ; 3 \mathrm{x} ; \mathrm{a}, \mathrm{s}, \\
\mathrm{y} .\end{array}$ \\
\hline $\begin{array}{l}\text { Porphyritic mafle monzonite with abun- } \\
\text { dant phenocrysts as large as } 3 \mathrm{~mm} \text { in } \\
\text { diameter. }\end{array}$ & $0.2-0.5$ & .....do... & 2.90 & *35 (An;0-40) & 29 as & 4 & $7 \mathrm{~h}, 7 \mathrm{p}, 4$ ol & $12 \mathrm{~b}$ & $2 y ; a$ \\
\hline $\begin{array}{l}\text { Augite lamprophyre with } 25 \text { percent } \\
\text { phenocrysts as large as } 3 \mathrm{~mm} \text { in diam- } \\
\text { eter. }\end{array}$ & $<0.1$ & ......do.. & 2.95 & $\left\{\begin{array}{l}40\left(A n_{43}\right) \\
2 \cdot 3\left(A n_{75-10}\right)\end{array}\right.$ & 19 as & 1 & $13 \mathrm{p}, 18 \mathrm{p}^{2}$ & $2 \mathrm{~b}$ & $3 \mathrm{sm}^{2} ; \mathrm{a}, \mathrm{y}$ \\
\hline Mafic orthoclase-clinopyroxene gabbro.. & $\left\{\begin{array}{l}3 \\
1-1.5 \\
1 \\
1-3.5\end{array}\right.$ & \} & 3.00 & $\cdot 13\left(\mathrm{An}_{80-25}\right)$ & 18 or & 5 & $63 \mathrm{p}$ & & $1 \mathrm{py} ; \mathrm{y}, \mathrm{sm}, \mathrm{a}, \mathrm{s}$. \\
\hline Hornblende quartz monzonite............... & $0.5-0.75$ & NW $1 / 4$ sec. 28 , T. 5 N., R. 2 & 2.59 & $24\left(A n_{30-35}\right)$ & 45 or & 25 & $6 \mathrm{~h}$ & & $\mathrm{ca}, \mathrm{e}, \mathrm{s}, \mathrm{y}$ \\
\hline $\begin{array}{l}\text { Porphyritic olivine-augite-anorthoclase } \\
\text { rock with } 60 \text { percent phenocrysts as } \\
\text { large as } 2.5 \mathrm{~mm} \text {. }\end{array}$ & $<0.2$ & ......do... & 2.97 & & 25 as & & $\begin{array}{r}10-15 \mathrm{p}, 56 \mathrm{ol}^{1} \\
\text { and } 4 \mathrm{p}^{2}\end{array}$ & $2 \mathrm{~b}$ & $\operatorname{sm}$ \\
\hline Anorthoclase-augite monzonite........... & 0.5 & $\begin{array}{l}\text { NW1/4 sec. } 22, \text { T. } 5 \text { N., R. } 2 \\
\text { W. }\end{array}$ & 2.66 & $51(\operatorname{An} 70-30)$ & $30 \mathrm{or}$, as & & $19 \mathrm{p}$ & (n.............. & $y, a, a l$ \\
\hline Hornblende granodiorite.. & 0.6 & do & 2. 71 & $47\left(A n_{60-30}\right)$ & 15 or, as & 20 & $15 \mathrm{~h}$ & & 2 py; a, s \\
\hline
\end{tabular}

1 Excluding phenocrysts. 
and in the presence of peculiar "ovoids" of hornblende and chlorite, some having cores of calcite. Conceivably such a rock might result from incomplete reaction between a granodiorite magma and small included pieces of limestone or dolomite. Sinking of large and more abundant blocks of carbonate rock to a deeper portion of such a magma might permit more complete reaction and the formation of differentiates high in calcium and magnesium that, if injected, might consolidate to mafic and calcic monzonitic and gabbroic rocks such as those present. Field relations suggest that the mafic monzonite and pegmatitic rock associated with it are products of assimilation formed at and near the margin of the pluton. Somewhat similar assemblages of rocks in other small plutons assigned to this group suggest that all of them have about the same mode of origin.

Small plutonic masses with similar structural and petrographic features are abundant in parts of Sutherlandshire and north Ross-shire, Scotland (Read, Phemister, and Ross, 1926, p. 148, 155-166; Read, Ross, and Phemister, 1925, p. 45-50; Read, 1931, p. 165-173). Read (1931, p. 165) believes that these rocks are hybrids in the original petrographic sense of this term and attributes their origin to the ". . . admixture of granitic magma with ultrabasic magma or with solid ultrabasic rock." The Scottish hybrid rocks occur in a terrane devoid of limestone or dolomite, whereas the rocks of probable assimilative origin in the southern Elkhorn Mountains occur in a terrane devoid of ultrabasic rocks but rich in limestone and dolomite.

\section{FELSITE DIKES OF UNCERTAIN AGE}

A few pale-buff to light-tan fine-grained felsite dikes cut the Elkhorn Mountains volcanics along the west side of Elkhorn Creek valley (pl. 2). These dikes are subparallel to the Tacoma Gulch fault.

Megascopically, the rocks show a few chalky phenocrysts of feldspar set in a very fine grained groundmass. Under the microscope, the rocks show an irregularly sutured microcrystalline groundmass with less than five percent phenocrysts. Of the phenocrysts, potash feldspar is more abundant than plagioclase. Both types of feldspar are clouded with alteration products. The groundmass is composed of two feldspars, a little quartz, and a few percent of pale, yellow-green micaceous shreds that are probably chlorite.

The age of these dikes is not more definitely known than that they were intruded after deposition of the Elkhorn Mountains volcanics. From their trend, the age is presumed to be later than the Tacoma Gulch fault, perhaps contemporaneous with the batholith, or possibly related to the rhyolitic rocks that occur else- where in the region (Weed, 1912, p. 29 and Knopf, 1913, p. 39-41).

\section{METAMORPHISM}

\section{THERMAL METAMORPHISM}

Most of the igneous bodies in the area have thermally metamorphosed the invaded rocks. This metamorphism ranges from narrow and inconspicous zones of hardened or slightly recrystallized rocks adjacent to small diorite porphyry sills and dikes to relatively broad belts of hornfels and other strongly recrystallized rocks in the vicinity of the Boulder batholith. The effects of thermal metamorphism are most conspicuous in the area around Elkhorn. Plate 5 shows the distribution of thermal metamorphism in this vicinity. In this area near the margin of the batholith, all of the layered rocks have been folded and complexly intruded by several types of igneous rocks. Relatively pure carbonate rocks have recrystallized with a marked increase in grain size, lightening of color, and destruction of sedimentary structures. Argillaceous and siliceous carbonate rocks have been converted to calcsilicate rocks of variable grain size that commonly consist principally of mixtures of diopside and grossularite. Shale has been converted to argillite or hornfels; and sandstone has been changed to vitreous quartzite. Changes in the Elkhorn Mountains volcanics are less conspicuous, but the rocks are recrystallized adjacent to the batholith in a belt ranging in width from less than a hundred feet to a thousand feet or more. Barrell (in Weed, 1901, p. 543-549) described the results of metamorphism of each of the principal rock types but did not describe characteristic features of the different formations in metamorphic aureoles.

The present mapping (pl. 5) in the vicinity of Elkhorn suggests that more of the metamorphism was accomplished by the small stocklike intrusives than Barrell indicated (1901, p. 445). Intense recrystallization is spatially associated with the gabbroic to dioritic Black Butte stock and other stocks, as well as with the batholith. In areas where several intrusions are present, most of the metamorphism seems to have been accomplished by the earliest and more mafic intrusion.

The metamorphic effects described on the following pages, except as specifically noted to the contrary, were observed only in an area of a few square miles around the village of Elkhorn (pl. 5).

\section{PRECAMBRIAN ROCKS}

The Precambrian argillaceous rocks in the Elkhorn district (pl. 5), except within a few hundred feet of the margin of the Boulder batholith, have been only weakly metamorphosed. The least metamorphosed rocks are 
mudstones and siltstones that have been slightly hardened and darkened without loss of sedimentary features such as laminations and ripple marks. Under more severe metamorphism, these rocks are converted to dense dark-gray argillite in which sedimentary features have been largely obliterated. These metamorphosed argillaceous rocks contain a few interbeds of quartzite.

Banded noncalcareous hornfels has been formed in a small area southwest of the Sourdough mine where Precambrian rocks have been intruded by mafic quartz monzonite of the Boulder batholith. The hornfels is dark gray, finely crystalline, and is characterized by indistinct bands of lighter gray material that probably parallel bedding.

\section{PALEOZOIC ROCKS}

The Flathead quartzite is only slightly affected by thermal metamorphism. Typically it retains its characteristic grayish-pink color. Recognizable changes are a general hardening and possibly in some places recrystallization to a quartzite somewhat finer grained than typical Flathead.

The metamorphosed Wolsey shale of the Elkhorn district can be divided into three units, but because of poor exposures the boundaries of these units cannot be sharply delimited. The upper unit, about 50 feet thick, is a very fine grained light-brownish-gray calcsilicate hornfels. Weathered surfaces of this rock are conspicuously ribboned. Some of the ribbons weather in relief, giving the rock a corrugated appearance. The middle unit, about 150 feet thick, consists principally of lightgray locally irregularly blotched or streaked calcsilicate hornfels similar on the fresh surface to the upper unit. The basal unit, about 200 feet thick, is black to darkgreenish-gray, blocky conspicuously laminated argillite or noncalcareous hornfels.

Generally, the three lithologic units of the Meagher limestone can be recognized, even in the innermost part of a metamorphic aureole. The upper and lower mottled units retain some vestiges of the original mottling. The gray limestone typically has been bleached to a lighter shade of gray, and the color of the yellowish silty carbonate rock has been changed to yellowish gray or olive gray. In the most strongly metamorphosed rock the mottles are vague and poorly outlined, brownish or olive tinted, and probably consist of very fine grained calcsilicate minerals. The middle unit has been bleached to a lighter shade of gray than typical, but otherwise is little changed. Part of the Meagher limestone has been recrystallized to a white or yellowish, medium to coarsely crystalline marble in two small areas near Elkhorn, one adjacent to a thin sill on Cemetery Ridge, and the other on the divide between Sourdough and Slaughterhouse Gulches. The marble on Cemetery Ridge was formed from the middle limestone unit of the formation and that near Sourdough Gulch probably was formed from the lower unit of the Meagher.

Most of the Park shale is metamorphosed to a black, very fine grained blocky argillite or noncalcareous hornfels. An upper unit, probably no more than 20 feet thick, forms a distinctive ribboned calcsilicate hornfels in which some ribbons weather in relief. The hornfels probably was formed from a calcareous siltstone or silty limestone similar to the rocks of the upper part of the Wolsey. If so, the Elkhorn district is the only place in the southern Elkhorn Mountains where rocks of such composition are conspicuous in the Park shale.

The two lower units of the Pilgrim dolomite are not exposed in the Elkhorn district. The lower part of the upper unit is dolomite, commonly slightly mottled in shades of light gray. The upper part ranges from a light-gray, dense, very fine grained dolomite marble to moderately coarse grained white dolomite marble. Field tests for dolomite suggest that some dedolomitization has occurred during metamorphism, but conclusive evidence is lacking.

Exposures of the Red Lion and Maywood formations are restricted to the Elkhorn mine and vicinity. The lower half of the unit consists principally of dark-gray to brownish or greenish-gray argillite and calcsilicate hornfels. The upper half consists largely of dolomite and dolomitic limestone that has been moderately recrystallized to form marble.

Most of the beds in the Jefferson dolomite recrystallize to light-gray or white, finely to medium coarsely crystalline dolomite marble and lose their characteristic features, even at a considerable distance from known intrusives, but locally retain their original color in some strongly recrystallized beds. The formation has been most intensely metamorphosed in the area between Cemetery Ridge and Slaughterhouse Gulch and between the tramway road and Slaughterhouse Gulch. At the Klondyke mine near Elkhorn, the dolomite has been metamorphosed to dolomite marble that contains coarse-bladed tremolite and wollastonite.

A three-fold division of the Three Forks shale can be recognized where the formation has been metamorphosed. The lower two-thirds of the formation, a shale unit, alters to black and greenish-black, platy to blocky noncalcareous hornfels that commonly is present as float but rarely crops out. The key fossiliferous limestone bed overlying the shale unit recrystallizes to a white or light-yellowish-gray, finely to medium coarsely crystalline marble that contains faint, irregular streaks of a hard pale-yellowish-green mineral, probably epidote. The upper calcareous siltstone recrystallizes to 
white or light-gray, extremely fine grained, blocky calcsilicate hornfels. The Three Forks shale has been metamorphosed only in the area between Queen Gulch and the head of Slaughterhouse Gulch. Throughout this area the degree of metamorphism seems to be about the same.

Most beds of the Lodgepole limestone are bleached light-gray or white by slight to moderate metamorphism, but some beds remain gray. As a result of more severe metamorphism, the thin-bedded aspect of the formation is emphasized by recrystallization of originally silty partings to calcsilicate hornfels or, more rarely, to coarse-grained garnet rock. Where the metamorphism has been intense the formation is completely bleached and recrystallized to medium coarsely or very coarsely crystalline marble and cannot be separated from the recrystallized Mission Canyon limestone.

The Mission Canyon limestone, where slightly metamorphosed, is incompletely bleached and the contained fossils are only partly recrystallized. In moderately metamorphosed limestone no traces of fossils remain and most beds are bleached and recrystallized to white medium coarsely crystalline marble. The most strongly metamorphosed rocks are white coarsely crystalline marble. The severely contorted, partly recrystallized Mission Canyon limestone on Crow Ridge suggests that plastic flow may have occurred locally in the formation during thermal metamorphism. No evidence could be found of folding or faulting in underlying or overlying rocks in the area of contorted limestone, and similar contortions were not observed at any other locality.

The Amsden formation is not exposed in the Elkhorn district. Float fragments on Crow Ridge suggest that the lower part of the formation alters to greenish-gray, blocky hornfels. The metamorphic products of the upper part of the formation are not known.

The sandstone and quartzite beds of the Quadrant formation in some places have been recrystallized to very fine to medium-grained dense quartzite, but the typical light-gray and light-yellowish-brown colors have been retained. The dolomite and dolomitic limestone beds are commonly concealed, but float fragments indicate that these rocks recrystallized to light-gray or light-greenish-gray, coarsely crystalline marble.

The Phosphoria formation in the Elkhorn district consists almost entirely of recrystallized chert and quartzite. Because of poor exposure and lithologic similarity it is difficult or impossible to separate it from the Quadrant formation. Quartzite beds in the formation are identical to those in the Quadrant, but the chert recrystallizes to light- to medium-gray, very fine grained quartzite that is finer grained than the quartzite beds in the Quadrant.

\section{MESOZOIC ROCKS}

The Swift formation of Jurassic age, the lowermost Mesozoic unit, cannot be distinguished from the Quadrant and Phosphoria formation in the Elkhorn district. Consequently the base of the Jurassic has been mapped at the lowest argillite or noncalcareous hornfels bed of the Morrison formation. Rocks of the Morrison formation are poorly exposed in most of the area. In the vicinity of Icy Lake, the formation consists mainly of light- to dark-greenish-gray, blocky noncalcareous hornfels with some beds of clean quartzitic sandstone in the upper third. On Crow Ridge, it consists of dark-gray noncalcareous hornfels and lightgray, very fine grained to medium-grained quartzite, in part laminated. Some beds of noncalcareous hornfels contain irregular nodules and stringers of calcsilicate hornfels.

Metamorphosed rocks of the Kootenai formation are best exposed on Crow Ridge. The siltstone, mudstone, and shale beds of the Kootenai formation alter to lightto dark-gray, locally purplish, dense, very fine grained argillite or noncalcareous hornfels. Sandstone beds metamorphose to light-colored, fine-grained, in part laminated, clean quartzite or quartzitic sandstone. Pure limestone recrystallizes to white coarsely crystalline marble but the silty carbonate and calcareous tinegrained clastic beds are metamorphosed to light-colored calcsilicate hornfels, some containing irregularly distributed lumps and nodules of calcareous material. The basal "pepper-and-salt" sandstone is metamorphosed to quartzite, and in some places loses its distinctive speckled appearance. The "gastropod limestone", well exposed near Icy Lake, is a white coarsely crystalline marble, but retains indistinct structures suggesting gastropods.

On Crow Ridge dark-gray platy to blocky noncalcareous hornfels and dark-colored, and in part thinly banded, quartzite aggregating about 500 feet in thickness occupy the interval between the Kootenai formation and the Elkhorn Mountains volcanics. These rocks represent the lower black shale unit and part of the sandstone and siliceous mudstone unit of the Colorado formation.

Recrystallization of the Elkhorn Mountains volcanics is conspicuous in places near the batholith and near smaller intrusives of similar composition. The metamorphic aureole adjacent to the batholith ranges from less than 100 feet to at least 1,000 feet in width. The most conspicuous effects and the widest zone observed are west of Elkhorn Peak (pl. 1), where the top of the batholith probably dips beneath the volcanic rocks at a relatively low angle. Megascopically, the changes are an increase in the grain size of the groundmass of the 
volcanic rocks. Microscopically, the groundmass is seen to be a subequigranular hornfelsic or granulose aggregate of plagioclase, orthoclase, quartz, chlorite, biotite, hornblende, pyroxene, and magnetite. Typically some of the metamorphic hornblende forms large irregular crystals that poikilitically enclose small subhedra of plagioclase and subordinate anhedra of orthoclase. Phenocrysts of plagioclase, hornblende, or pyroxene generally are more or less attacked and in intensely metamorphosed rock are completely recrystallized. At the Elkhorn Peak Iron mine, two limestone beds interlayered in recrystallized sedimentary tuff have been thermally altered. The lower impure limestone near the base of the volcanic rocks has been metamorphosed in part to calcsilicate hornfels and in part to marble. The thick pure upper limestone has been recrystallized to white, coarsely to very coarsely crystalline marble except at one locality west of the mine where it is an aggregate of large bladed tremolite crystals and very coarsely crystalline calcite. In a few places these beds have been affected by additive metamorphism.

\section{ADDITIVE METAMORPHISM}

Coarsely crystalline calcsilicate rocks formed by additive metamorphism (high-temperature metasomatism), principally of carbonate rocks, are exposed locally at or near the contacts of several intrusive bodies. Typically these rocks are irregular tabular or podshaped masses adjacent to the intrusive contact, but locally tonguelike bodies extend outward along susceptible beds or along fractures. In the Elkhorn district (pl. 5) such bodies occur locally around the periphery of the Black Butte stock, the Cemetery Ridge stock, and the Boulder batholith. Typically in these bodies two or more of the following minerals occur; garnet (probably mainly andradite and grossularite), diopside, epidote, axinite, calcite, quartz, and locally actinolite, tremolite, wollastonite, and magnetite and hematite. In some cases the assemblage may be wholly due to additive metamorphism; in others it may be entirely due to thermal metamorphism. The most pronounced effects of additive metamorphism are at the Elkhorn Peak iron deposits (pl. 1, no. 1) where an impure limestone bed and volcanic sediments that were probably somewhat calcareous have been altered to aggregates of silicate minerals, magnetite, and hematite. Axinite, actinolite, and tremolite are common locally. Some of the iron ore contains pyrite and sparse chalcopyrite. Smaller bodies that are due, wholly or in part, to additive metamorphism also are exposed on the ridge that trends north from Elkhorn, notably at the Klondyke (pl. 1, no. 5) and Dolcoath (pl. 1, no. 8) mines; northwest of Elkhorn in the vicinity of the Golden Curry mine (pl. 1, no. 11) and the Black Butte stock; southwest of Elkhorn near the Bulwer mine (pl. 1, no. 13), and at the Rothfus iron mine (pl. 2, no. 6). Axinite is common in coarse-grained garnet rocks formed from Cambrian and Devonian rocks north of Elkhorn. Near the Golden Curry mine and the Black Butte stock the Wolsey and Meagher formations have been altered to calcsilicate hornfels irregularly banded with a coarse aggregate of garnet and calcite. Magnetite is abundant at the Golden Curry mine and is common at a few other localities. Where the Turnley Ridge stock cuts the Wolsey and Meagher formations near the Bulwer mine metamorphism has been similar to that in the vicinity of the Black Butte stock, but the zone of metamorphism is narrower. At the Rothfus iron mine, the Wolsey and Meagher formations have been intruded and altered to calcsilicate rocks that locally contain abundantmagnetite and hematite.

\section{STRUCTURE}

The pre-Tertiary sedimentary and volcanic rocks of the southern Elkhorn Mountains have been deformed into a series of northward-trending folds. The large folds are broad and open. Some of the smaller folds are rather tight; one is overturned. Folding commenced at least locally before the Elkhorn Mountains volcanics were extruded, for in two places the volcanics rest unconformably on Jurassic and early Cretaceous rocks. The folded rocks are cut by a few faults of large displacement and many of slight to moderate displacement. Recurrent movement almost certainly took place along some faults. The culmination of folding and faulting followed the accumulation of the volcanic rocks but cannot be dated more precisely than post-Judith River to pre-Oligocene time. A very Late Cretaceous date seems most probable. The Boulder batholith and intrusives related to it crosscut the folded structure. The east margin of the batholith is irregular in detail but straight in places, suggesting that faults may have controlled the emplacement locally. Structures within the batholith are difficult to detect because of the lack of distinctive units that can be used to measure displacement. The batholith most probably was emplaced in latest Cretaceous or early Tertiary time.

\section{FOLDS}

The structure of the folded pre-Tertiary rocks is dominated by the large dome whose center lies near Trail Spring (pl.2). Although not as well defined, two other major folds occur in the area : one, a northward-plunging broad compound syncline adjacent to the north end of the dome; the other, an anticline whose west limb has been engulfed by the batholith (pl. 1, map and sections 
$A-A^{\prime}$ and $D-D^{\prime}$. Smaller folds flank the major folds. These smaller folds tend to be more open in the Mesozoic rocks in the northern part of the area and relatively tight in the Paleozoic rocks in the southern part.

The elongate domal structure is the simplest and most persistent structure in the area mapped. It extends from beyond the southern limits of the map area northward across the Devils Fence quadrangle into the southern part of the Clancy quadrangle. It becomes broad and indistinct in the volcanic rocks at the north end, but is still recognizable to the northern margin of the map area. The long axis of the dome trends slightly east of north. The dome is moderately assymetric with respect to a line passing through Boyd Spring and Trail Spring (pl. 2). The southern part is somewhat broader and plunges more steeply than the northern part. With respect to its long axis, the northern part is roughly symmetrical though complicated by minor folds on its crest and flanks (section $\left.H-H^{\prime}\right)$, and the southern part is slightly assymetric with second-order folds on the west limb more crumpled and generally steeper than those on the east limb (section $L-L^{\prime}$ ). In the central part of the dome, gently to moderately dipping Precambrian rocks are exposed in an area 10 miles long by 4 miles wide. Progressively younger rocks are exposed away from the center in nearly concentric belts. Subsidiary folds paralleling the long axis of the dome are more numerous in the younger beds near the ends than on the flanks of the dome. At the north end these minor folds are relatively open, plunge northward and are confined to the crestal part of the dome, as shown between Jenkins Gulch and South Fork Crow Creek (pl. 1). At the southern end the folds are tighter, more numerous, and locally overturned (pl. 2, map and sec. $L-L^{\prime}$ ).

The broad syncline west of the dome is relatively simple at the north end of the area, but progressively more complex to the south. In the southern half of the Clancy quadrangle the syncline is in the Elkhorn Mountains volcanics. Here it is very broad, trends slightly east of north and plunges gently to the north (pl. 1 , sections $A-A^{\prime}, E-E^{\prime}$ ). Southward it splits into two synclines and an intervening anticline. Farther south it is represented by a series of synclines and anticlines in Paleozoic rocks.

The anticline near Elkhorn is the least well-preserved of the three major folds. After folding, the anticline was cut by the Tacoma Gulch fault (pls. 1 and 2), invaded by stocks of both the older and younger intrusive groups, and its west limb was engulfed by the Boulder batholith. The fold cannot be traced north of the Elkhorn Peak iron deposits (pl. 1, no. 1). South of Elkhorn the fold is invaded by the Turnley Ridge stock of granodiorite porphyry that is believed to have been emplaced along a part of the Tacoma Gulch fault. The crest of the anticline parallels the contact of the batholith, trends east of north, and in at least one place has been invaded by a small mass of quartz monzonite thought to be an outlier of the batholith. Minor folds in the crestal part of the anticline were responsible for the localization of ore in the Elkhorn mine and other nearby deposits.

\section{FAULTS}

Many faults of diverse trend and small to moderate displacement and two faults of northerly trend and large displacement cut the rocks of the southern Elkhorn Mountains. Most of the faults can clearly be assigned to one of several groups: early faults; faults related to the emplacement of older intrusive rocks; faults related to the main episode of folding; faults related to the emplacement of younger intrusive rocks; faults younger than the batholith; and faults of uncertain age and origin. Recurrent motion along some faults is indicated.

\section{EARLY FAULTS}

A few faults may have formed before folding or during the early stages of folding. Perhaps the best example is the northward-trending fault south of Radersburg Pass, at the south margin of the Clancy quadrangle (pl. 1). Here the basal part of the Kootenai formation is faulted against the Quadrant formation, and the apparent stratigraphic displacement is at least 600 feet. Half a mile to the north the fault terminates or the displacement is negligible, for there is no detectable displacement of beds in the Colorado formation or displacement of the unconformity between the Colorado formation and the Elkhorn Mountains volcanics. The fault is definitely younger than the Kootenai formation and may even be younger than the Colorado formation, for faults tend to be dissipated or difficult to trace in the black shale in the lower part of the Colorado formation. It is probably older than the Elkhorn Mountains volcanics, however, because brittle units in the volcanic rocks immediately above the unconformity would almost certainly have been displaced if there had been significant movement along the fault after they had been deposited.

The possibility of another fault older than the Elkhorn Mountains volcanics is suggested in the vicinity of South Fork Lakes (pl. 1). North of the valley filled with glacial debris the unconformity at the base of the Elkhorn Mountains volcanics is underlain by about 600 feet of beds belonging to the Slim Sam formation and the upper black shale unit of the Colorado formation. South of the valley these beds are absent. It is difficult 
to account for the abrupt disappearance of 600 feet of beds beneath the unconformity as a result of erosion or nondeposition unless a fault older than the volcanic rocks is concealed beneath the valley fill. The presence of eastward-trending faults along South Fork of Crow Creek and Jenkins Gulch suggests that such a fault may underlie the valley in the vicinity of South Fork Lakes.

FAULTS RELATED TO THE EMPLACEMENT OF OLDER INTRUSIVE ROCKS

In a few places faults of diverse trend appear to have formed as a result of forcible emplacement of small plutons of diorite porphyry and other rocks related to the Elkhorn Mountains volcanics. At the head of Muddy Lake Creek, a diorite porphyry pluton is bounded on the east by such a fault, and the adjacent Cretaceous sedimentary rocks are locally crumpled and fractured. South of Aldrich Creek about 3 miles east of this pluton ( 2 miles east of the map area) a similar but more striking example of faulting is associated with emplacement of small bodies of gabbro $(\mathrm{H}$. W. Smedes, oral communication). The fault along the base of the sill in sec. 21, T. 6 N., R. 2 W. (pl. 1) may also have been formed by forcible intrusion.

\section{FAULTS RELATED TO THE MAIN EPISODE OF FOLDING}

Most of the faults in the area can be assigned to one of three groups: northward-trending steep faults, northwestward-trending steep faults, and north-northeastward-trending steep faults. These faults are thought to have formed in response to the same forces that produced the folds. The apparent stratigraphic displacement along most of them is 200 feet or less.

Northward-trending faults are prominent in the southeastern part of the Devils Fence quadrangle (pl. 3 ) and are present at the north end of the major dome (pl. 1). They lie along or are parallel to the axial planes of tightly compressed and locally overturned folds (pl. 3, sec. $K-K^{\prime}$ ). They appear to be steeply dipping reverse faults formed by slippage of one limb of a fold over the other during the period of maximum compression from the west. The northward-trending fault along the east margin of the Boulder Valley in this area probably is related to the other northwardtrending faults, though it seems probable that the block west of the fault was dropped by recurrent but normal movement in post-Oligocene time. The fault dips steeply, and to the north it splits and dies out along the axes of two folds. The origin of other northwardtrending faults, though less certain, may be similar.

Steep faults of northwest and east-northeast trend are prominent in brittle rocks of early Paleozoic age on the flank of the major dome (pl. 2) and in Cretaceous rocks at the north end of the dome (pl.1). Most of the faults die out or cannot be recognized in the Precambrian shale and in the Madison limestone. Displacement along the faults may be in either direction. Whether the displacement has been mainly dip slip or mainly strike slip is unknown, but along major faults of similar trend east of the area, the main component of displacement has been strike slip (Freeman, Ruppel, and Klepper, in preparation). The faults of these two sets approximate theoretical shear positions in a block under compression from the west. They probably formed as minor accommodations in brittle beds near the end of the episode of compressional deformation and are probably younger than the northward-trending faults. Many of the ore deposits in the area are replacements in favorable beds along or adjacent to faults of this group.

Faults that parallel or lie at a small angle to the bedding are common in most underground workings. The displacements along them are generally small. In areal mapping, faults of this type are difficult or impossible to recognize unless exposures are unusually good, and consequently few are shown on the areal maps. Nevertheless, movement along faults of this kind has probably contributed to the local thickening and thinning of incompetent beds. Some faults of this kind also may have localized ore deposition.

\section{FAULTS RELATED TO THE EMPLACEMENT OF} YOUNGER INTRUSIVE ROCKS

A few faults appear to have been formed at the time of intrusion of the Boulder batholith and related rocks. The best example is the small horst in competent rocks in secs. 2 and 11, T. 6 N., R. 3 W. (pl. 1), along the strike of an elongate body of quartz monzonite in the incompetent Mission Canyon limestone. The horst probably was formed by forcible injection of a southward continuation of the quartz monzonite body, not yet exposed by erosion. The faults outlining the graben adjacent to the margin of the batholith about half a mile to the south may also have been initiated during emplacement of the batholith. Physiographic evidence suggests that there has been recurrent movement on two of these faults in comparatively recent time.

A block of sedimentary rocks has been uplifted along two faults, one to the north and one to the east of the small exposure of granodiorite porphyry along the South Fork of Crow Creek in sec. 13, T. 6 N., R. 2 W. (pl. 1). Origin of these faults as a result of forcible intrusion is probable.

\section{FAULTS YOUNGER THAN THE BATHOLITH}

The batholith is cut by several steeply dipping faults of easterly and northeasterly trend and by many steeply dipping joints of easterly, northeasterly, northwesterly, 
and northerly trend. So far as can be determined the displacement along these faults is small. Quartz and sulfide minerals have been introduced and the quartz monzonite has been altered along some of these faults. These faults and joints do not seem to be related to the emplacement and cooling of the batholith, for mapping (in progress by the authors and colleagues) indicates that the same sets are common in the batholith and its wall rocks far beyond the limits of the area mapped. Perhaps these faults and joints formed in response to mild regional compression from the west subsequent to the crystallization of much or all of the batholith.

\section{FAULTS OF UNCERTAIN ORIGIN}

$A$ few faults in the area do not clearly belong to any of the groups described above. The two noteworthy examples are the two major faults in the area, the Tacoma Gulch fault and the Horse Gulch fault.

The Tacoma Gulch fault (pl. 1) is a steep fault that trends east of north to the vicinity of the Queen mine and there turns northwestward and is engulfed by the diorite porphyry stock east of the mouth of Turnley Creek (pl. 1). Northwest of the diorite porphyry stock, the fault locally forms the boundary of the Turnley Ridge stock and probably controlled the emplacement of the stock. Farther north the fault is truncated by the Turnley Ridge stock within a few hundred feet of the margin of the batholith. The apparent stratigraphic displacement along the fault increases to the north. At the southernmost exposure of the fault, in secs. 16 and 17, T. 5 N., R. 3 W., Elkhorn Mountains volcanics are on both sides of the fault, and the displacement is probably considerably less than 4,000 feet. Northward, the volcanic rocks on the west side of the fault are in contact with successively older beds on the east side, and at the northernmost exposures, on Turnley Ridge, they are in contact with Precambrian rocks. Here the apparent minimum stratigraphic displacement is 6,000 to 7,500 feet, though part of this apparent displacement may be a result of folding and deep erosion in this area prior to the deposition of the Elkhorn Mountains voleanics.

The trend of the fault in part parallels the contact of the batholith, and, 10 to 15 miles to the north, emplacement of the batholith appears to have been controlled by a fault of similar trend $(\mathrm{H}$. W. Smedes, oral communication).

The block of volcanic rocks west of the fault, although on the stratigraphically downthrown side, is topographically high and has a steep eastward-facing slope, suggesting that movement recurred at the southern end of the 'Tacoma Gulch fault during late Tertiary time but was in the opposite direction and partly cancelled the original displacement along the fault. The present topography.could have formed as a result of differential erosion alone, but the fact that the fault is clearly marked, even in the Tertiary gravels, by a line of springs and trees strongly suggests that there has been movement along the fault in relatively recent time.

Most and perhaps all of the movement along the Tacoma Gulch fault took place after the Elkhorn Mountains volcanics had accumulated and before the Boulder batholith and the diorite porphyry and Turnley Ridge stocks had been emplaced. The greater part of the movement along the fault, and perhaps all of it, took place after the sedimentary rocks east of the fault had been strongly folded. However, the volcanic rocks in the small wedge between the fault and the margin of the batholith seen to be less strongly folded than the sedimentary rocks east of the fault. The difference in degree of folding and the unconformity at the base of the Elkhorn Mountains voleanics in secs. 9 and 10, T. 5 N., R. 3 W., indicate that the sedimentary rocks had been folded before the volcanic rocks accumulated, though the severity and extent of the folding is uncertain. Whether the Tacoma Gulch fault originated during the earliest folding or later is uncertain. Several hypothesis to account for its origin have been considered.

The fault might have formed sometime during the protracted period of recurrent folding as a release in shear in response to compression from the west. 'The part of the fault in the Devils Fence quadrangle approximates one theoretical shear position and that in the southwestern part of the Clancy quadrangle approximates the other. Local intense fracturing in the vicinity of the Elkhorn Queen mine, where the northeastward-trending segment curves sharply into the northwestward-trending segment, tends to support this hypothesis. Another possibility, feasible only if strong folding took place locally in this area before cessation of volcanism-and this has not been proved by other evidence, is that this fault and the similar fault to the north (H. W. Smedes, oral communication) are the borders of areas that collapsed as a result of rapid expulsion of large volumes of material during the period of volcanism. The force of intrusion of a body of magma, not yet exposed, on the east side of the fault might also be considered as responsible for the fault, but the marked convexity of the fault to the east does not give much support to such a hypothesis.

The Horse Gulch fault trends west of north across the north half of the Devils Fence quadrangle (pl. 1, secs. $G-G^{\prime}, H-H^{\prime}$, and $\left.I-I^{\prime}\right)$. The maximum stratigraphic displacement along the fault is thousands of feet. To the south it splits and dies out in the Mission Canyon limestone; to the north it terminates against 
or is displaced by a minor cross fault in sec. $25, \mathrm{~T} .6 \mathrm{~N}$., R. $3 \mathrm{~W}$. North of the cross fault (in secs. 12, 13, 24, and 25, T. 6 N., R. 3 W.) a northward-trending fault of small displacement may be a continuation of the Horse Gulch fault. The displacement along it is much less than the displacement along the Horse Gulch fault south of the cross fault. The dip of the Horse Gulch fault is unknown. Its sinuous trace might indicate a gentle westward dip but more probably it is due to changes in strike of a steeply dipping surface.

The correlation of structures on opposite sides of the Horse Gulch fault is uncertain; several interpretations of relative motion are possible. It is difficult or impossible to account for the displacement by simple dip slip, whatever the attitude of the fault surface. If movement along the fault has been by strike slip, the two anticlines on the east side of the fault probably were originally continuous with the two on the west side, and the maximum lateral displacement has been about 2 miles, the east block having moved relatively northward. Another interpretation is that the fault is a high-angle reverse fault with large components of dipslip and strike-slip movement.

Perhaps the fault is a rotational fault, hinged about where Dry Creek crosses it, and the southern end of the block west of the fault was uplifted while the north end was depressed. If this is correct, the two segments of anticlines that abut the fault in secs. 18 and 19 , T. 5 N., R. 2 W., are parts of the same anticline; the anticline with rocks of Cambrian age at its core east of the mouth of Dry Creek is not distinctly expressed in the Mission Canyon limestone east of the fault; and the anticline with rocks of the Jefferson dolomite at its core in sec. 1, T. 5 N., R. 3 W., east of the fault may be part of the anticline east of Wood Gulch on the west side of the fault. Stratigraphic evidence indicates that the block west of the Horse Gulch fault has been broken by a cross fault concealed beneath Tertiary deposits in Dry Creek. If this is so, rotational movement along the Horse Gulch fault may not have been great for part of the apparent displacement can be accounted for if the block north of the cross fault were dropped.

Another interpretation, perhaps the least likely, is that the fault is an old one, perhaps formed during the early stages of folding, and that the folds on opposite sides of this fault never were continuous but developed independently in response to renewal of compression from the west subsequent to faulting. A weakness of this interpretation is that the trace of the fault makes an angle of $15^{\circ}$ to $20^{\circ}$ with the trace of the axial planes of the folds, and consequently it seems unlikely that the fault would not have been severely deformed if most of the folding of the sedimentary rocks had been accomplished after faulting.

The proximity of the Tacoma Gulch fault and the Horse Gulch fault suggests that they may be related, but no explanation that would satisfactorily account for both faults as products of the same or similar forces has occurred to the authors, unless both were formed by forcible emplacement of igneous bodies not yet exposed by erosion.

Another fault of uncertain origin occupies the valley of Dewey Creek and is inferred on geologic and physiographic evidence to extend across the Tizer Basin to the head of Prickly Pear Creek. The fault has a westnorthwestward trend and vertical or steep dip. Near the mouth of Dewey Creek the stratigraphic displacement is a few hundred feet, the south block having been relatively dropped and perhaps shifted eastward. In the vicinity of Manley Park, the apparent displacement is greater, perhaps a thousand feet or more, south side down, because rocks of the middle member of the Elkhorn Mountains volcanics to the south are in "contact with rocks of the lower member. (pl. 1 , section $A-A^{\prime}$ ). The contact between the batholith and older rocks is covered by glacial debris and direct evidence bearing on the age of the faulting with respect to the emplacement of the batholith could not be found. Physiographic evidence, however, suggests that the fault cuts the batholith and controlled the location of the valley of Prickly Pear Creek, although the greater part of the displacement appears to have been prior to the emplacement of the batholith.

\section{TECTONIC HISTORY}

The tectonic development of the area can be described in terms of three stages, each stage merging into the succeeding one. The oldest stage was a period of relative crustal stability during which sediments accumulated; the intermediate stage, a period of deformation and igneous activity, and the most recent stage, a period of uplift and erosion.

The first stage persisted from late Precambrian to Cretaceous time. The early Precambrian is without record, for rocks of that age are not known in the area. During late Precambrian time several thousand feet of fine-grained dominantly clastic sediments were deposited in shallow water. These rocks were broadly arched and eroded to a surface of negligible relief prior to a marine transgression during the Middle Cambrian. In the Cambrian sea a thin basal sandstone and about 1,700 feet of alternating limestone and shale beds accumulated. The sea apparently withdrew at about the close of the Cambrian period and did not transgress again until Late Devonian time. During this interval 
the area was apparently very near sea level and very stable, for the total relief on the erosion surface formed in pre-Late Devonian time over an area of at least 1,000 square miles was no more than 100 feet and local relief was no more than 10 or 20 feet. If any Ordovician or Silurian deposits accumulated, they were completely removed by erosion before Late Devonian time. The sea that transgressed the area in the Devonian appears to have persisted until Permian time, with one short withdrawal in the latter part of the Mississippian. After the deposition of the Phosphoria formation during the Permian, the sea again withdrew, and once more stabilized conditions that permitted little erosion and no deposition prevailed until late in the Jurassic period, when for a brief interval a sea once again covered the area. During latest Jurassic and Early Cretaceous time the surface of the area was above sea level, and about 1,000 feet of nonmarine sandstone, shale, and limestone of the Morrison and Kootenai formations was deposited. During Colorado time, the area was alternately above and below sea level for nonmarine beds intertongue with marine beds.

This fluctuation of conditions of deposition during Colorado time marks the transition between the long stage of crustal stability that had persisted since the late Precambrian and a stage of extreme instability that characterized the Late Cretaceous. In late Niobrara time volcanism and broad warping, perhaps locally accompanied by stronger folding, commenced. Though the Late Cretaceous history is not completely understood, it appears that volcanism of a dominantly andesitic type continued sporadically but without major interruptions from late Niobrara at least until Judith River time. Many bodies of diorite porphyry and related rock types were intruded during volcanism. Locally, and perhaps over most of the area, slight to moderate folding and faulting took place during the period of volcanism, but the most severe deformation took place after volcanic activity had ceased, for in some places the volcanic rocks are as strongly deformed as the underlying sedimentary rock. At present the main episode of folding cannot be dated more closely than after deposition of volcanic rocks that are at least in part equivalent to the Judith River formation and before the intrusion of the batholith. A Late Cretaceous date seems most probable. Regionally, major thrusting, not represented in the map area, is believed to have occurred at or near the end of the period of folding, and to have preceded the next recorded episode in this area, which is the emplacement of the Boulder batholith and related intrusive rocks. This major intrusive episode cannot be dated more closely than after the folding of the rocks but before early Oligocene; a very Late Cretaceous or Paleocene date is most probable. Gradual uplift of the area commenced in late Niobrara time and probably has continued intermittently to the present time.

The tectonic activity of the second stage merges into the third stage of crustal uplift and erosion. Subsequent to the intrusion of the Boulder batholith and prior to the beginning of the Oligocene period, probably during late Paleocene and Eocene time, the area was carved to a mountainous terrane of mature relief. All the erosional debris must have been washed from the area. During Oligocene time the drainage conditions altered, either because of lava eruption (Atwood, 1916, p. 711) or because of crustal deformation (Pardee, 1950, p. 366) outside the limits of the area of this report. Volcanic ash and fine-grained tuffaceous sediments with some interbedded gravel accumulated in depressions in a maturely dissected mountainous terrane that had about the same configuration as the area has at present. Subsequently, the Oligocene deposits were cut by valleys, that in turn were the site of deposition of Miocene gravel in the Townsend Valley (Pardee, 1925, p. 41). Locally rhyolite was poured out in the valley of Crow Creek (pl. 1), after it had been cut to its present depth. Renewed uplift, probably in part along steep, normal range-front faults, accompanied by minor folding of Oligocene and Miocene beds, was followed by the cutting of pediments across the Elkhorn Mountains volcanics and the Oligocene sediments on the southeast flank of the mountains, and across quartzite and limestone of late Paleozoic age along the lower parts of the valleys of Elkhorn Creek and Dry Creek. These pediments probably correlate with Pardee's (1925, p. 41-42) "bench No. 1 " in the Townsend valley, which is older than the oldest glacial deposits in the area, and therefore probably Pliocene or early Pleistocene. Recurrent movement on range-front faults during Pleistocene or Recent time probably took place along the southwestern flank of the Elkhorn Mountains and along the eastern front of the Elkhorn Mountains, north and east of the map area, where there are low scarps in fan gravel. The Pleistocene and Recent have been times of extensive erosion, except for two or three short intervals when glacial deposits accumulated locally.

\section{GEOMORPHOLOGY}

\section{REGIONAL SETTING}

The Elkhorn Mountains, a part of the main northern Rocky Mountains of western Montana, are bounded to the north, east, and southwest by broad intermontane valleys. To the northwest they merge into the Boulder Mountains. The boundary between the Elkhorn and Boulder Mountains is arbitrarily placed along the val- 
leys of Beavertown Creek and Prickly Pear Creek. Southward the Elkhorn Mountains merge into unnamed hills north of the Jefferson River. The name southern Elkhorn Mountains is used for convenience in this report to cover the areas shown on plates $1-3$, although no topographic features separate this area from the rest of the Elkhorn Mountains to the north.

\section{IITHOLOGIC AND STRUCTURAL CONTROL OF TOPOGRAPHY}

The southern Elkhorn Mountains are divisible into three physiographic units: the low to moderate, grassy to sparsely wooded hills underlain by folded sedimentary rocks of the southern part of the area, the higher and more rugged wooded mountains underlain principally by volcanic rocks in the northeastern part of the area, and the moderately high, moderately timbered area underlain by intrusive rocks in the northwestern part of the area.

The topography of the area is closely controlled by the structure and lithology of the bedrock. In parts of the area underlain by folded sedimentary rocks alternate rows of hills and valleys coincide with alternate layers of more resistant and less resistant rocks. Fractures in these rocks commonly control the formation of gulches, small valleys, and saddles. In areas underlain by volcanic and intrusive rocks, faults and joints are the principal controlling feature in the formation of valleys. Structurally weak zones have been accentuated especially by ice scour and attendant rigorous climate during glaciation.

\section{EVOLUTION OF LAND FORMS}

The southern Elkhorn Mountains appear to have existed as a physiographic feature at least since the early Oligocene, and almost certainly began to take form with the start of volcanism during the Cretaceous. During the accumulation of the andesitic rocks, the area had appreciable relief and was undergoing erosion, and volcanic detritus was washed eastward to the Maudlow area (Billingsley, 1915, p. 35) and probably to the main basin of accumulation of the Livingston formation. The rocks of the area were subsequently strongly folded and invaded by the Boulder batholith and smaller igneous bodies. Presumably, the region must have been moderately elevated and subject to continuous erosion from the Late Cretaceous through the Eocene. In nearby areas Pardee (1925, p. 38), Atwood (1916), and Alden (1954) have all postulated Eocene erosion. Atwood (1916, p. 706) believed that a peneplain was formed, but Alden (1954) and Pardee (1925, p. 38) believed that the uplands were largely reduced to areas of moderate relief, a belief our findings support. Within the map area, it is known that by early

$$
408366-57-5
$$

Oligocene (Chadron) time a mature topography somewhat resembling but probably more subdued than that of the present day had been carved in the Devils Fence quadrangle, and that a red mantle, as much as 30 or 40 feet thick which is interpreted as an oxidized residual soil was locally present. Similar residual mantle of about the same age(?) is reported north of the map area near Canyon Ferry (Parde, 1925, p. 28).

At the beginning of the Oligocene period sediment began to accumulate in the lower parts of the principal valleys. The change from a long period of erosion during which the erosional debris was washed from the area to a period of fluvial and lacustrine sedimentation indicates a blocking of the principal drainage of the area due either to local warping or tilting or to lava flows beyond the limits of the area. Strong downwarping and volcanism accompanied sedimentation at least locally, for example east of Winston, ten miles northeast of the map area, where Oligocene and Miocene sediments, dominantly of volcanic origin, are several thousand feet thick (Pardee, 1925, p. 27). In the area mapped the Tertiary sediments are much thinner, probably nowhere exceeding 500 feet in thickness, but also consist in large part of fine-grained volcanic detritus.

In the southern half of the Clancy quadrangle, no sediments of early Tertiary age are known. This part of the area probably was a highland that was being eroded throughout Eocene, Oligocene, and Miocene time. Airborne ash undoubtedly fell over the entire area from time to time, but was rapidly eroded from the highlands.

Atwood (1916, p. 714), Pardee (1925, p. 4) and Alden (1954) believed that renewed uplift started a new cycle of erosion about the close of Miocene time. In the Townsend Valley east of the map area, the Oligocene and Miocene beds are gently folded and slightly faulted and are truncated by a well-developed pediment surface. Within the map area, near the mouths of Elkhorn Creek and Dry Creek, scattered low outcrops of upper Paleozoic limestone and quartzite also appear to be remnants of an imperfectly formed pediment. These remnants and the well-developed pediment along the eastern flank of the Elkhorn Mountains east of the map area are the product of erosion, possibly initiated by differential warping and in part uplift along northwardtrending fault blocks. The pediment is described by Pardee (1925, p. 40-41) as "bench No. 1." During this period of erosion much of the early Tertiary valley fill was removed. The drainage system established at that time must have been essentially the same as the modern valley system. At about the same time or perhaps a little later, coarse-textured fan gravel and finer-grained gravel deposits that are probably pediment veneers ac- 
cumulated along Elkhorn Creek and Dry Creek. These gravel deposits are composed of materials of local derivation and are as much as 200 feet thick on the west side of Elkhorn Creek. East of the map area similar gravel deposits (the bench gravels of Pardee, 1925, p. 42) are present along Crow Creek valley and between the Limestone Hills and the Elkhorn Mountains. As no fossils have been found in the gravel, their age cannot be precisely determined. Judging from the sequence of events in the area, they are most probably Pliocene in age. Pardee (1925) thinks that similar gravels in the Townsend Valley are early Pleistocene. These fan deposits indicate that the terrain included steep slopes and relatively flat bottomed valleys at some time in the middle to late Tertiary, and that the hills and mountains were in much the same position as they are now.

The pre-Pleistocene topography must have been similar to that of the present day, except that the higher parts of the mountains were less sharply sculptured and the gravel cover of probable late Tertiary age was more extensive. Broad round-topped mountains were present in the southern half of the Clancy quadrangle. Lower gravel-skirted hills flanked them to the south and east. The sites of most of the present valleys were already established, but the lower courses of the principal valleys were more extensively alluviated than they are at the present time.

During the Pleistocene epoch, glaciation sharpened the topographic features, especially in the northern part of the area. Little evidence of glaciation remains in the central and southern part, although as a result of rigorous climate in this periglacial area mechanical weathering of the exposed rocks must have been accelerated, and the increased precipitation that almost certainly accompanied glaciation must have increased the amount of erosion, thus partly exhuming the topography of an earlier stage. In the northern half of the Devils Fence quadrangle, the fan gravels were in part removed from the basin lying between the ridge of fan gravel along the road to Elkhorn and the main ridge of the Elkhorn Mountains.

In the southern half of the Clancy quadrangle, the results of glaciation are conspicuous. Steep-walled cirques are present on all flanks of the central high area and along the divide north of Crow Creek, and broad amphitheaters are present at the head of most streams. Glacial modification of the topography in areas of relatively homogeneous igneous rocks has emphasized structural elements. Joints and faults appear to control the location of the sharp-walled cirques and the cliffs that locally border scoured valleys. Locally minor differences in joint-spacing, texture, or composition control the finer details of the ridgetops and tributary drainage. Smoothed and striated roche moutonée that abound in the glaciated portion of the area provide evidence of glacial scour. Glacial debris masks much of the bedrock, not only in the valleys where there are distinct lateral and terminal moraines, but throughout the drainage of the Tizer Creeks and on most of the higher slopes.

During the last period of valley glaciation, a veneer of coarse bouldery gravel was deposited on rock benches cut along Crow Creek and Eureka Creek within the map area, and along other creeks north and east of the area. These gravel deposits, now preserved as terrace remnants, are thought to have been deposited during the maximum outwash phase of the last glaciation, and presumably correlate with "bench No. 2" of Pardee.

Many small areas of slumped material lie in the steepwalled valleys, but only a few of the larger landslides are shown on the map. One is at the mouth of the South Fork of Crow Creek, just east of the map area. This side is younger than the terrace. Other slides are thought to be of about the same age. Outwash gravel occupies most valleys below the terminal moraines. The deposits are especially conspicuous as fans where streams emerge from the mountains to the flat-bottomed principal valleys. Along Queen Gulch and Elkhorn Creek (pl. 1), the outwash gravel deposits have been mapped separately; elsewhere they have been included with younger alluvial deposits. Most of the terraces are now being mantled by small recent fan deposits from tributary gulches. Alluvium is being deposited along streams, and in ponds and bogs.

\section{METALLIC MINERAL DEPOSITS}

A variety of types of metallic mineral deposits occur within the area mapped. Most are characterized by simple mineralogy and have been valuable for silver, lead, zinc, or gold, or a combination of these metals. Silver has accounted for the greater part of the value of the mineral production. Replacement deposits in carbonate rocks are the most common type, but veins, contact metamorphic deposits, and pipelike bodies of breccia that are cemented by ore and gangue minerals also are present. The greatest number and the greatest variety of deposits are within a 2 -mile radius of Elkhorn (pl. 1). Narrow gold-bearing veins in andesitic volcanic rocks are characteristic of the Tizer Basin. Sporadic small veins and replacement deposits in carbonate rocks are present in the southern part of the map area.

\section{ELKHORN DISTRICT}

\section{GEOLOGY}

The Elkhorn district is coextensive with the belt of complexly intruded sedimentary rocks in the south- 
western part of the Clancy quadrangle (pl. 1). Geologically the district comprises the crestal portion and the east limb of a northward-plunging anticline whose west limb has been engulfed by intrusive quartz monzonite of the Boulder batholith. The sedimentary rocks have been faulted, complexly intruded, moderately to strongly thermally metamorphosed, and locally, metasomatically replaced by solutions rich in boron and iron with the formation of axinite, andraditic garnet, and magnetite. The intrusive rocks of the district form a number of irregular stocks and range in composition from gabbro to granodiorite porphyry. The Boulder batholith, which is thought to be slightly younger than the stocks, borders the district on the west. Prior to the consolidation of the batholith and the formation of the metallic mineral deposits, the Precambrian and Paleozoic sedimentary rocks of the Elkhorn district were faulted against Upper Cretaceous volcanic rocks along the arcuate Tacoma Gulch fault. This fault possibly fostered the deposition of metallic minerals in the Elkhorn district by providing a major channelway for mineralizing solutions whose origin was relatively deep and also by moving carbonate rocks into an environment where mineralizing solutions were available and where temperature and pressure conditions permitted replacement of carbonate rock by these solutions.

\section{TYPES OF DEPOSITS}

\section{REPLACEMENT DEPOSITS IN CARBONATE ROCKS}

The ore bodies of the Elkhorn mine and a number of smaller deposits in the Elkhorn district are replacements of Paleozoic carbonate rocks. Argentiferous galena, associated with at least a small amount of pyrite and sphalerite, appears to be common to all. Chalcopyrite, tetrahedrite, bournonite, argentite, and quartz gangue are present in a few. Most of the ores contain both silver and gold, but the ratios of these two metals are markedly different in different deposits. The nearsurface parts of the known deposits have been more or less oxidized with the formation of cerussite, calamine, smithsonite, iron oxide, and green and blue secondary copper minerals. Native silver and native gold have been recognized only in the oxidized parts of ore bodies, some unusually rich. No secondary sulfide enrichment has been recognized in the district.

The most important ore bodies of the replacement type are those in the Elkhorn mine. They appear to have been closely controlled by both structural and stratigraphic features. Two general types of ore have been recognized in the Elkhorn mine (Weed, 1901, p. $477-492)$ : siliceous ore that forms an almost continuous tabular replacement body in the uppermost bed or beds of the Pilgrim dolomite, and nonsiliceous ore that forms pods and irregular-shaped bodies at lower horizons in the Pilgrim. Important quantities of siliceous ore are limited to minor anticlinal crests beneath a hanging wall of silicified shale or argillite of the Red Lion formation. Locally, brecciated and silicified shale within or immediately above the ore horizon indicates that there was premineralization movement along the contact of the Pilgrim dolomite and Red Lion formations, probably during folding. The nonsiliceous footwall bodies also appear to be localized in certain beds or groups of beds and to be related to the same folds that localized the hanging-wall ore, but their relation to structural and stratigraphic features has not been determined in detail, for they are in recrystallized dolomite in which bedding is generally indistinct or undetectable.

Lead-gold ore in the Keene mine is also localized in the crestal part of a minor anticlinal flexure in the upper part of the Pilgrim dolomite. Lead-gold ore in the $\mathrm{C} \& \mathrm{D}$ mine is localized along one or more beds in the Mission Canyon limestone near an intrusive tongue of quartz monzonite. The ore body that was mined is on the east flank of the major anticline and may coincide with a subsidiary anticlinal nose, although the detailed structure in the vicinity of the deposit could not be determined owing to recrystallization of the limestone and inaccessibility of most of the mine workings. At the Union mine silver-lead replacement deposits were explored in the lower part of the Lodgepole limestone near the crest of the major anticline, but, as the underground workings were inaccessible, no details of the structural relations of the deposit could be obtained.

On the Swissmont and Pittsmont claims gold ore was mined from the upper part of the Meagher limestone. Examination of the walls of an elongate open pit from which the near-surface part of the main ore body was mined suggests that the ore body was tabular, steeply dipping, and probably deposited along a fracture zone that transects bedding. The Park shale may have served as an impervious capping beneath which the ore was localized. The limestone in the walls of the pit is not noticeably metamorphosed, but it is cut by conspicuous limonite-filled joints and fractures and may constitute low-grade ore.

Other lead-silver or gold replacement bodies in carbonate rocks have been prospected. Some were too small or low grade to be of interest; others were not sufficiently explored to determine their worth. Details of the geology of most of these prospects are unknown, because of inaccessible mine workings and the lack of outcrops. 


\section{CONTACT METAMORPHIC DEPOSITS}

Small replacement bodies of high-temperature silicate minerals that contain magnetite, specularite, pyrite or chalcopyrite, or combinations of these minerals, are common in carbonate rocks near the margins of intrusive bodies in the Elkhorn district. Two deposits of this type have been exploited for iron as a smelter flux, and from one a significant amount of gold was recovered. Both deposits are in rocks at or near the margin of the Boulder batholith. On the south and west slopes of Elkhorn Peak magnetite intergrown with andradite, epidote, calcite, quartz, actinolite, axinite, pyrite, specular hematite, and rare chalcopyrite replaces impure thermally metamorphosed calcareous sediments and probably also andesitic volcanic rocks. Knopf $(1913$, p. 134$)$ reports that magnetite is also present as "thin strings and quartz-magnetite veinlets traversing the garnet rock." The iron ore that was mined is reported to have contained a few hundredths of an ounce of gold per ton. The ore bodies are believed to be irregularly lenticular, but abundant soft iron oxides, probably formed principally by oxidation of andradite, obscure the detailed geologic relations in the mine area. All underground workings are inaccessible and surface pits are badly caved. The Golden Curry mine exploited gold- and copper-bearing iron ore deposits in and adjacent to a narrow tongue of quartz monzonite from the Boulder batholith that cuts calcareous beds of Wolsey shale. Knopf (1913, p. 137) briefly described four types of deposits in the mine; two appear to be of contact-metamorphic origin. Owing to sloughed and inaccessible workings and lack of exposures in the mine area, no additional information on the deposits could be obtained in the present study. At the Rothfus iron mine, in the SE $1 / 4$ sec. 19, T. 5 N., R. 1 W. (pl. 3), magnetite, hematite, and high-temperature silicate minerals replace Meagher limestone adjacent to a small irregularly shaped intrusion of diorite porphyry.

The Dolcoath (Knopf, 1913, p. 133-134) and Klondyke deposits are interesting in that they contain a goldbearing telluride mineral in an assemblage of hightemperature silicate minerals. The Dolcoath ore body comprises intergrown garnet, diopside, calcite, and epidote, with small amounts of bismuthinite, tetradymite and chalcopyrite that has replaced a thin stratum of impure limestone in the Park shale. At the Klondyke mine irregular masses of silicated dolomite, localized partly along favorable beds and partly along sheared zones, contain scattered blebs of pyrite, chalcopyrite and an unidentified gold-bearing telluride (Wade V. Lewis, oral communication). Native gold in both of these deposits is probably a product of oxidation of auriferous telluride. The Golden Moss and the Car-
mody-Papesh deposits may also be characterized by the association of gold with high-temperature silicate minerals. On the Bulwer and adjacent claims sporadic occurrences of secondary copper minerals have been prospected in thermally metamorphosed Cambrian and Devonian carbonate rocks along the margin of a granodiorite porphyry intrusive.

\section{PIPELIKE BRECCIA DEPOSITS}

Two pipelike bodies of brecciated rock cemented by quartz, tourmaline, and sulfide minerals are known in the district; both contain appreciable amounts of gold and silver as well as lead and zinc. A virtually unexplored body of quartz, tourmaline, and pyrite in the Tizer Basin may be of the same general type. At the Elkhorn Queen mine along the south fork of Queen Gulch (pl.2) a steeply plunging pipelike ore body cuts across granodiorite porphyry and folded and faulted thermally metamorphosed shale of the Three Forks shale. Ore consists of more or less brecciated porphyry or hornfels that has been replaced or cemented by quartz, black tourmaline, galena, pyrite, sphalerite, and sparse arsenopyrite. The rocks in the mine area are cut by many faults of probable small postmineralization displacement. Some faults may have been important in localizing the pipe. The upper part of the ore body has been rather thoroughly oxidized and has yielded a substantial quantity of relatively high grade gold-lead-silver ore. At the Skyline mine several hundred yards north of Leslie Lake (pl. 1, no. 6) a pipelike brecciated zone in gently dipping andesitic fragmental rocks has been cemented by a similar mineral assemblage. The deposit is in a glaciated valley near the crest of the Elkhorn Mountains and has been affected only slightly by oxidation.

\section{PRODUCTION}

The Elkhorn district is known principally for the Elkhorn (Holter) mine, which has been one of the larger producers of silver-lead ore in Montana. Available information on production from the district is summarized in the following table.

Metals produced in the Elkhorn district

\begin{tabular}{|c|c|c|c|c|c|}
\hline & $\begin{array}{c}\text { Gold } \\
\text { (ounces) }\end{array}$ & $\begin{array}{c}\text { Silver } \\
\text { (ounces) }\end{array}$ & $\begin{array}{c}\text { Lead } \\
\text { (tons) }\end{array}$ & $\begin{array}{c}\text { Zinc } \\
\text { (tons) }\end{array}$ & $\begin{array}{c}\text { Copper } \\
\text { (tons) }\end{array}$ \\
\hline $\begin{array}{l}\text { Elkhorn mine, prior to } 19011 \ldots \\
\text { Elkhorn mine, } 1901-19532 \\
\text { All other mines, } 1901-1948\end{array}$ & $\begin{array}{r}8,513 \\
11,502 \\
50,000\end{array}$ & $\begin{array}{r}8,922,362 \\
5,860,389 \\
200,000\end{array}$ & $\begin{array}{l}2,000 \\
5,054 \\
1,250\end{array}$ & $\begin{array}{r}2,881 \\
200\end{array}$ & $\begin{array}{r}83 \\
300\end{array}$ \\
\hline
\end{tabular}

1 Data from Weed (1901), pp. 414-415.

2 Data from U. S. Bureau of Mines, Economies and Statistics Branch; published with permission; approximately one-fourth of the gold, one-fifth of the silver, onefourth of the lead, and all of the zinc was recovered from tailings and dumps.

3 Approximate; data principally from U. S. Bureau of Mines, Economics and Statistics Branch; published with permission. Production prior to 1901 unknown.
The bulk of the recorded production of gold was from the Golden Curry mine and The bulk of the recorded production of gold was from the Golden Curry mine and Queen and C \& D mines, and most of the copper from the Golden Curry mine. 
TIZER BASIN AREA

Around the margin of the Tizer Basin, at the head of Crow Creek, a number of gold-bearing veins and placer deposits have been exploited. The central part of the basin is almost entirely covered by glacial deposits. Andesitic fragmental rocks and flows that are cut by intrusive rocks similar in composition and related in origin to the extrusive rocks crop out around and presumably underlie the covered area. The margin of the Boulder batholith is 2 to 3 miles west of the known bedrock deposits of the area.

The veins are narrow and mineralogically simple, consisting in the oxidized zone principally of soft limonitic material with some vuggy quartz and gold, and beneath the oxidized zone of vuggy quartz, sparse pyrite, galena, sphalerite, chalcopyrite, and rare specks of gold and tetrahedrite(?) in sheared and altered andesite. Ore shoots are small, but some are high grade. Production has come almost entirely from the oxidized portions of veins. Limited exploration in the Callahan and Center Reef veins indicates that the grade of primary ore is distinctly lower than that of oxidized ore.

Production from the area has probably been of the order of 9,000 ounces of gold, 20,000 ounces of silver, and 100 tons of lead.

\section{OTHER AREAS}

\section{SOUTH HALF OF CLANCY QUADRANGLE}

The southwestern part of the Clancy quadrangle is underlain by quartz monzonite or granodiorite of the Boulder batholith. Over much of this area the rocks are very poorly exposed. Scattered occurrences of limonite-stained granitic rocks and narrow veins with sparse sulfide minerals have been superficially prospected, but none is likely to yield any significant quantity of ore. The Golconda district, from which some gold-silver-lead ore has been mined, is less than a mile west of the northern part of the quadrangle.

Deposits of metallic minerals in the southeastern part of the quadrangle, except for the Tizer Basin area, are scattered and of relatively small size. Oxidized replacement deposits that contain limonite and sparse secondary copper minerals in thermally metamorphosed upper Paleozoic carbonate rocks have been prospected along the west side of the Slim Sam stock, on the north side of the small stock at the confluence of Swamp Creek and the South Fork of Crow Creek, and south and east of the stock in the NE $1 / 4$ sec. 12, T. 6 N., R. $2 \mathrm{~W}$. Some of these deposits contain garnet and other high-temperature silicate minerals.

A number of narrow gold veins and silver-lead veins cut andesitic rocks east of the Tizer Basin area in the northeastern part of the quadrangle. Most of these veins are oxidized and consist of soft limonitic material with some admixed vuggy quartz and pyrite; some contain gold; some contain cerussite and, rarely, galena; and some contain all of these minerals. Silverlead veins with a gangue of quartz and calcite occur at one locality (Bonanza). These veins are in the upper part of the Mission Canyon limestone along the crest of the major domal structure.

\section{NORTH HALF OF DEVILS FENCE QUADRANGLE}

A number of scattered deposits of several geologic types are known in the north half of Devils Fence quadrangle. Most of them are small. The Elkhorn Queen deposit, included in the Elkhorn district, is at the north margin of the quadrangle. At the Tacoma mine, a mile to the south, narrow quartz veins in andesite have been explored. The veins contain cerussite and sparse galena and are reported to be valuable chiefly for silver and gold (Stone, 1911, p. 97).

Sporadic limonitized replacement bodies as much as 75 feet long and 15 feet thick in the key limestone of the Three Forks shale along the belt of outcrop that follows the line between R. $2 \mathrm{~W}$. and R. $3 \mathrm{~W}$. are reported to contain some gold. They may be the product of thorough oxidation of high-temperature metasomatic replacement deposits that consisted of iron-rich garnet, pyrite, hematite, and possibly some magnetite.

Small bodies of contact silicate minerals with some limonite and very sparse secondary copper minerals occur locally in the Mission Canyon limestone around the south margin of the Sagebrush Park stock and in inclusions of marbleized limestone in the stock. One small pipelike replacement body of silver-lead ore (Passover claim) is localized along the intersection of a minor fracture and a favorable dolomite bed in the Quadrant formation. Most of the carbonate rock formations of the area contain sporadic small replacement pods of jasper. A few are reported to contain some silver and gold, but none have been mined.

At the Spar mine silver ore with a barite gangue has replaced a favorable bed in the Jefferson dolomite. The ore body is at the crest of the major domal structure. It is overlain and underlain by thin strata of shale and appears to be limited on two sides by steeply dipping joints. Both features are thought to have been important in localizing the ore body.

Other deposits that have been explored and have produced some ore are the Rothfus, a metasomatic replacement of Meagher limestone by magnetite and hematite with intergrown high-temperature silicate minerals at and near the contact of a dioritic intrusive; the Parker group of small manganiferous lead-silver bearing re- 
placement bodies in the Meagher limestone; and the Katiedid, a copper-bearing quartz vein in the Greyson shale.

\section{SOUTHEAST PART OF DEVILS FENCE QUADRANGLE}

Metallic mineral deposits have been explored at only two localities in the southeast part of the Devils Fence quadrangle. Only one, the Ida mine, has yielded a significant quantity of ore. At the Ida mine, silver-lead ore that contains some zinc has been mined from two veins, one along the contact between a diorite sill and Greyson shale and the other within the diorite. Both veins are narrow and consist of strands of fault clay with lenses of quartz and silicified rock that contain galena, sphalerite, and pyrite or limonite. The ore was partly oxidized above the present-day water table. On the $J$ and F No. 1 claim a zone of silicified Greyson shale at or near the margin of a diorite sill was explored. The dumps contain a little galena.

\section{SUGGESTIONS FOR PROSPECTING}

The south central part of the Clancy quadrangle is considered to be the part of the area mapped that is most likely to contain important undiscovered metallic ore deposits. The Elkhorn mining district is the only place along the east margin of the batholith where Paleozoic carbonate rocks, which are favorable hosts for replacement ore deposits, crop out in contact with or close to the Boulder batholith. Elsewhere along its east margin the batholith is in contact with Late Cretaceous volcanic rocks that overlie the Paleozoic and Mesozoic sedimentary rocks, and horizons that might contain replacement deposits are from several hundred to a few thousand feet beneath the surface. The writers believe that if any districts similar to the Elkhorn district occur at depth elsewhere along the intrusive ontact, their presence may be indicated by an unusual amount of fracturing in the overlying volcanic rocks, and by leakage of abnormal amounts of heavy metals into these fractured rocks. If this reasoning is correct, careful search for abnormally fractured zones in the volcanic rocks near the batholith, supplemented by sampling of rock and soil for determination of heavymetal content might indicate areas for further testing by physical exploration.

In the Elkhorn district proper the surface has been thoroughly covered by conventional methods of prospecting but no comprehensive effort has been made to discover blind ore bodies or bodies that may be concealed by thick overburden. Here also more detailed mapping might reveal minor anticlinal flexures or mineralized faults that may have been important in localizing replacement deposits in carbonate rocks, and rock and soil sampling might point out anomalies that would warrant testing by more costly physical methods of exploration. In applying such techniques particular attention might be directed toward areas that are believed to be underlain by the upper part of the Pilgrim dolomite.

The volcanic rocks around the margin of the Tizer Basin are cut by a number of gold-bearing veins that are narrow, though locally high grade. None of them have been large producers of ore. Undiscovered veins of about the same potential may lie beneath the glacial cover in the south central-part of the Clancy quadrangle, but it is doubtful whether geochemical or any other feasible means of prospecting would lead to the discovery of relatively small targets beneath a thick cover of transported material of relatively recent origin.

In addition to the above-stated generalizations concerning the search for undiscovered ore deposits, several specific possibilities for exploration around known ore bodies seem worthy of mention. An interesting possibility exists in the area of the Spar mine (fig. 5). It is conceivable that the Spar deposit represents the leakage along known steep fractures of solutions that deposited the greater part of their metallic load at somewhat greater depth. The favorable contact between the Pilgrim dolomite and the Red Lion formation lies not more than 400 feet beneath the Spar ore horizon and could be probed by diamond-drill holes at a moderate cost. It is also possible that new ore bodies or extensions of known ore bodies might be found by additional exploration both laterally and in depth along the contact of the Pilgrim and Red Lion formations in the Elkhorn and Keene mines (pl. 6). Also, the upper half of the Pilgrim dolomite in these two mines has not been exhaustively explored. Careful mapping of the stratigraphic and structural relations of the ore bodies that have been mined might provide the information necessary to formulate a scund exploration program. Deeper exploration and additional lateral exploration in the Elkhorn Queen mine (pl. 2) is also judged to be worthwhile. It would be particularly interesting to test the intersection of the ore pipe, or faults associated with it, and the contact of the Three Forks and Jefferson formations, which might be a favorable horizon for the occurrence of replacement ore bodies.

\section{NONMETALLIC MINERAL DEPOSITS}

Several useful nonmetallic minerals and rocks occur in the area mapped, but none of the known deposits appear to warrant exploitation under present conditions, either because of the quality or the quantity of material available or the location of the deposits. It is unlikely that deposits of these materials will be found 
that are much better suited for exploitation than those already known.

Barite.-Barite is the principal gangue mineral of the silver ore at the Spar mine (fig. 5). The quantity available, however, is very small and concentration would be required to get a product suitable for marketing. The silver ore that is mined is shipped to a smelter without concentration.

Bentonite.-Beds of bentonite are known in the lacustrine Tertiary deposits east and northeast of the area mapped but none have been found within the area mapped, although some beds of bentonitic clay and silt are known.

Phosphate rock.-Beds of very low grade phosphatic sandstone or quartzite and chert are present in the Phosphoria formation throughout the area mapped, but phosphate rock in thicknesses greater than one foot is known at only two localities within the area: in SE1/4 sec. 7 T. 3 N., R., 1 W. and in the $\mathrm{E} 1 / 2$ of sec. 10, T. 5 N., R. $3 \mathrm{~W}$. The best combination of grade and thickness is in sec. 7, T. 3 N., R. $1 \mathrm{~W}$ where 4.1 feet of phosphate rock, including a thin medial septum of phosphatic shale, average 23.6 percent $\mathrm{P}_{2} \mathrm{O}_{5}$. In sec. $10, T .5 \mathrm{~N}$., R. $3 \mathrm{~W}$., the thickness of phosphate rock of about the same quality probably does not exceed 2 feet.

Limestone and dolomite.-Thick units of rather pure limestone and of high-quality dolomite are present in the Mission Canyon limestone and in the upper part of the Pilgrim dolomite, respectively. Both of these formations crop out in situations suitable for open-pit mining, but local demand for these products has not been sufficient to justify their exploitation.

Quartzite.-The Flathead quartzite has been mined from a quarry in the Limestone Hills several miles east of the area mapped and used as an ingredient in cement manufacture at Trident, Mont. This same formation crops out at a number of localities in the area mapped, but all are at a greater distance from a potential market than the Limestone Hills deposit, and consequently none have been exploited.

\section{DESCRIPTIONS OF MINES AND PROSPECTS}

\section{ELKHORN DISTRICT}

\section{ELKHORN MINE}

The Elkhorn (Holter) deposit has yielded most of the ore produced from the district. The deposit and the mine (pl. 1, no. 7) were described in detail by Weed (1901, p. 470-504) at the close of the period of greatest productivity, when economically minable ore was considered to be exhausted. As the mine was closed and most of the workings were inaccessible at the time of the present study, much of the following brief description of the deposit has been condensed from Weed's report and from a shorter, but more recent, report by Knopf $(1913$, p. 135,136$)$. Plate 6 is a compilation of information from these two reports together with information obtained in the present investigation.

The mine was reopened in 1902 and operated continuously from 1906 to 1912; during this time 257,752 tons of ore were mined from which 7,870 ounces of gold, 4,749,541 ounces of silver, 3,463 tons of lead, and 23 tons of copper were recovered. ${ }^{\circ}$ Mine production since 1912 has been slight, but a significant recovery of metal has been made from treatment of tailings and dump rock.

Prior to 1902 most of the ore was mined from two interconnected ore shoots along the contact between the Pilgrim dolomite and the overlying Red Lion formation (Weed, 1901, pl. 57). These ore shoots, which are referred to as hanging-wall bodies by Weed, were deposited along two northeastward-plunging, minor anticlinal crests on the east flank of a major anticline. The minor anticlines merge near the surface and diverge down the plunge so that the ore deposit had the form of an inverted $\mathbf{V}$ both in plan and in longitudinal section. The shoots decreased in precious metal content and increased in zinc content in depth, and both are reported to have virtually tapered out or become noncommercial at or above the 1,850-foot level, although some ore was mined down to the 2,300-foot level.

Ore from these shoots is described (Weed, 1901, p. 483 ) as consisting of nearly solid quartz containing small amounts of argentiferous tetrahedrite, galena, pyrite, sphalerite, bournonite, and, probably, one or more unidentified silver minerals. Ore of this type was chloridized and amalgamated in a mill at the mine.

Prior to 1902 some ore also was mined from irregular replacement bodies in the footwall of the main Pilgrim and Red Lion ore horizon (Weed, 1901, pl. 57). These Weed called footwall bodies or lead chambers and noted (1901, p. 471) that they were "isolated bodies connected by fissues or rusty stringers with quartz [hanging-wall] ore shoots, but of irregular shape and position, and often of large size." From 1902 to 1912, other deposits of this type were discovered and mined as far as 80 feet stratigraphically belo. the top of the Pilgrim. In recent years small ore bocies have been found more than 150 feet below the top or the Pilgrim dolomite in the Sophia workings in the footwall of the Elkhorn mine proper. In the upper levels of the Elkhorn mine a number of chambers are accessible from which footwall ore bodies were mined. Some bodies are roughly accordant to bedding and appear to have been localized beneath a

Data from U. S. Bureau of Mines, Economics and Statistics Branch. Published with permission. 
thin shale bed about 20 feet beneath the top of the Pilgrim dolomite. Knopf (1913, p. 135) reports that two inconspicuous bedding surfaces in dolomite, one 40 feet and one 80 feet below the top of the Pilgrim, have also localized some ore bodies. Others are irregular branching and pipelike bodies that cut across bedding and are not controlled by any obvious stratigraphic or structural feature. In the Sophia workings some concentrations of metallic minerals seem to be related to inconspicuous fractures. The footwall ore bodies consist mainly of argentiferous galena, sphalerite, and pyrite with sporadic tetrahedrite in a gangue of partly recrystallized dolomite wall rock and a little quartz. Ore from the footwall bodies was not milled but was shipped directly to a smelter. Low-grade ore from these bodies was either left in the mine or discarded on the mine dumps, which have in subsequent years been reworked.

The upper part of the Elkhorn ore bodies was rather thoroughly oxidized, and slight oxidation persisted to the bottom of the mine. Some of the thoroughly oxidized near-surface ore was unusually rich and some yielded exceptionally fine specimens, particularly of native silver and calamine (Weed, 1901, p. 459). No secondary sulfide enrichment has been recognized.

The Elkhorn mine and vicinity has not been exhaustively explored. In the Elkhorn mine proper (including the Sophia workings) few drifts probe the favorable contact of the Pilgrim and Red Lion for more than a few tens of feet beyond the outer margins of the two hanging-wall ore bodies and only three or four short crosscuts have been driven into the hangingwall rocks. Probably little systematic exploration was done for footwall ore bodies in the lower part of the mine where the ore is reported to contain more zinc than lead. Except for a few shallow pits, the only other exploration in this vicinity along the Pilgrim and Red Lion contact or in the upper part of the Pilgrim has been at the Keene mine where another minor anticlinal flexure has been explored to a depth of about 150 feet.

As shown in plate 6 the Elkhorn hanging-wall ore bodies were localized by two anticlinal flexures that merge near the surface and diverge in depth. The anticlines are minor features and the dimensions of the ore body along each of them was likewise rather small, if considered as a blind target for exploration. Both of these bodies extended down the plunge for approximately 2,000 feet. Both were commonly from 10 to 25 feet and in places as much as 40 or 50 feet thick. The south ore body had a maximum breadth of 200 feet, and the north ore body, 100 feet. In the upper part of the mine, where the anticlines merged, the two ore bodies were not clearly separable and the total breadth of ore was about 500 feet. In the bottom part of the mine the two ore bodies were about 900 feet apart. The thickness, breadth, and silver content of both ore bodies decreased irregularly but persistently with depth.

Similar minor structures that may have localized ore may be present elsewhere along the belt of Pilgrim and Red Lion rocks that is cut off to the north by the Black Butte stock and that is probably cut off down dip to the east by the Cemetery Ridge stock. Such minor structures probably could not be recognized at the surface, for exposures are very poor, but systematic sampling of soil and rock in this area for determination of heavy-metal content might be employed in an attempt to discover concealed or blind occurrences of ore. This technique was employed by Huff and Klepper in a small area north of the Elkhorn mine (pl. 6). In that area the Pilgrim and Red Lion contact is exposed only in an abandoned railroad cut and at the Keene shaft. Elsewhere it has been mapped on the basis of distribution of float. In each of six profiles the contact coincides with abnormal concentrations of heavy metals in soil samples. This sampling also indicated a zone relatively rich in metals in soil overlying the Red Lion formation about 100 feet east of (and 50 feet stratigraphically above) the Pilgrim and Red Lion contact, and sporadic anomalies in the Pilgrim. The fact that samples of rock collected from the railroad cut showed no unusual metal content even though the overlying soil contained as much as 1 percent heavy metals suggests that some contamination of the soil may have occurred as a result of previous mining and milling activities. Nevertheless, the general pattern appears to be significant and suggests that sampling elsewhere along the strike of this group of beds might be worthwhile.

\section{KEENE MINE}

About 650 feet north of the Elkhorn shaft the upper part of the Pilgrim dolomite has been explored by a shaft and connecting crosscut adit and appended overhead and underhand stopes (pl. 6). High-grade goldlead ore is said to have been mined, but the size of the stopes suggests that the production did not exceed 500 tons of ore. The principal ore body in the Keene mine (pls. 1, no. 6) appears to have been localized on an anticlinal crest beneath a thin shale bed in the upper part of the Pilgrim dolomite; this shale bed may be the one that has localized some ore bodies about 20 feet below the top of the Pilgrim dolomite in the Elkhorn mine. The stratigraphic and structural features in the Keene area are similar to those in the Elkhorn mine. More comprehensive exploration of this area therefore appears to be warranted. 
DOLCOATH MINE AND KLONDYKE MINE

Gold-bearing telluride deposits in silicated carbonate rocks have been mined at the Dolcoath (pl. 1 no. 8 ) and Klondyke (no. 5) mines. The Dolcoath deposit is a replacement of an impure limestone bed in the Park shale. According to Knopf (1913, p. 133-134), the ore body is a stratum 12 to 18 inches thick, composed essentially of garnet (andradite), diopside, calcite, and epidote. Sulfide and telluride of bismuth (bismuthinite and tetradymite) carrying gold, together with chalcopyrite, constitute the ore minerals and are intergrown in small amounts both with silicate minerals and calcite. The deposit has been explored for about 40 feet along the outcrop and to a depth of at least 170 feet by an inclined shaft and a connected crosscut adit, both now inaccessible.

The Klondyke mine consisting of shallow surface workings and a shaft 56 feet deep with a. short level at the bottom, explores one or more silicated zones in the Jefferson dolomite. The silication is localized in part by bedding and in part by zones of shearing that cut sharply across bedding. Typically the silicated rock is an intergrowth of very fine grained pale-green diopside(?), coarsely bladed tremolite, coarse calcite, a silvery to green chlorite mineral, and scattered blebs of pyrite and chalcopyrite, more or less oxidized to limonite and malachite. The ore mineral is reported to be a gold-bearing telluride (Wade V. Lewis, oral communication).

\section{GOLDEN MOSS MINE}

The Golden Moss (p]. 1, no. 4) deposit, from which a small tonnage of high-grade gold ore has been mined, is in silicated beds at or near the horizon of the key limestone in the upper part of the Three Forks shale. The deposit was explored by a shaft that is now inaccessible. Judging from the dump, the ore consisted of silicified and in part silicated shale or limestone seamed and crusted by limonite and green secondary copper minerals.

\section{UNION MINE}

The Union mine (pl. 1, no. 2) is reported by Weed (1901, p. 506) to have yielded several railroad carloads of silver-lead ore. The position of the inaccessible shaft and adit suggests that the deposit is at or near the base of the Lodgepole limestone. Specimens of ore from the dump consist of banded recrystallized limestone with disseminated galena, honey-colored sphalerite, pyrite, and rare crusts of azurite and specks of an unidentified soft, dark-gray, lustrous metallic mineral. Thin stringers of siderite or ankerite, or both, cut some pieces of ore.

$408366-57-6$
C AND D MINE

The $\mathrm{C}$ and $\mathrm{D}$ mine (pl. 1, no. 3), according to unpublished reports and letters of various dates by W. R. Lindsay, L. S. Ropes, and C. C. Samuels (made available to the author by the late John Sloss of the Boulder Belle Mining Co., lessee of the mine), explored two types of deposits, one a strongly limonitic gold-lead replacement along bedding and the other a steeply dipping silver-bearing "vein." The deposits are in somewhat recrystallized Mission Canyon limestone near the south margin of a lobe of intrusive quartz monzonite from the Boulder batholith. The mine consists of a main haulage adit, an inclined shaft with two appended levels, and a winze from the adit with three appended levels. In 1950 only a part of the haulage adit was accessible. The accessible workings are parallel to and a short distance in the footwall of the bedded replacement ore body. The innermost workings are in moderately to intensely brecciated and clayseamed limestone that is believed to represent an area of collapsed caverns that formed during a period of Tertiary weathering subsequent to the deformation of the rocks and deposition of primary ore minerals. The position of the workings suggests that the bedded replacement deposit may terminate along the strike in this chaotic breccia zone. Furthermore, it is possible that the silver "vein" may terminate upward against this zone. Judging from maps of the inaccessible workings, most of the ore mined was from the bedded replacement body.

According to Weed $(1901$, p. 505) this deposit consists of low-grade pyritic ore with occasional bunches of galena. The present-day dumps contain abundant highly limonitic material that contains some admixed lead carbonate and sparse unoxidized kernels of galena.

\section{SWISSMONT AND PITTSMONT CLAIMS}

The Swissmont claim (pl. 1, no. 9) yielded 12,455 ounces of gold and 497 ounces of silver from 58,946 tons of ore mined in 1909 and 1921-1924. The Pittsmont claim yielded 3,759 ounces of gold and 2,699 ounces of silver from 9,634 tons of ore mined in 1914-1916. ${ }^{10}$ The ore was mined from an open pit or glory hole and from levels beneath it that were driven from a 200 foot (?) vertical shaft that is now filled with water. The ore body appears to have been a steeply dipping to vertical discordant lens in fractured, and possibly brecciated, Meagher limestone; at the surface the ore lens trends N. $35^{\circ} \mathrm{W}$. and was about 250 feet long and as much as 15 to 20 feet thick. The limestone walls

${ }^{10}$ Data from U. S. Bureau of Mines, Economics and Statistics Branch. Published with permission. 
of the ore body are somewhat fractured and seamed and stained with limonite.

\section{CARMODY-PAPESH MINE}

The Carmody-Papesh mine (pl. 1, no. 10) at Elkhorn explores a gold deposit in thermally metamorphosed Wolsey shale. The principal working, now inaccessible, is a crosscut adit with 500 feet of drift and an appended stope. The deposit is probably a high-temperature replacement controlled by the bedding. Ore from the dump is a dark-greenish-gray to black, fine-grained aggregate of silicate minerals, including abundant lustrous black hornblende, with intergrown pyrrhotite and sparse pyrite and chalcopyrite. Cyanidation tests of 4,800 tons of ore mined in $1935-36$ (? $)^{11}$ indicated an average recoverable gold content of about 0.14 ounces (Lancaster, H. M., 1936, written communication).

\section{BULWER AND ADJACENT CLAIMS}

For about half a mile north and south of Queen Gulch many prospect pits, shallow shafts, and short adits explore sporadic occurrences of copper minerals in thermally metamorphosed Cambrian and Devonian carbonate rocks adjacent to the east margin of the granodirite porphyry intrusive. Most of the ore on dumps consists of garnet-rich calcsilicate rock stained with malachite and limonite. The ore is reported to occur in northward-trending fractures in and adjacent to the contact-metamorphic aureole. The only record of production from this zone is that 53.6 tons of copper were recovered from 587 tons of ore shipped from the Bulwer (Bulware, Bouloware) claim (pl. 1, no. 14) between 1913 and $1920 .^{12}$

\section{TOURMALINE QUEEN PROPERTY}

On the Tourmaline Queen property (pl. 1, no. 12) opposite the mouth of Queen Gulch, a strongly fractured, altered, silicified and pyritic zone in andesitic volcanic rocks has been explored by two short adits, a bulldozer cut, and a number of diamond-drill holes. A significant tonnage of low-grade gold ore is indicated (Wade V. Lewis, oral communication), but to date no ore has been mined from the property. No other deposits of potential economic significance are known in the down-faulted block of Elkhorn Mountains volcanics west of Elkhorn Creek in the southwestern part of the Elkhorn district.

\section{SKXLINE MINE}

The Skyline mine (pl. 1, no. 14), on the Rare Outcrop No. 1 and Golden Butte claims near Leslie Lake ex-

\footnotetext{
11 Data from L. T. Carmody, owner ; published with permission.

12 Data from U. S. Bureau of Mines, Economies and Statistics Branch. Published with permission.
}

plores a steeply dipping elliptical breccia pipe in gently dipping andesitic fragmental volcanic rocks. The pipe consists of brecciated and fragmented andesite cemented by vuggy quartz and black tourmaline and grades outward into a sheath of pyritic andesite (fig. 4). At the surface the pipe has the form of a crude equilateral triangle whose sides are from 130 to 150 feet long and whose corners are somewhat rounded. It has been explored by two short adits, one with an appended 160foot winze and subdrifts, and four diamond-drill holes. Further exploration to outline the attitude of the pipe and the distribution of ore minerals within it was in progress in 1953. The ore within the pipe occurs as small pods and as altered and brecciated andesite that has been more or less replaced or cemented by quartz, tourmaline, pyrite, galena, sphalerite, and sparse chalcopyrite, arsenopyrite, and marcasite. The sulfide minrals with the possible exception of pyrite are probably later than the quartz and tourmaline, and their distribution appears to be much more limited than that of quartz and tourmaline.

The near-surface part of the pipe is a porous ironstained gossan from which all sulfide minerals have been leached.

\section{ELKHORN QUEEN MINE}

The Elkhorn Queen mine (pl. 2, no. 1) explores a steeply plunging pipelike ore body that is circular to elliptical in plan. The ore body ranges from about 200 to 1,200 square feet in plan and has been mined from the surface to a depth of 510 feet.

In the upper part of the mine the ore pipe is in granodiorite porphyry; just below the 300-foot level it cuts across a moderately northward dipping contact between the porphyry and hornfels of the Three Forks shale; and on the bottom level of the mine the ore pipe is entirely in hornfels that dips steeply southward. In the porphyry, control of the pipe is obscure, and the ore tends to grade out through strongly pryritic to relatively unaltered wall rock. In the hornfels the ore is typically bounded by faults of probable small postmineralization displacement. These faults have channelized oxidizing meteoric waters and may also have been significant in localizing the deposition of primary ore.

Ore consists of either porphyry or hornfels that has been more or less brecciated and replaced by quartz, black tourmaline, pyrite, galena, and sphalerite and subsequently incompletely oxidized to limonite, cerussite, smithsonite, calamine (?), and locally friable black manganese oxide. Knopf (1913, p. 139) noted that arsenopyrite is locally intergrown with galena. 


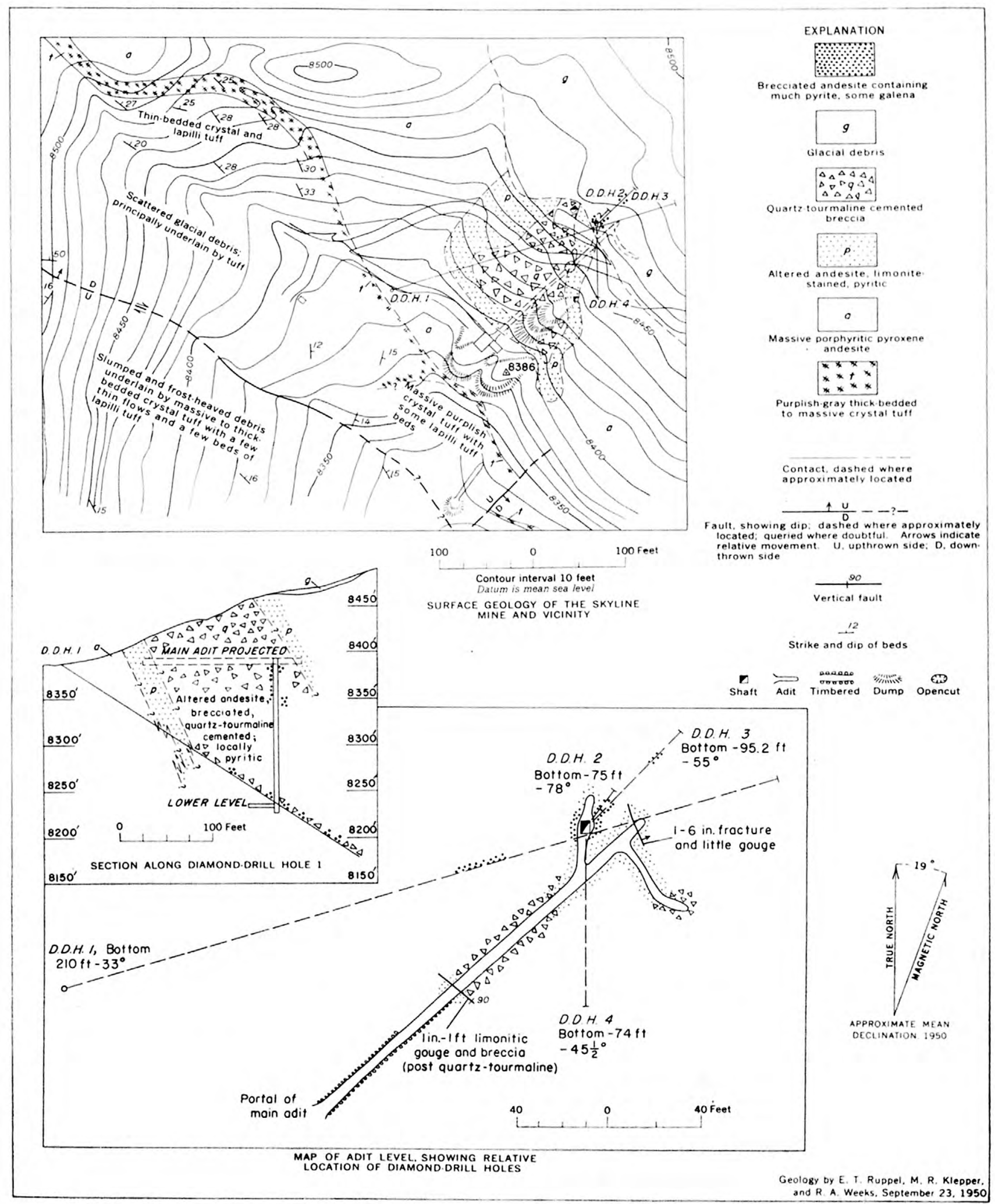

Figure 4.-Geology of the Skyline mine, Jefferson County, Mont. 
Production from 1901 to 1953 is reported ${ }^{13}$ to have been 17,500 tons of ore that yielded 4,940 ounces of gold, 122,020 ounces of silver, 1,775 tons of lead, 140 tons of zinc, and 9 tons of copper.

\section{TACOMA MINE}

The Tacoma mine (pl. 2, no. 2) consists of a number of caved pits and inaccessible short adits that explore narrow quartz veins in andesitic volcanic rocks. Stone (1911, p. 97$)$ states that a flat-lying siliceous cerussiteoearing vein 1 to 4 inches thick was exposed in a tunnel in 1910. Small pieces of limonitic vuggy quartz with sparse galena can be found on the dumps. The ore is reported to have been valuable chiefly for silver and gold.

\section{GOLDEN CURRY MINE}

The Golden Curry (Sourdough, Jacquemin) deposits (pl. 1, no. 11) have yielded substantial amounts of iron and gold. They were mined from an open pit and a number of underground workings. At the present time the pit is partly sloughed in and the underground workings are inaccessible. Four types of ore bodies are reported by Knopf (1913, p. 137), all in granite near a contact with metamorphosed limestone of Cambrian age. The four types were veins of magnetite, lodes of jasperlike hydrous ferric silicate, a massive magnetitepyrrhotite ore body with subordinate chalcopyrite intergrown with augite, and an elliptical mass of pyrrhotite and chalcopyrite in gangue of pyroxene. Production from this last type amounted to 2,000 tons of ore averaging $\$ 4$ per ton in gold, 2 percent copper, and 35 percent excess iron.

The mine was worked during the 1890 's chiefly for iron, but no record of the production during that period is available. It was again worked intermittently between 1904 and 1940 , and 98,442 tons of ore were shipped. This ore yielded 23,867 ounces of gold, 11,374 ounces of silver, and 325 tons of copper. ${ }^{14}$

\section{ELKHORN PEAK IRON DEPOSITS}

High-temperature replacement deposits of magnetite intergrown with more or less andradite garnet, epidote, axinite, calcite, quartz, actinolite, pyrite, specular hematite, and sparse chalcopyrite occur in thermally metamorphosed rocks in the lower 100 to 200 feet of the Elkhorn Mountains volcanics on the south and west flanks of Elkhorn Peak (pl. 1, no. 1). In this area the lower part of the volcanic sequence consists of andesitic fragmental rocks and a few thin flows with lenticular interbeds of pure and impure limestone. A thick silllike mass of alaskite, intruded along the base of the

${ }_{12}$ Data from U. S. Bureau of Mines, Economics and Statistics Branch. Published with permission.

14 Data from J. J. Rothfus, owner. Published with permission. volcanic sequence, separates it from the main body of quartz monzonite of the Boulder batholith to the west and south. The deposits are near the crest of a major anticline of which the west limb and part of the crestal area have been engulfed by alaskite and quartz monzonite.

The only magnetite deposits that have been exploited are on the west flank of the peak where a lobe from the alaskite sill crosscuts the volcanic sequence. Here, during the latter part of the 19th century, magnetite was mined from open pits and adits that are now caved and inaccessible. These workings are in beds stratigraphically beneath a thick unit of pure limestone that has been recrystallized to coarse-grained marble, but has not been significantly replaced by magnetite or silicate minerals. The distribution of the workings suggests that part of the magnetite occurred in impure calcareous sediments and part in altered pyritic andesite, and that at least some of the deposits were bedded replacements. Knopf reports $(1913$, p. 134) :

The magnetite is mainly intergrown with the garnet, but is also present as thin strings and quartz-magnetite veinlets traversing the garnet rock... The deposits are extensively oxidized, and much soft iron oxide, in part derived from the andradite, is present, obscuring the geologic relations.

\section{ELKHORN CREEK PLACER}

Placer gold was mined from an area 3,000 feet long and averaging about 200 feet wide along an abandoned channel of Elkhorn Creek (pl. 2, no. 4), which lies a few hundred feet east of its present flood plain. No record of the production is available.

\section{TIZER BASIN AREA}

CALLAHAN MINE

The Callahan (Golden Age, Deer Horn) mine (pl. 1, no. 18) explores a narrow vein in andesitic extrusive rocks. The vein strikes on the average $\mathrm{N} .50^{\circ} \mathrm{E}$. and dips from $50^{\circ} \mathrm{SE}$ to vertical, averaging about $70^{\circ} \mathrm{SE}$. In the central part of the explored area, the vein splits into two subparallel veins. The vein and its splits (pl. 7) have been explored for a length of about 1,500 feet and to a maximum depth of about 400 .feet by two adit levels and two short interconnected levels between them (pl. 8). From 1900 to 1953 a total of 6,810 ounces of gold, 7,860 ounces of silver, 7 tons of copper, 23 tons of lead, and 3 tons of zinc were recovered from about 11,000 tons of ore. ${ }^{15}$ Most of this ore was stoped from a discontinuous ore shoot on the south (hanging wall) split of the vein that was about 400 feet long and 250 feet high (pl. 8). A smaller quantity was mined from a steeply plunging shoot on the north (footwall) split

${ }^{15}$ Data from U. S. Bureau of Mines, Economics and Statistics Branch. Published with permission. 
of the vein that was about 100 feet long and 200 feet high. Most of the ore that was mined was oxidized. On the bottom level of the mine, where the vein is incompletely oxidized, little minable ore has been found.

The veins are as much as 6 feet thick but average between 2 and 3 feet thick and consist of alternate strands of gouge, altered pyritic andesite, and vuggy quartz that, below the oxidized zone, contains sparst pyrite, galena, sphalerite, and chalcopyrite and rare specks of gold and tetrahedrite(?). A gold-bismuth telluride is reported to occur locally (Nat Chamberlin, oral communication). Typically the andesitic wall rock is somewhat bleached and pyritic for a few feet adjacent to the vein. Although narrow high-grade lenses of gold ore have been found, the average grade of minable widths of ore has been about half an ounce of gold.

As is shown in plate 7, three general sets of fractures cut the andesitic extrusive rocks, an early northwestward-trending set, a N. $60-85^{\circ} \mathrm{E}$. intermediate set, and the youngest set including the hanging-wall vein that trending about N. $40-50^{\circ} \mathrm{E}$. The bulk of the mineralization has occurred in the youngest set, with smaller amounts in the intermediate set. The oldest set is only weakly mineralized. Favorable zones were reported (Nat Chamberlin, oral communication) to have occurred at and along rolls in the dip of the hanging-wall vein, with the best grade and greatest width of ore in the more gently dipping part of the structure. Rocks in the area of the intersection of the hangingwall vein and footwall vein are highly fractured, and served as a locus of mineralization.

A small mill has been operated on the property from time to time.

\section{CENTER REEF MINE}

The Center Reef (Ballard) mine (pl. 1, no. 19) explores a narrow vein of siliceous gold ore in gently dipping andesitic fragmental rocks of the Elkhorn Mountains volcanics. The vein trends N. $70^{\circ} \mathrm{E}$., $\operatorname{dips} 70^{\circ}$ SE. to vertical, and in internal structure and mineralogy closely resembles the Callahan veins. It has been explored discontinuously for at least 500 feet along the strike and to a depth of 230 feet by shallow surface workings and two crosscut adits, the lower of which is inaccessible. Discontinuous shoots of oxidized ore were stoped for about 200 feet along the vein between the upper adit level and the surface, a vertical distance of about 110 feet. Recorded production of 976 tons of ore yielded 2,726 ounces of gold, 6,842 ounces of silver, and 5 tons of lead. ${ }^{16}$

\footnotetext{
${ }^{10}$ Data from U. S. Bureau of Mines, Economics and Statistics Branch. Published with permission.
}

Commercial ore is said to bottom at about the elevation of the upper adit (Nat Chamberlin, oral communication), which is probably the lower limit of thorough oxidation.

\section{BELLE MINE}

A narrow vein in andesitic crystal tuff has been explored by a 700-foot adit at the Belle mine (pl. 1, no. 16) near the mouth of Moose Creek. The vein has been traced at the surface for about 2,000 feet. In the accessible part of the adit the vein trends N. $75^{\circ}-80^{\circ}$ E. and dips from $50^{\circ} \mathrm{SE}$ to vertical. In places its consists of one or more bands of quartz as much as 6 inches thick with smaller amounts of calcite, pyrite, and galena. In other places the vein is a zone of altered andesitic rock as much as 6 feet thick containing disseminated pyrite and galena. Malachite stain is common in the oxidized part of the vein. Typically the rock adjacent to the vein is bleached and pyritic andesitic tuff. The ore produced until 1950 is reported to have averaged 0.77 ounce of gold, 17 ounces of silver, and 17 percent lead, and to have had a total value of $\$ 16,000 .{ }^{17}$

\section{BLACK JACK CLAIM}

A pipelike (?) deposit on the Black Jack claim (pl. 1, no. 15) may be similar to the Skyline deposit but pyrite is the only metallic mineral that has been found in four shallow prospect shafts. Stone (1911, p. 92-93) states

*** the claim is interesting as it is located on a mass of brecciated andesite 75 feet in diameter, carrying a large amount of rusty quartz and radiating black crystals of tourmaline.

Sparse epidote is associated with the quartz and tourmaline. Part of the pyrite is well-formed crystals in vugs in tourmaline and quartz.

\section{WILSON CREEK AND CROW CREEK PLACER DEPOSITS}

Small placer operations have been carried on intermittently at several localities along Wilson Creek and for several hundred yards along Crow Creek (pl. 1, no. 17) below the mouth of Wilson Creek. None of the early operations were mechanized, but in recent years small scale mechanical operations have been conducted in a few places. Total production has probably been small. Narrow veins along the contact zone between andesite and quartz monzonite that have been prospected on and west of Bullock Hill (pl. 1) were probably the source of the placer gold in the middle and upper parts of Wilson Creek. Part of the placer gold near the mouth of Wilson Creek and along Crow Creek may have been derived from the Callahan veins.

Small amounts of gold also occur in Little Tizer Creek just below the outlet of 'Tizer Lake.

\footnotetext{
17 Data from Jerlie Eckerson, owner; published with permission
} 


\section{OTHER AREAS}

\section{MCFADGEN-NAVE PROSPECT}

In 1951 and 1952 exploration along the north slope of Eureka Creek above the mouth of Teakettle Creek disclosed several narrow lead-silver veins in andesite (pl. 1, no. 20). The strongest vein trends N. $85^{\circ} \mathrm{E}$., dips about $60^{\circ} \mathrm{SW}$, and consists of a stringer of galena and cerussite from 3 to 9 inches wide in a zone of altered andesite from 2 to 6 feet wide. Several northwestwardtrending steep veins with similar mineralization were also exposed in the course of this work. A shipment of ore was made from one deposit (H. J. McFadgen, oral communication).

\section{KATIEDID PROSPECT}

The Katiedid prospect (pl. 2, no. 8) consists of two vertical shafts about 50 feet deep and a short adit, all exploring an easterward-trending essentially vertical quartz vein in the Greyson shale. The quartz vein has an exposed maximum thickness of about 3 feet, an average thickness of about 1.5 feet, and contains slight to moderate amounts of bornite and chalcopyrite, largely oxidized to malachite, melaconite, cuprite (?), and sparse pyrite, partly oxidized to limonite. Production, if any, has been slight.

\section{J AND F NO, I CLATM}

On the $J$ and F No. 1 (Valley View, Silver Hill) claim (pl. 3, no. 1) a number of pits, short adits and shallow shafts explore silicified and altered Greyson argillite at and near the contact with a 50-foot thick diorite sill. Sparse galena was the only ore mineral found on the dumps. Production, if any, has been small.

\section{SUMMIT(?) CLAIM}

Stone (1911, p. 92) briefly described prospects on a bald knob between Swamp Creek and Sand Creek ( $\mathrm{pl}$. 1, no. 21). No work appears to have been done at these prospects since his examination, and at the present time all workings are caved. The principal workings appears to have been an inclined shaft along argillaceous beds in the lower part of the Morrison formation. The dump contains silicified shale, jasper, and limonite, but no ore minerals were recognized.

\section{BONANZA MINE}

The Bonanza mine (pl. 1, no. 22) explored galenabearing veins in the upper part of the Mission Canyon limestone on the crest of the major domal structure of the southern Elkhorn Mountains. Stone (1911, p. 91) reported that the ore was along bedding that dips $25^{\circ} \mathrm{N}$., and that the workings consisted of about ten tunnels. All were relatively short and are now caved. Ore specimens selected from the dumps contain galena, in part oxidized to cerussite, intergrown with milky quartz, limonite, coarsely crystalline calcite, and sparse sphalerite. The largest vein fragment found consists of a 2 -inch band of quartz with abundant galena and a 4 -inch band of coarsely crystalline calcite. Stone noted that the ore was valuable principally for silver.

\section{Passover Claim}

On the Passover claim (pl. 2, no. 3) on the west bank of Dry Creek, an inclined shaft explores a small pipelike replacement body in a dolomite bed in the Quadrant formation. The pipe probably did not exceed 3 feet by 15 feet in cross section and was mined to a depth of about 60 feet. Sparse crystals of galena and films of malachite were observed in limonite and jasper on the dump. Shipments in 1915, 1917-19, 1936, and 1951, totaled 171 tons of ore from which were recovered 1 ounce of gold, 3,100 ounces of silver, and 35 tons of lead. ${ }^{18}$

\section{SPAR MINE}

The Spar mine (fig. 5 and pl. 2, no. 5) explores a replacement deposit in the middle part of the Jefferson dolomite, near the crest of the major dome. At the mine the beds trend about N. $10^{\circ} \mathrm{W}$. and $\operatorname{dip} 20^{\circ}-30^{\circ} \mathrm{W}$. The ore is in a replaced bed that is 3 to 5 feet thick. This bed probably was more calcareous and perhaps more permeable than other carbonate beds in the middle part of this predominantly dolomitic formation. Thin shale beds underlie and overlie it. Commercial ore appears to be limited to a shoot that rakes gently north and is bounded by a number of closely spaced steepdipping northward-trending fractures along which displacement has been slight. The width of the ore body ranges from 25 to 50 feet; the length is unknown, although the body has been followed down the rake from the outcrop for about 325 feet. High-grade ore is typically 2 feet or less in thickness and is either overlain or underlain, or both, by a few inches to 2 feet of siliceous low-grade ore. Ore consists of carbonate rock that has been replaced by barite, quartz, subordinate amounts of dolomite and calcite, and sparsely disseminated tetrahedrite argentite, sphalerite, and galena. The primary ore has been partially oxidized, with the formation of embolite or cerargyrite, films of black manganese oxide, malachite and at least one unidentified earthy greenish-yellow mineral.

Production from 1900 to 1953 totaled about 2,670 tons of ore from which about 110 ounces of gold, 63,700 ounces of silver, 3 tons of zinc, and less than 1 ton each of lead and copper ${ }^{19}$ were recovered.

18 Data from U. S. Bureau of Mines, Economics and Statistics Branch. Published with permission.

${ }^{19}$ Data from U. S. Bureau of Mines, Economics and Statistics Branch, and I. G. Irving, lessee; published with permission. 


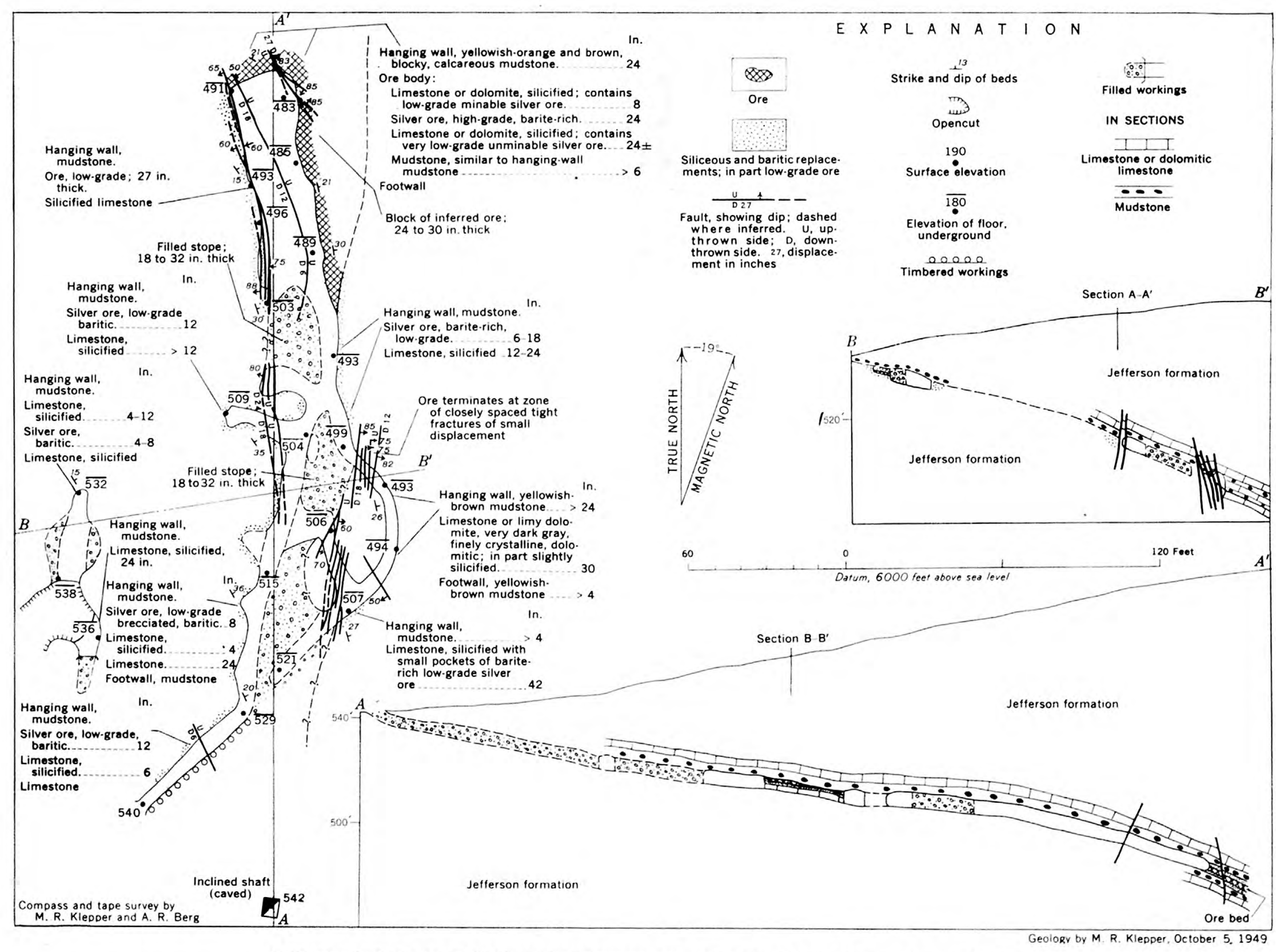

Fratre 5.-Geologic map of the Spar mine, SW $1 / 4$ NE $1 / 4$ sec. 36, T. 6 N., R. 2 W., Jefferson County, Mont. 


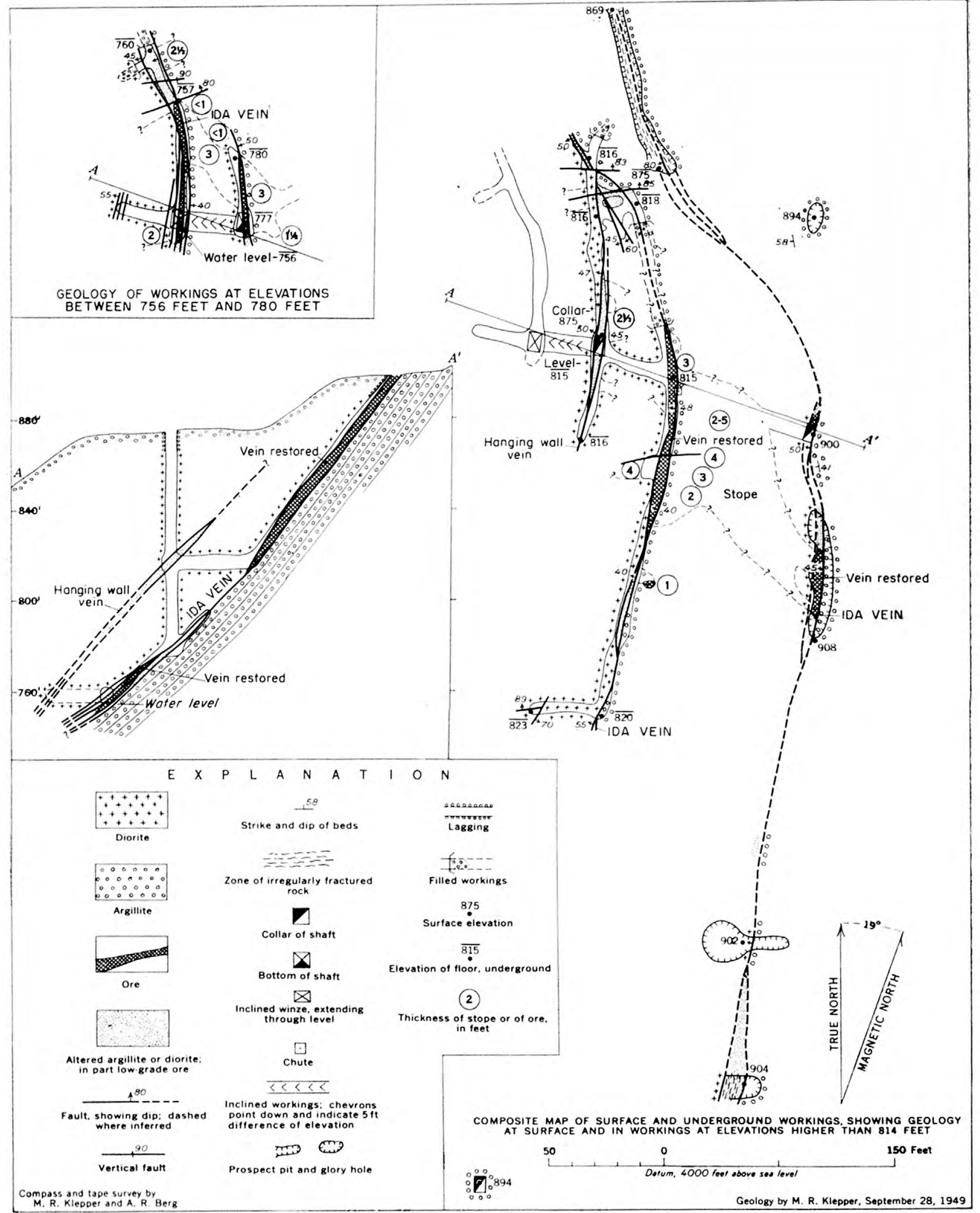

Figure 6.-Geologic map of the Ida mine, SW $1 / 4$ sec. 22, T. 4 N., R. 2 W., Jefferson County, Mont. 


\section{ROTHFUS IRON MINE}

The Rothfus iron mine (pl. 2, no. 6) is in thermally metamorphosed Meagher limestone at and near the borders of a small stock of diorite porphyry and sill-like and dikelike offshoots from it. The principal ore zone appears to have been along the east margin of the stock, where ore was stoped intermittently above an adit level that was at least 600 feet long. All workings, except surface pits are now inaccessible. Ore consists of magnetite and hematite, in part intergrown with dark-redbrown garnet, epidote, diopside, quartz, calcite, and sparse pyrite. Malachite films are present locally. Part of the ore appears to have formed a nearly continuous tabular band that lay along the contact and cut across bedding, and part replaced favorable beds in the gently dipping limestone sequence. The ore was mined for smelter flux and is said to have contained about $\$ 1$ a ton in gold (Stone 1911, p. 95-96).

\section{PARKER GROUP}

On the Parker group of claims (Silver Bell, Ned, Globe) (pl. 2, no. 7) along and south of Johnny Gulch, scattered limonitic replacement deposits in the upper part of the Meagher limestone have been explored. According to Winchell $(1914$, p. 181) the ore was chiefly argentiferous galena in a gangue of siderite, quartz, hematite, limonite, and pyrolusite. The deposits now exposed consist of limonite and sparse black manganese oxides, formed at least in part from oxidation of carbonate minerals. Some of the replacements appear to be localized along fractures of diverse trend and some along favorable beds; all are small. In the vicinity of the deposits a sill of diorite porphyry is present at the base of the Park shale, which overlies the Meagher limestone. The workings comprise a number of short adits, shallow inclines, and prospect pits, and a sinuous adit driven from the level of Johnny Gulch, presumably to explore beneath the most promising surface showings. Small caverns that are filled with bedded and unbedded mud, sand, gravel, and blocky rubble border many of the faults and joints exposed in this adit. These cavern deposits seem to have formed partly by collapse of leached fracture zones and partly by deposition from running or ponded water. They were probably formed at the time that the small sulfide ore bodies were oxidized, perhaps during the pre-Oligocene erosion interval. Stone $(1911$, p. 96$)$ reports that 1,000 tons of ore were shipped from the Silver Bell mine to a smelter at Wickes, Mont.

\footnotetext{
${ }^{20}$ Data from U. S. Bureau of Mines, Economics and Statistics Branch ; published with permission.
}

\section{IDA MINE}

The Ida mine (pl. 3, no. 2) explores two parallel veins that trend in a broad are from N. $20^{\circ}$ E. at the south end of the mine to N. $20^{\circ} \mathrm{W}$. at the north end (fig. 6). Both veins dip $50^{\circ} \mathrm{W}$. The principal vein is along the footwall contact of a diorite sill near the contact between the Greyson shale and the Spokane shale; the other vein is within the diorite sill. The principal vein has a maximum thickness of 5 feet and averages about $2 \frac{1}{2}$ feet thick. It consists of one or more strands of fault clay and lenses of quartz and silicified argillite that contain galena, sphalerite, and limonite after pyrite. The other vein is similar but thinner. The veins have been explored for a length of 300 feet by a 100 -foot vertical shaft with a level 60 feet below the collar and a level and winze at the bottom. During the period 1915-1953 ore shipments totaling 1,332 tons yielded 107 ounces of gold, 20,767 ounces of silver, 1 ton of copper, 89 tons of lead and 24 tons of zinc. $^{20}$ Most of this ore was mined from a single shoot on the principal vein. This shoot rakes northwest, averages about 3 feet thick, ranges from 10 to 50 feet in breadth, and has been mined discontinuously for 200 feet along the rake.

\section{LITERATURE CITED}

Alden, W. C., 1954, Physiography and glacial geology of western Montana and adjacent areas: U. S. Geol. Survey Prof. Paper 231.

Atwood, W. W., 1916, Physiographic conditions at Butte, Mont., and Bingham Canyon, Utah, when the copper ores in the districts were enriched: Econ. Geol., v. 11, no. 8, p. 697-740.

Barrell, Joseph, 1901, The microscopical petrography of the district, in Weed, W. H., Geology and ore deposits of the Elkhorn mining district: U. S. Geol. Survey 22 nd annual report, pt. 2, p. 511-549.

Berry, G. W., 1943, Stratigraphy and structure at Three Forks, Mont. : Geol. Soc. America Bull., v. 54, p. 1-30.

Billingsley, Paul, 1915, The Boulder batholith of Montana: Am. Inst. Min. Eng. Trans., v. 51, p. 31-47.

Billingsley, Paul, and Grimes, J. A., 1918, Ore deposits of the Boulder batholith of Montana: Am. Inst. Min. Eng. Trans., v. 58, p. $284-368$.

Blackstone, D. L., Jr., 1940, Structure of the Pryor Mountains, Mont. : Jour. Geology, v. 48, p. 590-618.

Brown, R. W., 1946, Fossil plants and Jurassic-Cretaceous boundary problem in Montana and Alberta: Am. Assoc. Petroleum Geologists Bull., v. 30, p. 238-248.

Cobban, W. A., 1945, Marine Jurassic formations of Sweetgrass arch, Montana: Am. Assoc. Petroleum Geologists Bull., v. 29 , p. $1262-1303$.

Cobban, W. A., and Reeside, J. B., Jr., 1951, Lower Cretaceous ammonites in Colorado, Wyoming, and Montana [abstract] : Am. Assoc. Petroleum Geologists Bull., v. 35, p. 1892-1893.

1952, Correlation of the Cretaceous formations of the western interior of the United States: Geol. Soc. America Bull., vol. 63, p. 1011-1044. 
Collier, A. J., and Cathcart, S. H., 1922, Possibility of finding oil in laccolithic domes south of the Little Rocky Mountains, Mont.: U. S. Geol. Survey Bull. 736-F, p. 171-178.

Condit, D. D., 1918, Relations of late Paleozoic and early Mesozoic formations of southwestern Montana and adjacent parts of Wyoming: U. S. Geol. Survey Prof. Paper 120-F, p. 111-121.

Condit, D. D., Finch, E. H., and Pardee, J. T., 1928, Phosphate rock in the Three Forks-Yellowstone Park region, Montana : U. S. Geol. Survey Bull. 795-G, p. 147-209.

Corry, A. V., 1933, Some gold deposits of Broadwater, Beaverhead, Phillips, and Fergus Counties, Mont.: Mont. Bur. Mines and Geol. Mem. 10, p. 16-23.

Deiss, C. F., 1935, Cambrian-Algonkian unconformity in western Montana: Geol. Soc. America Bull., v. 46, p. 95-124.

- 1936, Revision of type Cambrian formations and sections of Montana and Yellowstone National Park: Geol. Soc. America Bull., v. 47, p. 1257-1342.

Dorf, Erling, and Lochman, Christina, 1940, Upper Cambrian formations in southern Montana: Geol. Soc. America Bull., v. 51, p. 541-556.

Emmons, W. H., and Calkins, F. C., 1913, Geology and ore deposits of the Philipsburg quadrangle, Mont.: U. S. Geol. Survey Prop. Paper 78.

Fenton, C. L., and Fenton, M. A., 1937, Belt series of the north ; stratigraphy, sedimentation, paleontology: Geol. Soc. America Bull., v. 48, p. 1873-1969.

Freeman, V. L., Ruppel, E. T., and Klepper, M. R., in preparation, Geology of part of the Townsend Valley, Broadwater and Jefferson Counties, Mont. : U. S. Geol. Survey Bull.

Gardner, L. S., Hendricks, T. A., Hadley, H. D., and Rogers, C. P., Jr., 1946, Stratigraphic sections of Upper-Paleozoic and Mesozoic rocks in south-central Montana: Mont. Bur. Mines and Geology Mem. 24.

Hanson, A. M., 1951, Dry Creek formation in southwestern Montana [abstract] : Geol. Soc. America Bull., v. 62, p. 1536.

1952, Cambrian stratigraphy in southwestern Montana : Mont. Bur. Mines and Geology Mem. 33, p. 1-46.

Imlay, R. W., Gardner, L. S., Rogers, C. P., Jr., and Hadley, H. D., 1948, Marine Jurassic formations of Montana: U. S. Geol. Survey prelim. oil and gas chart no. 32 .

Kemp, J. F., and Billingsley, Paul, 1921, Sweet Grass Hills, Mont.: Geol. Soc. America Bull., v. 32, p. 437-478.

Klepper, M. R., 1950, A geologic reconnaissance of parts of Beaverhead and Madison Counties, Mont. : U. S. Geol. Survey Bull. 969-C, p. 55-84.

Knopf, Adolph, 1913, Ore deposits of the Helena mining region : U. S. Geol. Survey Bull. 527.

1936, Igneous geology of the Spanish Peaks region, Colorado: Geol. Soc. America Bull., v. 47, p. 1727-1784.

Lochman, Christina, 1950, Status of Dry Creek shale of central Montana: Am. Assoc. Petroleum Geologists Bull., v. 34, p. $2200-2222$.

Lyons, J. B., 1944, Igneous rocks of the northern Big Belt Range, Mont. : Geol. Soc. America Bull., v. 55, p. 445-472.

Mertie, J. B., Jr., Fischer, R. P., and Hobbs, S. W., 1951, Geology of the Canyon Ferry quadrangle, Mont.: U. S. Geol. Survey Bull. 972.

Pardee, J. T., 1925, Geology and ground-water resources of Townsend Valley, Mont.: U. S. Geol. Survey Water-Supply Paper 539.

1950, Late Cenozoic block faulting in western Montana : Geol. Soc. America Bull., v. 61, p. 359-406.
Pardee, J. 'T., and Schrader, F. C., 1933, Metalliferous deposits of the greater Helena mining region: U. S. Geol. Survey Bull. 842 .

Parsons, W. H., 1942, Origin and structure of the Livingston igneous rocks, Montana: Geol. Soc. America Bull, v. 53, p. 1175-1186.

Peale, A. C., 1893, The Paleozoic section in the vicinity of Three Forks, Mont. : U. S. Geol. Survey Bull. 110.

- 1896, Description of the Three Forks sheet: U. S. Geol. Survey Geol. Atlas Three Forks folio (no. 24).

Read, H. H., 1931, Geology of central Sutherlandshire (explanation of sheets 108 and 109): Geol. Survey of Scotland, p. 1-238.

Read, H. H., Phemister, J., and Ross, G., 1926, The geology of Strath Oykell and lower Loch Shin (explanation of sheet 102) : Geol. Survey of Scotland, p. 1-220.

Read, H. H., Ross, G., and Phemister, J., 1925, The geology of the country around Golspie, Sutherlandshire (explanation of sheet 103) : Geol. Survey of Scotland, p. 1-143.

Richards, P. W. and Prichard, G. E., 1950, The Livingston formation: Billings Geol. Soc. First Annual Field Conference, p. 49-55.

Ross, C. P., 1949, The Belt problem: Washington Acad. Sci. Jour., v. 39, no. 3.

Rubey, W. W., 1929, Origin of the siliceous Mowry shale of the Black Hills region: U. S. Geol. Survey Prof. Paper 154-D, p. 153-170.

Shapiro, Leonard, and Brannock, W. W., 1956, Rapid analysis of silicate rocks: U. S. Geol. Survey Bull. 1036-C, p. 19-56.

Sloss, L. L., 1950, Paleozoic sedimentation in Montana: Am. Assoc. Petroleum Geologists Bull., v. 34, p. 423-451.

Sloss, L. L., and Hamblin, R. H., 1952, Stratigraphy and insoluble residues of Madison group (Mississippian) of Montana : Am. Assoc. Petroleum Geologists Bull., v. 36, p. 305-335.

Sloss, L. L. and Laird, W. M., 1947, Devonian system in central and northwestern Montana: Am. Assoc. Petroleum Geologists Bull., v. 31, p. 1404-1430.

Stone, R. W., 1911, Geologic relations of ore deposits in the Elkhorn Mountains, Mont.: U. S. Geol. Survey Bull. 470-B, p. $75-98$.

Stone, R. W. and Calvert, W. R., 1910, stratigraphic relations of the Livingston formation of Montana: Econ. Geology, v. 5, p. 551-557, 652-669, and 744-764.

Tourtelot, H. A. and Thompson, R. M., 1948, Geology of the Boysen area, central Wyoming: U. S. Geol. Survey oil and gas inv. prelim. map no. 41, sheet 2 .

Walcott, C. D., 1899, Pre-Cambrian fossiliferous formations: Geol. Soc. America Bull., v. 10, p. 199-244.

Weed, W. H., 1893, The Laramie and overlying Livingston formation of Montana: U. S. Geol. Survey Bull. 105.

- 1901, Geology and ore deposits of the Elkhorn mining district, Jefferson County, Mont.: U. S. Geol. Survey 22d Ann. Rept., pt. 2, p. 399-550.

1912, Geology and ore deposits of the Butte district, Mont.: U. S. Geol. Survey Prof. Paper 74.

Wentworth, C. K., and Williams, Howell, 1932, The classification and terminology of the pyroclastic rocks: Natl. Research Council Bull. 89, p. 19-53.

Williams, James Steele, 1948, Mississippian-Pennsylvanian boundary problems in the Rocky Mountain Region: Jour. Geol., v. 56, p. 327-351.

Winchell, A. N., 1914, Mining districts of the Dillon quadrangle, Mont.: U. S. Geol. Survey Bull. 574. 


\section{N DEX}

Page

Abstract

Acknowledgments.

Alaskite, chemical analysis

in the Boulder batholith.

Alaskitic granite, chemical analysis.

Aldrich Gulch, stratigraphic section.

Alluvium.

Altitude of the area.

Amsden formation, lithologic character.

metamorphism of

thickness.

Analyses of igneous rock

Aplite, chemical analysis in the Boulder batholith

Argillite.

Axinite. See also mine descriptions.

Ballard mine. See Center Reef mine.

Barite

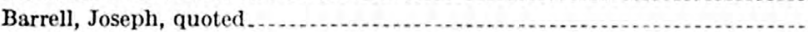

Belle mine.. rocks of .................................................................. $5-6$ See also Greyson shale, Spokane shale, and Empire shale.

Bentonite

Berthold, S. M., chemical analyses by.

$34,47,49$,

Biotite-hornblende diorite, chemical analyses

Biotite-hornblende granodiorite, chemical analysis

Black Butte stock, chemical analysis of rocks from description.

ckjack minc

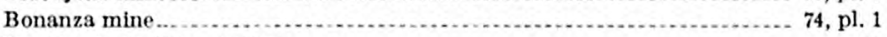

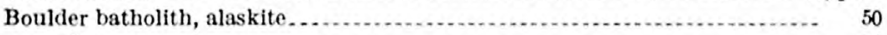

aplite 50

chemical analyses of rocks............................................. 49

contact metamorphic deposits near................................ 64

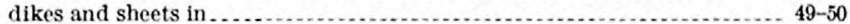

granodiorite . ................. 48-49

quartz monzonite..................................................... 48-49

Boulder River, Oligocene sediments along .............................. 42

Bouloware mine. See Bulwer mine.

Brambilla, Dante E., stratigraphic sections measured by .................. 29-30

Breccia, in Elkhorn Mountains volcanics

in Mission Canyon limestone

Breccia deposits, pipelike mineral

Brown, R. W., fossils identified by quoted.

Bulwer mine. 64,70 , pl. 1

Calesilicate rock

$52-55$

Callahan mine.

$2-73$, pls. $1,7,8$

Cambrian system, rocks of ........... 6-14 See also Flathead quartzite, Wolsey shale, Meagher limestone, Park shale Pllgrim dolomite, and Red Lion formation.

C. and D. mine

Carboniferous systems, rocks of See also Lodgepole limestone, Mission Canyon limestone, Amsden formation, and Quadrant formation.

Carmody-Papesh mine. 64,70, pl. 1

Cemetery Ridge stock, chemical analyses of description. mineral composition

Center Reel mine.

$1-2$
$3-4$

49

49

1

4

Page

43

Clancy quadrangle, mineral deposits in the south half ..................... 65

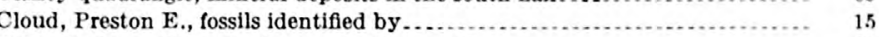

Colorado formation, correlation of subunits of ............................. 26

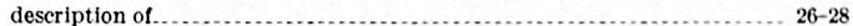

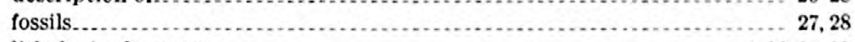

lithologic character........................................ 26-27, 28

lower black shale unit ............. 26-27

siliceous mudstone and sandstone unit . . . . . . . . . . .

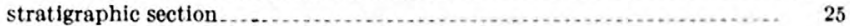

subunits of... 26

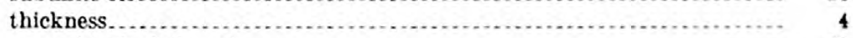

upper black shale unit.......................................... 28

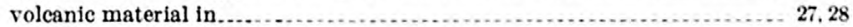

Conglomerate, of uncertain age ................................... 42

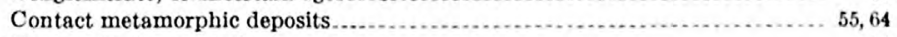

Cooper, G. A., quoted

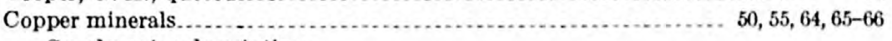
See also mine descriptions.

Correlation chart, of Cretaceous rocks of western interior United States....... 26

Cretaceous rocks, correlation of ...................................... 26

Cretaceous system, boundary between Jurassic system and ................. 23

general description of rocks.....

See also Kootenai formation, Colorado formation, Slim Sam formation, and Elkhorn Mountains volcanics.

Crow Creek placer deposit .......................................

\section{$\mathrm{D}$}

Deer Horn mine. See Callahan mine.

Devils Fence quadrangle, mineral deposits in north half . .............. $65-66$

mineral deposits in southeast part ........................................

Devonian system, Three Forks shale.

Dikes

$45,49,52$

Diorite porphyry, alteration...................................... 45

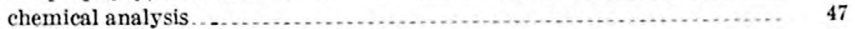

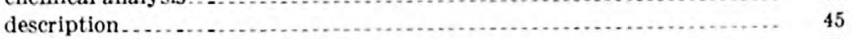

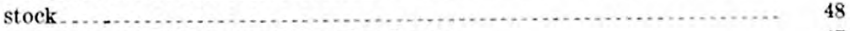

at junction of Elkhorn and Turnley Creeks........................ 47

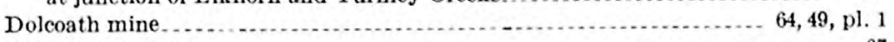

Dolomite deposits . . . . . . . . . . . .

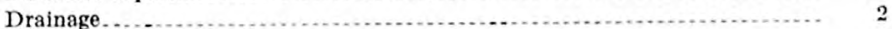

E

Elkhorn, Mont., analyses of rocks near .....

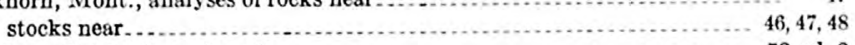

Elkhorn Creek placer deposit.......................................... 2

Elkhorn district, descriptions of mines and prospects . . . . . . . . . .

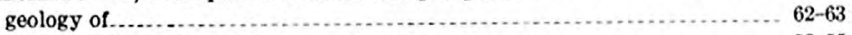

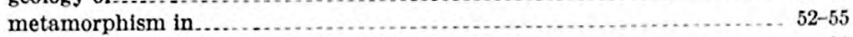

production .

types of metallic mineral deposits ................................ $63-64$

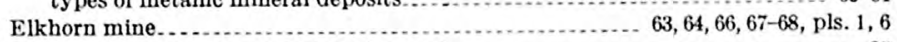

Elkhorn Mountains, correlation of rocks in ........................... 26

Elkhorn Mountains volcanics, age of . . . . . . . . . . . . . .

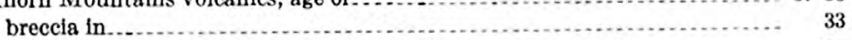

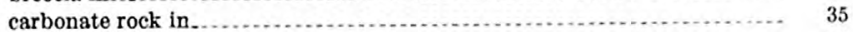

chemical analysis of welded tuff .................................. 34

composition of . . . . . . . .

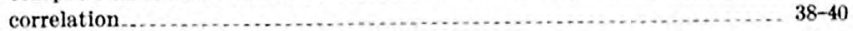

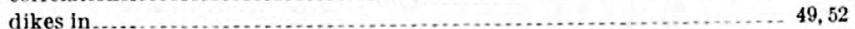

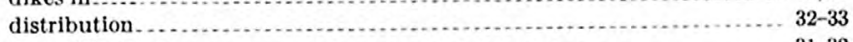

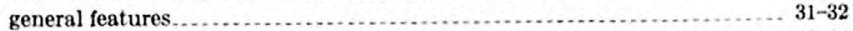

lava flows in .......................... 33-34

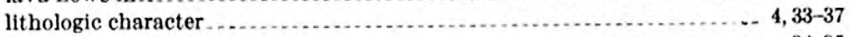

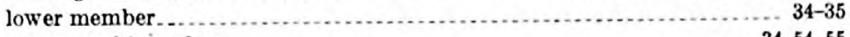

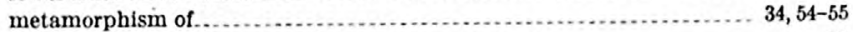

middle member 
Elkhorn Mountains volcanics-Continued relation to older rocks

sequence of units. -

stratigraphic sections

thickness.

tuff in ...

upper member.

volcanic conglomerate in

welded tuff in. .

Elkhorn Peak iron deposit, effects of additive metamorphism

Elkhorn Peak Iron mine.

Elkhorn Queen mine

Empire shale, lithologic character

relation to the Spokane shale.

thickness.

\section{F}

Fan deposits

$42,44,62$

Faults, classification.

early-formed.

Horse Gulch fault

of uncertain origin

recurrent movement.

related to emplacement of older intrusive rocks.

related to the emplacement of younger intrusive rocks.

related to the main episode of folding.

Tacoma Gulch fault

younger than the batholith

Felsite dikes

Flathead quartzite, description

lithologic character

relation to rocks of the Belt series

stratigraphic sections...

thickness.

use in manufacture of cement

Folds, description....

relation to localization of ore

Fossil algae

Fossils, in the Colorado formation.

in Elkhorn Mountains volcanics.

in Pilgrim dolomite..

in Red Lion formation.

in Slim Sam formation.

in the Swift formation

in Three Forks shale

Freeman, V. L., sections measured by

G

Gabbro, chemical analyses

Garnet

See also mine descriptions.

Geologic formations, generalized section of

Geomorphology

Glacial deposits

Glaciation.

Glaciers, valley.

Globe claim. See Parker group of claims.

Gold. See also mine descriptions.

Golden Age mine. See Callahan mine.

Golden Curry mine........ 64, 72, pl. 1

Golden Moss mine................................................. 64, 69, pl. 1

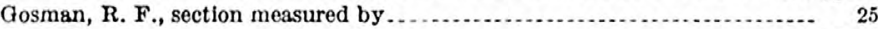

Granodiorite, chemical analyses of....................................... 47, 49, 50

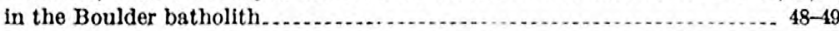

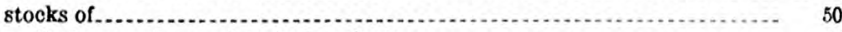

Granodiorite prophyry, chemical analysis............. 47

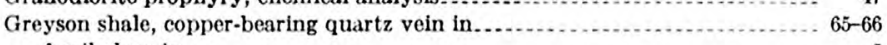

fossil algae in.

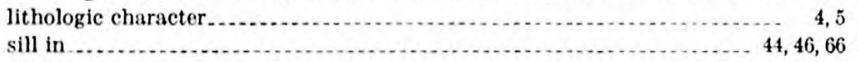

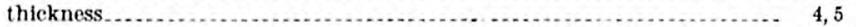

\section{H}

Holter mine. See Elkhorn mine.

Hornblende lamprophyre, description...

Hornblende monzonite, chemical analysis

Hornblende phenocrysts.

Hornfels.

40

$\mathrm{H}$

orst

\section{I}

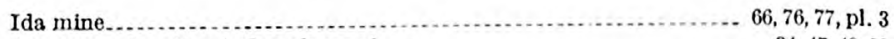

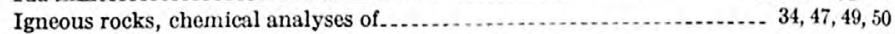
quantitative description................................................ 51

Indian Creek, stratigraphic sections in ..........

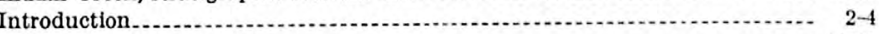

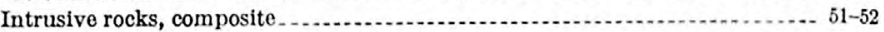

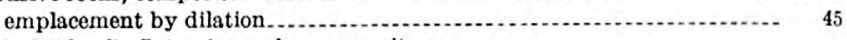

hybrid. See Intrusive rocks, composite.

older group............... 44-45

younger group............... $46-51$

See also Stocks, Sills, Plutons, Dikes, and Boulder batholith.

Iron ore.

See also mine descriptions.

Jacquemin mine. See Golden Curry mine.

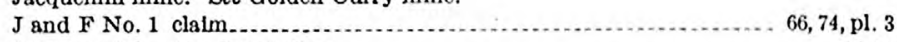

Jefferson dolonite, description............................................... 15

lithologic character . . . . . . .

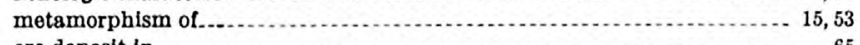

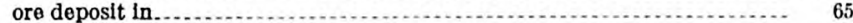

See also Spar mine.

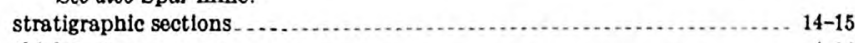

thickness .................................................... 4,14

Johnny Gulch, stratigraphic sections in ......................... 10,11,13,25

Jurassic system, boundaries of . rocks of. See Swift formation and Morrison formation.

$\mathbf{K}$

Kame terraces...

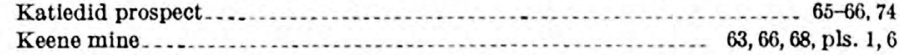

Klepper, M. R., stratigraphic sections measured by . ..... 16. 17, 18-19, 20-21, 30-31

Klondyke mine
Knopf, Adolph, quoted.

Kootenai formation, boundary between Cretaceous and Jurassic................. 25

description ...

lithologic character. . . . . . . . . .

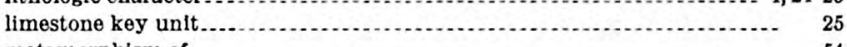

metamorphism of........................................................ 54

thickness . . . .

\section{L}

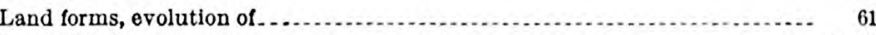

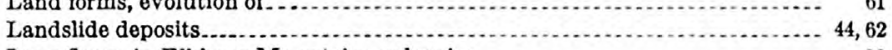

Lava flows, in Elkhorn Mountains volcanics. ................................... 33

Lead. See also mine descriptions.

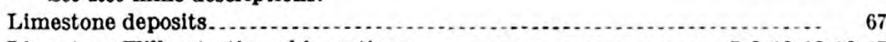

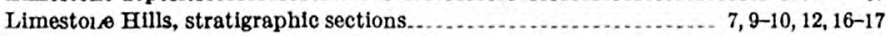

Literature cited . . . . . . . . . . . . . . .

Lithologic control of topography

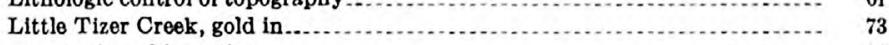

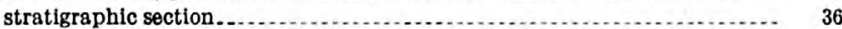

Location of area ..................................................... 2,3

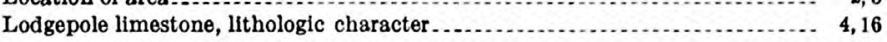

metamorphism of.................................................... 54

thickness ................

\section{$\mathrm{M}$}

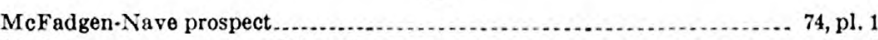

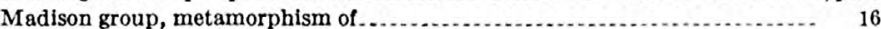

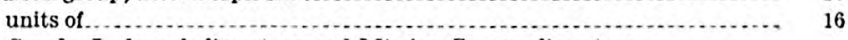
See also Lodgepole limestone and Mission Canyon limestone.

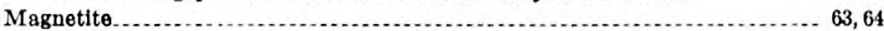
See also mine descriptions.

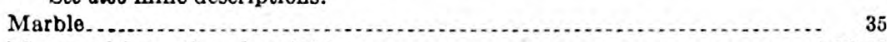

Maywood formation, description . . . . . . . . . . . . . . . . . . . $\ldots \ldots \ldots \ldots \ldots \ldots$

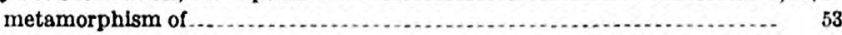

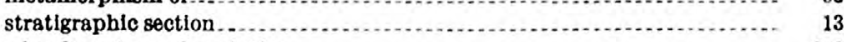

Meagher limestone, description........................................... 8

gold deposits in
lithologic character. $\ldots \ldots \ldots \ldots$

lithologic character. 
Meagher limestone-Continued Ore deposit in... See also mine descriptions.

Page stratigraphic sections. thickness.

Mesozoic rocks, metamorphism of

Metamorphism, additive of Elkhorn Mountains volcanics of Mesozoic rocks.

of Paleozoic rocks..

of Precambrian rocks thermal.

Mineral deposits, contact metamorphic deposits metallic. . nonmetallic..

pipelike breccia deposits

placer.

replacement deposits in carbonate rocks.

veins...

Minerals, production

Mines, descriptions of . -

Miocene age, tuffaceous sediments of

Mission Canyon limestone, breccia in

lithologic character.

metamorphism of

ore minerals in

stocks in....

stratigraphic sections.

surface expression

thickness.

Mississippian system. See Lodgepole limestone, Mission Canyon limestone, and Amsden formation.

Monzonite, chemical analysis.

See also Quartz monzonito.

Morrison formation, description.

lithologic character.

stratigraphic section

thickness.

\section{N}

Ned claim. See Parker group of claims.

Nygaard, E. A., chemical analyses by.

$34,47,49,50$

0

Oligocene age, tuffaceous sediments of ....

Paleozoic rocks, metamorphism of. .

$53-54$

Palmer, A. R., quoted

Parker group of claims........................................... $65-66,77$, pl. 2

Park shale, description...

lithologic character...

metamorphism of ...

stratigraphic sections

thickness.

assover claim

Peck, R. E., fossils identified by

$$
\text { quoted }
$$

Pediment.

Pediment veneers

Pennsylvanian system, rocks of. See Quadrant formation.

Permian system, boundary between Jurassic system and

Permian system, rocks of. See Phosphoria formation.

Phenocrysts, feldspar hornblende.

plagioclase..

pyroxene...

quartz.-

Phosphate rock.

Phosphoria formation, description

lithologic character.

metamorphism of...

stratigraphic sections of

thickness...

Physiographic units of the area.

10

4,10

4,10
53
10

4,10

$65,74, \mathrm{pl} .2$

37

60, 61

Phim dolomite, description.

fossils in..

lithologic character.

metamorphism of
Pilgrim dolomite-Continued

mineral deposits in.

See also Elkhorn Mine and Keene Mine.

Page

stratigraphic section.

63,67

thickness...

11,12

Pittsmont clalm

$4,10-11$

Placer deposits.

$63,69-70, \mathrm{pl} .1$

Placer deposits $\ldots \ldots \ldots \ldots \ldots \ldots \ldots \ldots \ldots \ldots \ldots \ldots$
Plutons, description

time of emplacement.

Poe Park, stratigraphic section..

Precambrian rocks, description. .

metamorphism of.

Previous investigations.

Prichard, G. E., with Richards, P. W., quoted.

Prospecting, suggestions for.

Q

Quadrant formation, lithologic character.

metamorphism of ...

stratigraphic section.

thickness...

Quartz diorite, felsic, chemical analysis

Quartz-diorite porphyry, chemical analysis .

Quartzite.

45

36
$5-6$

$2-53$
$2-3$

38

66

chemical analysis

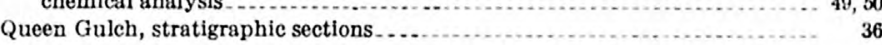

R

Radersburg Pass, stratigrapbic section.............................. 36

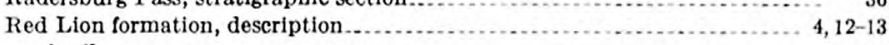

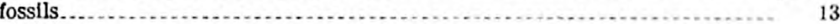

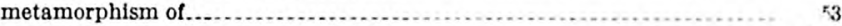

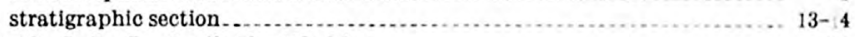

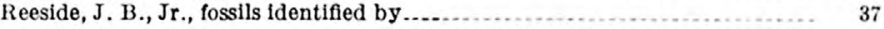

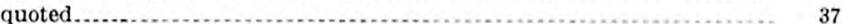

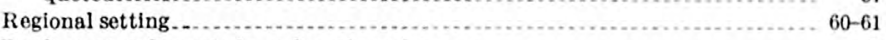

Replacement deposits in carbonate rocks . . . . . . . . . . . . . . . . . .

Rhyolite flow, of uncertain age . .................... 42

Richards, P. W., and Prichard, G. E., quoted ........................... 38

Rothfus iron mine .......................................... 65-66, 77, pl. 2

Ruppel, E. T., stratigraphic sections measured by .............. 16, 18-19, 20-21

S

Sagebrush Park stock, chemical analysis of rocks.......................... 50

description . . . . . .

quantitative description of rocks...

Siliceous mudstone and sandstone unit of Colorado formation, source of materials.

Sill, albitization...

51

Sills, folding of

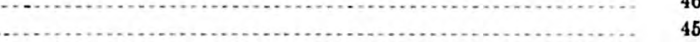

See also mine descriptions.

Silver Bell. See Parker group of claims.

Silver Hill claim. See J and F No. 1 claim.

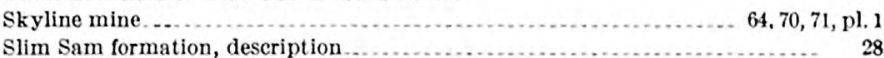

fossils...

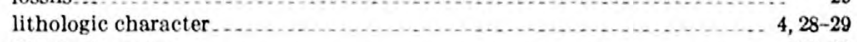

lithologic units . . . . . . . . . . .

stratigraphic sections........... 29-31

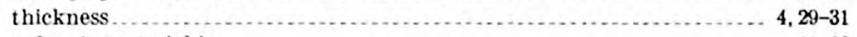

volcanic material in ............................................ 29

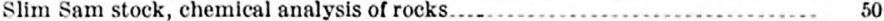

description...................................................... 50

quantitative description of rocks ................................ 51

Sohn, I. G., fossils identified by ............... 37

Sourdough mine. See Golden Curry mine.

Spar mine .............................................. $65-66.67,74,75, \mathrm{pl} .2$

Spokane shale, fossil algae in .........................................

lithologic character .............................

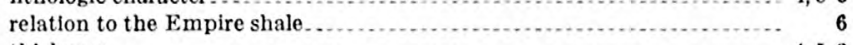

thickness. . . . .

Stocks, Black Butte stock........................................... 46-47

Cemetery Ridge stock ..................................... 47

diorite porphyry stock ............................................... 48

fine-grained diorite stock .................................... 47

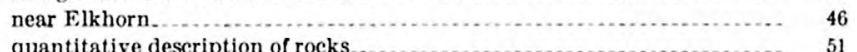

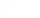

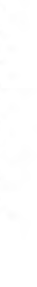


Stocks-Continued

Sagebrush Park stock

Slim Sam stock...

Turnley Ridge stock

Stone, R. W., quoted.

Stratigraphic control of ore deposits See also mine descriptions.

Stratigraphy, summary of..

Structural control of ore deposits See also mine descriptions.

Structural control of topography

Structure, anticline

dome

faults.

folds

general feature

syncline...

Summit claim...

Swift formation, fossils

lithologic character.

metamorphism of.

thickness.

Swissmont claim.

$63,69-70$, pl. 1

$\mathrm{T}$

Tacoma Gulch fault

$52,58,59$

Tacoma mine

$65,72, \mathrm{pl}, 2$

Tectonic history.

Tertiary system, rocks of

Three Forks shale, fossils

lithologic character.

metamorphism.

Page

50

50
50

48
73

3, 64, 65, 66

$63,64,65,66$

mineral deposits in

thickness

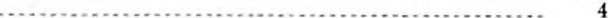

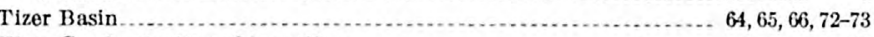

Tizer Creek, stratigraphic section............................................ 36

Tourmaline, black ................................................. 50, 64

Tourmaline Queen mine ........................................... pl. 1

Trail Spring road, stratigraphic section . ........................... $7,8,9,14-15$

Transportation

Tuff, aeolian.

crystal.

crystal-lithic
Tuf-Continued

Page

in Elkhorn Mountains volcanics................................. 33, 34

lapilli.........

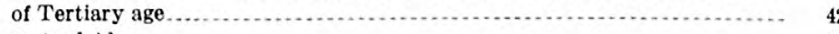

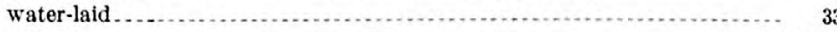

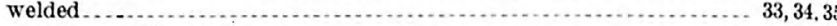

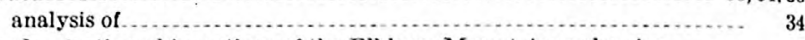

See also stratigraphic sections of the Elkhorn Mountains volcanics.

Turnley Ridge stock, chemical analysis of . ........................... 47

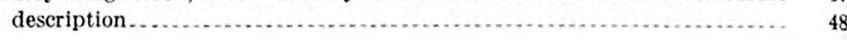

U

Unconformity, at base of Elkhorn Mountains volcanics. ........... 24, 29, 40, 55

at base of Oligocene rocks............................................. 32

between Jurassic and Cretaceous rocks.............................. 23

between Maywood and Red Lion formations......................... 12

between Permian and Jurassic rocks . . . . . . . . . . . . . . . . . . . . . . . 22, 23

indication of .............................................. 48

in Elkhorn Mountains volcanics............................... 32, 40,44

Union mine.

$63,69, \mathrm{pl} .1$

$\mathrm{V}$

Valley View claim. See J and F No. 1 claim.

Vegetation, in glaciated areas.

\section{W}

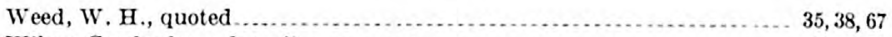

Wilson Creek placer deposit....................................... 73, pl. 1

Wolsey shale, description.......................................... 8

lithologic character . . . .

metamorphism of .................................................. 53

stratigraphic section.......................................... 8

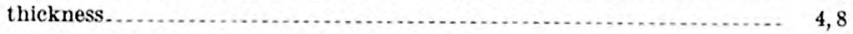

Y

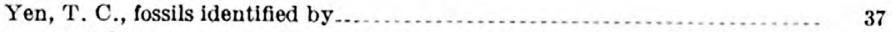

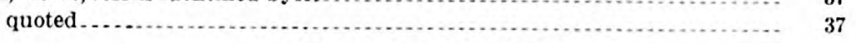

Zinc.

See also mine descriptions. 